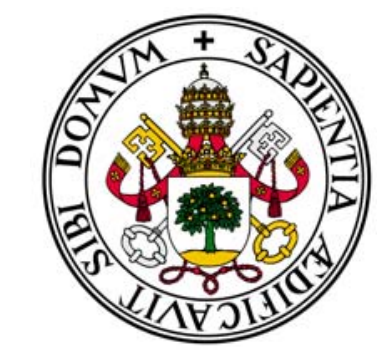

UNIVERSIDAD DE VALLADOLID

Facultad de Medicina

Departamento de Bioquímica y Biología Molecular y Fisiología

Instituto de Biología y Genética Molecular (IBGM)

\title{
El papel de las células dendríticas en la respuesta a patrones moleculares de la pared de hongos y a la sobrecarga de células apoptóticas
}

Memoria de tesis presentada por:

Etzel Balbilin Hugo Gil

Para optar al grado de Doctor por la Universidad de Valladolid

Dirigida por:

Mariano Sánchez Crespo

Mª Nieves Fernández García

Valladolid, 2013 

| Índice 
Abreviaturas

Resumen

Introducción

1. Sistema Inmunitario

- Inmunidad Innata y Adaptativa

- Los leucocitos Polimorfonucleares

- Células dendríticas y macrófagos

2. Receptores de reconocimiento de patrones 16

- Receptores tipo Toll

- Receptores de lectina tipo C

3. Patrones moleculares asociados a patógenos

4. Reconocimiento de células apoptóticas

- Receptores scanvenger

- Receptores de colectinas, petraxinas y complemento

- Receptores con actividad tirosina quinasa

- Papel de la esfigosina-1-fosfato

5. Metabolitos del ácido araquidónico 29

6. Producción de citoquinas $\quad 30$

- Interleuquina 10 (IL-10) 31

- Interleuquina 12 (IL-12 p70) 31

- Interleuquina 23 (IL-23) 32

- Regulación de la producción de IL-12 p70 e IL-23 32

7. Regulación transcripcional 33

- CREB y su coactivadores 34

- La homeoproteína PBX1 36

- Actividad de PPAR- $\gamma$

$\begin{array}{ll}\text { Objetivos } & 39\end{array}$

Materiales y métodos $\quad 42$

1. Aislamiento y cultivo de las células 43

1.1. Aislamiento de leucocitos mononucleares y polimorfonucleares a partir de sangre periférica 43

- Separación de las células mononucleares 43

- Diferenciación de células dendríticas 44

- Diferenciación de Macrófagos 45

- Obtención de leucocitos polimorfonucleares 45 
1.2 Células Jurkat 46

2. Preparación de los distintos estímulos 46

2.1 Inducción de la apoptosis y necrosis celular en células Jurkat y Polimorfonucleares 46

2.2 Preparación de partículas de zymosan A $\quad 47$

- Unión de C3bi a las partículas de zymosan (opzonización) 47

2.3 Obtención de suero anti-ovoalbúmina $\quad 47$

- Preparación de inmunocomplejos de lgG-ovo-albúmina 47

3. Citometría de flujo $\quad 48$

3.1 Ensayo de expresión de receptores en la membrana plasmática de células mononucleares $\quad 48$

3.2 Análisis de las células apoptóticas y necróticas 48

3.3 Detención de cuerpos lipídicos $\quad 49$

4. Determinación de los niveles de secreción de citoquinas y de otros mediadores antiinflamatorios $\quad 50$

5. Inmunodetencción de proteínas $\quad \mathbf{5 0}$

5.1 Obtención de los lisados celulares $\quad 50$

5.2. Separación de extractos nucleares y citosólicos 51

5.3 Electroforesis en geles de acrilamida e inmunodetención de proteínas 51

6. Ensayo de liberación de ácido araquidónico 52

7. Analisis a nivel transcripcional 52

7.1 Extracción del ARN total 53

7.2 Síntesis del ADN complementario 53

7.3 PCR cuantitativa en tiempo real $\quad 54$

7.4 Análisis de la expresión génica mediante PCR 54

8. Cuantificación de la esfingosina-1-fosfato liberada de las células apoptóticas 56

8.1 Extracción de esfingosina-1-fosfato 56

8.2 Cuantificación por espectrometría de masas $\quad 57$

9. Expresión de los datos a nivel estadístico 57

Resultados $\quad 59$

1. Caracterización de los receptores implicados en el reconocimiento de los patrones fúngicos en células mononucleares humanas $\quad 60$

- Cuantificación de la expresión de los receptores por RT-PCR 61

2. Análisis por citometría de flujo para detectar la externalización de la fosfatidilserina y el aumento de permeabilidad de la membrana en las células apoptóticas 62

2.1 Inducción de apoptosis con estaurosporina 64

2.2 Inducción de apoptosis en otra estirpe celular 64 
3. Efecto de la estimulación de factores bacterianos y de la pared de hongos sobre la producción de citoquinas en células dendríticas

3.1 Efecto de la adición de células Jurkat 66

3.2 Liberación mediadores anti-inflamatorios $\quad 68$

4. El papel de las opsoninas del suero sobre el reconocimiento de las células apoptóticas $\quad 69$

5. Regulación transcripcional de il-10 durante el reconocimiento de las células apoptóticas $\quad \mathbf{7 0}$

5.1 Papel del co-activador CRTC2/TORC2 71

5.2 Interacción entre CRTC2/TORC2 y la proteína PBX1 72

5.3 CRTC2/TORC2 co-inmunoprecipita con PBX1 73

6. La posible participación del PPAR- $\gamma \quad 74$

6.1 Papel del PPAR- $\gamma \quad 75$

7. Formación de cuerpos lipídicos como efectores de la tolerancia inmune inducida durante el $\begin{array}{ll}\text { reconocimiento de células apoptóticas } & 76\end{array}$

8. Metabolismo del ácido araquidónico en células dendríticas en respuesta a las células $\begin{array}{ll}\text { apoptóticas } & 78\end{array}$

9. Liberación de esfingosina-1-fosfato por células apoptó-ticas 82

9.1 Efecto de la esfingosina-1-fosfato en la producción de IL-10 84

Discusión $\quad 88$

La expresión de los receptores de membrana de las células fagocíticas depende del proceso de diferenciación y de los componentes del medio 89

Las células Jurkat como modelo reproducible de células en apoptosis temprana

Efecto modulador de las células apoptóticas sobre la producción de citoquinas y mediadores inflamatorios inducida por zymosan y LPS

Mecanismos de la regulación transcripcional de il-10 implicados en el reconocimiento de células apoptóticas y hongos

Efecto de la esfingosina-1-fosfato liberada por células apoptóticas sobre la producción de IL-10 96

$\begin{array}{lr}\text { Conclusiones } & 99\end{array}$

$\begin{array}{ll}\text { Bibliografía } & 102\end{array}$

$\begin{array}{lll}\text { Anexol } & 114\end{array}$

Anexo II 118 

Abreviaturas 
Algunas abreviaturas y acrónimos empleados se han mantenido en la lengua inglesa:

AA: Ácido araquidónico

AC: Adenilato ciclasa

ACAMP: Patrones moleculares asociados a células apoptóticas

AP1: Activator protein-1

APC: Antigen presenting cell

BSA: Albumina de suero bovino

CA: Células apoptóticas

CARD9: Caspase recruitment domain-containing protein 9

CBP: CREB binding protein

CD: Células dendríticas

CLR: C type lectin receptor

COX: Cicloxigenasa

CR3: Receptor del complemento 3

CREB: Cyclic AMP regulatory element binding protein

CRD: Carbohidrate recognition domain

CRP: C reactive protein

CRTC/TORC2: $\quad$ Cyclic AMP-regulated transcriptional coactivator

CT: Cycle thresold

CTLD: C- type lectin-like domain

DAMP: Patrones moleculares asociados a daño

DAP12: DNAX-activating protein of $12 \mathrm{kDa}$

Dectin-1: DC-associated C-type lectin-1

ES: Error estandar

EP: Receptores de prostanoides de la serie $E$

FBS: Suero fetal bovino

Fc $\gamma$ R: Receptores FC gamma

FITC: Isocianato de Fluoresceína

GM-CSF: Factor estimulador de colonias de granulocitos

GPCR: G-protein-coupled receptors

GW9662: Antagonista del PPAR-y

HDAC: Histona deacetilasa

IC: Inmunocomplejos de IgG-ovo-albúmina

ICAM: Intercellular adhesion molecule

IFN: Interferón

IL-1 $\beta$ : Interleuquina 1 beta

IL-3: Interleuquina 3

IL-4: Interleuquina 4

IL-6: Interleuquina 6

IL-10: Interleuquina 10 
IL-12: Interleuquina 12

IL-17: Interleuquina 17

IL-21: Interleuquina 21

IL-22: Interleuquina 22

IL-23: Interleuquina 23

IP: loduro de propidio

ITAM: Immunoreceptor tyrosine-based activaction motif

IRAK: Interleukin-1 receptor-associated kinase

IRF: Factor regulador de interferón

JK: Células Jurkat

JKc: Jurkat tratadas con camptotecina

JKs: Jurkat tratadas con estaurosporina

LPR: Low-density lipoprotein receptor-related protein

LPS: Lipopolisacárido

LOX-1: Lectin-like oxidized low-density lipoprotein receptor 1

M-CSF: Factor estimulante de colonias de macrófagos

MFI: Intensidad media de fluorescencia

MyD88: Myeloid differentation primary response gene 88

NK: Natural Killer Cell

MØ: Macrófagos

MØSH: Macrófagos diferenciados con suero humano

MØM-CSF: Macrófagos diferenciados con M-CSF

MAPK: Mitogen-Activated Protein Kinases

MHC: Major histocompatibility complex

NcoR: Nuclear corepresor

NEMO: NF-kappa-B essential modulator

NFAT: Nuclear factor of activated T-cells

NF- $\mathrm{BB}$ : Factor nuclear $\mathrm{kB}$

PAMP: Patrones moleculares asociados a patógenos

PBX1: Pre-célula de leucemia -B homeobox 1

PE: Ficoeritrina

PGE $_{2}$ : Prostaglandina $\mathrm{E}_{2}$

PKA: cAMP-protein kinase $A$

PLA2: Fosfolipasa $A_{2}$

PMN: Polimorfosnucleares

PPAR- $\gamma$ : Peroxisome proliferator-activated receptor- $\gamma$

PRR: Receptores de reconocimiento de patrones

PS: Fosfatidilserina

PSR: Receptor de la fosfatidilserina

PXT3: Pentraxin 3

RAF1: v-raf-leukemia viral oncogen homolog 1 
RM: Receptor de manosa

S1P: Esfingosina-1-fosfato

SAP: Serum amyloid $P$

SH: Suero humano

SHi: Suero humano inactivado

SHn: Suero humano normal

SIK: Salt-inducible kinase

SYK: Spleen tyrosine kinase

TBL1: Transducin- $\beta$ like protein 1

TBLR1: TBL1-related 1

TBP: Proteína de unión a TATA box

TCR: Receptor de las células T

TGF- $\beta$ : Factor de crecimiento transformante beta

Th: Linfocito T colaborador (T Helper)

Th1: Respuesta inmune linfocitos T tipo 1

Th2: Respuesta immune linfocitos T tipo 2

Th17: Respuesta inmune linfocitos T productores IL-17

TIM: $T$ cell Immunoglobulin domain and mucin domain

TIR: Toll/interleukin-1 receptor

TIRAP: TIR domain-containing adapter protein

TNF- $\alpha$ : Tumor necrosis factor

TLR: Recetores tipo Toll

TRAF: TNF receptor associated factors

TRAM: TRIF-related adaptor molecule

Treg: Linfocito T regulador

TRIF: Domain-containing adaptor-inducing interferon $\beta$

TSP: Trombospodina

UPLC-QToF-MS: Ultraperformance liquid chromatography interfaced to a time-of-flight mass spectrometer 

Resumen 
La resolución de la respuesta inflamatoria depende en gran medida de las células fagocitarias que eliminan patógenos y restos de tejidos dañados e intervienen en el proceso de presentación de antígenos, por lo que constituyen un nexo fundamental entre la respuesta inmunitaria innata y la adaptativa. Las células dendríticas y los macrófagos, son las principales células presentadoras de antígeno, puesto que expresan receptores que reconocen un gran número de estructuras conservadas en los microorganismos denominadas patrones moleculares asociados a patógenos.

La eliminación de células apoptóticas por fagocitosis se considera un mecanismo que permite reducir el daño tisular durante la respuesta inflamatoria. Estas células exponen diversas moléculas en el exterior de su membrana que pueden ser reconocidas por receptores que intervienen en su eliminación y que, en principio, no desencadenan una respuesta inflamatoria. Curiosamente, alguno de estos receptores participa en el reconocimiento de patrones moleculares de hongos, lo que indica un posible paralelismo en las rutas de señalización. La caracterización de los mediadores químicos liberados durante el reconocimiento de células apoptóticas ha mostrado la predominancia de las citoquinas anti-inflamatorias frente a las proinflamatorias, con una alta producción de IL-10 y baja secreción de IL-12 p70, que conduce a la supresión de la respuesta inmune de tipo Th1. Curiosamente, este patrón de citoquinas es similar al observado durante las infecciones por hongos y puede conducir a que no se pueda controlar la infección.

En el presente estudio hemos observado que las células apoptóticas modulan positivamente la producción de IL-10 y reducen la liberación de IL-23 sin modificar la secreción de IL-12 p70. Este efecto se observa en presencia de zymosan, un extracto de la membrana de Saccharomyces cerevisiae compuesto preferentemente de $\beta$-glucanos que reproduce la estructura de la pared celular de los hongos, pero no cuando se utiliza lipopolisacárido bacteriano. En estudios previos se ha demostrado que CREB (CRE binding protein) es el principal regulador de la transcripción de IL-10 en colaboración con los coactivadores CBP (CREB binding protein) y CRTC2 (CREB regulated transcription coactivator), también denominado TORC2 (transducer of regulated CREB activity). En este estudio hemos identificado que un mecanismo similar de regulación transcripcional está implicado en la producción de IL-10 en respuesta a las células apoptóticas, en el que también interviene la proteína homeodominio PBX1 en un complejo supramolecular de alto orden. 
A la vista de los presentes resultados, la modulación por las células apoptóticas de la respuesta inflamatoria inducida por los patrones de hongos puede considerarse como un mecanismo regulador de la inflamación, pero con el riesgo asociado de poder bloquear la erradicación de patógenos. 



\section{Introducción}




\section{El sistema inmunitario}

\section{- Inmunidad innata y adaptativa}

La función del sistema inmune es la protección del organismo frente a las infecciones y al daño tisular inducido por agentes físicos o químicos, y el mantenimiento de la homeostasis en los tejidos. En el sistema inmune se distinguen dos componentes: el sistema inmune innato y el adaptativo. El sistema inmune innato es responsable de la respuesta inicial frente a la invasión por patógenos. Entre sus componentes destaca el papel funcional de las células fagocitarias (células dendríticas, macrófagos, neutrófilos y células Natural Killer), que se acumulan en los focos inflamatorios para la eliminación de los patógenos y la captura de antígenos, y su posterior transferencia mediante las moléculas del complejo de histocompatibilidad (MHC, major histocompatibility complex) a los linfocitos $\mathrm{T}$, para dar inicio a la denominada fase adaptativa de la respuesta inmune (Figura 1). En esta conexión entre la fase innata y la adaptativa de la inmunidad tienen un papel esencial las células dendríticas $(C D)$ y los macrófagos ( $M \varnothing)$, además de las citoquinas por su capacidad para polarizar la respuesta inmune. Los elementos más importantes del sistema inmune adaptativo son los linfocitos T y B. La activación de los linfocitos T depende de la presentación de antígenos en las moléculas del MHC al receptor de las células $T$ vírgenes ( $T$ naive) y de las moléculas coestimuladoras. Los linfocitos $T$ son un componente fundamental de la inmunidad adaptativa, puesto que además de su propia respuesta, contribuyen a la activación de los linfocitos B (Figuras 1 y 2 [panel inferior derecho]).

La captación de antígenos se realiza mediante moléculas denominadas receptores de reconocimiento de patrones (PRR pattern recognition receptor) que se expresan en la membrana plasmática, vesículas endosómicas y el citoplasma de las células presentadoras de antígenos (APC, antigen presenting cell). Estos receptores reconocen estructuras de los microorganismos conservadas a lo largo del proceso evolutivo que se denominan patrones moleculares asociados a patógenos (PAMP pathogen associated molecular patters) y también estructuras generadas durante el daño tisular denominadas patrones moleculares asociado a daño (DAMP, danger associated molecular patters) (Figura 2). La interacción de los PAMPs con su PRR es fundamental para la discriminación entre lo propio y no propio, y el progreso de la inmunidad adaptativa. 


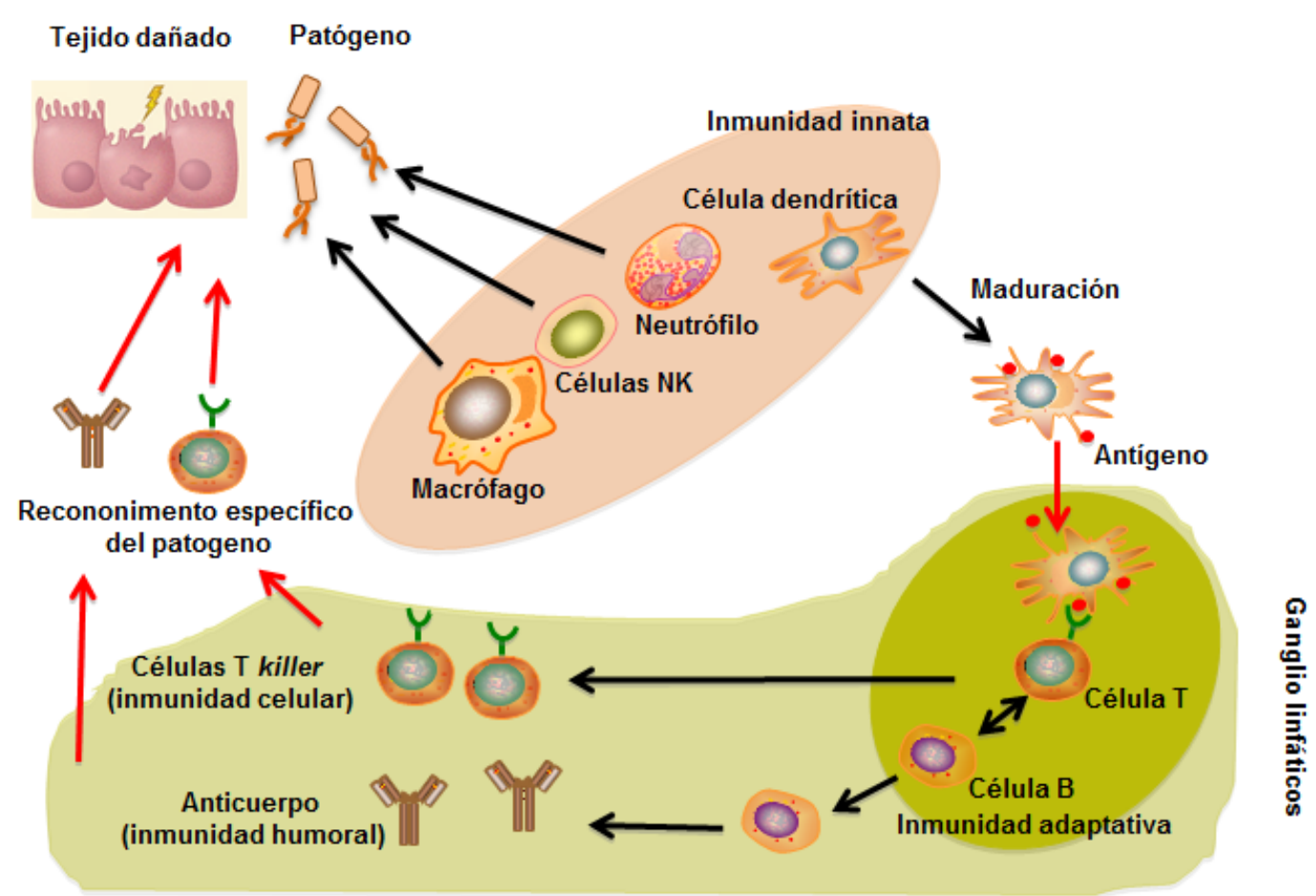

Figura 1: Interacción entre la inmunidad innata y adaptativa. La inmunidad innata es la primera línea de defensa frente a la infección y al daño tisular. En la inmunidad innata las células presentadoras de antígeno procesan el antígeno y sufren un proceso de maduración que incluye secreción de citoquinas y la posterior migración a los ganglios linfáticos donde se pone en marcha la inmunidad adaptativa mediante la activación de los linfocitos T y B. La inmunidad innata permite el reconocimiento de los patógenos de forma genérica sin otorgar inmunidad duradera, por lo que es una respuesta rápida e inespecífica. Contrariamente, la respuesta de la inmunidad adaptativa es tardía pero específica y activa el mecanismo de memoria inmunológica NK: natural killer. Adaptada de Akira, 2011.

El reconocimiento de patógenos permite a las CD secretar citoquinas pro-inflamatorias y la posterior diferenciación de las células de tipo $T$ colaboradoras ( $T$ Helper, Th) a células efectoras de tipo Th1, Th2, Th17, supresoras y reguladoras (Treg) (Figura 2). Las células Th1 y Th2 contribuyen a la eliminación de patógenos extracelulares e intracelulares y las Th17 y Treg están implicadas en respuestas autoinmunes e inmunosupresoras, respectivamente. En otras palabras, las células Th pueden originar respuestas inflamatorias y anti-inflamatorias, e incluso un estado de tolerancia (Banchereau et al., 2000). 


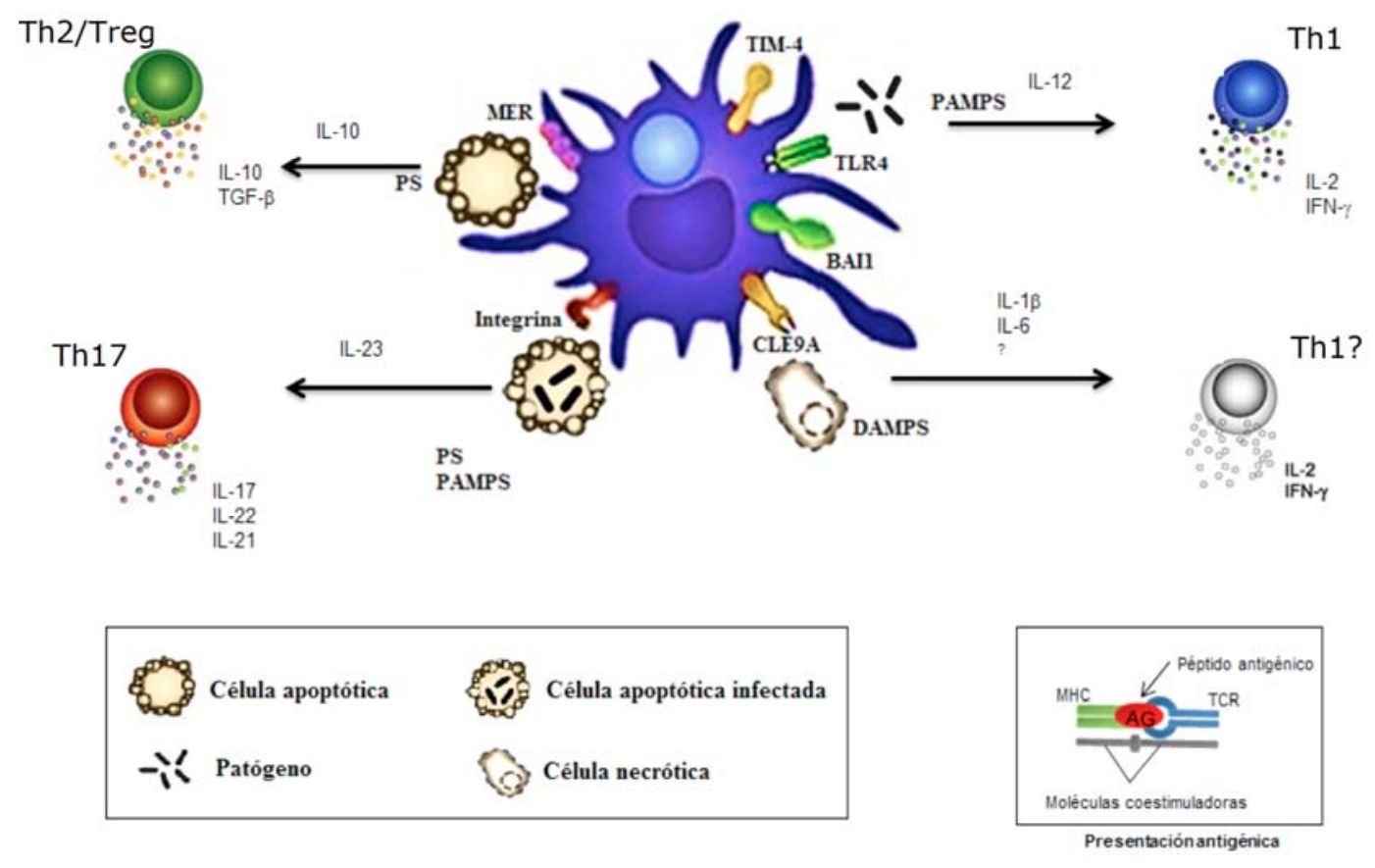

Figura 2: Reconocimiento de patógenos y células que sufren muerte celular. La fagocitosis de células apoptóticas induce la síntesis de citoquinas inmunoreguladoras a través del reconocimiento de moléculas como la fosfatidiserina (PS) (panel superior izquierdo). La diferenciación a células Th17 se ha descrito durante el reconocimiento de células apoptóticas mediante la participación de IL-23, IL-6 y TGF- $\beta$, y se ha observado durante el reconocimiento de células apoptóticas infectadas (panel inferior izquierdo). En el panel superior derecho se ilustra el reconocimiento de algunos patógenos mediante la activación de PRR, que dependiendo del patógeno, pueden inducir la secreción de citoquinas pro-inflamatorias y polarizar las células T hacia Th1. En el reconocimiento de células necróticas interviene el receptor CLE9a y la secreción de la citoquina inflamatoria IL-1 $\beta$ (Green et al; 2009 y Zhang et al., 2012). La presentación del antígeno al linfocito T virgen es mediada por péptidos unidos a moléculas del MHC presentados al TCR en cooperación con moléculas coestimuladoras, lo que permite la activación del linfocito y el inicio de la inmunidad adaptativa. Adaptada de Brereton y Blander, 2010.

\section{- Los leucocitos polimorfonucleares}

Los polimorfonucleares (PMN) son los leucocitos que migran con mayor rapidez a los focos infecciosos. Constituyen más del $50 \%$ de los leucocitos totales y más del $90 \%$ de los fagocitos de la sangre periférica. Tienen una vida corta, se producen en grandes cantidades durante las respuestas inmunitarias y mueren por apoptosis unas pocas horas después de migrar hacia los focos infecciosos y de cumplir su función como células fagocíticas. Además, tienen una capacidad limitada de actividad biosintética, debido a su baja capacidad de iniciar la transcripción génica (Kobayashi y De Leo., 2009). Sus funciones principales son la fagocitosis y la liberación de enzimas hidrolíticas y de especies reactivas de oxigeno (ROI, reactive oxigen intermediates), lo que explica su gran actividad antimicrobiana. Sin embargo, esta capacidad 
puede ocasionar daño tisular incluso en zonas alejadas del foco infeccioso. Los PMN se renuevan continuamente existiendo un equilibrio entre su ritmo de producción y su eliminación.

\section{- Células dendríticas y macrófagos}

La migración de los PMN a los focos inflamatorios es seguida por la llegada de monocitos, que a su vez, pueden diferenciarse en $M \varnothing$ y $C D$ en respuesta a factores de crecimiento y citoquinas (Geissmann et al., 2010 [1]). Entre los factores que polarizan la diferenciación de $M \varnothing$ se encuentran el factor estimulante de colonias de $M \varnothing$ (M-CSF) y la interleuquina 3 (IL-3) (Banchereau et al., 2000), y entre los factores de crecimiento que permiten la diferenciación a $C D$ se incluyen el factor estimulador de colonias de granulocitos (GM-CSF), el factor de crecimiento transformante $\beta$ (TGF- $\beta$ ) y la interleuquina 4 (IL-4).

Una característica importante de las CD es la morfología de su membrana en el estado inmaduro, donde se observan prolongaciones (dendritas) que les permiten tener una gran capacidad para la captación, procesamiento, transporte y presentación de antígenos a los linfocitos T (Steinman y Cohn, 1973; Banchereau et al., 2000). El proceso de maduración produce pérdida de la capacidad de adherencia, disminución de la capacidad fagocitaria, adquisición de motilidad, translocación a la membrana plasmática de moléculas MHC de clase II, secreción de citoquinas y migración hacia los ganglios linfáticos.

Los M $\varnothing$ poseen una alta capacidad para la degradación de los antígenos (Banchereau et al., 2000), pero muestran una menor capacidad de presentación de antígenos que las CD. En condiciones basales los $M \varnothing$ contribuyen al mantenimiento de la homeostasis de los tejidos mediante la eliminación de las células apoptóticas (CA), la producción de factores de crecimiento y la remodelación y reparación de tejidos (Geissmann et al., 2010 [1]; Gordon y Taylor, 2005).

Estudios experimentales han permitido identificar citoquinas y productos bacterianos que controlan la función efectora de los $M \varnothing$, de este modo se han designado como $M \varnothing$ de tipo 1 (M1) los que anteriormente se denominaban "activados", es decir, aquéllos que se diferencian por estímulos pro-inflamatorios como IFN- $\gamma$ y el lipopolisacárido bacteriano (LPS). Este tipo de células posee capacidad microbicida (Geissmann et al., 2010 [2]) y tumoricida, y secreta grandes cantidades de citoquinas y mediadores pro-inflamatorios (Mosser y Edwards, 2008), por lo que favorecen las respuestas de tipo Th1 (Martínez et al., 2008). La designación de los M $\varnothing$ de tipo 2 (M2), o M $\varnothing$ activados alternativamente, se introdujo para incluir a los que se polarizan tras la estimulación con IL-4 o IL-13 (M2a), inmunocomplejos combinados con IL-1ß, LPS (M2b), IL- 
10, TGF- $\beta$ o glucocorticoides (M2c) (Martínez et al, 2008). Los M2 se asocian a respuestas de tipo Th2 y su actividad funcional a la resolución de la inflamación por fagocitosis, la síntesis de factores tróficos y la disminución de citoquinas pro-inflamatorias (Martínez et al., 2008).

De manera general, la activación de los $M \varnothing$ se puede clasificar en varios estadios (Figura 3) el primero es la diferenciación dirigida por factores de crecimientos, como M-CSF, el segundo la estimulación por citoquinas que favorecen una activación clásica o alternativa, y el tercero la respuesta dependiente de los estímulos locales transmitidos por receptores tipo Toll (TLR, Toll-like receptor) o análogos (Gordon y Martínez, 2010).

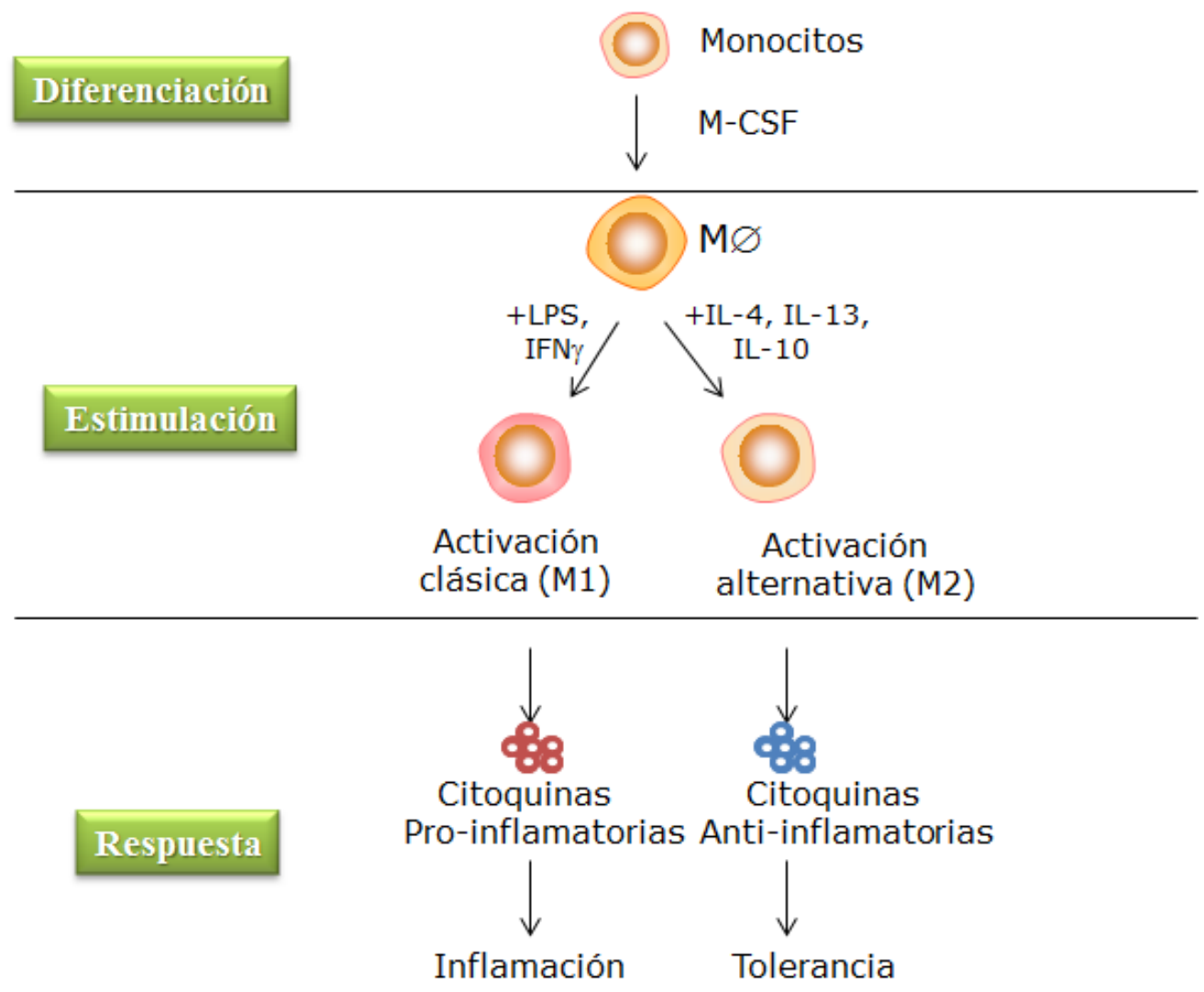

Figura 3: Polarización clásica y alternativa de la diferenciación de $M \varnothing$. La activación clásica puede ser inducida por mediadores inflamatorios derivados de la respuesta Th1. La activación alternativa se produce en respuesta a mediadores inductores de la respuesta Th2. La activación clásica contribuye a la respuesta inflamatoria, mientras que la alternativa se asocia con un estado de tolerancia. Adaptada de Dall'Asta et al., 2012.

\section{Receptores de reconocimiento de patrones}

La teoría de los patrones de reconocimiento propuesta por Janeway en 1989, permitió superar el esquema de funcionamiento del sistema inmune, que hasta entonces sólo había tenido en cuenta la distinción entre lo propio y no propio. Al identificar la función de los PRR, 
integró los concepto de la inmunidad innata y adaptativa, y postuló el papel de los PRR en la iniciación de la respuesta inmune y la activación de la inmunidad adaptativa (Medzhitov, 2009). Los PRR se codifican en la línea germinal y tienen una alta especificidad para el reconocimiento de las estructuras conservadas en los microorganismos, los PAMP (Medzhitov, 2007). Estos receptores se expresan, principalmente, en la membrana plasmática y vesículas endosómicas, e intervienen en la fagocitosis, la activación de rutas de señalización pro-inflamatorias, la producción de citoquinas y la inducción de apoptosis (Janeway et al., 2002). Uno de los modelos mejor estudiados es la respuesta a la infección por hongos, donde intervienen receptores tipo Toll y receptores con dominios de lectina de tipo C (CLR, C type lectin receptor) (Brown, 2010; Netea et al., 2008; Takeuchi et al., 2010; Romani, 2011).

\section{- Receptores de tipo Toll}

Esta clase de receptores son los mejores caracterizados en mamíferos en donde se han identificado diez miembros en humanos y trece en ratón (Takeuchi y Akira, 2010). Los receptores del uno al nueve están conservados en ambas especies (Brereton y Blander, 2010; Jeong y Lee, 2011). Los TLR son glicoproteínas transmembrana en cuya estructura se distingue un extremo $\mathrm{N}$-terminal en la porción extracelular con secuencias repetidas ricas en motivos de leucina (LRR, leucine rich repeat), implicada en el reconocimiento de patógenos, y un extremo C-terminal en la porción intracelular homologo a los receptores de IL-1, denominado TIR (Toll/interleukin-1 receptor), que interviene en la señalización celular (Akira, 2011 y Ishii et al., 2008). Algunos TLR se encuentran asociados a la membrana (TLR1,2,4,5,y 6) y otros en compartimientos intracelulares (TLR3,7,8,9 y 10). Un mismo receptor puede reconocer distintos ligandos, entre los que se incluyen lipoproteínas y mananos (TLR2/TLR6), ARN de doble hebra (TLR3), LPS (TLR4), flagelina (TLR5), ARN de hebra sencilla (TLR7), oligonucleotidos rico en G (TLR8), ADN rico en CpG (TLR9) y profilina (TLR11) (Ishii et al., 2008).

La unión del ligando permite la formación de homo o heterodímeros entre los TLR y el reclutamiento de moléculas adaptadoras. Existen dos vías de señalización que dependen de la interacción del dominio TIR con proteínas adaptadoras como MyD88 (myeloid differentation primary response gene 88) (Takeuchi y Akira, 2010; Ishii et al., 2008) y TRIF (domain-containing adaptor-inducing interferon $\beta$ ). La señal a través de MyD88 requiere la unión previa del adaptador Mal/TIRAP (MyD88-adapter-like protein/TIR domain-containing adapter protein) al dominio TIR, y permite la activación de las quinasas del complejo IKK y las MAPK. Esto permite 
la activación de los factores de transcripción de las familia NF-kB (nuclear factor $\mathrm{kB}$ ) y AP1 (activator protein-1). Esta vía de señalización no es utilizada por TLR3. TLR3 y TLR4 reclutan las moléculas adaptadoras TRAM (TRIF-related adaptor molecule) y TRIF, que conducen a la activación de IRF3 y a la producción de IFN-ß. (Akira, 2011; Akira y Takeda, 2004) (Figura 4). La activación de los factores de transcripción mencionados permite la expresión de genes implicados en la respuesta inflamatoria para la producción de citoquinas, quimioquinas e interferon (Janeway et al., 2002; Takeuchi y Akira, 2010, Akira, 2011; Akira y Takeda, 2004).

El reconocimiento de hongos por los TLR se produce principalmente por TLR2, TLR4 y TLR9 (Brown, 2010, Netea et al., 2008; Romani et al., 2011). Estos receptores reconocen componentes de hongos como $\beta$-glucanos, fosfolipomananos, mananos y ADN (Dillon et al., 2006; Romani et al., 2011; Netea et al., 2008).

TLR2 forma heterodímeros con otros TLR, específicamente TLR1 y TLR6 (Figura 4), y colabora con otros receptores como dectin-1 (DC-associated C-type lectin-1), un receptor de la familia de C-lectinas, para el reconocimiento de $\beta$-glucanos (Takeda y Akira, 2005). Sus ligandos son distintos productos bacterianos, fúngicos y parasitarios (Jeong y Lee, 2011; Janeway et al., 2002; Takeda y Akira, 2005).

TLR4 puede reconocer además del LPS, el polisacáridos de hongos. El reconocimiento del LPS depende de su interacción con varias proteínas que forman un complejo entre la proteína de unión a LPS (LBP), CD14 una proteína anclada a la membrana celular a través de glicosilfosfatidilinositol (GPI), y MD-2, una proteína que se asocia no covalentemente a TLR4 (Lu et al., 2008; Jeong y Lee 2011) (Figura 4). La captación del LPS por CD14 facilita la activación de TLR4 induciendo la producción de mediadores pro-inflamatorios.

TLR9 actúa a nivel intracelular en endosomas y lisosomas tras la lisis de los patógenos (Janeway et al., 2002). El ADN bacteriano y fúngico contiene pocos motivos metilados de CpG en comparación con el ADN humano, siendo esta diferencia la que permite el reconocimiento del ADN de estos microorganismos por TLR9 (Takeda y Akira, 2005; Netea et al., 2008). 


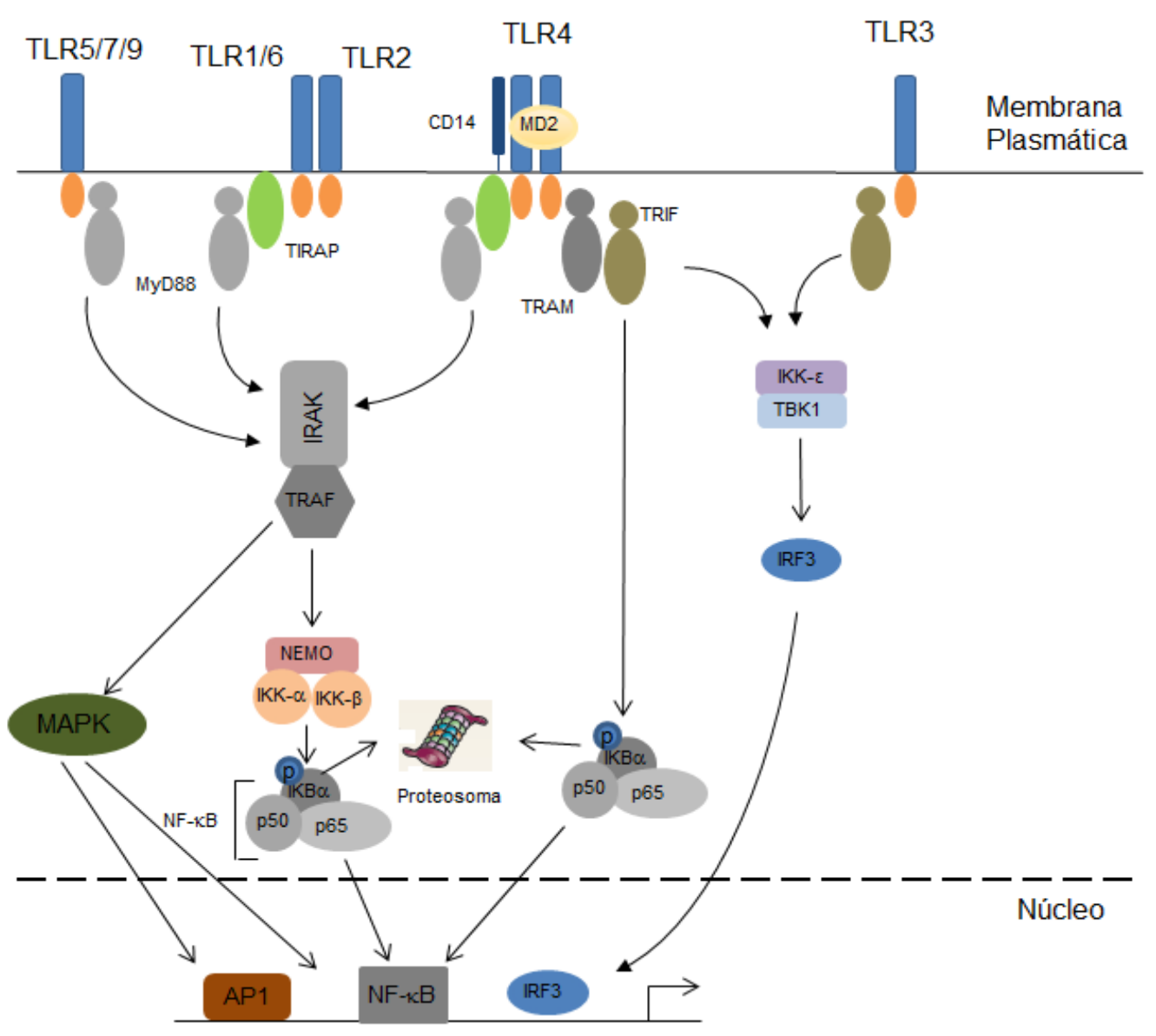

Figura 4: Señales dependientes de MyD88 y TRIF. TIRAP recluta a MyD88 y activa IRAK1, TRAF6 y el complejo IKK (NEMO/IKKa/IKKß) que fosforila I $\mathrm{KB} \alpha$ y promueve su degradación. Esto permite la translocación al núcleo de NF-KB. La cascada de señalización por MAPK también activa NF-KB y AP1. El adaptador TRAM es específico de TLR4 y media la ruta dependiente de TRIF. La señal por TLR3 y TLR4 permite la activación del IRF3 y la inducción del IFN- $\beta$. TLR3, TLR7, TLR8 Y TLR9 son receptores intracelulares expresados en endosomas. Adaptada de Akira y Takeda; 2004.

\section{- Receptores de lectina tipo C}

Los receptores de lectina tipo $\mathrm{C}$ son proteínas transmembrana que contienen al menos un dominio de lectina tipo C (CTLD, C-type lectin-like domain). Inicialmente se describieron como proteínas de unión a carbohidratos dependientes de $\mathrm{Ca}^{2+}$ para diferenciarlas de otras lectinas. El sitio de unión del ligando se denomina dominio de reconocimiento de carbohidratos (CRD, carbohidrate recognition domain) (Drickamer, 1988). Sin embargo, la identificación de CRD en otras proteínas demostró que no todos los CLR unen carbohidratos, e incluso pueden no precisar $\mathrm{Ca}^{2+}$, por lo que se introdujo el término más genérico de CTLD (Drickamer, 1999; Weis et al., 1998). La clasificación inicial incluía siete grupos de CLR en base a los dominios proteicos y a la filogenia. Sin embargo, los análisis de secuenciación en genomas de vertebrados han permitido añadir a la clasificación diez nuevos grupos hasta alcanzar un total de 17 grupos 
(Zelensky y Gready, 2005). Estos receptores se han implicados en la adhesión célula-célula y en el reconocimiento antigénico de patógenos y CA (Drickamer, 1999; Cambi y Figdor, 2009), siendo especialmente eficaces en el reconocimiento de patrones de hongos (Romani, 2011).

Los CLRs se pueden encontrar en forma soluble, como la lectina de unión a manosa (MBL, mannose-binding lectin) o las proteínas del surfactante pulmonar A y D (SP-A y SP-D), 0 como proteínas transmembrana las cuales se subdividen en dos grupos en función de la localización de su extremo N-terminal. Las del grupo I se caracterizan por presentar su extremo $\mathrm{N}$-terminal en el exterior celular con varios CTLD, como el receptor de manosa (RM o CD206). Las del grupo II pertenecen a la familia de receptores de asialoglicoproteínas, contienen su extremo N-terminal en el interior celular y se subdividen en otras dos subfamilias, la subfamilia DCIR (DC inmunoreceptor) que depende de $\mathrm{Ca}^{2+}$ para la unión del ligando, y la subfamilia que incluye dectin-1 cuya función es independiente de $\mathrm{Ca}^{2+}$ (Geijtenbeek y Gringhuis, 2009). La mayoría de los CLRs reconocen patrones de hongos y participan en la inducción de la respuesta de la inmunidad innata y adaptativa, como el RM, dectin-1, dectin-2 y DC-SIGN (dendritic cellspecific ICAM-3-grabbing non-integrin) (Romani, 2011).

En el caso de dectin-1 la señalización se produce a través de los dominios citoplasmáticos tipo ITAM (immunoreceptor tyrosine-based activaction motif) o hemITAM. En cambio, la señalización por dectin 2 requiere la cooperación con otros receptores, como TLR2, 0 adaptadores con dominios ITAM, como la cadena $\gamma$ del receptor Fc (FcR $\gamma$ ) y DAP12 (DNAXactivating protein of $12 \mathrm{kDa}$ ) (Takeuchi y Akira, 2010) (Figura 5). La señal por estos dos receptores precisa, en primer lugar, la fosforilación de las tirosinas del dominio ITAM por quinasas de la familia Src, lo que permite la unión de la tirosina quinasa SYK (spleen tyrosine kinase) mediante los dominios de homología Src2 (SH2) a las tirosinas fosforiladas y la posterior activación de las MAPK, y factores de transcripción de las familias NFAT (nuclear factor of

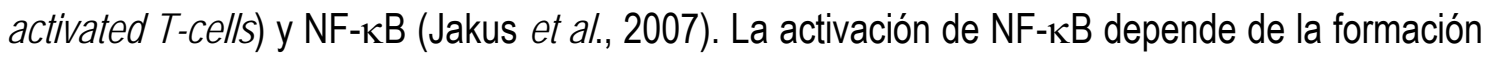
del complejo que incluye CARD9 (caspase recruitment domain- containig protein 9), Bcl10 (B cell lymphoma 10) y Malt1 (mucosa-associated lymphoid tissue lymphoma translocation protein1) (Hardison y Brown, 2012, Takeuchi y Akira 2010; Romani, 2011; Kerrigan y Brown, 2011). La via de señalización por DC-SIGN ocurre a través de la quinasa RAF1 (v-raf-leukemia viral oncogen homolog 1), que a su vez es utilizada por dectin-1 de manera independiente de SYK (Romani, 2011; Geijtenbeek y Gringhuis, 2009). La activación de SYK permite también la formación especies reactivas de oxigeno implicadas en la activación del inflamasoma NLRP3 (NOD-LRRand pyrin domain-containing 3) (Romani, 2011) (Figura 5). 


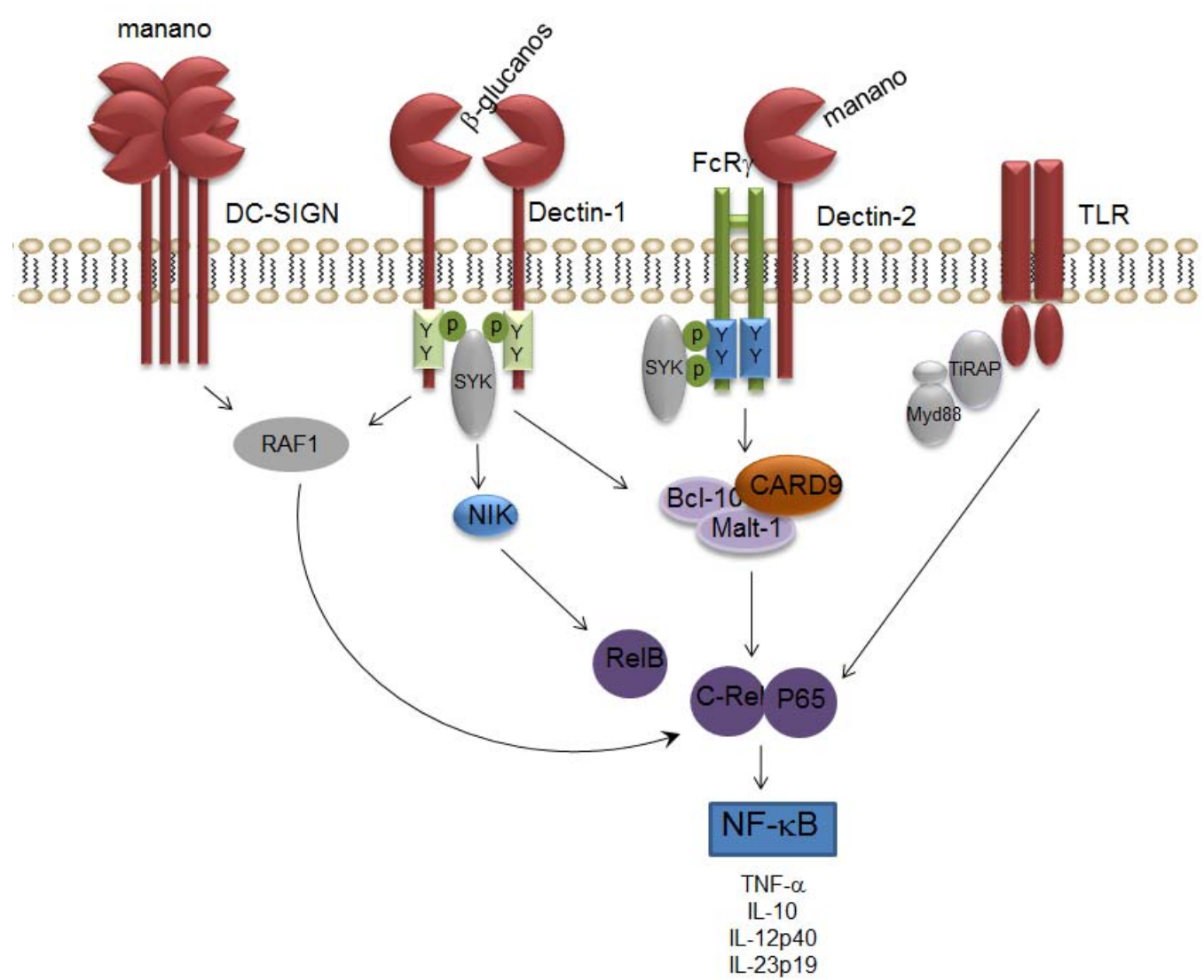

Figura 5: Vías de señalización de CLR y otros PRR que median la activación de NF-KB tras el reconocimiento de patrones moleculares de hongos. La activación de SYK por su unión al hemITAM permite la formación del complejo CARD9/Bcl10/Malt-1 que induce la activación de la subunidad p65 de NF-kB y de c-Rel y también la activación de la subunidad RelB por la quinasa NIK. La vía de señalización de RAF1 regula la actividad de p65 inducida por TLR. Adicionalmente, la activación del complejo que incluye CARD9 puede regularse por dectin-2, y RAF1 por DC-SIGN.

DC-SIGN (dendritic cell-specific ICAM-3 grabbing non integrin) contiene siete secuencias repetidas en tándem que permiten la multimerización del receptor y una cola citoplasmática con varios motivos de internalización (Figura 5). Inicialmente se describió como un receptor capaz de unirse a la molécula de adhesión intercelular-3 (ICAM-3 intercellular adhesion molecule) para mediar interacciones entre las CD y los linfocitos $T$, facilitando de esa forma la presentación antigénica y la coestimulación (Geijtenbeek et al., 2000). Se expresa principalmente en CD inmaduras y media el reconocimiento de carbohidratos con alto contenido en residuos de manosa de manera dependiente de $\mathrm{Ca}^{2+}$ (Willment y Brown, 2007; Ishii et al., 2008 y Romani, 2011). Está implicado en la fagocitosis de Candida albicans en cooperación con galectina 3 (otro miembro de la familia de los CLR) y TLR2 (Netea et al., 2008). La activación de NF-kB se produce por la cooperación con TLRs (Gringhuis et al., 2007). El TLR induce la señal para la activación de NF-אB y la señal de DC-SIGN activa la vía de señalización de la quinasa RAF1, que fosforila NF-kB en la serina 276 de la subunidad p65 para su posterior acetilación e 
incremento de su afinidad de unión al ADN y de la actividad transcripcional (Geijtenbeek y Gringhuis, 2009).

Dectin-2, denominada también CLEC6a, tiene una cola citoplasmática corta sin motivos de señalización (Figura 5) por lo que precisa interaccionar con FcR y y DAP12 para inducir el reclutamiento de SYK y la subsecuente activación de NF-אB, sin embargo, la activación de la vía SYK/CARD9/NF-kB por este receptor no ha podido ser confirmada (Romani, 2011; Netea et al., 2008). La unión del ligando es dependiente de $\mathrm{Ca}^{2+}$ y se une a $\alpha$-mananos presentes en la membrana celular de hongos. En los hongos dimórficos, muestra mayor capacidad para reconocer las formas de hifas que las levaduras (Willment y Gordon, 2007; Romani 2011).

El RM recibe su nombre por su capacidad para reconocer de manera dependiente de $\mathrm{Ca}^{2+}$ moléculas con residuos de manosa, fucosa y $\mathrm{N}$-acetilglucosamina en la porción terminal. Forma parte de una familia de receptores con multilectinas que incluye los receptores Endo-180, DEC-205 y el receptor de fosfolipasas secretadas. Posee ocho CTLD y carece de motivos de señalización en la cola citoplasmática. La ausencia de estos motivos hace necesaria la cooperación con TLRs y dectin-1 para inducir la producción de citoquinas inflamatorias (Romani, 2011; Alvarez et al., 2010).

Dectin-1, denominada también CLEC7a, es el principal PRR de reconocimiento de $\beta$ (1,3)-glucanos mediante un CTLD acoplado a la región transmembrana. La cola citoplasmática contiene una secuencia hemITAM conectada por una pequeña región denominada cuello al dominio transmembrana (Figuras 5 y 6 ). Se ha propuesto que su ocupación por el ligando produce una dimerización de dos moléculas de dectin-1 para proporcionar un sitio trans de acoplamiento para los dos dominios SH2 de SYK (Osorio y Sousa, 2011) y permitir el reclutamiento de SYK, la activación de CARD9 y NIK (NF-кB inducing kinase) y la producción de ROS (Ishii et al., 2008; Romani, 2011). De esa forma, dectin-1 activa la vía canónica y no canónica de NF-אB, y el inflamasoma NLRP3 (Geijtenbeek y Gringhuis, 2009).

El gen que codifica el receptor en ratón sufre un empalme alternativo en el exón tres (exón del cuello), lo que produce dos isoformas que se diferencian por la presencia o ausencia de cuello (Heinsbroek et al., 2006). En el humano existen dos isoformas mayoritarias (A y B) y seis minoritarias $(\mathrm{C}-\mathrm{H})$. Las isoformas mayoritarias son la únicas capaces de reconocer el ligando y difieren por la presencia (isoforma A) o ausencia (isoforma B) de cuello (Willment et al., 2001) (Figura 6). La expresión de este receptor se regula positivamente por factores de crecimiento como el GM-CSF, la IL-4 y la IL-13, y negativamente por LPS e IL-10 (Willment et al., 2003). 


\section{Isoforma A}

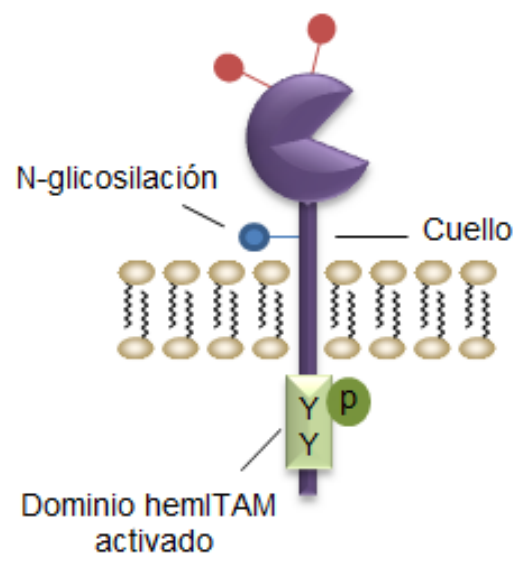

Isoforma B

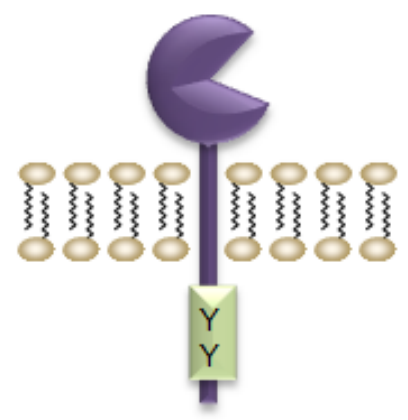

Figura 6: Estructura de dectin-1. Dectin 1 es un receptor transmembrana de tipo II con un solo CRD separado de la membrana por la región del cuello (isoforma A). Puede sufrir empalme alternativo, lo que origina la isoforma $B$ que no presenta la región del cuello. El dominio citoplasmático contiene un motivo tipo ITAM que al ser fosforilado produce la señal intracelular. Dectin-1 también contiene un sitio de N-glicosilasión en el CRD (rojo, ratón) o en la región del cuello (azul, humanos). P: fosfato. Adaptada de Brown, 2006.

En los últimos años se ha caracterizado otro CLR denominado CLE9a que contiene en su porción citoplasmática un dominio hemITAM con una sola secuencia de tirosina que permite la señalización a través de SYK (Huysamen et al., 2008; Sancho et al., 2009; Zhang et al., 2012). Este receptor se expresa en CD y está implicado en el reconocimiento de células que sufren apoptosis, principalmente, en las fases tardías y de necrosis (Sancho et al., 2009; Zhang et al., 2012). El ligando es un componente del citoesqueleto de actina (Zhang et al., 2012).

\section{Patrones moleculares asociados a patógenos}

Los PAMP son estructuras conservadas en los microorganismos a lo largo del proceso evolutivo. De acuerdo con la naturaleza del microorganismo invasor, la inmunidad innata puede distinguir: i) Si los PAMP se presentan en forma soluble o particulada, ii) microorganismos vivos de muertos mediante el reconocimiento de estructuras presente en los organismos vivos, como el ARNm y iii) la patogenicidad de los microorganismos mediante la detención de factores de virulencia. Estos puntos son críticos para la discriminación del potencial patogénico de los microorganismos y contribuyen a escalar la respuesta inmunológica (Blander y Sander, 2012).

En el caso de las infecciones por hongos, el reconocimiento se hace a través de los componentes de la pared celular, entre los cuales se encuentran los $\beta$-glucanos, residuos de manosa y quitina. En el caso de las bacterias se reconocen lipopolisacárido y peptidoglicanos. 
Los $\beta$-glucanos son polisacáridos de glucosa con enlaces tipo $\beta-(1-3)$ y $\beta-(1-6)$ y representan entre el 50-60\% de la pared celular de los hongos. El reconocimiento es mediado principalmente por dectin-1 que reconoce específicamente $\beta$-(1,3) glucanos (Netea et al., 2008). Otro PRR que puede reconocer $\beta$-glucanos es el CR3 (complement receptor 3 ), un heterodímero de cadenas $C D 11 b$ y $C D 18$, que reconoce tanto $\beta$-glucanos opsonizados por el componente del complemento C3bi, como sin opsonizar (Netea et al., 2008).

Los mananos son polímeros de manosa unidos covalentemente a proteínas mediante enlaces O-glicosídicos y $\mathrm{N}$-glicosídicos para formar manoproteínas. El reconocimiento de los mananos es mediado por CLRs y TLRs. Así, se ha descrito que el RM reconoce $\alpha$-mananos unidos por enlaces $\mathrm{N}$-glicosídicos y TLR4 reconoce los enlaces O-glicosídicos (Netea et al., 2006, 2008).

La quitina está compuesta por polímeros de $\mathrm{N}$-acetilglucosamina y constituye la parte más interna de la pared celular en contacto con el núcleo de $\beta$-glucanos y la membrana plasmática (Netea et al., 2006). Es el polisacárido menos estudiado y se conoce poco acerca de sus rutas de reconocimiento.

El zymosan es una preparación insoluble de la pared celular de la levadura Saccharomyces cerevisiae que se utiliza desde hace más de 50 años como modelo fagocítico e inflamatorio in vivo e in vitro. Se compone, principalmente, de $\beta-(1-3)$ y $\beta-(1-6)$ glucanos, mananos, quitinas, proteínas y lípidos. El reconocimiento del zymosan se realiza por dectin-1, TLR2 (Dillon et al., 2006) y DC-SIGN (De la Rosa et al., 2005).

EI LPS está presente en la membrana externa de las bacterias Gram-negativas y se compone de tres porciones de las cuales dos de ellas son hidrofílicas: la porción central que posee motivos repetidos y la región denominada antígeno 0 . El dominio hidrofóbico presenta seis cadenas de ácidos grasos, se denomina lípido $\mathrm{A}$ y es el responsable de la virulencia. Es reconocido por el receptor TLR4 y promueve la secreción de citoquinas pro-inflamatorias en las APC

\section{Reconocimiento de células apoptóticas}

La fagocitosis de las CA es imprescindible para mantener la homeostasis celular. La no eliminación de estas células conduce a la aparición de necrosis secundaria y al desencadenamiento de respuestas inflamatorias y autoinmunes (Peter et al., 2010). La apoptosis ocurre mediante una secuencia de eventos caracterizados por: la exposición de diversas 
moléculas al exterior celular como la fosfatidilserina (PS), la fragmentación del ADN y la liberación de fragmentos de membranas llamados cuerpos apoptóticos (Albert et al., 1998). Las moléculas expuestas pueden ser proteínas modificadas o moléculas no expresadas habitualmente en la membrana externa, que se conocen como patrones moleculares asociados a células apoptóticas (ACAMP). Gracias a estas moléculas y a los factores quimioatrayentes, como la esfingosina-1- fosfato, las CA pueden ser reconocidas por $\mathrm{CD}$ y $\mathrm{M} \varnothing$ y eliminadas sin la inducción de una respuesta inflamatoria (Albert et al., 1998).

Se han identificado varios receptores que participan en el reconocimiento de las CA, entre los que se encuentran el receptor de fosfatidilserina (PSR), el receptor de unión a lipopolisacárido, CD14, receptores de tipo integrina (integrina $\alpha-v \beta 3$ y $\alpha \vee \beta 5$ y CR3/CR4), los receptores scavengers de clase A (SR-A), de clase B (CD36 y SR-B1) y de clase E (LOX-1, lectin-like oxidized low-density lipoprotein receptor 1), CD91 (también conocido como LPR, lowdensity lipoprotein receptor-related protein), receptores de colectinas y el receptor con actividad de tirosina quinasa Mer (Figura 7) (Erwig y Henson 2008; Taylor et al., 2005). Existen también moléculas solubles denominadas opsoninas que sirven de puente para el reconocimiento de las CA, entre las que se incluyen proteínas del suero como C3bi y C1q, Gas6 (growth arrest-specific gene product), MFG-E8 (milk fat globule protein), $\beta 2$-glicoproteina I ( $\beta 2-\mathrm{GPI}$ ) y las anexinas I/II (Figura 7).

EI PSR reconoce la fosfatidil-L-serina pero no la fosfatidil-D-serina (Taylor et al., 2005). Se describió por primera vez junto a la pérdida de la simetría de la membrana externa por Fadok y col. (1992). Estudios realizados en ratones silvestres y deficientes en PSR no revelaron diferencias en la fagocitosis de las CA (Böse et al., 2004), lo que sugirió que el PSR no contribuye directamente en el reconocimiento de la PS. En este sentido, se han identificado dos glicoproteínas que parecen actuar de manera más eficientemente, como son TIM-1 y TIM-4 ( $T$ cell Immunoglobulin domain and mucin domain). Ambas se unen con alta afinidad y especificidad a la PS mediante su dominio de inmunoglobulina y promueven la fagocitosis de las CA (Miyanishi et al., 2007). Asimismo, las moléculas de estabilina-2 (stabilin-2) y BAI-1 (brainspecific angiogénesis inhibitor 1) también han mostrado afinidad por la PS, e incluso se ha sugerido que la estabilina-2 pueda estar involucrada en la inducción de TGF- $\beta$ (Torchinsky et al., 2010). 


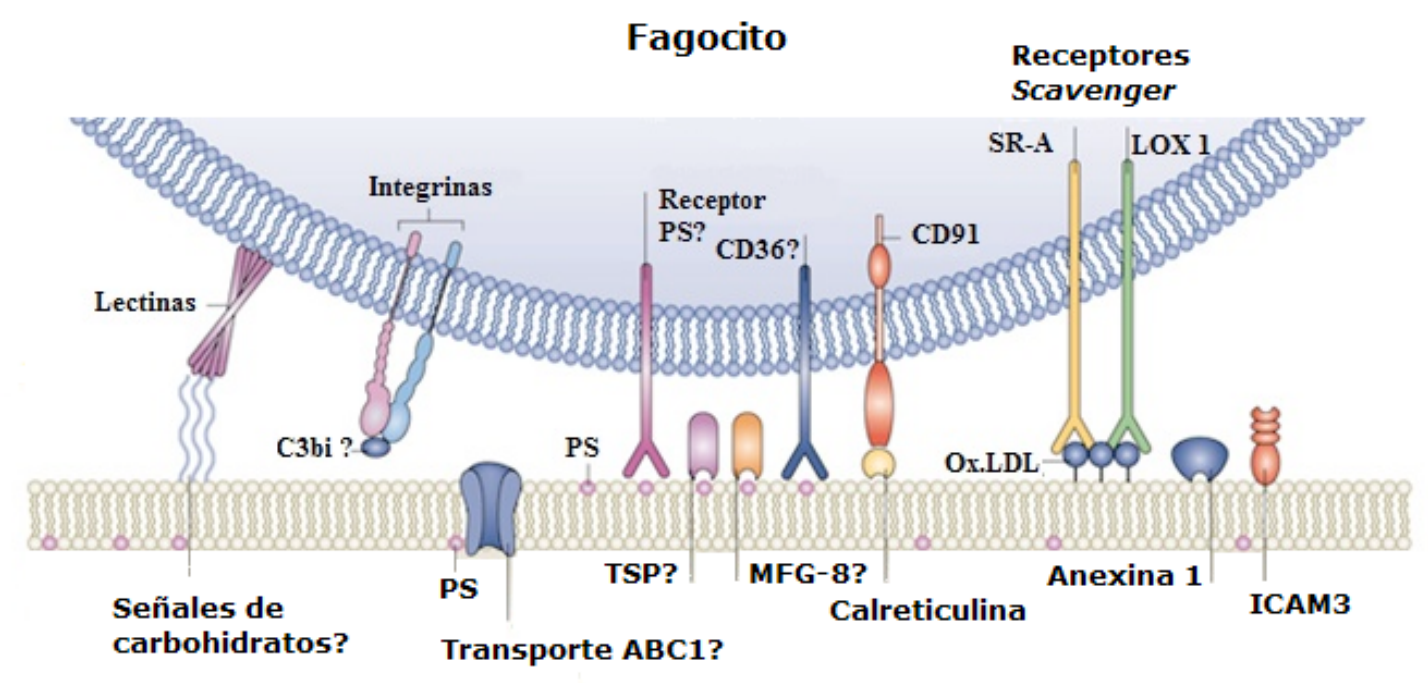

Célula apoptótica

Figura 7: Esquema de los receptores y ligandos que promueven la fagocitosis de las CA. El esquema muestra las moléculas propuestas para el reconocimiento de las $C A$ por $C D$ y $M \varnothing$. La fosfatidilserina (PS) puede ser reconocida por los receptores trombospondina (TSP) y CD36. La PS puede promover la opsonización de las CA por el factor del complemento C3bi y promover el reconocimiento por las integrinas (receptores del complemento CR3 y CR4). La calcireticulina se expone en la superficie externa de las células muertas y es reconocida por CD91, mientras que las lipoproteínas oxidadas de baja densidad (Ox-LDL) pueden ser reconocidas por receptores scavenger (SR-A y LOX1). Entre los ligandos de las CA también se incluyen la anexina-1 y el ICAM-3, y entre los receptores de los fagocitos que no tienen ligandos conocidos se incluyen las lectinas y miembro de la familia de integrinas. $\mathrm{ABC} 1$ es el acrónimo de ATP-binding cassette transporter y está implicado en el transporte de de distintos sustratos a través de la membrana. Adaptada de Taylor et al., 2008.

CD14 se encuentra anclado a la membrana plasmática y también en forma soluble en el plasma sanguíneo (Gregory et al., 2000). El reconocimiento de las CA por este receptor depende de la presencia de ICAM-3 alterado y expresado en las CA, que funcionaría como un ligando (Gregory et al., 2000; Taylor et al., 2005; Erwig y Henson 2008). CD14 también se une a fosfolípidos como la PS (Gregory et al., 2000).

Los receptores de tipo vitronectina (integrina $\alpha \vee \beta 3$ y $\alpha \vee \beta 5$ ) son integrinas heterodiméricas transmembrana compuestas por dos cadenas que tienen un papel importante en la adhesión, migración celular y angiogénesis (Albert et al., 1998). La integrina $\alpha v \beta 3$ fue el primer receptor identificado en la fagocitosis de leucocitos apoptóticos por $\mathrm{M} \varnothing$, coopera con CD36 y trombospondina (TSP), que actúa como "puente" para permitir la unión de los receptores (Taylor et al., 2005). La integrina $\alpha \vee \beta 5$ también coopera con CD36 en la fagocitosis de las CA (Albert et al., 1998). 


\section{- Receptores scavenger}

Estos receptores son glicoproteínas de la membrana plasmática implicadas en el reconocimiento de lipoproteínas modificadas (oxidadas [ox] o acetiladas [ac]) de baja densidad (LDL, low density lipoprotein). Dado que las CA sufren estrés oxidativo, sus lipoproteínas oxidadas pueden estar presentes en su superficie y ser reconocidas por los receptores scavenger.

SR-A media el reconocimiento de ox-LDL, ac-LDL y LPS por M $\varnothing$ (Jeanni et al., 2008) y su expresión se restringe a estas células. En M $\varnothing$ de ratones deficientes en SR-A se describió una disminución de la fagocitosis de timocitos apoptóticos del $50 \%$ en comparación con los $M \varnothing$ de la cepa silvestre, lo que confirmaría la participación de más de un receptor durante el reconocimiento de las CA (Franc et al., 1999). Se han propuesto dos vías por las que SR-A participa en el reconocimiento de CA. La primera incluiría la unión de CD14 a las CA y la segunda implicaría la interacción con el PSR. (Devitt et al., 2003).

SR-B tiene capacidad de unirse a la PS y presenta homología con CD36. Se conocen dos variantes originadas por empalme alternativo, SR-BI y SRBII, que difieren en su dominio Cterminal. Ambos receptores se unen de manera eficiente a lipoproteínas de alta densidad (HDL, high density lipoprotein), pero SR-BI es más eficiente para el transporte del colesterol (Akpovi et al., 2006). Los primeros estudios se realizaron en células COS donde se demostró que SR-B era capaz de unirse a la PS expresada por timocitos murinos apoptóticos (Franc et al., 1999).

CD36 se une a lipoproteínas nativas. Además de cooperar con otras moléculas tiene la capacidad de unirse a fosfolípidos aniónicos, como la PS, y mediar así la fagocitosis de las CA.

LOX-1 tiene la capacidad de unirse a células senescentes y apoptóticas. Reconoce numerosos ligandos, entre los que se incluyen lipoproteínas modificadas. El papel de LOX-1 en el reconocimiento de las CA se describió utilizando ligandos específicos y liposomas de PS que inhiben su interacción con las CA, por lo que se considera que la PS actúa como ligando. LOX-1 modula la producción de citoquinas, la activación de NF-אB y la apoptosis (Taylor et al., 2005).

\section{- Receptores de colectinas, pentraxinas y complemento}

Las colectinas son un grupo de proteínas que incluye la MBL, las proteínas SP-A y SP-D y el primer componente de la vía clásica del complemento C1q (Maderna et al., 2003). Las colectinas y pentraxinas pueden opsonizar patógenos y facilitar su fagocitosis, al igual que C1q. 
A diferencia de las colectinas y las pentraxinas, C1q se une a células en fase de apoptosis temprana (Jeanni et al., 2008; Nauta et al., 2003) y promueve la eliminación de las CA además de potenciar la producción de citoquinas inflamatorias en CD (Nauta et al., 2004). Las colectinas y C1q presentan una cola de colágeno que en presencia de $\mathrm{Ca}^{2+}$ permite la unión de la calreticulina (Jeanni et al., 2008; Erwig y Henson, 2008). Esta última interacciona con CD91 y el complejo calreticulina/CD91 puede interaccionar con las proteínas SP-A y SP-D para reconocer las CA (Taylor et al., 2008; Jeanni et al., 2005).

Las pentraxinas incluyen la proteína $\mathrm{C}$ reactiva (CRP, $\mathrm{C}$ reactive protein), el amiloide $\mathrm{P}$ del suero (SAP, serum amyloid $P$ ) y la pentraxina 3 (PXT3, pentraxin 3) que se unen a las CA en fase tardías y permiten su captura por fagocitosis. CRP y SAP interaccionan para permitir la fagocitosis de CA en ausencia de moléculas del complemento, pudiendo inhibirse esta unión por fosfolípidos. Mientras que CRP y SAP inducen la fagocitosis, la PTX3 puede actuar como una opsonina inhibitoria (Jeannin et al., 2008).

\section{- Receptores con actividad tirosina quinasa}

Mer es uno de los miembros de la familia de receptores de tirosina quinasa TAM compuesta por los receptores con actividad tirosina quinasa: Tyro, Axl y Mer (Rothlin et al., 2007). Estos receptores se expresan en $M \varnothing$ y $C D$ y están implicados en la regulación de la homeostasis y activación de las APC (Sen et al., 2007). Mer participa en el reconocimiento de CA y en la inhibición de la producción de citoquinas pro-inflamatorias (Alciato et al., 2010; Sen et al., 2007). El ligando de Mer es Gas6, una opsonina con capacidad de unión a la PS. La formación del complejo Mer/Gas6/PS facilita la fagocitosis de las CA. En ratones deficientes en Mer se ha observado deficiencia en el reconocimiento de las CA y una disminución de la internalización de las CA por los M $\varnothing$ (Taylor et al., 2005).

\section{- Papel de la esfingosina-1-fosfato}

La esfingosina es un mediador lipídico producido a partir de la ceramida, que tras su fosforilación por la familia de esfingosina quinasas SPHK1 y 2 (sphingosine kinase) se convierte en esfingosina-1-fosfato (S1P, sphingosine-1-phosphate). Su concentración puede incrementarse por drogas inductoras de la apoptosis. S1P es una molécula con actividad quimioatrayente de células fagocíticas (Gude et al., 2008; Weigert et al., 2006) y un ligando 
especifico de al menos cinco receptores acoplados a proteínas G (GPCRs, G-protein-coupled receptors), denominados $\mathrm{S1P}_{1-5}$. La S1P puede incrementar los niveles intracelulares de $\mathrm{Ca}^{2+} \mathrm{y}$ de adenosina monofosfato cíclico (AMP cíclico) por lo que la activación de sus receptores puede participar en la regulación del metabolismo del ácido araquidónico (Johann et al., 2008; Brecht et al., 2011) y en la inducción de IL-10 (Weigert et al., 2007; Idzko et al., 2002).

\section{Metabolitos del ácido araquidónico}

Entre los mediadores lipídicos generados por las células del sistema inmune se encuentran las prostaglandinas, que son productos del metabolismo oxidativo del ácido araquidónico (AA) implicados en procesos inflamatorios y autoinmunes. Los metabolitos del AA se sintetizan a partir de la hidrólisis del AA de los fosfolípidos de la membrana por la activación de las fosfolipasas $A_{2}\left(P L A_{2}\right)$. La isoforma $\mathrm{CPLA}_{2} \alpha$ de la PLA $A_{2}$ citosólica (cPLA $)$ hidroliza específicamente fosfolípidos con AA. Su activación se regula por fosforilaciones en su centro activo y por el incremento de los niveles de $\mathrm{Ca}^{2+}$ intracelulares, que promueven su translocación del citosol a la membrana (Suram et al., 2010). El AA liberado sirve como sustrato para la vía de las ciclooxigenasas y la vía de las lipooxigenasas (Figura 8).
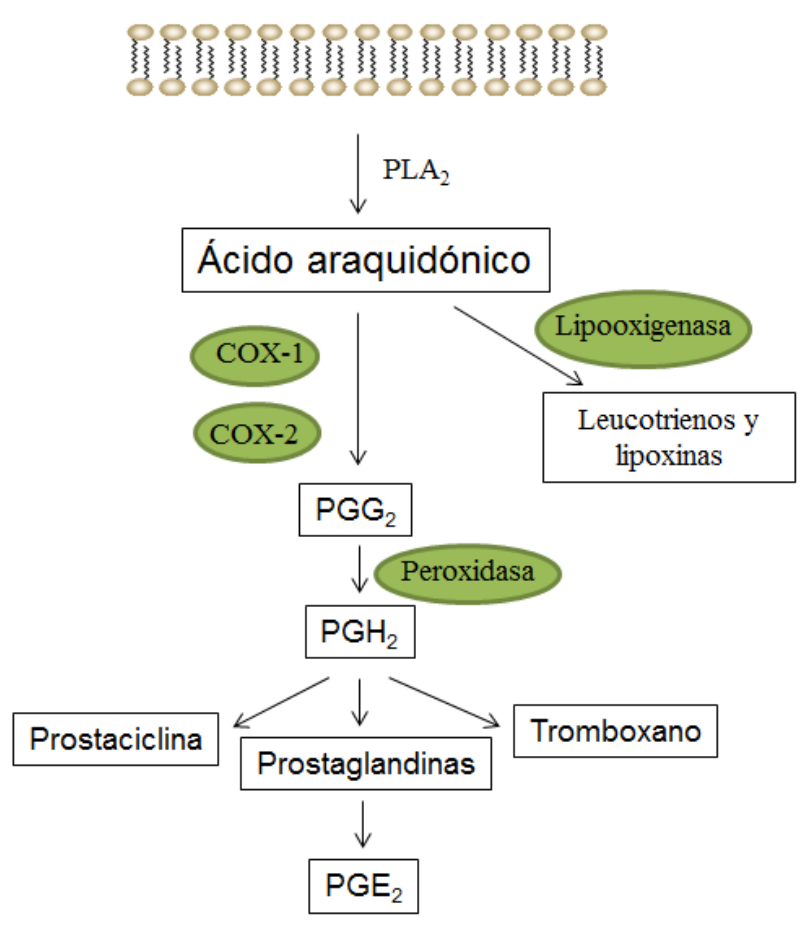

Figura 8: Esquema de la biosíntesis de eicosanoides. 
El metabolismo del AA por la vía de la ciclooxigenasa permite la formación de prostaglandinas mediante las enzimas ciclooxigenasas (COX), denominadas también prostaglandina endoperóxido sintasas. Existen dos isoformas de COX, COX-1 de expresión constitutiva que esta acoplada a la $\mathrm{CPLA} 2$ para inducir la síntesis rápida de prostaglandinas y es responsable del recambio basal de los prostanoides. En contraste, la expresión de COX-2 es inducible y se regula por factores de transcripción que se activan en la respuesta inflamatoria como NF-кB, CREB (cyclic AMP regulatory element binding protein) y C/EBP (CCAAT/enhancerbinding protein) (Kang et al., 2006).

La prostaglandina $(P G)$ más abundante es la prostaglandina $E_{2}\left(P_{G}\right)$. Su síntesis depende de las enzimas prostanglandina $E$ sintasas (PGES). Actúa de manera autocrina 0 paracrina mediante cuatro tipos de receptores GPCRs que contienen siete dominios transmembrana hidrofóbicos acoplados a proteínas $\mathrm{G}$ a través de sus secuencias intracelulares. Estos receptores se denominan receptores de prostanoides de la serie E, EP1-4, y su señal se produce por distintos segundos mensajeros (Harris et al, 2002). La señalización de EP2 y EP4 se produce mediante proteínas $G_{\alpha s}$ que incrementan los niveles intracelulares del AMP cíclico tras activar la adenilato ciclasa. La unión a receptores EP1 incrementa los niveles intracelulares de $\mathrm{Ca}^{2+}$ por su acoplamiento a proteínas $\mathrm{G}_{\alpha \mathrm{q}}$. Los receptores EP3, que están acoplados a proteínas $\mathrm{G}_{\mathrm{i}}$, disminuyen la formación de AMP cíclico (Legler et al., 2010).

La $\mathrm{PGE}_{2}$ se considera como un clásico mediador de la respuesta inmune que curiosamente puede actuar como mediador pro-inflamatorio y anti-inflamatorio. Como mediador pro-inflamatorio contribuye a la regulación del perfil de expresión de citoquinas y participa en la respuesta Th1 o Th2. Su efecto anti-inflamatorio lo ejerce modulando la actividad de las CD y $M \varnothing$. En CD puede inhibir la maduración y presentación de antígenos y en $M \varnothing$ diferenciados puede regular la producción de citoquinas, preferentemente a través de los receptores EP2 y 4, al aumentar los niveles IL-10 y disminuir los de IL-12 (Harris et al., 2002; Kalinski et al., 2001). Durante el reconocimiento de CA se ha observado que $\mathrm{PGE}_{2}$ activa el receptor EP2 y produce un aumento en la producción de IL-10 que se explicaría por un mecanismo que incluye $\mathrm{PGE}_{2} /$ receptores de prostanoides E2/adenilato ciclasa/AMP cíclico (Medeiros et al., 2009).

\section{Producción de citoquinas}

La caracterización de los mediadores químicos implicados en la eliminación de las CA por fagocitosis se ha centrado, inicialmente, en la modulación del equilibrio de las citoquinas IL- 
12 p70/IL-10 (Kim et al., 2004) y, en los últimos años, en la inducción de las citoquinas IL-23 y TGF- $\beta 1$, que contribuyen a la diferenciación de las células Th17 (Torchinski et al., 2009; Brereton y Blander, 2010). En este sentido, Zhang y col. (2010) propusieron que el reconocimiento de las CA suprime la respuesta inmune a través de la liberación de citoquinas anti-inflamatorias como IL-10 y TGF- $\beta 1$ y la inhibición de citoquinas pro-inflamatorias como IL-12 p70. Dado que el patrón de producción de citoquinas durante el reconocimiento de hongos se caracteriza por elevados niveles de IL-10 y baja secreción de IL-12 p70 (Dillon et al., 2006), estos antecedentes sugieren que la fagocitosis de las CA induce una respuesta de citoquinas similar a la observada durante las infecciones fúngicas.

\section{- Interleuquina 10 (IL-10)}

Esta citoquina es un potente mediador anti-inflamatorio que puede regular las fases tardías de la respuesta inflamatoria por sus propiedades anti-inflamatorias e inmunosupresoras. Su señal se produce a través de un complejo de dos cadenas transmembrana, IL-10R1 e IL10R2, que activan las tirosina quinasas Janus 1(JAK)1 y tirosina quinasa 2 (Tyk) 2 asociadas a cada cadena. Estas quinasas fosforilan STAT3, un factor de transcripción de la familia STAT (signal transducers and activator of transcription), que incluso regula positivamente la transcripción del propio gen de IL-10. En CD y M $\varnothing$ puede inhibir la presentación de antígenos al reducir la expresión del MHC de clase $\|$ y de las moléculas coestimuladoras CD80 y CD86. También puede inhibir la expresión de citoquinas pro-inflamatorias (Mosser y Zhang, 2008).

Se han descrito numerosos factores de transcripción que regulan la producción de esta citoquina. Entre los que se destacan NF-kB, CREB y PBX1b (pre-B cell leukemia transcription factor-1b) (Mosser y Zhang, 2008; Chung et al., 2007). La capacidad de IL-10 para inhibir la producción de genes pro-inflamatorios se atribuye a su capacidad para contrarrestar la actividad de la subunidad p65 de NF-кB. La producción de IL-10 es más intensa con algunos estímulos como los $\beta$-glucanos, que actuarían a través de CREB (Alvarez et al., 2009), y las CA, que actuarían a través de PBX1 (Chung et al., 2007).

\section{- Interleuquina 12 (IL-12 p70)}

IL-12 p70 es la principal citoquina inmunoreguladora de la respuesta tipo Th1 y un potente mediador pro-inflamatorio con un papel importante en la conexión entre la inmunidad 
innata y adaptativa. Se compone de dos subunidades que forman un heterodímero: una de 35 kDa (p35, il12a) y otra de $40 \mathrm{kDa}$ (p40, il12/23b), que se codifican por genes distintos. La regulación de il12/23b es dependiente de la activación de NF- $\kappa B$, mientras que la regulación de il12a requiere, además, la presencia de un ciclo paracrino que incluye los factores reguladores de interferón (IRF)-1, IRF-3 e IRF-8/ICSBP (interferón consensus sequence binding protein) (Gautier et al., 2005). La sub-unidad p35 solo se secreta cuando está unida covalentemente a p40 (Tato y Cua, 2008), no obstante, esta última se secreta en exceso sobre el heterodímero IL12 p70 y a su vez puede formar homodímeros, denominados IL-12 p80 o IL-12 p(40)2, que se unen al receptor de IL-12 (IL-12R) y actúan como antagonistas sin desencadenar una respuesta biológica (Hölscher, 2004). El receptor de IL-12 p70 está formado por 2 cadenas IL-12Rß1 e IL$12 R \beta 2$, la primera une a la sub-unidad p40 y está asociada con Tyk2 y la segunda reconoce el heterodímero y la cadena p35, y se asocia con Jak2 (Lyakh et al., 2008). La señalización a través del complejo receptor induce fosforilación, dimerización y translocación nuclear de varios elementos de la familia STAT (1/3/4/5), pero la respuesta biológica depende de STAT4 (Lyakh et al., 2008). Dado que el efecto pro-inflamatorio puede generar daño tisular, la producción de IL-12 p70 se regula por un mecanismo de retroalimentación positiva mediante la liberación de IFN- $\gamma$ por parte de las células T y NK, y negativamente por la IL-10 (Trinchieri, 1997).

\section{- Interleuquina 23 (IL-23)}

IL-23 es una citoquina pro-inflamatoria que favorece la proliferación y diferenciación de células Th17. Forma parte de la familia de citoquinas de IL-12 p70 con la que comparte la subunidad p40 (il12/23b) formando un heterodímero con una sub-unidad de $19 \mathrm{kDa}$ (p19, il23a). Al igual que la sub-unidad p35 de IL-12 p70, p19 no se secreta en ausencia de la cadena p40. El complejo receptor de IL-23 es un heterodímero compuesto por las cadenas IL-12Rß1 e IL-23R (Tato y Cua, 2008). La señalización por esta citoquina es similar a la de IL-12 p70, puesto que activa Tyk2, Jak2 y STAT1/3/4, sin embargo, la activación de STAT4 no es tan importante como en el caso de IL-12 p70 y predomina la formación de dímeros de STAT3/4 (Lyakh et al., 2008).

\section{- Regulación de la producción de IL-12 p70 e IL-23}

El balance entre IL-12 e IL-23 depende del tipo de estímulo, con la particularidad de que los ligandos que se unen a un solo receptor no son eficientes para la producción de estas 
citoquinas y a menudo sólo inducen niveles bajos de IL-12 p40. La activación de varios PRR puede aumentar la producción significativamente (Lyakh et al., 2008). Por ejemplo, la activación de dectin-1 por el zymosan induce una importante producción de IL-23, IL-10 e IL-6, pero la coestimulación de dectin-1 con TLR2 potencia la liberación de estas citoquinas y disminuye la liberación de IL-12 p70, en comparación con los niveles obtenidos con la estimulación de TLR2 (Dennehy et al., 2009). La potenciación de la producción de IL-23 se debe a un incremento de los transcriptos codificantes de la sub-unidad de IL-23 p19, mientras que la disminución de la producción de IL-12 p70 se explica por la reducción de los transcriptos de IL-12 p35. De esta forma, la producción de estas citoquinas se regula mediante la transcripción de las cadenas propias de cada una de ellas.

La producción de IL-12 p70 puede inhibirse por la PGE2 y el AMP cíclico, que disminuyen la expresión de il12/23b (Kalinski et al., 2001). Por el contrario, PGE 2 puede aumentar la producción de IL-23 (Sheibanie et al., 2004).

La región proximal al promotor de il12a contiene diferentes sitios de unión de factores de transcripción. Entre ellos un sitio $\kappa \mathrm{B}$, un elemento de respuesta a IFN- $\gamma(\gamma-\mathrm{IRE})$ y un sitio C/EBP. El análisis de la región promotora de il12/23b se ha estudiado en respuesta a LPS y se ha observado la necesidad de la remodelación del nucleosoma 1 para que puedan unirse los factores de transcripción. El promotor de IL-23 p19 contiene dos sitios de unión de NF-אB donde se une preferentemente c-Rel (Lyakh et al., 2008).

\section{Regulación transcripcional}

La respuesta a los PAMP induce la expresión de proteínas de manera dependiente del estímulo y del patrón de activación de los factores de transcripción. En el caso de la respuesta a las CA, es necesario tener en cuenta, además de los factores de transcripción, el papel de coactivadores y corepresores que intervienen en la regulación transcripcional de las citoquinas. En general, NF- $\kappa B$ es el factor más importante en la producción de IL-12 p70 y CREB es el factor más importante en la regulación transcripcional de IL-10 (Ananieva et al., 2008, Alvarez et al., 2009, Mellet et al., 2011). Puesto que los datos disponibles en la literatura indican que el reconocimiento de las CA induce la producción de IL-10 y reduce la de IL-12 p70, de manera similar a lo que ocurre en respuesta al reconocimiento de los patrones derivados de hongos, parece verosímil pensar que puede existir una gran analogía de los mecanismos de señalización activados en ambos casos. 


\section{- CREB y sus coactivadores}

CREB presenta una organización modular. En el extremo N-terminal tiene un dominio de transactivación (TAD) bimodular compuesto por un dominio central inducible por la quinasa (KID), que permite su activación en respuesta al AMP cíclico y a $\mathrm{Ca}^{2+}$ por mecanismos dependientes de fosforilaciones, y un dominio de transactivación constitutivo rico en glutamato (Q2), que potencia la transcripción por la interacción con el factor asociado a TBP 4 (TAF4). El extremo C-terminal presenta un dominio básico zipper de leucinas (bZIP) que promueve la unión y dimerización de CREB al ADN (Altarejos y Montminy, 2011) (Figura 9).

La actividad de CREB depende de la convergencia de las señales de AMP cíclico y $\mathrm{Ca}^{2+}$ que estimulan la fosforilación de CREB. Las señales dependientes de AMP cíclico fosforilan CREB a través de la proteína quinasa $\mathrm{A}$ (PKA, CAMP-protein kinase $A$ ) y las señales de $\mathrm{Ca}^{2+}$ actúan mediante las quinasas dependientes de $\mathrm{Ca}^{2+}$ y calmodulina.

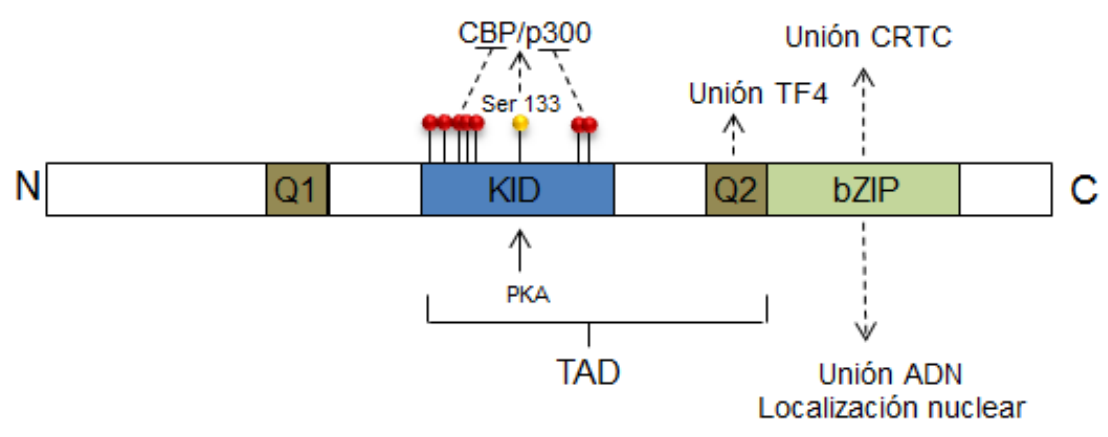

Figura 9: Organización modular de CREB. Está formado por los dos dominios ricos en glutamato (Q1 y Q2), el dominio central KID y el dominio básico bZIP en la porción C-terminal. Los dominios KID y Q2 componen al dominio de transactivación (TAD). La fosforilación de la serina 133 permite la interacción de CBP/p300 con CREB. El dominio bZIP promueve la unión de CRTC y permite la interacción entre CREB y CRTC. Adaptada de Altarejos y Montminy, 2011.

La fosforilación de CREB en la serina 133 del dominio KID promueve su asociación con el dominio KIX de CBP (CREB-binding protein)/p300, lo que estimula la expresión de los genes dianas de CREB (Radhakrishnan et al., 1997) por la acetilación de las histonas nucleosomales y el reclutamiento del complejo de la ARN polimerasa II (Kee et al., 1996). Adicionalmente, el dominio bZIP también permite la unión de la familia de los coactivadores CRTC o TORC (cyclic AMP-regulated transcriptional coactivator) que contribuyen a la actividad de CREB a través de señales dependientes de AMP cíclico y $\mathrm{Ca}^{2+}$ (Katoh et al., 2006) (Figura 9).

El mecanismo mejor establecido de la activación de CREB se inicia por la unión de ligandos a los GPCRs acoplados a proteínas $\mathrm{G}_{\mathrm{s}}$, como los receptores EP2 y EP4. Esta unión desencadena la activación de las adenilato ciclasas y la formación de AMP cíclico a partir de 
ATP. La unión del AMP cíclico a las subunidades reguladora de la PKA libera las subunidades catalíticas y permite su migración al núcleo por un proceso pasivo (Altarejos y Montminy, 2011). La PKA fosforila CREB en la serina 133 con un patrón temporal que alcanza niveles máximos entre 30 minutos y 1 hora en correlación directa con la cantidad de la subunidad catalítica de PKA liberada por el AMP cíclico (Hagiwara et al, 1993) (Figura 10, panel izquierdo). CREB fosforilado estimula el reclutamiento del coactivador CBP/P300 y paralelamente se induce la translocación nuclear del coactivador CRTC. Los CRTC se encuentran retenidos en el citoplasma unidos a la proteína 14-3-3. Esta interacción se regula por un mecanismo de fosforilación/defosforilación bajo el control de la actividad de las quinasas inducibles por sal (SIK, salt-inducible kinase) que, a su vez se regulan negativamente por la actividad de PKA (Katoh et al., 2006) y de la calcineurina. Los aumentos de los niveles de AMP cíclico inhibe las SIK y el aumento de los niveles de $\mathrm{Ca}^{2+}$ inducen la desfosforilación por la calcineurina. El resultado es la translocación al núcleo de los CRTC y su unión al dominio bZIP de CREB (Screaton et al., 2004; Katoh et al., 2006). De esta forma, los niveles intracelulares de AMP cíclico y $\mathrm{Ca}^{2+}$ regulan dos pasos esenciales de la activación de CREB (Figura 10, panel derecho).
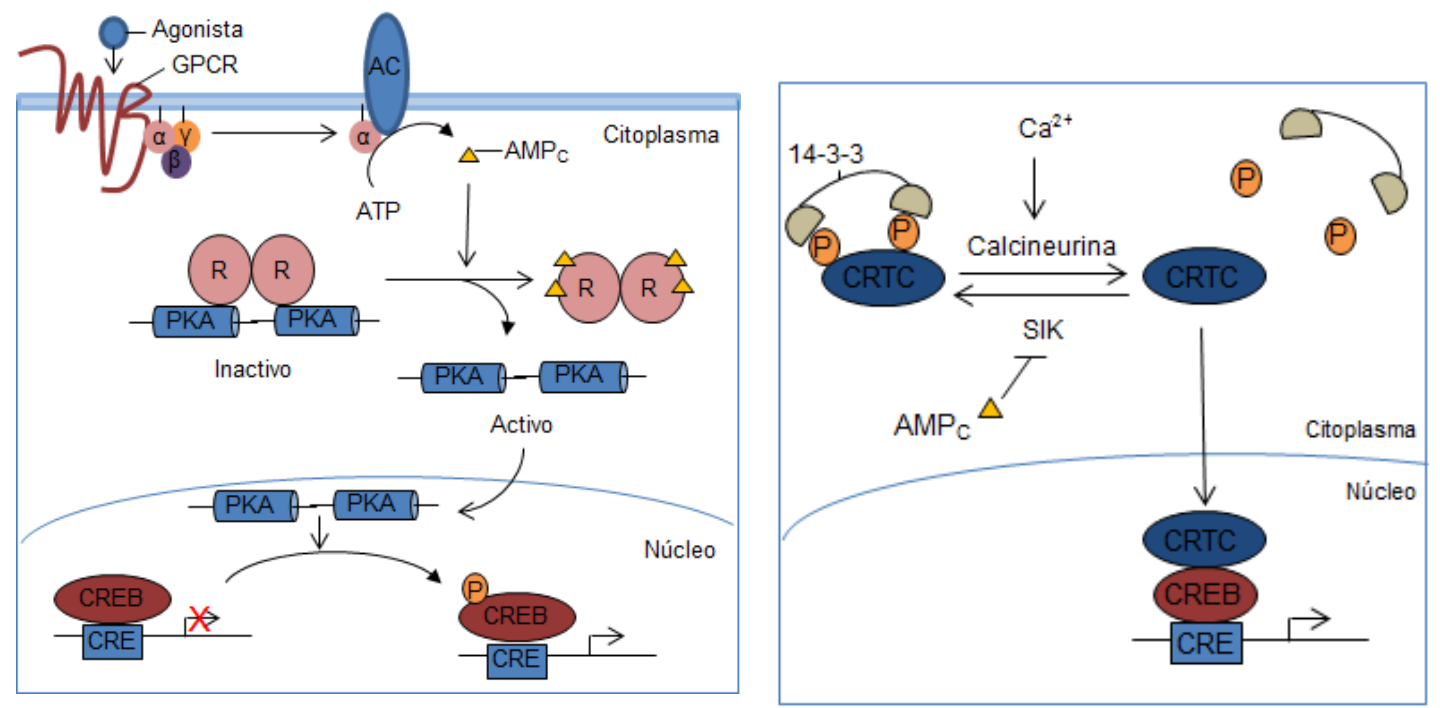

Figura 10: Fosforilación de CREB por AMP cíclico y translocación de CRTC. La unión del ligando a los GPCR activa las adenilato ciclasas (AC) que catalizan la síntesis del AMP cíclico. El incremento del AMP cíclico en el citoplasma activa la PKA mediante la unión a las sub-unidades reguladoras PKA (R) y la liberación de las subunidades catalíticas. Esto permite la translocación al núcleo y la fosforilación de CREB. CREB fosforilado promueve la expresión de los genes con sitios CRE en el promotor (panel izquierdo). Las señales del AMP cíclico y $\mathrm{Ca}^{2+}$ promueven la desfosforilación del CRTC por inhibición de SIK y activación de la calcineurina. CRTC desfosforilado se transloca al núcleo donde se une a CREB y estimula su actividad (Panel derecho). Adaptada de Altarejos y Montminy, 2011. 


\section{- La homeoproteína PBX1}

PBX1 es un cofactor de la familia de factores de transcripción HOX que actúa de manera cooperativa con otras homeoproteínas y forma heterodímeros con MEIS, PREP y HOX (Mosser y Zhang, 2008). La actividad transcripcional de PBX1 se ha asociado también con la formación de un complejo que a través de MEIS implica la participación de la familia de coactivadores CRTC (Goh et al., 2009). El mecanismo por el que PBX1 regula la transcripción de IL-10 se ha estudiado durante la fagocitosis de CA y se ha referido que su actividad funcional depende de la interacción con la proteína PREP1 (Pbx-regulating protein 1) y la unión al sitio denominado elemento de respuesta a CA (ACRE, apoptotic cell response element) (Chung et al., 2007).

\section{- Actividad de PPAR- $\gamma$}

El PPAR- $\gamma$ (peroxisome proliferator-activated receptor- $\gamma$ ) tiene un papel en la regulación transcripcional de la diferenciación celular, inflamación y metabolismo lipídico de CD y M $\varnothing$. En $M \varnothing$ se ha observado que la alta expresión del PPAR- $\gamma$ se relaciona con la acumulación de lípidos en el citoplasma en estructuras denominadas cuerpos lipídicos que se forman durante las infecciones, por lo que se considera que este factor de transcripción puede regular la formación de estas estructuras, que a su vez tienen un papel importante en la producción de $\mathrm{PGE}_{2}$ (Almeida et al., 2009). Durante la fagocitosis de CA se ha propuesto que PPAR- $\gamma$ actúa como un sensor de ácidos grasos modificados y esteroles (Torchinsky et al., 2010).

El PPAR- $\gamma$ es uno de los miembros de la familia de receptores nucleares que heterodimerizan con el receptor retinoide $X(R X R)$. Tiene un papel importante en la inhibición de $\mathrm{NF}-\kappa \mathrm{B}$ por un mecanismo de transrepresión, por lo que puede contribuir a la disminución de la liberación de citoquinas pro-inflamatorias (Vargas y Nagy, 2008). La actividad del PPAR- $\gamma$ depende de su unión al elemento de respuesta de proliferación del peroxisoma (PPREs). Tras formar heterodímeros con RXR, recluta un complejo de proteínas que incluye coactivadores 0 corepresores. En ausencia de ligandos, el heterodímero PPAR- $\gamma / R X R$ unido al PPREs favorece la unión de moléculas corepresoras que inhiben la actividad transcripcional de NF-кB. Por el contrario, en presencia de ligandos, el heterodímero experimenta un cambio conformacional que promueve la ubiquitinación y degradación del complejo corepresor, el reclutamiento de coactivadores y la regulación positiva de la expresión de genes (Vargas y Nagy, 2008; Bailey y Ghosh, 2005). Mediante el proceso de transrepresión, el PPAR- $\gamma$ puede secuestrar las moléculas 
coactivadoras e inhibir la actividad de NF-кB. Además, la interacción con sus ligandos permite unirse al complejo represor, manteniendo activamente el estado de represión y el bloqueo de la expresión de citoquinas (Bailey y Ghosh, 2005) (Figura 11). Las moléculas corepresoras forman un complejo de proteínas que participa en la remodelación de la cromatina, como la histona deacetilasa 3 (HDAC3), y en la ubiquitinación, como las proteínas TBL1-TBLR1 (transducin- $\beta$ like proteins).

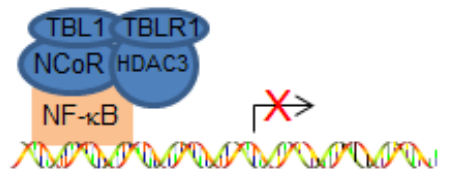

Represión

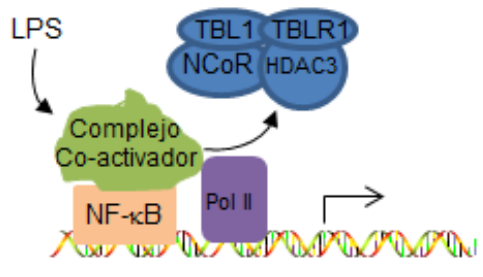

Activación

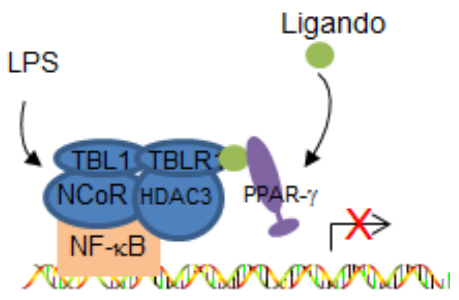

Transrepresión

Figura 11: Transrepresión del PPAR- $\gamma$. En ausencia de ligandos, el complejo NCoR (nuclear corepresor)/HDAC3/TBL1-TBLR1 reprime la transcripción de los genes regulados por NF-kB. La inducción de NF$\kappa B$ activa la degradación del complejo corepresor por ubiquitinación, favoreciendo la unión del complejo coactivador y permitiendo la activación de la transcripción. Los ligandos del PPAR- $\gamma$ pueden inducir un cambio conformacional por sumoilación induciendo la transrepresión de NF- $\mathrm{KB}$ en el promotor y por ende manteniendo el estado activo de represión. Pol II: polimerasa II. Adaptada de Bailey y Ghosh, 2005. 

| Objetivos 


\section{Objetivo General:}

Caracterizar los mecanismos moleculares asociados a la fagocitosis de células apoptóticas implicados en la producción de citoquinas y en la polarización de la respuesta inmune en respuesta a patrones moleculares de la pared de hongos.

\section{Objetivos específicos:}

1. Analizar el patrón de producción de las citoquinas IL-10, IL-12 p70 e IL-23 en células dendríticas estimuladas con zymosan y células apoptóticas.

- Analizar la producción de mediadores anti-inflamatorios liberados en respuesta a las células apoptóticas.

- Estudiar el efecto modulador de las células apoptóticas sobre la producción de citoquinas inducida por patrones moleculares derivados de la pared celular de bacterias y hongos.

2. Estudiar el efecto de las opsoninas del suero en el reconocimiento de las células apoptóticas.

3. Identificar los diferentes factores de transcripción implicados en la regulación de IL-10 y, en particular, el complejo formado por el co-activador CTRC2/TORC2 y la proteína PBX-1.

4. Determinar el efecto de las células apoptóticas sobre la inducción de la expresión de COX-2 y la producción de $\mathrm{PGE}_{2}$ en células dendríticas.

5. Analizar el efecto de la esfingosina-1-fosfato liberada por células apoptóticas en la producción de IL-10. 

Materiales y Métodos 


\section{Aislamiento y cultivo de las células}

\subsection{Aislamiento de leucocitos mononucleares y polimorfonucleares de sangre periférica}

\section{- Separación de las células mononucleares}

Las células mononucleares se obtuvieron de concentrados leucocitarios (buffy coats, término inglés que se refiere a la capa leuco-plaquetaria que se forma entre el plasma y los glóbulos rojos tras la centrifugación de la sangre total) de donantes sanos suministrados por el Biobanco del Centro de Hemodonación y Hemoterapia de Castilla y León.

La preparación suministrada se diluyó con PBS en la proporción 1:1 y se añadió sobre una solución de Ficoll-Paque (Fisher) (densidad $1.072 \mathrm{~g} / \mathrm{ml}$ ). Posteriormente, se centrifugó a 725 x g a $19^{\circ} \mathrm{C}$ durante 30 minutos, sin freno de desaceleración para conseguir la separación de las fases. Tras la centrifugación se obtuvieron cuatro fases: en la parte superior se situó la fase acuosa, conformada por el plasma y PBS, debajo de ella un anillo de células mononucleares que separa la fase anterior del Ficoll-Paque y en el fondo del tubo se situaron los eritrocitos y las células polimorfonucleares, mayoritariamente polimorfonucleares neutrófilos (Figura 12).

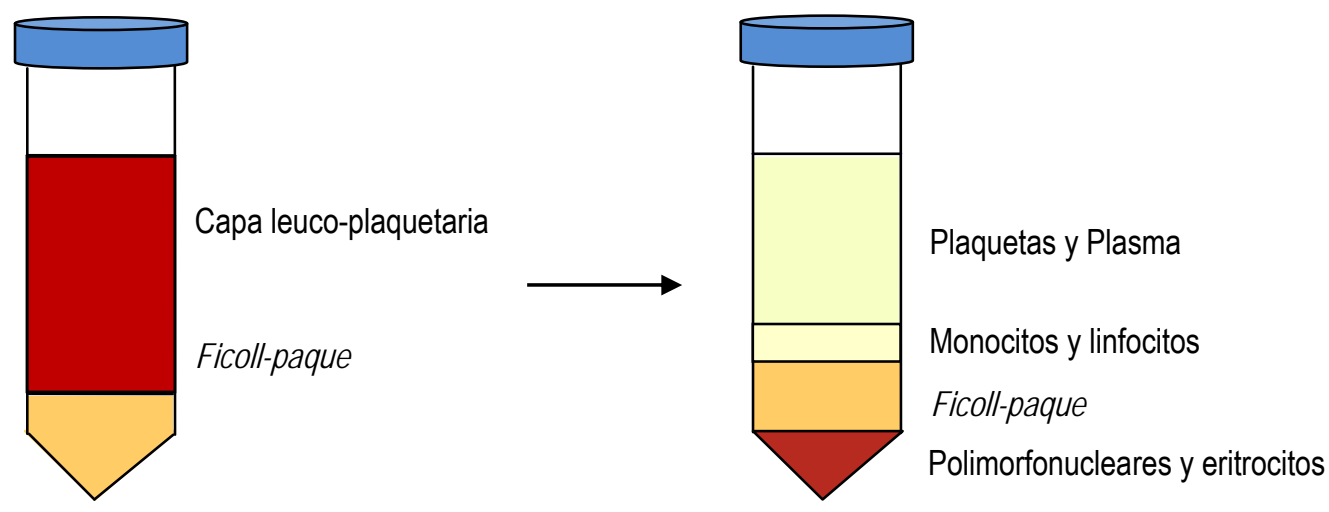

Figura 12. Representación de las fases formadas después del proceso de centrifugación. 


\section{- Diferenciación de células dendríticas}

Las células mononucleares se recogieron y se lavaron con PBS, posteriormente se centrifugaron a $450 \times \mathrm{g}$ durante 10 minutos para eliminar la mayor parte de las plaquetas presentes en la preparación. El precipitado celular se resuspendió con $3 \mathrm{ml}$ de OptiPrep (Sigma) (densidad $1.068 \mathrm{~g} / \mathrm{ml}$ ) y se añadieron lentamente $7 \mathrm{ml}$ de Ficoll-Paque, además de una mezcla compuesta por una solución salina tamponada con HEPES que contenía OptiPrep, albumina de suero bovino (BSA) y EDTA $1 \mathrm{mM}$, con la finalidad de crear un gradiente de densidad discontinuo para separar los linfocitos de los monocitos. La preparación se centrifugó sin freno a 725 x g durante 25 minutos. Después de la centrifugación se formaron varias fases: en la parte superior del tubo se formó un anillo de monocitos, seguido de la solución de OptiPrep, después se formó otro anillo conformado por los linfocitos y en el fondo del tubo el Ficoll-Paque (Figura 13). El anillo de monocitos se recogió con una pipeta Pasteur y se realizó un lavado, posteriormente se sometió a otro gradiente de densidad para así obtener una población de monocitos de mayor pureza. Por último, se procedió al recuento microscópico de los monocitos en una cámara Malassez.

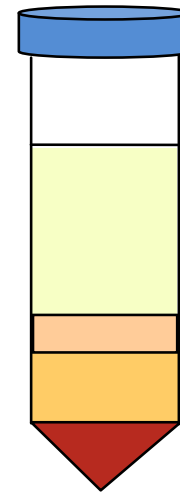

Plaquetas y Plasma

Monocitos y linfocitos

Ficoll-paque

Polimorfonucleares y

eritrocitos

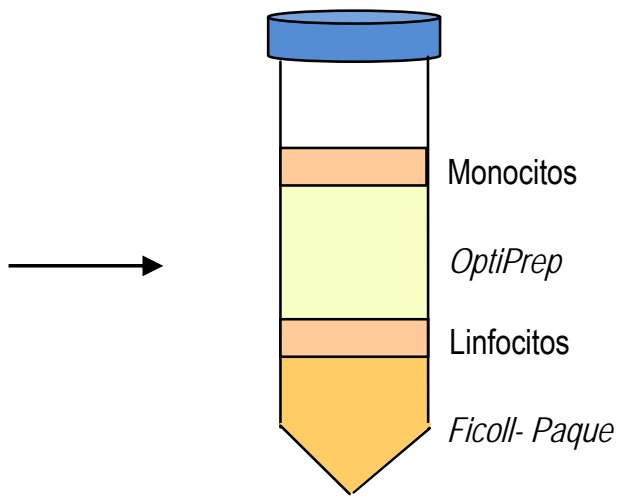

Figura 13. Representación grafica de las fases formadas por el gradiente discotinuo antes y después del proceso de centrifugación.

Los monocitos se resuspendieron en medio RPMI 1640 suplementado con $10 \%$ de FBS (fetal bovine serum) previamente inactivado por calor $\left(30\right.$ minutos a $\left.56^{\circ} \mathrm{C}\right), 2 \mathrm{mM}$ de L-glutamina y $100 \mathrm{U} / \mathrm{ml}$ de penicilina/estreptomicina. Las células se distribuyeron en placas de cultivo e incubaron durante 90 minutos para permitir la adherencia de los monocitos a la placa y la separación de los linfocitos restantes. Transcurrido ese tiempo se eliminaron los linfocitos que permanecían en suspensión. 
Para la diferenciación de los monocitos a $\mathrm{CD}$, los monocitos se incubaron durante cinco días en medio de cultivo suplementado con $800 \mathrm{U} / \mathrm{ml}$ del factor de estimulación de colonias de granulocitos-macrófagos (GM-CSF) (R\&D Systems) y $500 \mathrm{U} / \mathrm{ml}$ de IL-4 (R\&D Systems). Las incubaciones se realizaron a $37^{\circ} \mathrm{C}$ en atmósfera saturada de humedad y con un $5 \%$ de $\mathrm{CO}_{2}$.

\section{-Diferenciación de macrófagos}

Para la obtención de $M \varnothing$, las células mononucleares se lavaron dos veces más con PBS. Tras el recuento se resuspendieron a la concentración deseada en medio RPMI 1640 suplementado con $2 \mathrm{mM}$ de L-glutamina y $40 \mu \mathrm{g} / \mathrm{ml}$ de gentamicina. A continuación, se distribuyeron en placas para cultivo primario e incubaron durante una hora. Transcurrido ese tiempo, se lavaron las placas con PBS para eliminar los linfocitos en suspensión.

La diferenciación de los monocitos a $M \varnothing$ se llevó a cabo mediante el cultivo de las células en medio RPMI 1640 suplementado con $5 \%$ de suero humano (SH) inactivado por calor (SHi) o con 10\% FBS también inactivado por calor y suplementado con $10 \mathrm{ng} / \mathrm{ml}$ de factor estimulante de colonias de macrófagos (M-CSF) (Miltenyi Biotech). Las células se mantuvieron durante 7 días en incubación realizando cambios de medio cada 2-3 días y el día previo a la realización del experimento. Las incubaciones se realizaron en las mismas condiciones que las CD.

\section{-Obtención de leucocitos polimorfonucleares.}

Los PMN se purificaron de la fase inferior obtenida tras centrifugación con el FicollPaque siguiendo el protocolo descrito por Eggleton y col. (1989). A dicha fase se añadió una mezcla de Dextran al 6\% en solución salina y medio de Hank. La mezcla se dejó sedimentar por gravedad a temperatura ambiente durante 30 minutos. Posteriormente, se retiró la parte superior en la que se acumulan los PMN y se centrifugo a $800 \times$ g, a $4{ }^{\circ} \mathrm{C}$, durante 10 minutos. El sedimento obtenido contenía PMN y eritrocitos, los cuales se eliminaron mediante choques osmóticos sometiendo las células a lisis en un medio hipotónico $(\mathrm{NaCl}$ al $0.2 \%)$ durante 30 segundos y restaurando seguidamente la isotonicidad por adición de medio hipertónico $(\mathrm{NaCl}$ al 1.6\%). Tras la repetición de los choques osmóticos necesarios, los PMN se resuspendieron en PBS y se procedió a su recuento con la ayuda de un microscopio óptico y una cámara Malassez. Consecutivamente se resuspendieron en medio RPMI 1640 suplementado con 10\% de FBS, 2 
mM de L-glutamina, $100 \mathrm{U} / \mathrm{ml}$ de penicilina/estreptomicina y $10 \mathrm{mM}$ de Hepes y se incubaron a $37^{\circ} \mathrm{C}$ durante 24 y 48 horas.

\subsection{Células Jurkat}

La línea celular Jurkat (derivada de una leucemia linfoide T humana) se obtuvo de la ATCC (American Type Culture Colletion). Estas células se cultivaron en suspensión en medio RPMI 1640 suplementado con 10\% (v/v) de FBS, 2 mM de L-glutamina y $100 \mathrm{U} / \mathrm{ml}$ de penicilina/estreptomicina. Las células se mantuvieron en cultivo a la concentración de $0.1 \mathrm{x}$ $106 / \mathrm{ml}$, a $37^{\circ} \mathrm{C}$ en atmosfera saturada de humedad y con $5 \%$ de $\mathrm{CO}_{2}$. La densidad del crecimiento celular se controló cada dos o tres días mediante recuento en una cámara de Malassez y adiciones de las cantidades necesarias de medio fresco.

\section{Preparación de los distintos estímulos}

\subsection{Inducción de la apoptosis y necrosis celular en células Jurkat y PMN}

Las células Jurkat se resuspendieron a una concentración de $1 \times 10^{6}$ células $/ \mathrm{ml}$ en medio RPMI 1640 suplementado con $2 \mathrm{mM}$ de L-glutamina y $100 \mathrm{U} / \mathrm{ml}$ de penicilina/estreptomicina, desprovisto de FBS para favorecer la apoptosis. Para la inducción de la apoptosis se utilizaron dos tratamientos distintos: $10 \mu \mathrm{M}$ camptotecina y $0.5 \mu \mathrm{g} / \mathrm{ml}$ estaurosporina, durante 4 y 3 horas, respectivamente. El primer compuesto actúa a nivel del ADN e inhibe la actividad de la topoisomerasa I (Pizzolato y Saltz, 2003) y la estaurosporina induce la apoptosis por activación de la caspasa-3 (Han-Jung et al., 2000). Los PMN apoptóticos se obtuvieron mediante incubación a $37^{\circ} \mathrm{C}$ durante $24 \mathrm{~h}$ en el medio descrito anteriormente suplementado con Hepes $10 \mathrm{mM}$ para evitar la acidificación del medio. La necrosis de las células Jurkat se logró mediante congelación y descongelación. El porcentaje de apoptosis y necrosis se determinó por citometría de flujo. En el caso de las células Jurkat se utilizaron como control células no tratadas con los fármacos descritos en el párrafo anterior. 


\subsection{Preparación de partículas de zymosan A}

Las partículas de zymosan A provienen de una preparación comercial de extractos de la pared de S. cerevisiae. Estas partículas se diluyeron en agua destilada a una concentración de $20 \mathrm{mg} / \mathrm{ml}$ agitando vigorosamente para conseguir una solución homogénea. La solución se hirvió durante 10 min y se dejó enfriar a temperatura ambiente. Seguidamente, se centrifugó a 2000 x g durante 5 min, se decantó el sobrenadante y el sedimento se lavó 3 veces con PBS estéril, pH 7,4. Por último, el sedimento se resuspendió en PBS y se almacenó a $-20^{\circ} \mathrm{C}$.

\section{- Unión de C3bi a las partículas de zymosan (opzonización)}

El zymosan A se incubó con suero humano fresco durante 20 min en agitación a $37^{\circ} \mathrm{C}$ y en una proporción de $1 \mathrm{ml}$ de suero por cada $3 \mathrm{mg}$ de zymosan. A continuación se centrifugó a $1000 \times \mathrm{g}$ durante 5 minutos y se lavó tres veces con PBS.

\subsection{Obtención de suero anti-ovoalbúmina}

Los anticuerpos de clase IgG se obtienen de la sangre de conejos previamente inmunizados mediante una inyección subcutanea de ovoalbúmina en adyuvante completo de Freud, seguida de inyecciones intramusculares de recuerdo con ovoalbúmina en solución salina. Una vez inmunizados, se extrae la sangre para obtener el suero e inactivarlo por calor a $56^{\circ} \mathrm{C}$ durante 30 minutos. Posteriormente, se almacena a $-20^{\circ} \mathrm{C}$ hasta su utilización para la preparación de los inmunocomplejos.

\section{- Preparación de inmunocomplejos de lgG-ovoalbúmina}

La cantidad de anticuerpo necesaria para formar los inmunocomplejos (IC) a equivalencia se determinó mediante el test de Heidelberg y Kendall. Para ello se mezclaron cantidades crecientes de anticuerpo con una cantidad fija de antígeno y se incubaron durante una hora a $37^{\circ} \mathrm{C}$ y durante toda la noche a $4^{\circ} \mathrm{C}$ para permitir la interacción del anticuerpo con los epítopos del antígeno y la precipitación de los complejos insolubles. Las muestras se centrifugaron, se lavaron con PBS y el precipitado final se resuspendió en $0.1 \mathrm{M} \mathrm{NaOH}$. La concentración de la proteína se midió mediante detección de la absorbancia a $280 \mathrm{~nm}$. De acuerdo con la 
estequiometría obtenida en la reacción de precipitación cuantitativa se formaron los IC y se lavaron con PBS estéril.

\section{Citometría de flujo}

\subsection{Ensayo de expresión de receptores en la membrana plasmática de células mononucleares}

Para el estudio de la expresión de los diferentes receptores, se utilizaron $5 \times 10^{5}$ células por condición. En el caso de los $M \varnothing$ es necesario proceder al raspado de la placa para poder realizar su recuento y distribución, debido a que se mantienen adheridos a la placa de cultivo. Las células se centrifugaron a $350 \mathrm{x}$ g, durante 5 minutos y el precipitado se resuspendió en 100 $\mu$ de un tampón con PBS $1 \%(\mathrm{p} / \mathrm{v})$ de BSA y $0.1 \%(\mathrm{p} / \mathrm{v})$ de azida sódica. Posteriormente, se añadieron $0.5 \mu \mathrm{g}$ del anticuerpo respectivo y se incubaron durante 45 minutos en hielo. Las células incubadas con los anticuerpos marcados con FITC se lavaron con el tampón descrito anteriormente y se fijaron en una solución de PBS que contenía formaldehido al $0.1 \%$ para su análisis. En el caso de las células incubadas con los anticuerpos que no estaban marcados con FITC, la inmunofluorescencia se determinó indirectamente incubando durante 45 minutos a $4^{\circ} \mathrm{C}$ con un anticuerpo secundario marcado con FITC que reconoce al anticuerpo primario. Transcurrido los 45 minutos, se lavaron y fijaron para el estudio por citometría de flujo usando el citómetro Gallios (Beckman Coulter). Los resultados se analizaron mediante los software Kaluza ${ }^{\circledR}$ versión 1.1 y FlowJo.

\subsection{Análisis de las células apoptóticas y necróticas}

La apoptosis se puede detectar a partir de la cuantificación de los residuos de PS expuestos en la cara externa de la membrana plasmática como resultado de la pérdida de la asimetría. En presencia de $\mathrm{Ca}^{2+}$, la anexina-V tiene alta afinidad por la PS y cuando está conjugada con isotiocianato de fluoresceína (FITC) emite fluorescencia verde a $450 \mathrm{~nm}$ tras excitación lumínica. Las fases tardías de la apoptosis y la necrosis son detectables porque la membrana plasmática en estas fases se hace permeable y permite la entrada de moléculas extracelulares como el ioduro de propidio (IP), un fluoróforo que se intercala en los ácidos nucleicos y emite fluorescencia a $630 \mathrm{~nm}$ cuando se excita $488 \mathrm{~nm}$. 
Las células, a la concentración de $1 \times 10^{6}$ de células $/ \mathrm{ml}$ de cada tipo, se lavaron e incubaron con el tampón de unión a la anexina-V (10 mM Hepes, $140 \mathrm{mM} \mathrm{NaCl}, 2.5 \mathrm{mM} \mathrm{CaCl}$, pH 7.4). A continuación se resuspendieron en $100 \mu \mathrm{l}$ del mismo tampón suplementado con $2 \mu \mathrm{l}$ de anexina-V/FITC y $2 \mu \mathrm{g} / \mathrm{ml}$ de IP. Posteriormente, se incubaron durante 15 minutos en hielo en la oscuridad. Trascurrido este tiempo, se lavaron en el tampón de unión a la anexina-V y se resuspendieron en $500 \mu \mathrm{l}$ del mismo medio. El análisis de las muestras se realizó en el citómetro de flujo Gallios. Las células que presentaron un fenotipo positivo para anexina- $V$ y negativo para IP se consideraron como CA en fase temprana. La tinción doble con anexina-V/FITC e IP permitió diferenciar las células en una fase de apoptosis temprana de las células en apoptosis tardía, puesto que las células en esta fase captan tanto la anexina V-FITC como el IP (Figura 14).
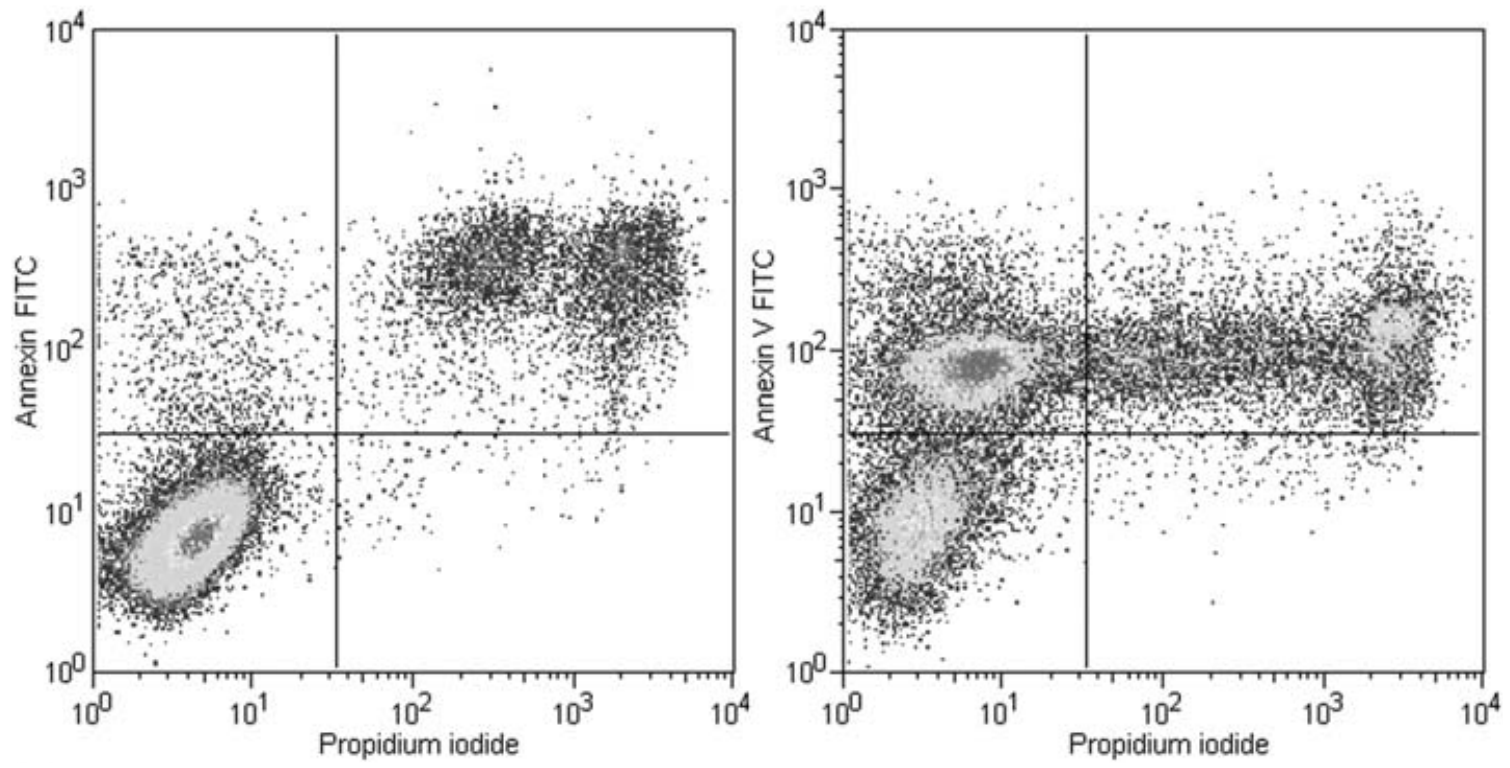

Figura 14: Captación de IP (eje $\mathrm{x}$ ) y Anexina V (eje y) por células controles y CA. En el panel de la izquierda se muestran las células viables, negativas para Anexina-V e IP (cuadrante inferior izquierdo). En el panel de la derecha se muestran las CA marcadas con Anexina-V pero no con IP, como son las que se observan en el cuadrante superior izquierdo. Las células en fase de apoptosis tardía son positivas tanto para Anexina-V como para IP (cuadrantes superiores derechos). En los cuadrantes inferiores derechos se muestran las células necróticas positivas para IP y negativas para Anexina-V (Macey, 2007).

\subsection{Detección de cuerpos lipídicos}

Las $C D$ a la concentración de $2 \times 10^{6}$ se incubaron con células Jurkat en la proporción de cinco CA por cada CD. La concentración de zymosan utilizada de forma general fue de $1 \mathrm{mg} / \mathrm{ml}$. Tras la incubación, las células se centrifugaron a $6000 \times \mathrm{g}$ a $4^{\circ} \mathrm{C}$, durante 30 segundos, se eliminó el sobrenadante y se resuspendieron en $400 \mu$ de PBS que contenía 1\% (p/v) BSA y 
0,1\% (p/v) azida sódica. El marcaje de las CD se hizo con anti-CD206 a la concentración de 10 $\mu \mathrm{g} / \mathrm{ml}$ durante 45 minutos en hielo, para distinguirlas de las células Jurkat que no expresan este receptor. Posteriormente, las células se incubaron con una mezcla de anticuerpo secundario conjugado con Ficoeritrina (PE) y $1 \mu \mathrm{g}$ de BODIPY ${ }^{\circledR}$ (Invitrogen), por cada 1 × $10^{6}$ células durante 30 minutos a $37^{\circ} \mathrm{C}$ en la oscuridad y se fijaron con $1 \%(\mathrm{v} / \mathrm{v})$ de formaldehido (Mattos et al., 2010) en $500 \mu$ l de PBS, para su análisis en el citómetro de flujo. La inducción de los cuerpos lipídicos se midió en el canal de FL1 y se expresó como la intensidad media de fluorescencia (MFI). Las muestras se analizaron usando el software Kaluza ${ }^{\circledR}$ para cuantificar el análisis de los histogramas.

\section{Determinación de los niveles de secreción de citoquinas y de otros mediadores anti-inflamatorios}

Mediante la técnica ELISA se cuantificó la producción de citoquinas siguiendo las instrucciones del fabricante. Se utilizaron kits comerciales de Amersham (IL-10), R\&D (IL-23 y TGF $\beta$-1), Thermo Scientific Pierce (IL-12 p70) y GE Healthcare (PGE 2 ). La densidad óptica (DO) de las muestras se leyó a $450 \mathrm{~nm}$ y la concentración se determinó mediante la extrapolación de los valores de DO obtenidos en una curva estándar y se expresaron como ng/106 células. Las gráficas se construyeron con el programa GraphPad Prism versión 4.

\section{Inmunodetección de proteínas}

\subsection{Obtención de lisados celulares}

Las células en suspensión se lavaron con PBS frío y se resuspendieron en el tampón de lisis (20 mM de Hepes, 10 mM de EGTA, 40 mM de $\beta$-glicerofosfato, $2.5 \mathrm{mM}$ de $\mathrm{MgCl}_{2}, 2 \mathrm{mM}$ de ortovanadato, $1 \mathrm{mM}$ de DTT, $1 \%$ de NP-40, $\mathrm{pH} 7,5)$ suplementado con los inhibidores de proteasas y fosfatasas descritos a continuación: $1 \mathrm{mg} / \mathrm{ml}$ leupeptina, $5 \mathrm{mg} / \mathrm{ml}$ aprotinina, $0.1 \mathrm{M}$ PMSF, $1 \mathrm{M} \mathrm{NaF}, 0.1 \mathrm{M}$ de PNPP y $0.1 \mathrm{M}$ DTT. Para la obtención de los extractos proteicos de las células adheridas se lavaron las placas dos veces con PBS frío y se rasparon en presencia del tampón de lisis TNE 1x (40 mM Tris pH 7.5, 150 mM NaCl, 10 mM EDTA, 1 \% Nonidet P-40) suplementado con los inhibidores de proteasas y fosfatasas indicados anteriormente.

El lisado se mantuvo durante 30 minutos en hielo, con agitación cada 10 minutos en 
vórtex. Finalmente, se centrifugó a 10.000 x g durante 10 minutos a $4^{\circ} \mathrm{C}$ para obtener el sobrenadante. La cuantificación de la concentración de la proteína se determinó mediante el método de Bradford (1976), que se basa en un desplazamiento del máximo de absorción (entre 465-595 nm) del colorante azul de Coomassie G-250 unido a las proteínas. La concentración de las proteínas se determinó midiendo la absorbancia a $595 \mathrm{~nm}$ en un espectrofotómetro con la ayuda de una curva patrón construida con BSA. La medición se realizó con un colorante comercial mezclando $1 \mu \mathrm{l}$ de la muestra, $800 \mu \mathrm{l}$ de la solución colorante y $200 \mu \mathrm{l}$ de $\mathrm{H}_{2} \mathrm{O}$ destilada estéril. Para la realización de la electroforesis se añadió a las muestras tampón de Laemmli 5X (60 mM Tris, 10\% glicerol (v/v), 2\% SDS (p/v) y 0.002\% azul de bromofenol, pH 6.8) suplementado con $20 \mathrm{mM}$ de DTT. Posteriormente, las muestras fueron hervidas durante 5 minutos y utilizadas para la inmunodetección por Western Blot.

\subsection{Separación de extractos nucleares y citosólicos}

La separación de los extractos nucleares de los citosólicos se realizó utilizando el Nuclear Extract Kit (Active Motif) según las instrucciones del fabricante. La valoración de la concentración de las proteínas se realizó por el método de Bradford y para la detección de CRTC2/TORC2, PPAR- $\gamma$ y PBX1 se utilizaron anticuerpos de Santa Cruz Biotechnology Inc. Como control de carga de proteína nuclear se usó la detección de TATA box-binding protein (TBP). Para los estudios de co-inmunoprecipitación de proteínas nucleares se utilizó el Nuclear Complex kit Co-IP de Active Motif. La inmunoprecipitación se llevó a cabo con anticuerpo antifosfo-CREB (Ser133) de Millipore y la detección de CRTC2/TORC2 y PBX1 se realizó con los anticuerpos mencionados anteriormente.

\subsection{Electroforesis en geles de acrilamida e inmunodetección de proteínas}

Las muestras se sometieron a electroforesis en gel de poliacrilamida en condiciones desnaturalizantes y reductoras según el procedimiento descrito por Laemmli (1970). El tampón de electroforesis estaba compuesto por $25 \mathrm{mM}$ Tris, $0.2 \mathrm{M}$ glicina y $1 \%(\mathrm{p} / \mathrm{v})$ SDS y los geles utilizados se prepararon con un $10 \%$ de acrilamida. La cantidad de proteína cargada se encontraba en el rango 50-100 $\mu \mathrm{g}$ y los estándares de proteínas utilizados fueron el Low Range y Kalidoscope, ambos de Bio-Rad. 
Las proteínas se transfirieron a membranas de nitrocelulosa utilizando el sistema de transferencia de Bio-Rad en condiciones húmedas durante 90 minutos a $100 \mathrm{~V}$. El tampón de transferencia contenía $25 \mathrm{mM}$ de Tris, $0.2 \mathrm{M}$ de glicina, $20 \%$ de metanol y $10 \%$ de SDS. Las membranas transferidas se bloquearon durante 2 horas a temperatura ambiente en agitación lenta con $5 \%$ (p/v) de leche desnatada en polvo disuelta en TTBS (2 M Tris/ $\mathrm{HCl}, 135 \mathrm{mM} \mathrm{NaCl}$, $0.05 \%$ (v/v) de Tween-20, pH7.6) o 5\% de BSA en los casos en los que las proteínas de la leche pudiesen interferir con la especificidad del anticuerpo. Para la inmunodetección, las membranas se incubaron con el anticuerpo primario diluido en la solución de bloqueo durante toda la noche a $4^{\circ} \mathrm{C}$. Al día siguiente se realizaron 3 lavados de 10 minutos y se incubaron con el anticuerpo secundario conjugado con peroxidasa de rabano excitable con el kit de quimioluminiscencia ECL de Amersham. La exposición en las películas auto-radiográficas se reveló en el equipo Curix de AGFA. La inducción de COX-2 se detectó usando anticuerpos de Santa Cruz Biotechnology Inc. El control de carga $\beta$-actina se detectó con anticuerpo de Sigma.

\section{Ensayo de liberación de ácido araquidónico}

En este ensayo se utilizaron placas de cultivo de 6 pocillos que contenían $1 \times 10^{6} \mathrm{CD}$. Las células se incubaron en medio RPMI 1640 sin suero con $0.25 \%$ (p/v) de BSA y $0.2 \mu \mathrm{Ci} / \mathrm{ml}$ de ácido araquidónico marcado con tritio $\left(\left[{ }^{3} \mathrm{H}\right] \mathrm{AA}\right)$ durante 5 horas a $37^{\circ} \mathrm{C}$, tiempo indispensable para una eficiente incorporación de [3H]AA en los fosfolípidos de membrana. Al día siguiente, las células se lavaron 2 veces con una solución que contiene $0.25 \%(\mathrm{p} / \mathrm{v})$ de BSA deslipidada disuelta en PBS y se estimularon en medio de cultivo sin suero, pero suplementado con BSA deslipidada al 1\%. Transcurrido el tiempo de estimulación, el medio se recogió en tubos Eppendorf y se centrifugó para obtener las células en suspensión. Posteriormente, se tomaron $0.5 \mathrm{ml}$ de sobrenadante y, paralelamente, se añadieron $0.5 \mathrm{ml}$ de Triton- $\mathrm{X}-100$ al $0.1 \%$ a las células y se recogió el lisado. La radioactividad presente en el sobrenadante y en los lisados celulares se determinó mediante centelleo líquido y se expresó como porcentaje del [ $\left.{ }^{3} \mathrm{H}\right] \mathrm{AA}$ incorporado en los fosfolípidos celulares. La determinación se realizó en un equipo LS 6500 Multi-Purpose Scintillation Counter (Beckman Coulter). 


\section{Análisis a nivel transcripcional}

\subsection{Extracción del ARN total}

Para la extracción del ARN total de las células se empleó el método de extracción fenólica con TRIzol ${ }^{\circledR}$ (Invitrogen) que consiste en una solución monofase de fenol y tiocianato de guanidina que permite mantener la integridad del ARN por la inhibición de la actividad de las RNAsas mientras se lisan las células y se desnaturalizan los componentes celulares durante el proceso de homogenización.

La extracción se llevó a cabo añadiendo $1 \mathrm{ml}$ de TRIzol ${ }^{\circledR}$ por cada $5-10$ × $10^{6}$ de células adheridas en placas de $100 \mathrm{~mm}$ de diámetro. Para obtener una solución homogénea, se rasparon las células y se pasaron a un tubo al que se añadieron $200 \mu \mathrm{l}$ de cloroformo bajo agitación vigorosa. Posteriormente, se centrifugó a $12.000 \times \mathrm{g}$ durante 15 minutos a $4^{\circ} \mathrm{C}$, obteniéndose 2 fases: la acuosa con el ARN y la orgánica con las proteínas y el ADN. A la fase acuosa se añadieron $250 \mu \mathrm{l}$ de isopropanol y $250 \mu \mathrm{l}$ de una solución acuosa de sales $(0.8 \mathrm{M}$ citrato sódico, $1.2 \mathrm{M} \mathrm{NaCl}$ ), dado que las muestras podían contener gran cantidad de polisacáridos procedentes del zymosan. Esta mezcla se centrifugó a $12.000 \mathrm{xg}$, durante 10 minutos a $4^{\circ} \mathrm{C}$ y el precipitado, que contiene el ARN, se lavó con EtOH al $75 \%$ en $\mathrm{H}_{2} \mathrm{O}-\mathrm{DEPC}$, las muestras se resuspendieron con $12-15 \mu$ de $\mathrm{H}_{2} \mathrm{O}$-DEPC y se almaceron a $-80^{\circ} \mathrm{C}$. La cuantificación del ARN se realizó en un NANO DROP, que aporta información acerca de la concentración y el grado de pureza del $A R N$, mediante la relación de la absorbancia $A_{260} / A_{280}$, considerándose valores aceptables entre 1,9 y 2 .

\subsection{Síntesis del ADN complementario}

La cantidad de $3 \mu \mathrm{g}$ de ARN se consideró adecuada para la reacción de la transcripción reversa, la cual genera una copia de la hebra de RNA en forma de ADN complementario (ADNc). Las muestras se diluyeron con un volumen de $11.1 \mu \mathrm{l}$ de $\mathrm{H}_{2} \mathrm{O}$-DEPC y se calentaron durante 10 minutos a $68^{\circ} \mathrm{C}$ para permitir la disociación del ARN. A cada muestra se le añadió la mezcla de:

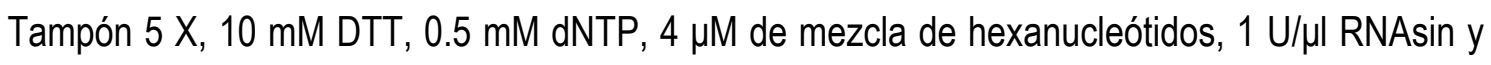
$10 \mathrm{U} / \mu \mathrm{l}$ de transcriptasa inversa del virus de la leucemia murina (RT M-MLV) y posteriormente se incubaron durante una hora a $37^{\circ} \mathrm{C}$. El ADNc se almacenó a $-20^{\circ} \mathrm{C}$. 


\subsection{PCR cuantitativa en tiempo real}

Este tipo de PCR, denominada también PCR cuantitativa (Q-PCR), se basa en la detección continua del producto de amplificación durante el transcurso de la PCR, con la ayuda de un agente que aumenta su fluorescencia tras su unión al ADN de doble cadena, como el SyBr Green I Master (Roche). La cuantificación se realizó en el equipo de PCR LightCycler ${ }^{\circledR}$ sofware 480 (Roche) mediante la determinación del ciclo de la PCR en el que la amplificación comienza a ser exponencial y que se denomina ciclo umbral (CT, cycle thresold). La mezcla de la reacción estaba compuesta por el SyBr Green I Master, $0.2 \mathrm{nM}$ de cada cebador, $1.5 \mu \mathrm{l}$ de ADNc y $\mathrm{H}_{2} \mathrm{O}$ de grado PCR, en un volumen final de $20 \mu \mathrm{l}$. El análisis de las muestras se realizó por duplicado y las condiciones de la amplificación se detallan en la tabla 1.

\begin{tabular}{c|c|c|c}
\hline Condición & Temperatura $\left({ }^{\circ} \mathrm{C}\right)$ & Tiempo & Ciclos \\
\hline Desnaturalización inicial & 95 & $10 \mathrm{~min}$ & $1 \mathrm{x}$ \\
\hline Desnaturalización & 95 & $30 \mathrm{seg}$ & \multirow{2}{*}{$40 \mathrm{x}$} \\
\cline { 1 - 3 } Hibridación & Variable para cada gen & $1 \mathrm{~min}$ & \multirow{2}{*}{$1 \mathrm{x}$} \\
\hline Elongación de los cebadores & 72 & $1 \mathrm{~min}$ & \\
\hline Elongación final & 72 & $10 \mathrm{~min}$ & $1 \mathrm{x}$ \\
\hline Preservación & 4 & $\infty$ &
\end{tabular}

Tabla 1: Condiciones generales de la amplificación por PCR a tiempo real.

La curva de disociación se obtuvo una vez finalizada la reacción, midiendo la fluorescencia de emisión para el SyBr Green durante el aumento gradual $\left(0.2^{\circ} \mathrm{C} /\right.$ segundo) de la temperatura de $65^{\circ} \mathrm{C}$ a $95^{\circ} \mathrm{C}$ provocando la desnaturalización de los productos de PCR y, por ende, la separación del SyBr Green con la consiguiente pérdida de la fluorescencia. Para comprobar la eficiencia de la PCR se amplificó en todas las muestras el gen de la gliceraldehido3-fosfato dehidrogenasa (gapdh) por su expresión constitutiva. Los resultados se expresan como la media de los CT del gen que se analiza con respecto a los CT de gapdh.

Los cebadores se diseñaron sobre las secuencias humanas obtenidas del GenBank flanqueando los intrones para evitar la detección de contaminación por ADN genómico (Tabla 2). El ensayo de las isoformas A y $B$ de dectin-1 se realizó con un cebador antisentido en el exón 5' y la identificación de las isoformas se reveló por la secuenciación del producto de la PCR. 


\begin{tabular}{|c|c|c|}
\hline Gen & Secuencia sentido y antisentido (5'-3') & № GenBank \\
\hline CD206 & $\begin{array}{l}\text { GCTGAACCTGGAAAAAGCTG } \\
\text { ACGAAGCCATTTGGTAAACG }\end{array}$ & NM_002438 \\
\hline$D C-S I G N$ & $\begin{array}{l}\text { AGGTCCCCAGCTCCATAAGT } \\
\text { TCTCTGGAAGCTCACCCACT }\end{array}$ & NM_021155 \\
\hline dectin1exón 1 & GGGCTCTCAAGAACAATGGA & \multirow{3}{*}{ AF400596 } \\
\hline dectin1 exón 6 & TTGGAGATGGGTTTTCTTGG & \\
\hline dectin1 exón 5 & CCCAGAGCCATGGTACCTC & \\
\hline gapdh & $\begin{array}{l}\text { GTCAGTGGTGGACCTGACCT } \\
\text { AGGGGAGATTCAGTGTGGTG }\end{array}$ & NM_002046.3 \\
\hline il-10 & $\begin{array}{l}\text { GAGAACAGCTGCACCCACTT } \\
\text { GGCCTTGCTCTTGTTTTCAC }\end{array}$ & NM_000572.2 \\
\hline$T L R-2$ & $\begin{array}{l}\text { GCCAAAGTCTTGATTGATTGG } \\
\text { TTGAAGTTCTCCAGCTCCTG }\end{array}$ & NM_003264 \\
\hline
\end{tabular}

Tabla 2: Secuencia de cebadores utilizados para Q-PCR y el código de acceso de las secuencias en GenBank.

\subsection{Análisis de la expresión génica mediante PCR}

La amplificación del ADNc específico de algunos genes de interés se realizó por PCR convencional. Al igual que los cebadores para la Q-PCR, los empleados en esta técnica también se diseñaron sobre las secuencias humanas obtenidas del GenBank en regiones que flanquean los intrones para evitar la contaminación por el ADN genómico (Tabla 3).

\begin{tabular}{c|c|c}
\hline Gen & Secuencia sentido y antisentido (5'-3') & No GenBank $^{\circ}$ \\
\hline s1p1/edg1 & $\begin{array}{c}\text { TATCAGCGCGGACAAGGAGAACAG } \\
\text { ATAGGCAGGCCACCCAGGATGAG }\end{array}$ & NT_032977.9 \\
\hline s1p2/edg5 & $\begin{array}{c}\text { TATCAGCGCGGACAAGGAGAACAG } \\
\text { ATAGGCAGGCCACCCAGGATGAG }\end{array}$ & NW_001838483.2 \\
\hline s1p3/edg3 & $\begin{array}{l}\text { CTTGGTCATCTGCAGCTTCATC } \\
\text { TCATTGTCAAGTGCCGCTCGAT }\end{array}$ & NT_008470.19 \\
\hline s1p4/edg6 & $\begin{array}{c}\text { GAGAGCGGGGCCACCAAGAC } \\
\text { GGTTGACCGCCGAGTTGAGGAC }\end{array}$ & NT_011255.14 \\
\hline s1p5/edg8 & $\begin{array}{l}\text { ACAACTACACCGGCAAGCTC } \\
\text { GCCCCGACAGTAGGATGTT }\end{array}$ & NW_001838483.2 \\
\hline
\end{tabular}

Tabla 3: Secuencia de cebadores utilizados para PCR y código de acceso en GenBank. Los cebadores s1p1, s1p2 y s1p3 fueron reportados por Idzko et al., 2002. EDG: endotelial differentiation gene designación inicial de los receptores de S1P. 
La reacción de PCR se llevó a cabo con $3 \mu \mathrm{l}$ del ADNc mezclado con los reactivos para PCR (1.5 mM MgCl $2,0.1 \mathrm{mM}$ dNTP, $10 \mu \mathrm{M}$ de cada cebador, $0.05 \mathrm{U} / \mu \mathrm{l}$ de Taq polimerasa, 0.5 $\mu \mathrm{M}$ de cada oligonucleótido específico) y $\mathrm{H}_{2} \mathrm{O}$ estéril hasta completar un volumen final de $25 \mu$. La reacción se realizó en el termociclador MiniCycler de MJ Research y las condiciones generales se describen en la Tabla 4.

\begin{tabular}{c|c|c|c}
\hline Condición & Temperatura $\left({ }^{\circ} \mathrm{C}\right)$ & Tiempo (minutos) & Ciclos \\
\hline Calentamiento & 94 & 5 & $1 \mathrm{x}$ \\
\hline Desnaturalización & 94 & 1 & \multirow{3}{*}{$30-35 \mathrm{x}$} \\
\cline { 1 - 3 } Hibridación & Variable para cada gen & 1 & \\
\hline Elongación de los cebadores & 72 & 1 & $1 \mathrm{x}$ \\
\hline Elongación final & 72 & 10 & $1 \mathrm{x}$ \\
\hline Preservación & 4 & $\infty$ &
\end{tabular}

Tabla 4: Condiciones generales de la amplificación por PCR.

Como control de la eficiencia de la reacción y método de normalización semicuantitativa se utilizó el gen de la gapdh. Los productos de la PCR se identificaron mediante electroforesis en geles de agarosa y tinción con bromuro de etidio o con GelRed nucleic acid stain (Biotium). El análisis de los geles y la cuantificación de las bandas se realizó con el software de análisis de imagen Gel Doc.

\section{Cuantificación de la esfingosina-1-fosfato liberada de las células apoptóticas}

\subsection{Extracción de esfingosina-1-fosfato}

La extracción de la S1P se llevó a cabo siguiendo el método descrito por Weigert y col. (2006), que consiste en extraer lípidos del sobrenadante de $5 \times 10^{6}$ células sometidas a apoptosis. Las células en cultivo se someten a centrifugación y después se añade al sobrenadante un volumen igual de clororformo/ $\mathrm{HCl}(50: 1, \mathrm{v} / \mathrm{v})$, repitiéndose el proceso dos veces más. La fase orgánica resultante se evaporó a sequedad y se resuspendió en $1 \mathrm{ml}$ de etanol para eliminar el excedente de proteínas mediante centrifugación. Después de la centrifugación se recolectaron entre $350-500 \mu \mathrm{l}$ y se procedió a una nueva evaporación. El residuo sólido se 
resuspendió en $150 \mu \mathrm{l}$ de metanol:agua en la proporción 95:5 (v/v) y se almacenó a $-80^{\circ} \mathrm{C}$ hasta su posterior análisis.

\subsection{Cuantificación por espectrometría de masas}

La cuantificación de S1P se realizó mediante la técnica de cromatografía líquida acoplada a espectrometría de masas (UPLC-QToF-MS, ultraperformance liquid chromatography interfaced to a time-of-flight mass spectrometer) siguiendo el método reportado por Berdyshev y col. (2005) con algunas modificaciones. Para la separación cromatográfica se utilizó el Acquity UPLC System (Waters, Milford, USA) equipado con una columna Adquity BEH C18 $1.7 \mu \mathrm{m}, 2.1 \mathrm{x}$ $50 \mathrm{~mm}$ que se conecta directamente en la fuente de electrospray del espectrómetro de (SYNAPT HDMS G2, Waters). Se utilizó un gradiente de dos disolventes para la separación de los compuestos. La composición del solvente A fue: metanol:agua:ácido fórmico (50:50:0.5, v/v/v); y la del solvente B: metanol:acetonitrilo:ácido fórmico (59:40:0.5, v/v/v). Ambos solventes contenían $5 \mathrm{mM}$ de formiato de amonio a pH, 3.2. En el sistema de cromatografía se inyectaron alícuotas de 7,5 $\mu$ l.

Por espectrometría de masas se detectaron los componentes como iones positivos mediante el método $\mathrm{MS}^{\mathrm{E}}$, que permite detectar simultáneamente analitos a través de funciones de mínima (análisis completo) y máxima energía (fragmentación en 20-30V) con la fragmentación parcial del ion. Para la cuantificación se obtuvo la curva patrón mediante el estándar externo de S1P de masa (379.2487 Da) y se realizó de acuerdo con el área de los picos de la cromatografía obtenidos mediante el cromatograma de ion extraído (EIC extracted ion chromatogram). El fragmento de $264.269 \mathrm{~m} / \mathrm{z}$ de S1P se obtuvo en función de máxima energía.

\section{Expresión de los datos a nivel estadístico}

Los estudios se realizaron al menos tres veces con resultados similares. Los datos numéricos están representados como media \pm error estándar (ES). Los datos fueron analizados mediante Student's test con el sofware GraphPad Prism versión 4. Las diferencias fueron consideradas estadísticamente significativas para un valor de $p$ menor o igual a 0.05 . 

Resultados 


\section{Caracterización de los receptores implicados en el reconocimiento de los patrones fúngicos en células mononucleares humanas}

El microambiente y la diferenciación celular condicionan la expresión de receptores

La diferenciación de los monocitos depende de las citoquinas y factores de crecimiento presentes en el microentorno, puesto que éstos modulan la expresión génica. El M-CSF y el GMCSF asociado a la IL-4, se emplean habitualmente para inducir la diferenciación de los monocitos en $M \varnothing$ y $C D$, respectivamente. Los experimentos se realizaron a partir de monocitos aislados de sangre periférica y para la diferenciación a $M \varnothing$ se siguieron dos protocolos distintos: suero humano (MØSH), que posee de forma constitutiva una cierta cantidad de M-CSF, y diferenciación con FBS suplementado con $10 \mathrm{ng} / \mathrm{ml}$ de M-CSF (MØM-CSF). La diferencia más notable observada en la morfología de las células fue que los MØM-CSF presentaban una mayor tendencia a adquirir forma de huso (Figura 15, panel inferior).

Como se muestra en la Figura 15, en el caso de los $M \varnothing$ no se observaron diferencias significativas en la expresión de receptores que pudiese relacionarse con el empleo de los distintos protocolos. En ambos casos se observó un alto grado de expresión RM/CD206 y una expresión más reducida de dectin-1 y DC-SIGN. Siendo la expresión de dectin-2 y TLR-2 mayor en los MØM-CSF. En contraste, las CD presentaron una mayor expresión de DC-SIGN y dectin1, en concordancia con la conocida capacidad del GM-CSF e IL-4 para inducir la expresión de CLR (Willment et al., 2003). 


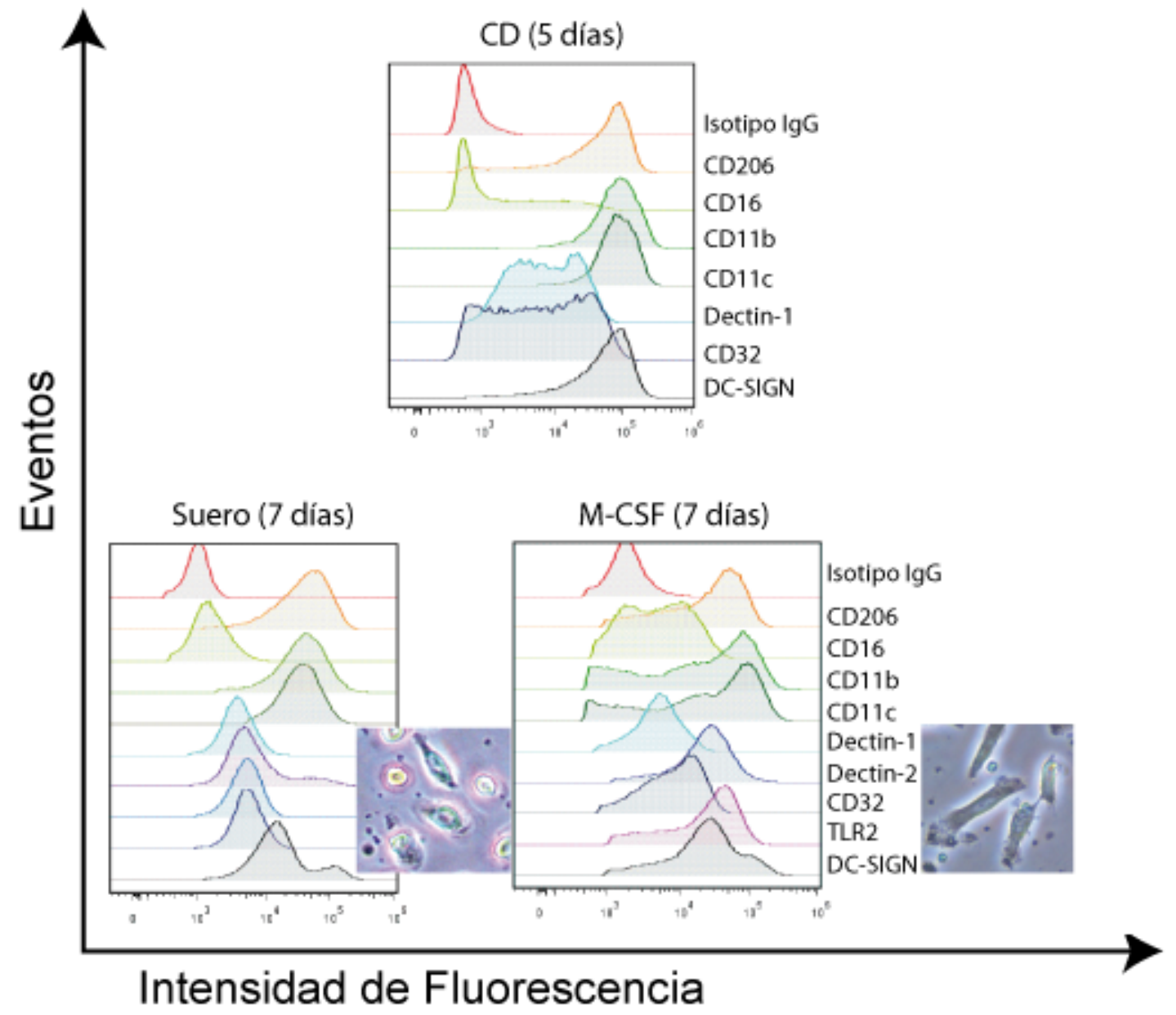

Figura 15. Receptores de membrana expresados en $C D$ y $M \varnothing$. La expresión se examinó por citometría de flujo con anticuerpos específicos en CD diferenciadas durante 5 días y en M $\varnothing$ tratados con SH y FBS + M-CSF durante 7 días. Los datos de citometría se procesaron mediante los software Kaluza ${ }^{\circledR}$ y FlowJo. Las gráficas son representativas de tres experimentos independientes con resultados similares.

\section{- Cuantificación de la expresión de los receptores por RT-PCR}

Puesto que la expresión de los CLR se caracteriza por un alto grado de empalme alternativo en las regiones codificantes del dominio de unión a carbohidratos, la región transmembrana y el cuello, es posible que los anticuerpos puedan reconocer isoformas que difieren en su capacidad para unir el ligando y responder al estímulo. Por este motivo, se analizó la expresión del ARNm de las distintas isoformas de dectin-1 por RT-PCR a tiempo real con cebadores diseñados en distintos exones (Tabla 2), que abarcan las porciones extracelulares e intracelulares y permiten detectar las distintas isoformas. El análisis reveló que la diferenciación con M-CSF potencia la expresión del ARNm de dectin-1 en mayor proporción que la diferenciación con suero, y que este incremento se debe a una mayor cantidad de las isoformas de A y B (Figura 16). 


\section{Dectin-1 200 DC-SIGN \\ Dectin-1 A y B CD206/Receptor de manosa

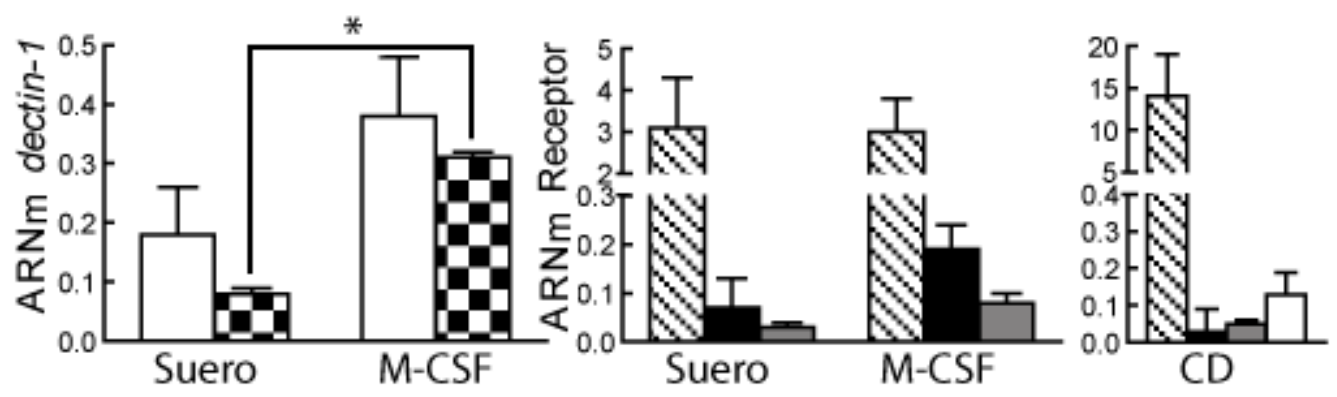

Figura 16. Cuantificación de la expresión del ARNm de los receptores implicados en el reconocimiento de hongos. La RT-PCR en tiempo real se llevó a cabo con cebadores para las distintas isoformas de dectin-1, DCSIGN, CD206 y TLR2. La identificación de las distintas isoformas de dectin-1 se realizó mediante la secuenciación del ADN obtenido en la RT-PCR. Los resultados se normalizaron mediante la expresión de gapdh y representan la media $\pm D E$ de cuatro experimentos independientes. *Indica $p<0.05$ para la comparación de la expresión de las isoformas $\mathrm{A}$ y $\mathrm{B}$ de dectin-1 entre los $\mathrm{M} \varnothing$ diferenciados con $\mathrm{SH}$ y los diferenciados con M-CSF.

El análisis del ARNm que codifica los receptores DC-SIGN, CD206 y TLR2 mostró que el ARNm de DC-SIGN presenta el mayor nivel de expresión en los tres tipos celulares, siendo mucho mayor la expresión en las CD y similar entre los distintos tipos de M $\varnothing$ (Figura 16). Tomados en conjunto, estos resultados indican que el proceso de diferenciación contribuye a un aumento de la expresión de las isoformas A y B de dectin-1 y de DC-SIGN, lo que favorece el reconocimiento de los patrones fúngicos.

\section{Análisis por citometría de flujo para detectar la externalización de la fosfatidilserina y el aumento de permeabilidad de la membrana en las células apoptóticas}

Con el fin de establecer un protocolo reproducible para la obtención de CA, las células Jurkat se trataron con $10 \mu \mathrm{M}$ de camptotecina durante 24 horas y se analizaron a las 4 y a las 24 horas. Como se muestra en la Figura 17, el máximo porcentaje de apoptosis (cuadrante superior izquierdo) se observó a las 4 horas con un $58.92 \%$ de células marcadas con anexina-V FITC. En las células tratadas durante 24 horas, sólo un $23.43 \%$ fueron positivas para la anexina- $V$, lo que se explica por un mayor número de células en apoptosis tardía, mientras que en las no tratadas sólo se observó un $0.92 \%$ de apoptosis temprana a las 4 horas y del $4.61 \%$ a las 24 horas. Este tratamiento, en el intervalo de tiempo en el que se ha estudiado, afecta poco a la permeabilidad 
de la membrana puesto que el número de células marcadas con ioduro de propidio fue muy reducido, como se muestra en el cuadrante inferior derecho de las gráficas. En consecuencia, para la realización de los experimentos se decidió utilizar células tratadas con camptotecina durante 4 horas, que en conjunto mostraron un grado de apoptosis temprana de entre un $30 \mathrm{y}$ $60 \%$, lo que indica que el procedimiento elegido para la inducción de apoptosis es reproducible y permite una generación adecuada de células en apoptosis temprana, con un reducido número de células viables y necróticas.

\section{4 horas}

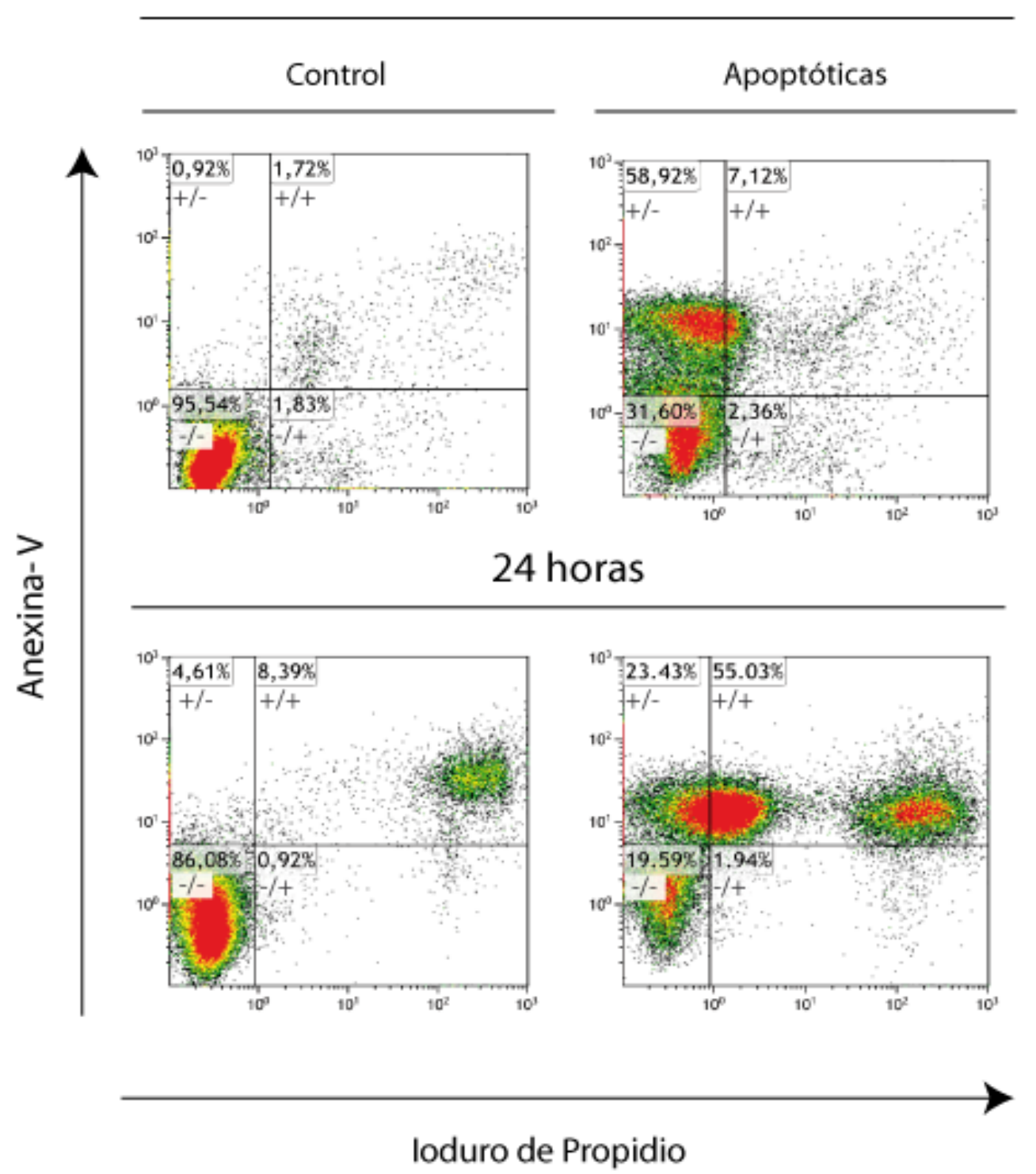

Figura 17: Captación de anexina-V e IP por células Jurkat. Control (células no tratadas) y células Jurkat tratadas con camptotecina para la inducción de apoptosis durante 4 horas y 24 horas. Cuadrantes inferiores izquierdos (-/-): células viables; cuadrantes superiores izquierdos (+/-): células en fase de apoptosis temprana; cuadrantes superiores derechos $(+/+)$ : células en fase de apoptosis tardía; cuadrantes inferiores derechos $(-/+)$ : células necróticas. 


\subsection{Inducción de apoptosis con estaurosporina}

Con el fin de analizar el efecto de otro procedimiento de inducción de apoptosis, las células Jurkat se trataron con $5 \mu \mathrm{g} / \mathrm{ml}$ de estaurosporina durante 3 horas (Weigert et al. 2006). El doble marcaje con anexina-V FITC e ioduro de propidio mostró la presencia de un $50.47 \%$ de células en apoptosis temprana y un $0.51 \%$ de células necróticas. En las células no tratadas se observaron porcentajes más bajos en los cuadrantes respectivos $(0.77 \%$ y $0.38 \%)$ (Figura 18 ). Análogamente al tratamiento con camptotecina, el porcentaje de células en apoptosis se mantuvo entre $30-60 \%$. Estas células fueron la fuente de CA para el estudio del efecto de la liberación de S1P por las células Jurkat sobre la producción de IL-10 en M $\varnothing$, como se describirá más adelante, dado que la comparación de nuestros resultados con los existentes en la literatura hace necesario el empleo de abordajes experimentales análogos.

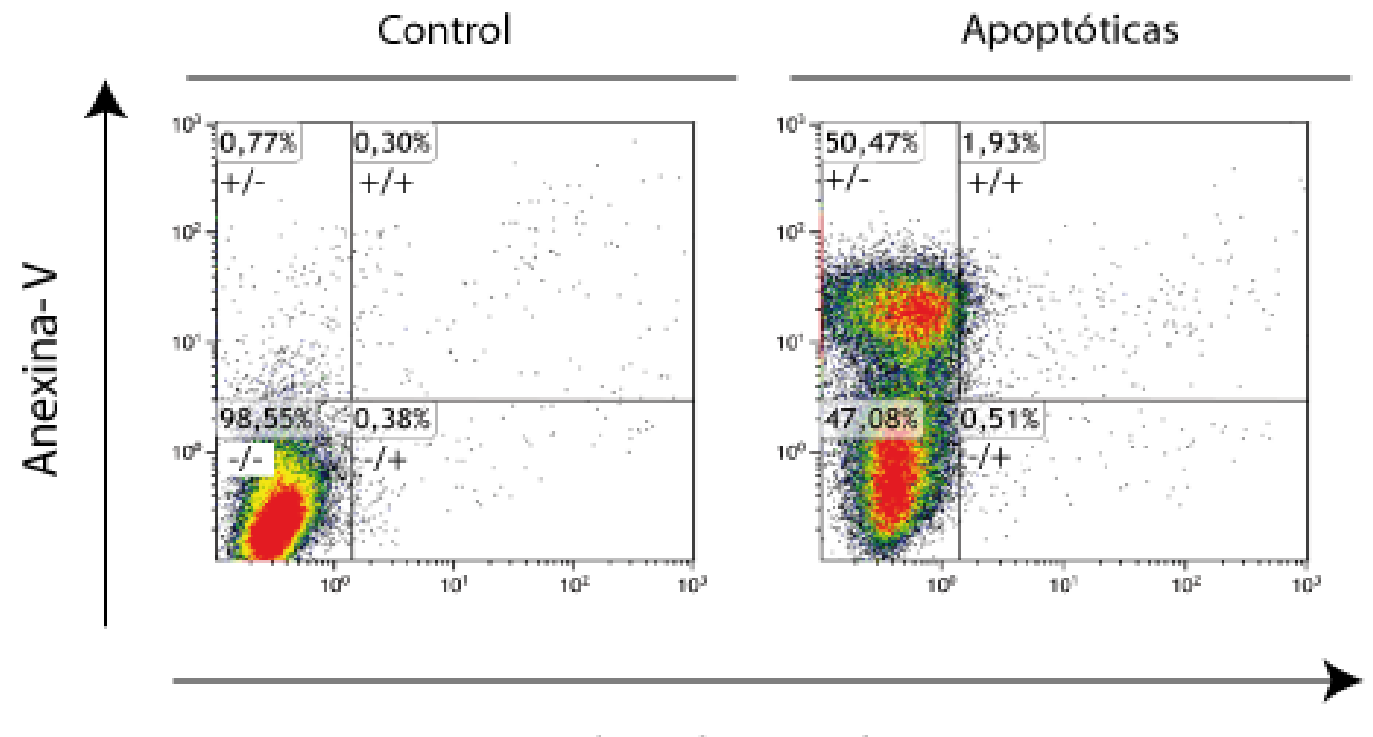

\section{loduro de Propidio}

Figura 18: Captación de Anexina-V e IP por células Jurkat. Células Jurkat control y tratadas con $5 \mu \mathrm{g} / \mathrm{ml}$ de estaurosporina durante 3 horas se analizaron por citometría de flujo para determinar el grado de apoptosis.

\subsection{Inducción de apoptosis en otra estirpe celular}

La apoptosis también se estudió en PMN ya que presentan apoptosis de forma constitutiva relacionada con su elevado ritmo de recambio celular. Puesto que la apoptosis no fue acelerada por ninguna señal pro-apoptótica, los experimentos requirieron tiempos de incubación más largos. Las células se incubaron a $37^{\circ} \mathrm{C}$ y se analizaron a las 0,24 y 48 horas. El 
mayor porcentaje de apoptosis se observó a las 24 horas (33.2\%), mientras que en las células recién aisladas (0 horas) y a las 48 horas el porcentaje fue similar, puesto que a este último tiempo predominaron las células que sufrieron necrosis (Figura 19). Estas células se utilizaron en los experimentos de inducción de COX-2 con la finalidad de determinar si los resultados obtenidos eran exclusivos de las células Jurkat o si, por contrario, se trata de una respuesta que también se puede observar en el caso de apoptosis inducida por otros procedimientos.

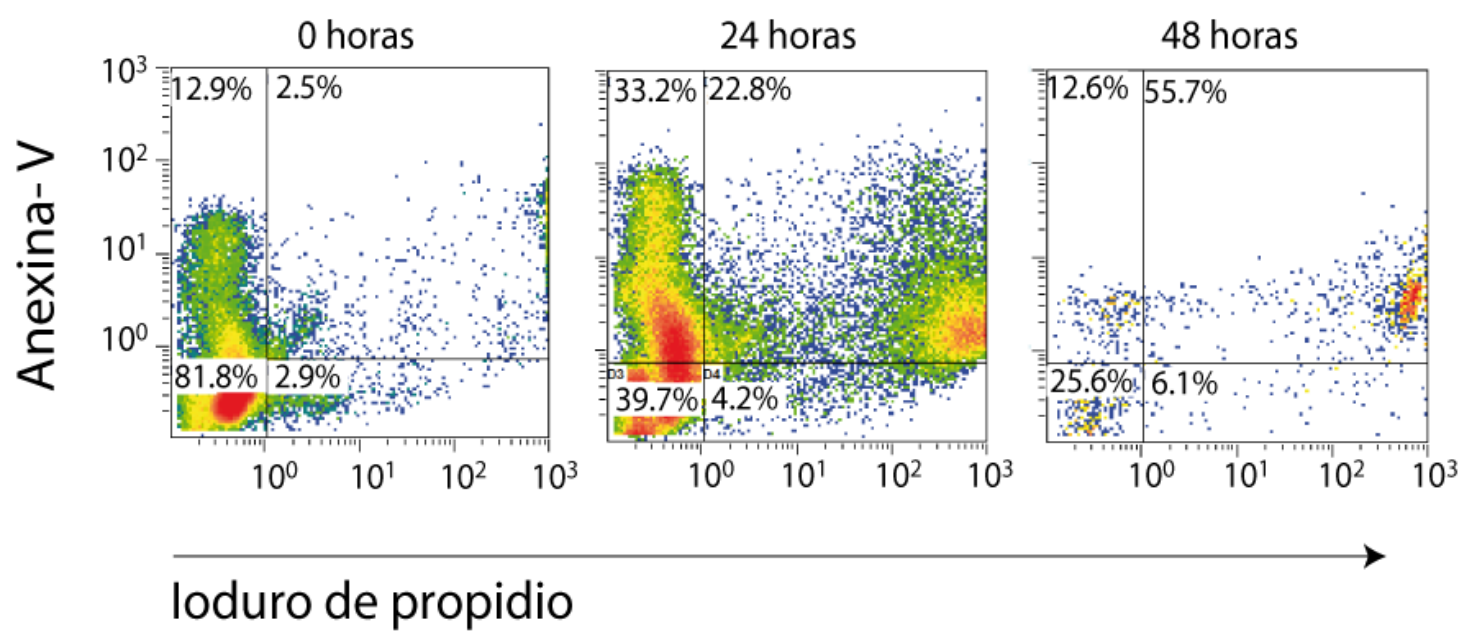

Figura 19: Captación de Anexina-V e IP por PMN recién aislados e incubados durante 24 y 48 horas a $37^{\circ} \mathrm{C}$ en medio RPMI tamponado con $10 \mathrm{mM}$ de Hepes.

\section{Efecto de la estimulación con patrones bacterianos y de la pared de los hongos sobre la producción de citoquinas por células dendríticas}

Se utilizaron CD inmaduras tratadas con zymosan y con la combinación de LPS + IFN- $\gamma$, que representa el estímulo pro-inflamatorio que mejor reproduce la composición del microentorno en las infecciones bacterianas. La Figura 20 muestra el patrón característico de producción de IL-10 e IL-12 p70 por el zymosan, que se caracteriza por una alta producción de IL-10 y una baja producción de IL-12 p70. Este resultado confirma que el zymosan es un potente inductor de IL10 y que tiene una capacidad reducida para estimular la producción de IL-12 p70, puesto que no se obtuvieron producciones superiores a $0.1 \mathrm{ng} / 10^{6}$ células. Por el contrario, la combinación de LPS e IFN- $\gamma$ produjo elevadas cantidades de IL-12 p70, lo que indicaría que esta combinación de estímulos reproduce fidedignamente los entornos inflamatorios in vivo, donde la presencia de productos bacterianos se complementa con la presencia de citoquinas pro-inflamatorias. Sorprendentemente, el empleo de LPS como único estímulo, incluso a elevadas 
concentraciones, produjo una escasa producción de IL-12 p70 a pesar de que la producción de IL-10 con este estímulo fue elevada.
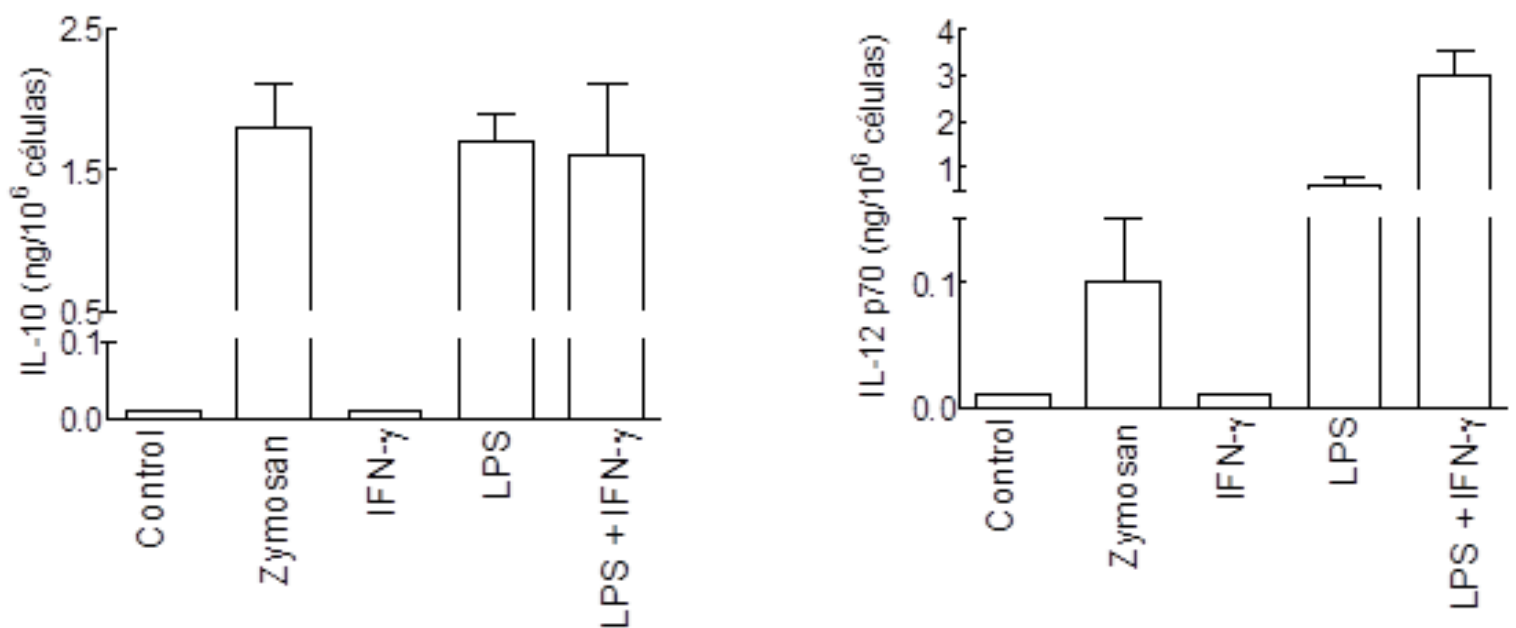

Figura 20: Producción de IL-10 e IL-12 p70 por CD incubadas en presencia de zymosan (1 mg/ml), IFN- $\gamma$ (1000 $\mathrm{U} / \mathrm{ml})$, LPS $(10 \mu \mathrm{g} / \mathrm{ml})$ y la combinación de estos estímulos. Las citoquinas liberadas al medio se cuantificaron en los sobrenadantes mediante ELISA tras 24 horas de incubación con los estímulos. Los datos representan media $\pm \mathrm{DE}$ de 6 experimentos independientes.

\subsection{Efecto de la adición de células Jurkat}

Con el objetivo de analizar si el reconocimiento de las CA puede influir en la polarización de la respuesta inmune, las CD se incubaron con células Jurkat vivas y apoptóticas, en presencia y ausencia de zymosan y LPS. Las CA fueron un débil estímulo para la liberación de citoquinas, cuando se analizó su efecto en el rango de 1 a 30 CA por CD (datos no mostrados), pero sí aumentaron el efecto del zymosan cuando se utilizaron en la proporción de 5 CA por cada CD. Estos experimentos, se realizaron añadiendo las CA al medio una hora antes de la adición de los estímulos anteriormente mencionados. La adición de CA produjo un aumento significativo de la producción de IL-10 inducida por el zymosan (Figura 21). 


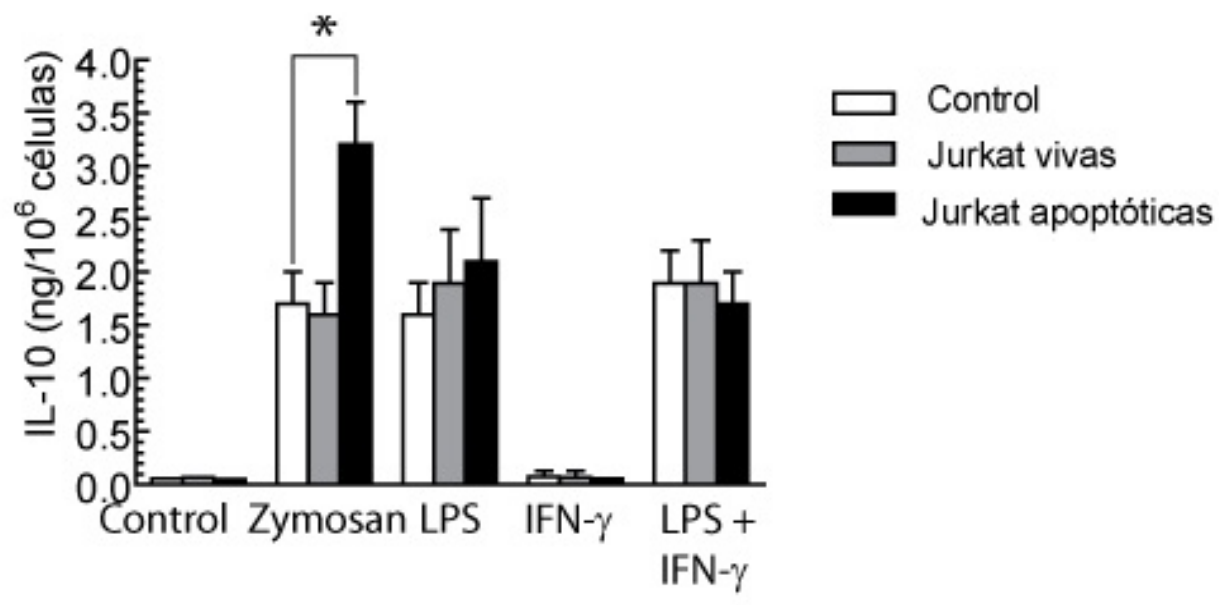

Figura 21: Efecto de las células Jurkat sobre la producción de IL-10 por las CD. Las CD se incubaron durante una hora con las CA y posteriormente se añadieron las concentraciones habituales de los estímulos durante 24 horas. La proporción de células Jurkat frente a las CD fue de 5:1. La concentración de IL-10 se midió en sobrenadantes. Los datos representan media \pm DE de 6 experimentos independientes. *Indica un valor de $p<0.05$ para la comparación entre el cultivo de CD y la pre-incubación de CD con CA.

Una vez estudiado el efecto sobre la producción de IL-10, se analizó la producción de IL12 p70. La presencia de las células Jurkat no modificó la producción de IL-12 p70 cuando éstas se utilizaron como único estímulo ni cuando se combinaron con zymosan y LPS + IFN $\gamma$. (Figura 22).

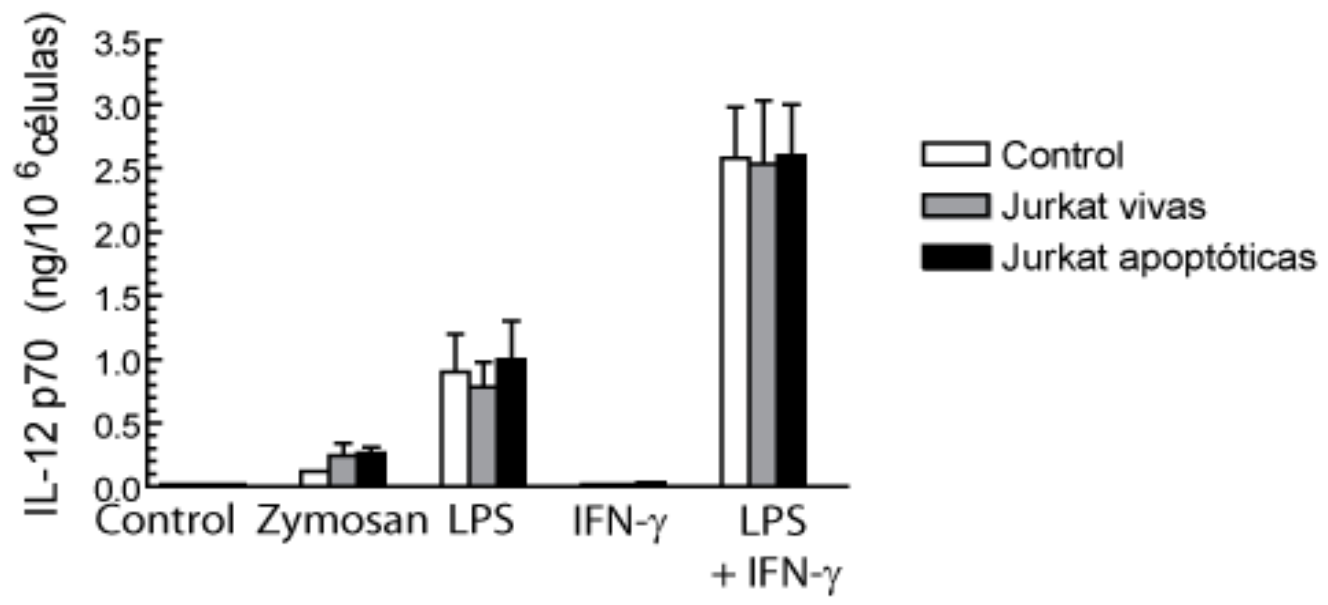

Figura 22: Efecto de las células Jurkat sobre la producción de IL-12 p70 por CD. Las concentraciones de los estímulos son las empleadas en las figuras 20 y 21. Los datos representan media \pm DE de 6 experimentos independientes.

En contraste con lo observado con la liberación de IL-10, la producción de IL-23 inducida por el zymosan disminuyó con la adición de las CA, sin embargo, las CA no modificaron el efecto de la combinación del LPS e IFN- $\gamma$ (Figura 23). 


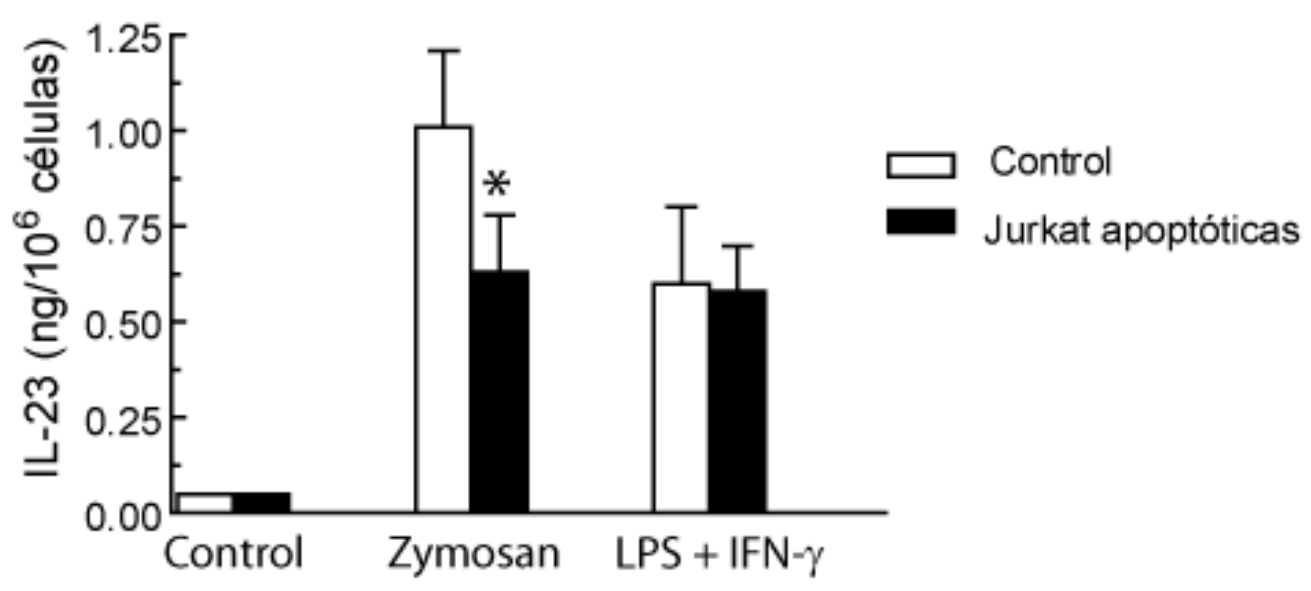

Figura 23: Producción de IL-23 por CD incubadas con células Jurkat apoptóticas, zymosan y LPS utilizando las mismas condiciones experimentales que las figuras anteriores. ${ }^{*}$ Indica un valor de $p<0.05$.

\subsection{Liberación de mediadores anti-inflamatorios}

Estudios previos han demostrado que el efecto anti-inflamatorio de las CA sobre los M $\varnothing$ puede deberse a la liberación de mediadores anti-inflamatorios como TGF- $\beta$ y de eicosanoides como PGE 2 (Fadok et al. 1998; Cvetanovic et al 2004; Freire-de-Lima et al, 2006). Estas moléculas pueden actuar por mecanismos autocrinos y paracrinos para suprimir la inflamación; sin embargo, sus mecanismos de acción en la mediación del efecto de las CA están escasamente definidos. En consecuencia, analizamos la posible producción de TGF- $\beta 1$ por las $\mathrm{CD}$ y $\mathrm{M} \varnothing \mathrm{SH}$ en respuesta a las CA. Las medidas se realizaron en ausencia de suero, para eliminar la interferencia debida al TGF- $\beta 1$ que pudiera estar presente en el mismo y los sobrenadantes obtenidos se sometieron a un tratamiento ácido y una neutralización inmediata para activar el TGF- $\beta 1$ latente a su forma inmunoreactiva. Las CD no mostraron producción significativa en respuesta a zymosan, CA y LPS, sin embargo, el zymosan opsonizado indujo una producción de $0.1 \mathrm{ng} / \mathrm{ml}$ de TGF- $\beta 1$ (datos no mostrados). Los experimentos realizados en $\mathrm{M} \varnothing \mathrm{SH}$ mostraron resultados distintos, puesto que las CA indujeron una producción significativa de TGF- $\beta 1$ tanto en presencia como en ausencia de los estímulos analizados (Figura 24). Estos resultados muestran las diferencias entre los $M \varnothing$ y las $C D$ para responder a los estímulos y concuerdan con lo referido por Fadok y col. (1998), quienes describen que la adición de CA incrementa la producción de TGF- $\beta 1$ inducida por zymosan y LPS en M $\varnothing$. 


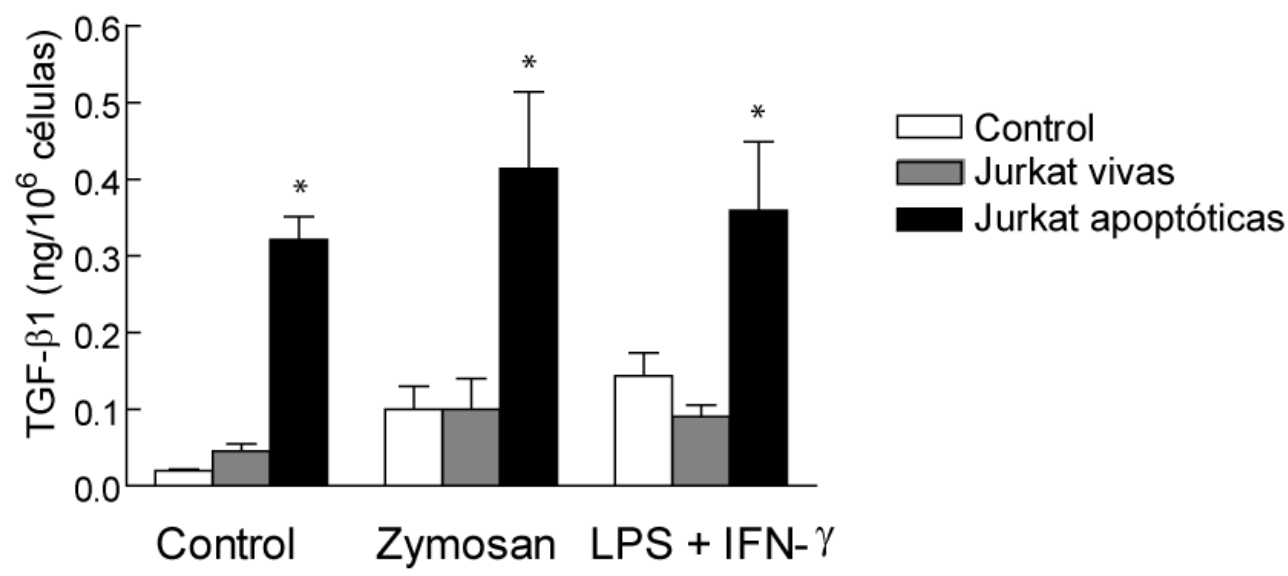

Figura 24: Producción de TGF- $\beta 1$ por M $\varnothing$ incubados con células Jurkat vivas y apoptóticas. Los estímulos se añadieron a las concentraciones habituales. Los datos representan media \pm E.S de 6 experimentos independientes. *Indica un valor de $p<0.05$ en comparación con los valores obtenidos en ausencia de CA.

\section{El papel de las opsoninas del suero sobre el reconocimiento de las células apoptóticas}

El suero contiene numerosas opsoninas cuya función es favorecer el contacto entre la superficie de las $\mathrm{CA}$ y los distintos receptores que se han implicado en su reconocimiento. Entre estas opsoninas, ocupan un papel importante aquéllas que se generan durante la activación del sistema del complemento, de tal manera que algunos autores han propuesto que el reconocimiento de las CA se debe a que éstas se recubren de C3bi, siendo esta molécula o los derivados de su procesamiento los verdaderos elementos reconocidos por los receptores de $M \varnothing$ y CD implicados en el desarrollo de la respuesta anti-inflamatoria (Mevorach et al., 1998; Amarilyo et al., 2010) (Mevorach et al., 1998; Amarilyo et al., 2010) y bloqueo del sistema NFкB (Amarilyo et al., 2010).

Para analizar el efecto del suero sobre la producción de IL-10, se comparó el efecto del suero humano normal $(\mathrm{SHn})$, como fuente de los factores del complemento, con el efecto del suero inactivado por calor (SHi) como fuente de otras opsoninas resistentes a la desnaturalización. La combinación de las CA con SHi incrementó notablemente la respuesta al zymosan, mientras que este efecto fue menos intenso en presencia de SHn. Este resultado sugiere que el efecto del suero depende de opsoninas distintas a C3bi. En contraste, la adición de suero no modificó la liberación de IL-10 por el LPS y LPS + IFN-y (Figura 25). 


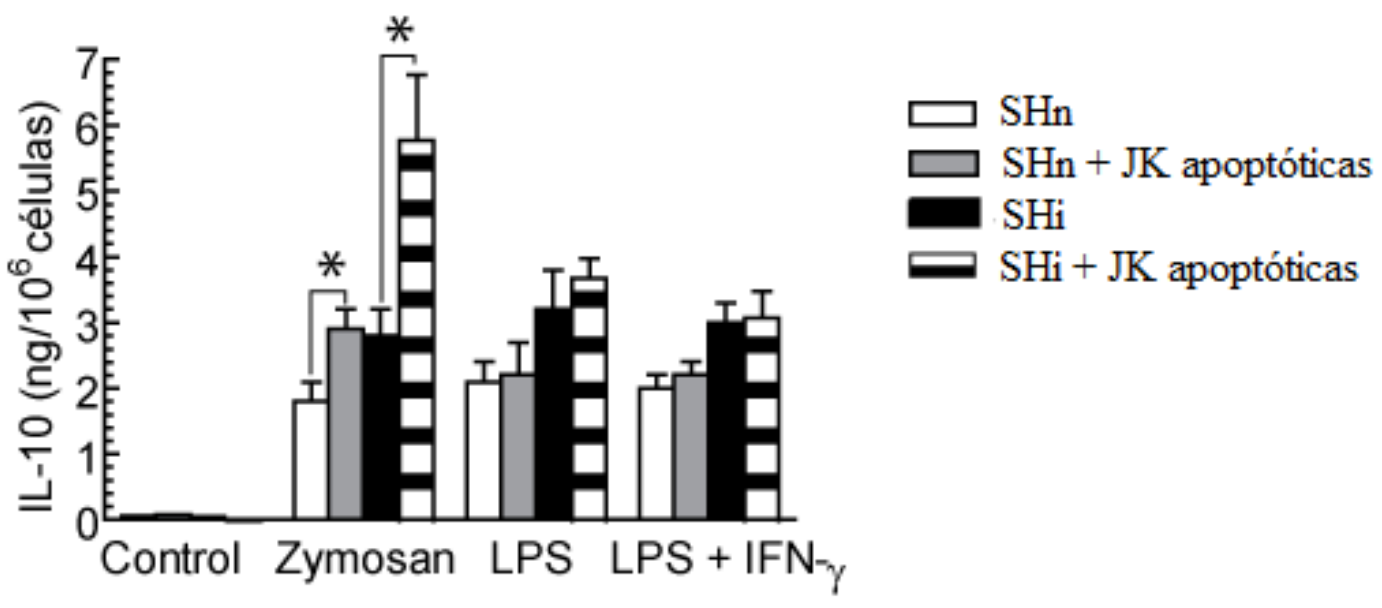

Figura 25: Producción de IL-10 por CD incubadas con células Jurkat apoptóticas en presencia de 10\% de SHn ○ SHi. Las CA se añadieron una hora antes de los estímulos. Los datos representan media \pm DE de 4 experimentos independientes. *Indica un valor de $p<0.05$.

\section{Regulación transcripcional de il10 durante el reconocimiento de las células apoptóticas}

La regulación de la transcripción de il10 depende principalmente del factor de trascripción CREB. Un estudio previo demostró que la regulación de la transcripción de il10 en respuesta al zymosan depende de la formación de un complejo en el promotor que incluye el factor de transcripción CREB y sus coactivadores CBP y CRTC/TORC2, junto con otros componentes de la maquinaria de transcripción (Alvarez et al., 2009). Con estos antecedentes y puesto que la actividad de CREB puede modularse farmacológicamente, se analizó el efecto de diferentes tratamientos que actúan a través de la vía de receptores de prostanoides de la serie $\mathrm{E}$ (EP)/PKA/CREB. Los experimentos incluyeron el estudio del efecto de PGE 2 exógena, del inhibidor de la PKA H89 y de la ciclosporina A, que inhibe la fosfatasa calcineurina (Figura 26). 


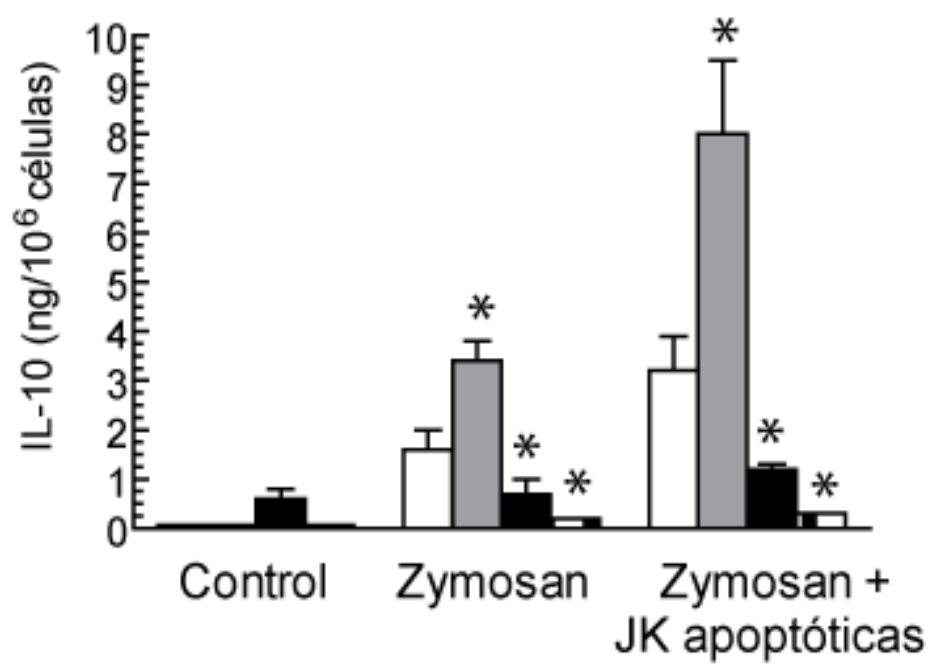

Figura 26: Efecto de la modulación farmacológica del sistema EP/PKA/CREB sobre la producción de IL-10. Las CD se incubaron durante 30 minutos con los diferentes fármacos a las concentraciones indicadas, posteriormente se estimularon con CA durante 1 hora y con zymosan durante 24 horas. Los datos representan media \pm DE de 4 experimentos independientes. *Indica un valor de $p<0.05$.

Los receptores del tipo EP2 se han implicado en la mediación del efecto anti-inflamatorio de las CA a través de la vía de señalización cicloxigenasa/PGE $/$ EP2/adenilato ciclasa/AMP cíclico (Medeiros et al., 2009). La adición de $\mathrm{PGE}_{2}$ mostró un efecto limitado en las células controles, sin embargo, en presencia de zymosan potenció la producción de IL-10 siendo este efecto más evidente en presencia de CA (Figura 26). El inhibidor de la PKA, H89, inhibió significativamente la producción inducida por el zymosan, tanto en presencia como en ausencia de CA. Este resultado justificaría la participación de PKA en la inducción de la producción de IL10 estimulada por las CA y estaría de acuerdo con el mecanismo general de regulación transcripcional de il10 por el sistema PKA/CREB (Alvarez et al., 2009).

La ciclosporina A disminuyó completamente la producción de IL-10 inducida por el zymosan, tanto en presencia como en ausencia de CA, lo que indicaría la participación de la calcineurina en la producción de esta citoquina (Figura 26). Este hecho podría explicarse mediante una acción mediada por CREB, puesto que CREB se regula también mediante fosforilaciones por quinasas dependientes de $\mathrm{Ca}^{2+} /$ calmodulina sensibles a la actividad fosfatasa de la calcineurina.

\subsection{Papel del co-activador CRTC2/TORC2}

En condiciones basales CRTC2/TORC2 está retenido en el citoplasma en un estado inactivo por interacciones dependientes de reacciones de fosforilación/defosforilación que 
determinan su asociación con la proteína 14-3-3. Cuando se incrementan los niveles intracelulares de $\mathrm{Ca}^{2+}$ y AMP cíclico, se activa la calcineurina y se produce la desfosforilación y translocación al núcleo de CRTC2/TORC2 donde lleva a cabo su función coactivadora de CREB.

En concordancia con este concepto, la pre-incubación de las CA con las CD indujo la traslocación transitoria de CRTC2/TORC2 al núcleo, lo que se observó entre 30-45 min tras la adición de las CA (Figura 27A y B), mientras que la incubación de las CA con zymosan no produjo la traslocación nuclear de CRTC2/TORC2 (Figura 27A panel inferior). El carácter transitorio de la traslocación de CRTC2/TORC2 puede explicarse por el complejo mecanismo molecular implicado en su activación/ desactivación, que incluye activación por desfosforilación, acetilación por CBP/p300, deacetilación por SIRT1 (sirtuin-1), ubiquitinación por la ligasa E3 nuclear y el marcaje para degradación en el proteasoma (Liu et al., 2008).

A

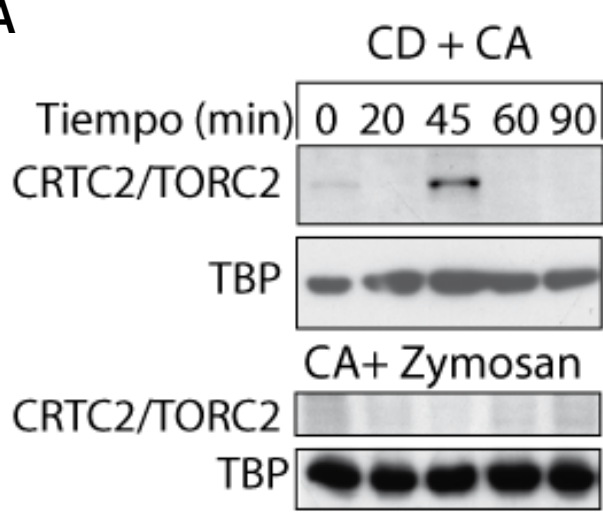

B

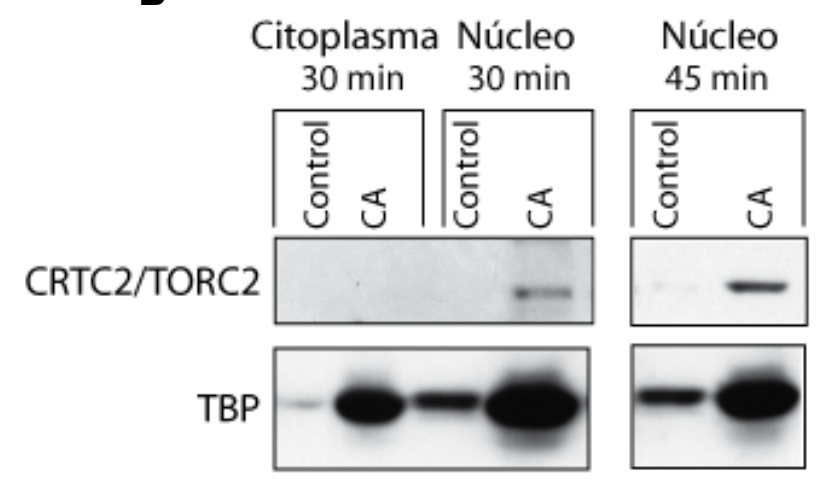

Figura 27: Translocación nuclear de CRTC2/TORC2 en CD incubadas con CA (A y B) y en CA incubadas con zymosan (A, panel inferior). La $\beta$-actina y el TBP se utilizaron como control de carga de las proteínas del citoplasma y del núcleo, respectivamente.

\subsection{Interacción entre CRTC2/TORC2 y la proteína PBX1}

CRTC2/TORC2 se ha descrito en complejos supramoleculares que contienen al factor de transcripción CREB y la homeoproteína PBX1 (Wang et al., 2010). Estudios previos han mostrado que PBX1 está implicada en la regulación de la producción de IL-10 por M $\varnothing$ en respuesta a CA (Chung et al, 2007). Sobre estas bases, se llevaron a cabo experimentos para demostrar la posible asociación de CRTC2/TORC2 con PBX1 en CD. De forma similar a lo observado con CRTC2/TORC2, las CA incrementaron la expresión y translocación de PBX1 a los 45 minutos, aunque en menor medida que el zymosan (Figura 28A). Además, la co- 
estimulación de zymosan con CA incrementó la translocación de CRTC2/TORC2 y PBX1 (Figura 28B).

A

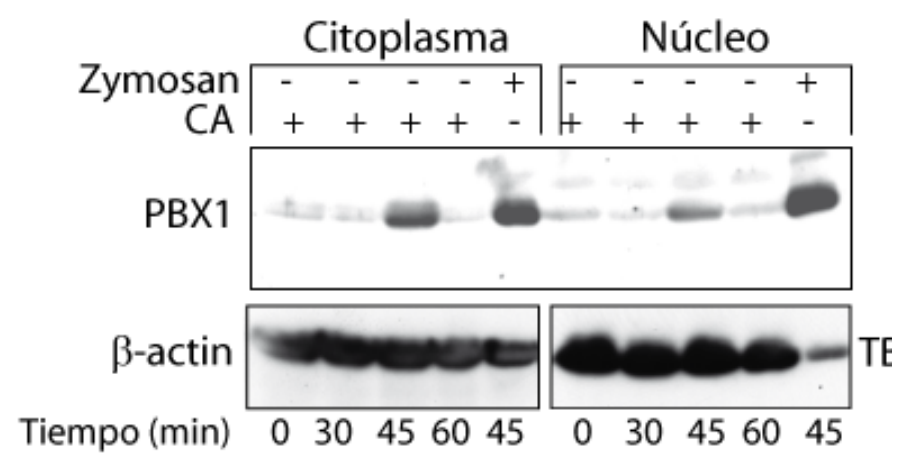

B

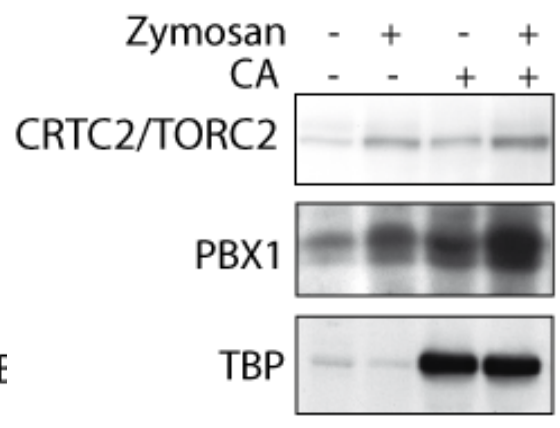

Figura 28: (A) Inducción y translocación nuclear de PBX1 en CD incubadas con CA y zymosan. Las células se incubaron con las CA y/o zymosan a los tiempos indicados para analizar la inducción de PBX1. (B) Inmunodetección de CRTC2/TORC2 y PBX1 en los extractos nucleares de CD estimuladas en presencia de zymosan y CA durante 45 minutos.

Estos resultados indicarían que la respuesta inducida por las CA aisladas no es suficiente para estimular la producción de IL-10 y que su efecto sólo se observa en presencia de un estímulo adicional como el zymosan.

Con respecto a los controles de carga se debe señalar que los carriles que llevaban las muestras con $C D$ y $C A$ muestran un ligero aumento en la carga de $\beta$-actina y un elevado aumento de la cantidad de la proteína nuclear TBP. Una posible explicación podría ser que las células Jurkat tienen un citoplasma pequeño, mientras que las DC tienen un citoplasma de gran tamaño asociado a la capacidad para la captación y procesamiento de un gran número de partículas. Por esa razón, las preparaciones de CA estarían enriquecidas en TBP y aportarían una menor cantidad de $\beta$-actina.

\subsection{CRTC2/TORC2 co-inmunoprecipita con PBX1}

El incremento de la expresión y translocación a los 45 minutos de ambas proteínas sugiere una posible cooperación para generar la respuesta final observada en las CD. Para analizar este aspecto, se llevaron a cabo experimentos de co-inmunoprecipitación entre PBX1 y CRTC2/TORC2, y de estas proteínas con P-CREB (Figura 29). Tanto la combinación de las CA con el zymosan, como los estímulos por separado muestran interacción de las proteínas CTRC2/TORC2 y PBX1 (Figura 29A). Asimismo, el estímulo exclusivo de las CA mostró la 
interacción de CRTC2/TORC2 y PBX1 con P-CREB (Figura 29B). Estos resultados son compatibles con el papel regulador de la transcripción de il10 por un complejo supramolecular que contiene P-CREB, los co-activadores CBP y CRTC2/TORC2, y PBX1.

A

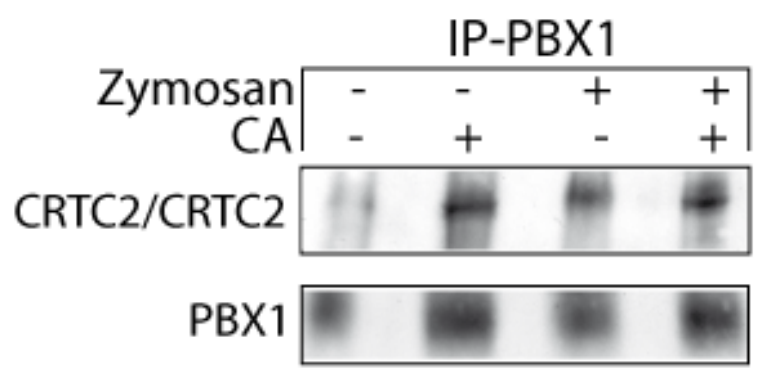

B

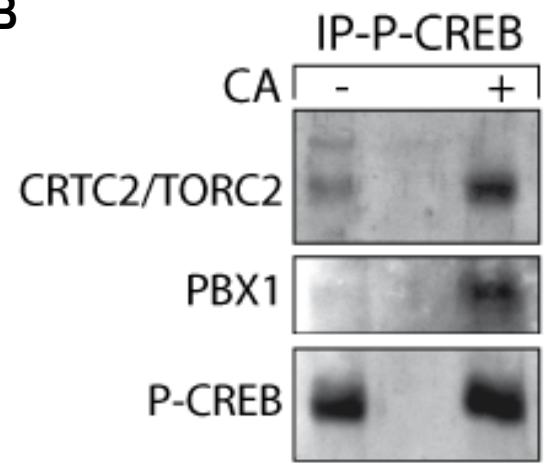

Figura 29: Interacción entre CRTC2/TORC2, PBX1 y CREB en CD. (A) Co-inmunoprecipitación de PBX-1 y CRTC2/TORC2 en la fracción nuclear de células estimuladas con zymosan y CA. (B) Co-inmunoprecipitación de PBX1 y CRTC2/TORC2 con P-CREB en células estimuladas con CA. La incubación con el estímulo fue en ambos casos de 45 minutos. Los lisados celulares de las CD se inmunoprecipitaron con anticuerpos frente a PBX1 y PCREB y para la inmunodetección se utilizaron anticuerpos frente a CRTC2, PBX1 y P-CREB.

\section{La posible participación de PPAR- $\gamma$}

La función del factor de transcripción PPAR- $\gamma$ en CD depende de la presencia de activadores exógenos o endógenos, alguno de los cuales se encuentran presentes en el SH. Con el fin de estudiar la posible participación del PPAR- $\gamma$, se realizó un estudio inicial de la translocación nuclear de este factor de transcripción en presencia de FBSi, SHn y SHi en CD tratadas con zymosan (Figura 30).

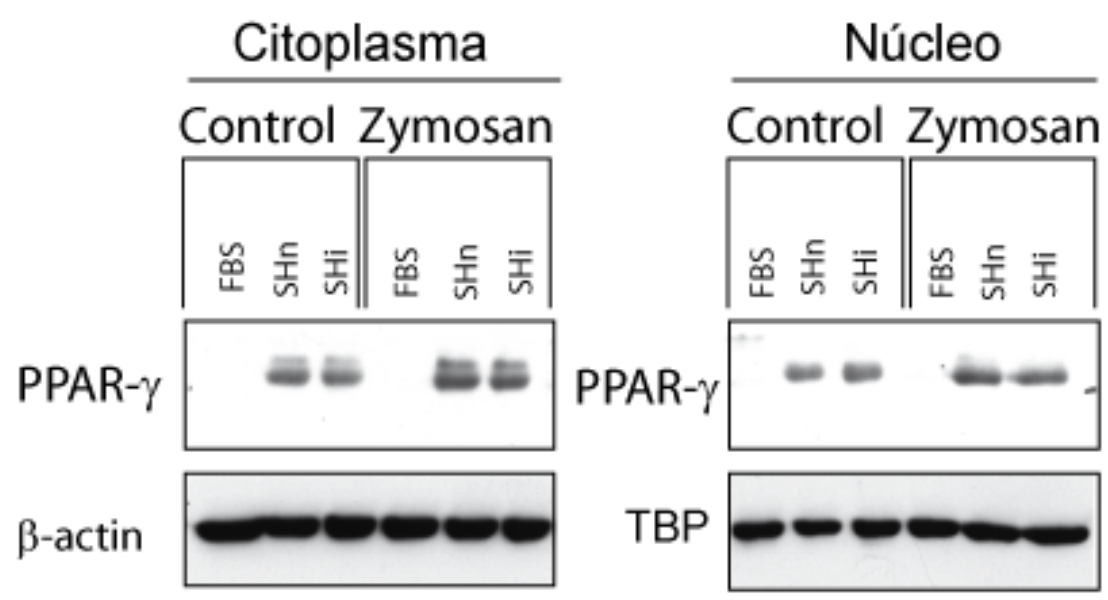

Figura 30: Efecto del SH y del FBSi en la activación y translocación al núcleo del PPAR- $\gamma$. Las CD se incubaron durante 1 hora en presencia de $10 \%$ de FBSI, SHn y SHi. 
La expresión y translocación del PPAR- $\gamma$ solo se observó cuando las CD se incubaron con SH independientemente de que éste hubiese sido inactivado por calor o no (Figura 30). En consecuencia los siguientes experimentos se realizaron en presencia de SHn. Este hecho indicaría el importante papel de los factores endogenos del suero en la activación del PPAR- $\gamma$.

\subsection{Papel del PPAR- $\gamma$}

Se estudió la translocación al núcleo y el efecto del bloqueo farmacológico de PPAR- $\gamma$ por el antagonista GW9662. Como se muestra en la Figura 31, el zymosan induce la translocación al núcleo del PPAR- $\gamma$ tras una y tres horas de incubación. El GW9662 disminuye la translocación al núcleo del PPAR- $\gamma$ inducida por el zymosan a las 3 horas, sin afectar la translocación a 1 hora.
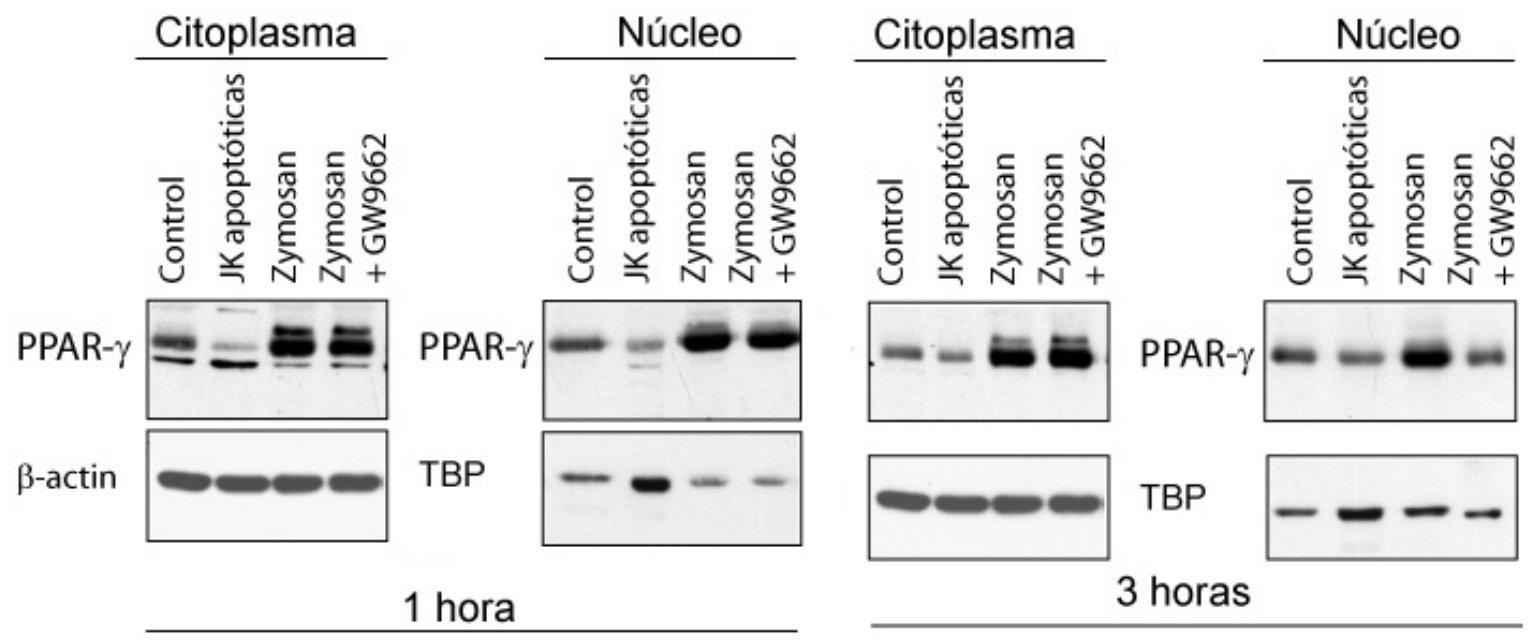

3 horas

Figura 31: Efecto del suero humano en la activación y translocación al núcleo del PPAR- $\gamma$ inducido por el zymosan y las CA. Las CD se incubaron durante 1 hora en presencia de 10\% SHn. La concentración del GW9662 fue de $5 \mu \mathrm{M}$ y el zymosan y las CA se utilizaron a las concentraciones habituales.

En la Figura 32 se observa que el GW9662 redujo la producción de IL-10 inducida por el zymosan, tanto en presencia como en ausencia de las CA. El mismo efecto se observó cuando se utilizó la combinación de LPS + IFN- $\gamma$. El zymosan opsonizado indujo la mayor producción de IL-10, que también fue sensible a la inhibición por GW9662. En lo que se refiere a la producción de IL-12 p70, el GW9662 no produjo ningún efecto en respuesta al zymosan (datos no 
mostrados). El conjunto de resultados sugiere que el PPAR- $\gamma$ se activa en nuestro sistema por un mecanismo dependiente de receptores del complemento, como CR3, y de receptores de $\beta$ glucanos, como dectin-1.

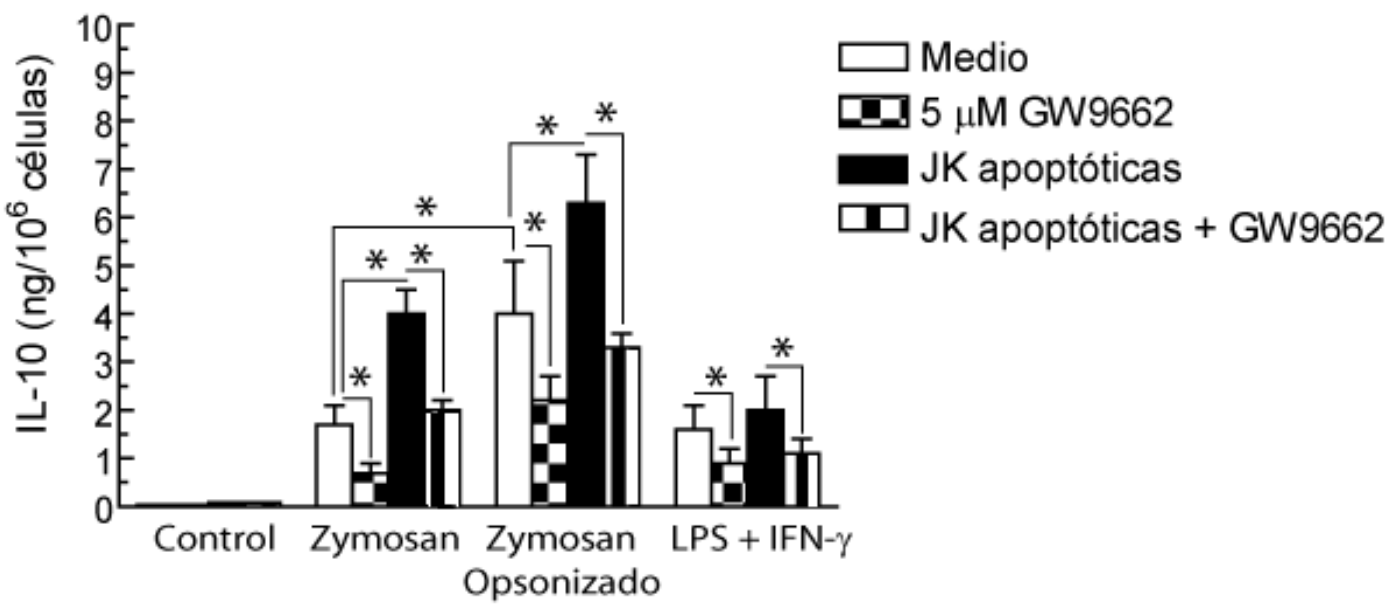

Figura 32: Efecto del GW9662 sobre la producción de IL-10 en CD pre-tratadas o no con CA en presencia de $10 \%$ de SHn. El GW9662 se añadió 1 hora antes que los estímulos. Los datos representan media \pm DE de 4 experimentos independientes por duplicado. *Indica un valor de $p<0.05$ para la comparación entre la preincubación $C D$ con CA tratados en presencia y ausencia de GW9662 y entre las CD tratadas con zymosan y zymosan opsonizado en ausencia de otros estímulos.

\section{Formación de cuerpos lipídicos como posibles efectores de la tolerancia inmune inducida durante el reconocimiento de células apoptóticas}

Algunos estudios describen que durante la respuesta a la infección, las células fagocíticas tienen la capacidad de acumular lípidos en orgánulos citoplasmáticos denominados cuerpos lipídicos, los cuales se han implicado en los cambios metabólicos asociados al proceso inflamatorio (Almeida et al., 2009). La formación de estos cuerpos lipídicos depende de la activación de TLRs (Pacheco et al., 2002) y PPAR- $\gamma$ (De Assis et al., 2003). Por otra parte, se han implicado en la síntesis de eicosanoides por la presencia en ellos de enzimas como COX-2 (Pacheco et al., 2002) y se ha descrito su capacidad de modular la respuesta inmune frente a microorganismos como Mycobacterium bovis (Almeida et al., 2009).

La posible presencia de los cuerpos lipídicos en $C D$ se analizó mediante fluorescencia por citometría de flujo con el fluoróforo Bodipy ${ }^{\circledR}$. El análisis no reveló modificación de la MFI en las CD marcadas con Bodipy ${ }^{\circledR}$ en presencia o ausencia de CA (Figura 33). Este hallazgo indicaría que las CA no inducen un aumento de la formación de cuerpos lipídicos en CD. En presencia de zymosan observamos un aumento de la MFI (Figura 33), pero este resultado podría 
ser un falso positivo, puesto que al analizar la fluorescencia emitida por el zymosan, se observó que éste puede marcarse por el Bodipy® (datos no mostrados).

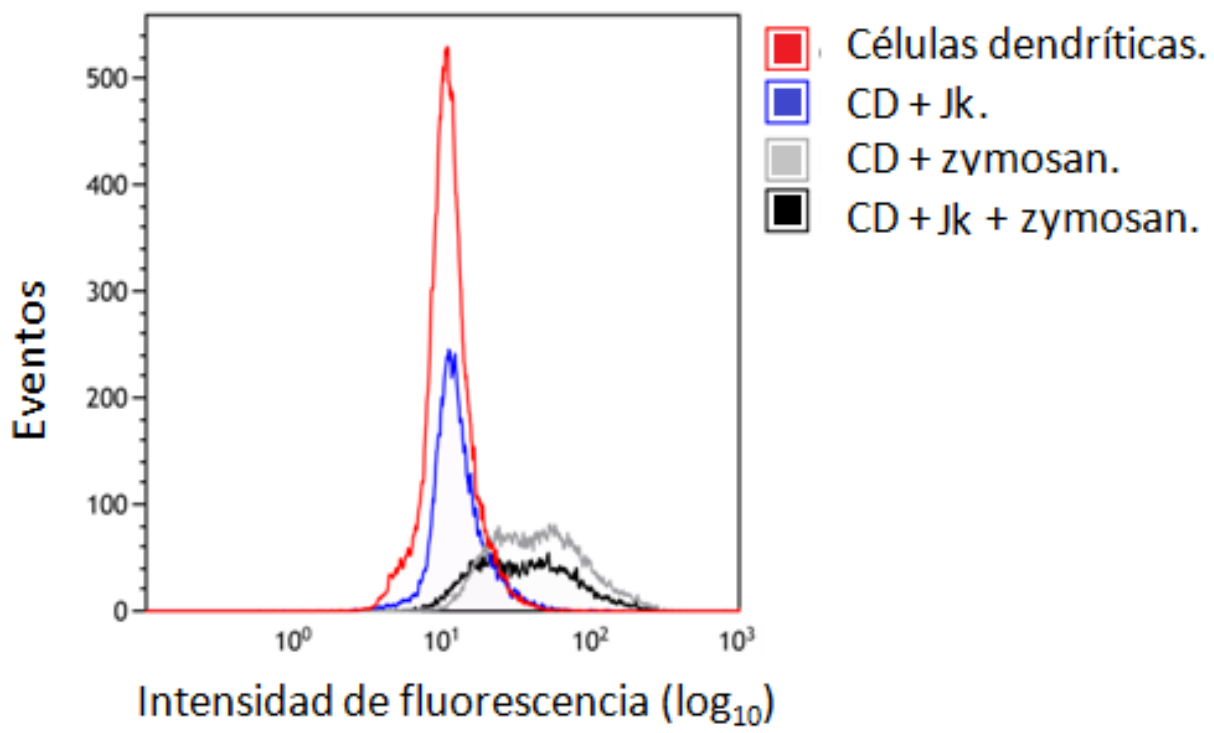

Figura 33: Análisis por citometría de flujo de la formación de cuerpos lipídicos en CD mediante marcaje con el Bodipy®. La población de CD se seleccionó por la expresión de CD206. La intensidad de fluorescencia del Bodipy $\circledast$ se midió en FL1. La longitud de onda de excitación es de $493 \mathrm{~nm}$ y la de emisión de $503 \mathrm{~nm}$. Los datos se procesaron mediante el software Kaluza ${ }^{T M}$. La estimulación de las $C D$ con distintos estímulos se realizó durante 16 horas.

Con la finalidad de obtener datos adicionales que justifiquen esta interpretación, se analizó la formación de cuerpos lipídicos en presencia del antagonista de PPAR- $\gamma$. Los resultados obtenidos indicaron que el GW9662 no tiene ningún efecto sobre la fluorescencia inducida por el Bodipy®, obteniendose la misma MFI en presencia y ausencia de GW9662 en las CD tratadas con zymosan y con CA (Figura 34). En conclusión, nuestros resultados no indican de forma concluyente que la fagocitosis de zymosan o de CA induzca la formación de cuerpos lipídicos y sugieren que el zymosan puede producir interferencia por la interacción con el Bodipy ${ }^{\circledR}$. 


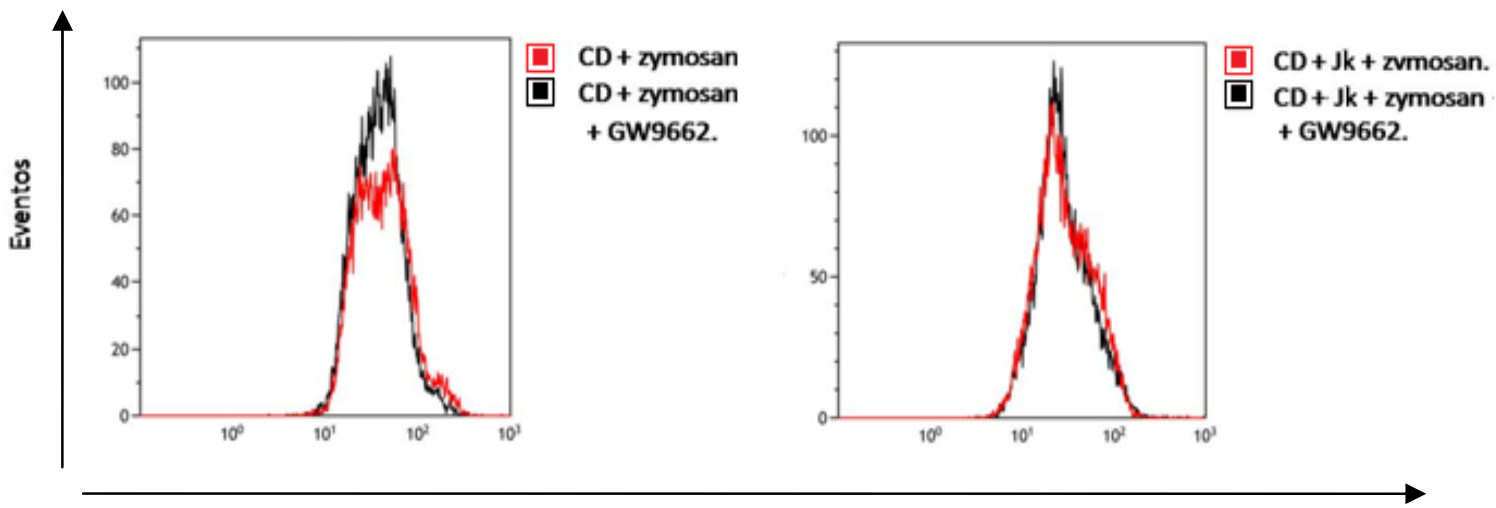

Intensidad de fluorescencia $\left(\log _{10}\right)$

Figura 34: Análisis por citometría de flujo de la formación de cuerpos lipídicos en CD. La población de CD se seleccionó por la expresión de CD206. La incubación con los estímulos se realizó durante16 horas. La concentración de GW9662 fue de $10 \mu \mathrm{M}$ y se añadió 30 minutos antes que los estímulos.

\section{Metabolismo del ácido araquidónico en células dendríticas en respuesta a las células apoptóticas}

Puesto que se ha implicado la secreción de mediadores lipídicos como un mecanismo operativo en la potenciación de la respuesta anti-inflamatoria inducida por la fagocitosis de las $\mathrm{CA}$, nos planteamos analizar el efecto de las $\mathrm{CA}$ sobre la liberación de ácido araquidónico (AA) y la producción de $\mathrm{PGE}_{2}$, que en estudios previos se ha demostrado que es el eicosanoide producido en mayor cantidad por las $\mathrm{CD}$ humanas y tiene un papel autocrino en la liberación de IL-10 inducida por zymosan (Alvarez et al., 2009).

En primer lugar, se analizó la liberación al medio de cultivo del [ $\left.{ }^{3} \mathrm{H}\right] \mathrm{AA}$ en respuesta a estímulos como el zymosan y los inmunocomplejos (IC), con el fin de poder comparar los resultados obtenidos con el efecto de estímulos fisiológicos. A diferencia de esos estímulos, las $\mathrm{CA}$ no indujeron liberación de [ $\left.{ }^{3} \mathrm{H}\right] \mathrm{AA}$ por las $\mathrm{CD}$, como se muestra en la Figura 35 . 


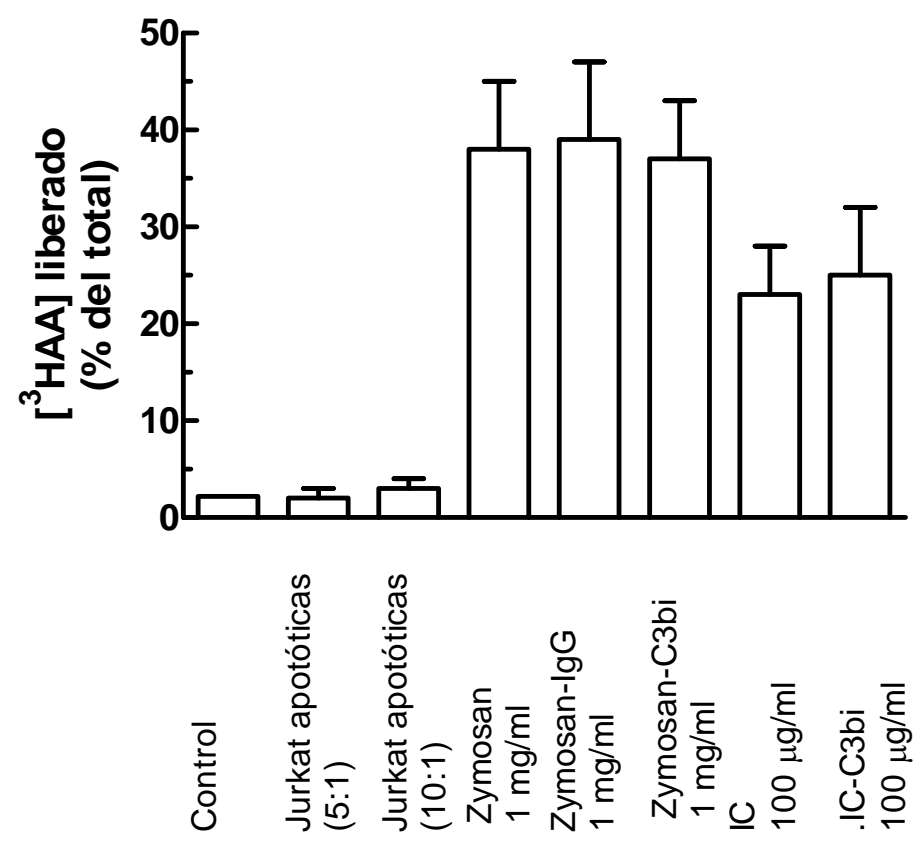

Figura 35: Liberación de AA por CD tratadas con distintos estímulos. Las células se marcaron durante cinco horas con $0.2 \mu \mathrm{Ci}$ de [ $\left.{ }^{3} \mathrm{H}\right] \mathrm{AA}$. Transcurrido ese tiempo, se lavaron con medio suplementado con BSA para eliminar la fracción no incorporada en los fosfolípidos de membrana y el medio se sustituyó por otro que contenía albúmina deslipidada. Tras la adición de los estímulos descritos durante una hora, la cuantificación del [3H]AA se analizó en sobrenadantes y en los precipitados celulares. Los datos representan media \pm DE de 4 experimentos independientes.

A la vista de que las CA no inducen liberación inmediata de $A A$, en comparación con los otros estímulos. Nos preguntamos si la posible producción de $\mathrm{PGE}_{2}$ pudiera explicarse a través de la inducción de la proteína COX-2 y de la acumulación de $\mathrm{PGE}_{2}$ como consecuencia del recambio basal del AA, más que por la producción del prostanoide mediada por la COX-1.

La Figura 36A muestra que aunque las CA indujeron ligeramente la expresión de COX-2, no aumentaron el efecto del zymosan y del LPS. En paralelo a las CA, también se estudió el efecto de las células Jurkat vivas y necróticas. Cuando se compararon las tres condiciones se observó que curiosamente las CA tienden a disminuir la expresión de COX-2 inducida por los estímulos pro-inflamatorios. La preincubación con CA durante 8 horas mostró resultados similares a los observados con la preincubación de 1 hora (Figura 36B). Asimismo, cuando se analizó la expresión de esta enzima en M $\varnothing$ las CA tendieron a disminuir la expresión de COX-2, incluso con el estímulo más activo para la inducción de COX-2 en M $\varnothing$ como es el manan (Figura $37 \mathrm{~A})$. 
A

1 HORA PREINCUBACIÓN,
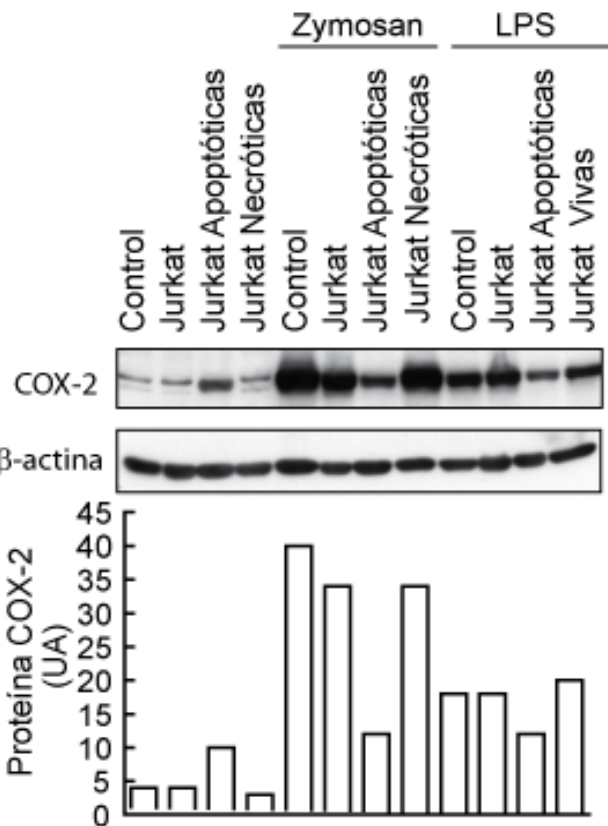

B

8 HORAS PREINCUBACIÓN

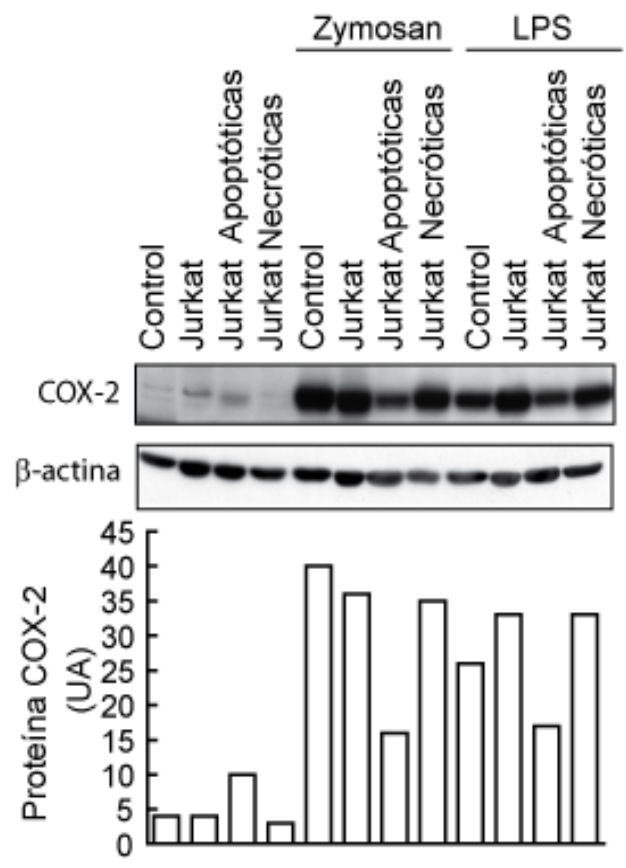

Figura 36: Efecto de la preincubación de CD con células Jurkat apoptóticas sobre la expresión de COX-2 durante 1 hora $(A)$ y 8 horas $(B)$ previamente a la adición de los otros estímulos. Los estímulos se añadieron a las concentraciones habituales. Al finalizar el periodo de incubación se obtuvieron los lisados celulares y se utilizaron para la inmunodetección de COX-2. La cuantificación de los blots se realizó por scanning densitométrico y se expresa en unidades arbitrarias (UA).

Para descartar que el efecto de las CA no se limite a las células Jurkat, se realizaron experimentos con PMN. Como muestra la Figura 37B la adición de PMN apoptóticos también produjo una disminución de la expresión de COX-2 en presencia de zymosan mientras que ese efecto no se observó con PMN recién aislados. 
A

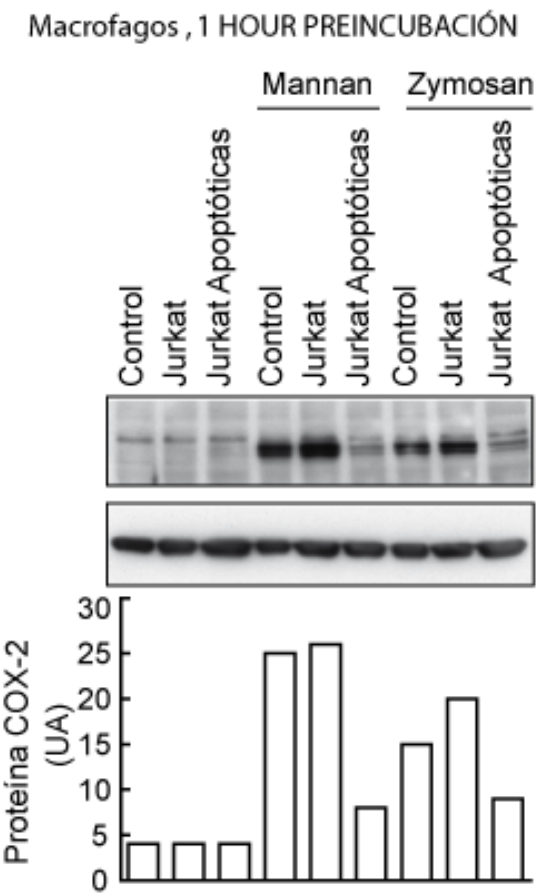

B
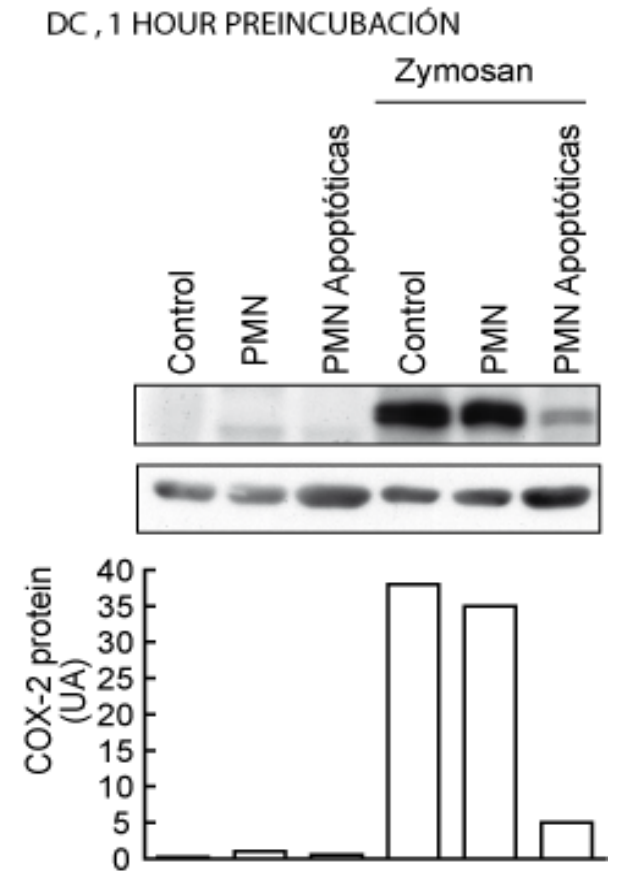

Figura 37: A) Efecto de la preincubación de $M \varnothing$ con células Jurkat apoptóticas sobre la expresión de COX-2. B) Efecto de los PMN apoptóticos sobre la expresión de COX-2 en CD. Los M $\varnothing$ se pre-incubaron en presencia de células Jurkat vivas y apoptóticas en la concentración habitual. La concentración de manan utilizada fue de 1 $\mathrm{mg} / \mathrm{ml}$. Las CD se pre-incubaron con los PMN de manera similar que con las células Jurkat. Tras 12 horas de incubación con los estímulos se obtuvieron los lisados celulares y se utilizaron para la inmunodetección de COX-2.

Además de disminuir la expresión de COX-2 producida por otros estímulos, las CA tampoco aumentaron la producción de $\mathrm{PGE}_{2}$, al contrario, disminuyeron la producción inducida por el zymosan (Figura 38). Este resultado indicaría que la $\mathrm{PGE}_{2}$ no interviene en la producción del efecto anti-inflamatorio de las CA. A la vista de la escasa relevancia de las liberaciones de PGE2 y TGF- $\beta 1$ observadas en nuestro sistema, el efecto inmunomodulador de estas moléculas no puede explicarse a través de su liberación por las CD como previamente se ha descrito en M $\varnothing$ (Fadok et al. 1998; Freire-de-Lima et al, 2006). 


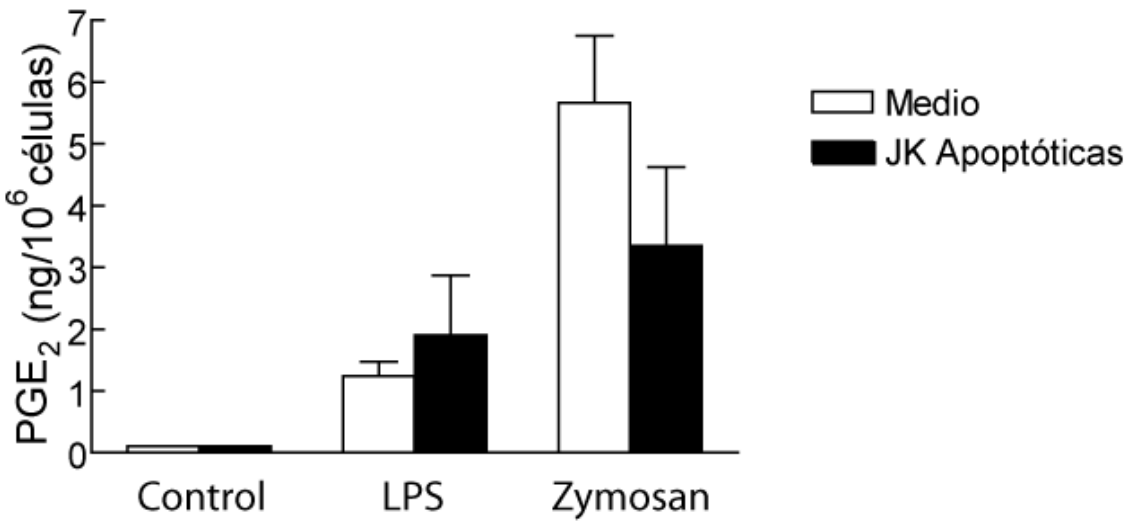

Figura 38: Producción de $\mathrm{PGE}_{2}$ en sobrenadantes de $\mathrm{CD}$ tratadas con los diferentes estímulos durante 24 horas. La preincubación de las $C D$ con las células Jurkat fue de 1 hora. Los resultados representan media $\pm D E$ de 6 experimentos.

\section{Liberación de esfingosina-1-fosfato por células apoptóticas}

Gude y col. (2008) sugirieron que la S1P secretada por las CA atrae a las células fagocíticas y favorece su fagocitosis. Teniendo en cuenta este antecedente, procedimos a cuantificar la S1P liberada por las CA mediante la técnica de cromatografía líquida acoplada a espectrometría de masas. De modo comparativo se utilizaron células Jurkat tratadas con camptotecina (JKc) y estaurosporina (JKs) y se cuantificó la S1P liberada en los sobrenadantes. La Figura 39 muestra que la acumulación máxima de S1P ocurre después de dos horas del tratamiento con agentes inductores de apoptosis, siendo la liberación de las JKs mayor que en las JKc.

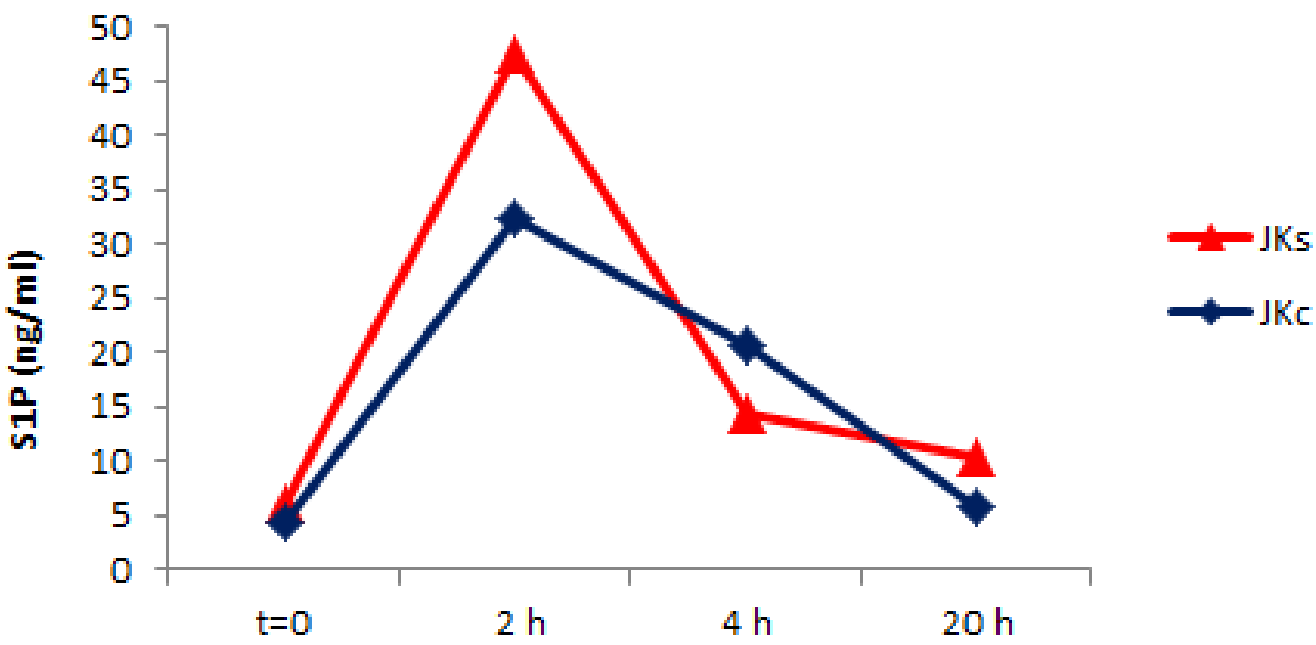

Figura 39: Cuantificación de S1P liberada en sobrenadantes de células Jurkat apoptóticas. Las células Jurkat a la concentración de $5 \times 10^{6} \mathrm{cél} / \mathrm{ml}$ se cultivaron en medio sin suero durante 4 horas con $10 \mu \mathrm{M}$ camptotecina o 3 horas con $5 \mu \mathrm{g} / \mathrm{ml}$ de estaurosporina. Tras la incubación se recogió el sobrenadante y las células se resuspendieron en medio sin suero para analizar el sobrenadante a los tiempos indicados. 
El espectro de fragmentación de los sobrenadantes de las CA tratadas con estaurosporina correspondiente a las 2 horas se muestra en la Figura 40, donde se observa un pico de $264.269 \mathrm{~m} / \mathrm{z}$ que corresponde al fragmento característico de S1P sin la molécula de agua. En la Figura 41 se representan los cromatogramas de ión extraído e iones totales. El fragmento característico de S1P se observa como un pico de alta intensidad con un tiempo de retención de 4.19 minutos. A los 6.43 minutos se obtuvo otro pico de alta intensidad que corresponde a la esfingomielina (SM), precursor de la ceramida (Figura 41A). El cromatograma de los iones totales se muestra en la figura 41B.

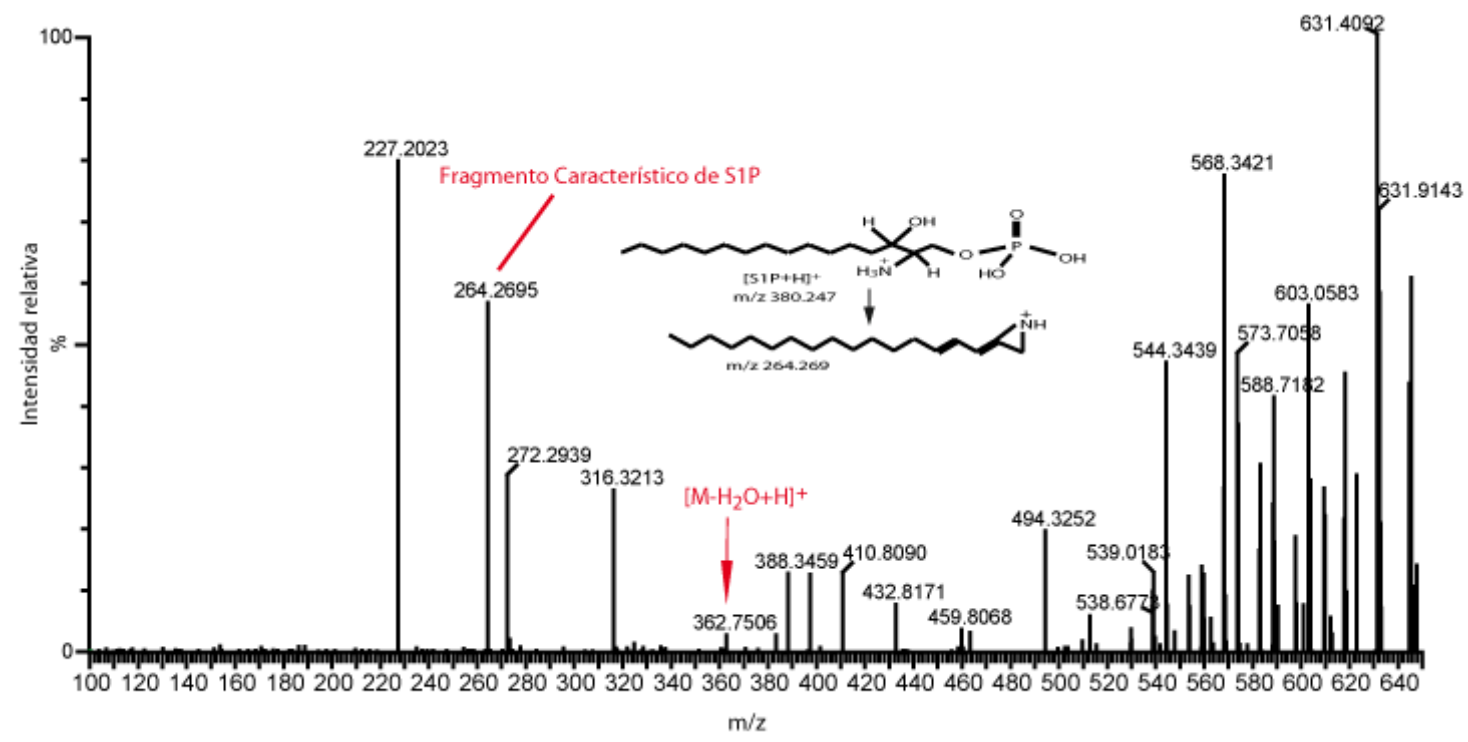

Figura 40: Espectro de fragmentación obtenido del pico cromatográfico de S1P de la función de baja energía. Se utilizó el sobrenadante obtenido tras 2 horas de incubación con estaurosporina y se indica el fragmento característico de S1P $(264.269 \mathrm{~m} / \mathrm{z})$ resultante de la fragmentación. 

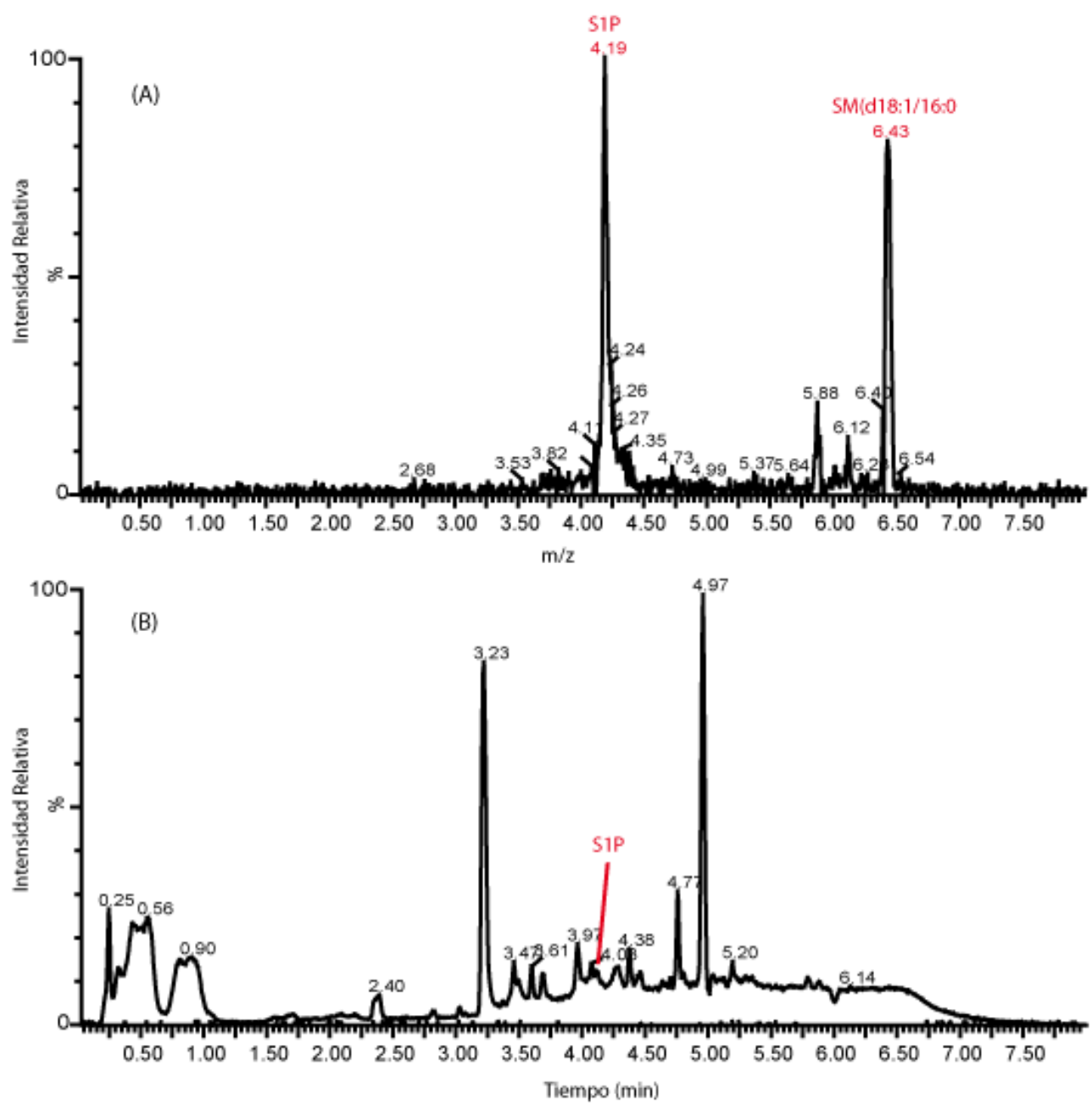

Figura 41: Cromatogramas de S1P obtenidos por espectrometría de masas de los sobrenadantes de JK tratadas durante 2 horas con estaurosporina. (A) Cromatograma de ión extraído del fragmento característico en función obtenida a alta energía por el método MSE (la intensidad máxima absoluta es $3.97 \times 10^{3}$ ). (B) Cromatograma de iones totales (TIC) en función de baja energía por el método MSE (la intensidad máxima absoluta es $2.72 \times 10^{3}$ ).

\subsection{Efecto de S1P en la producción de IL-10}

Una vez confirmada la liberación de S1P por las CA, estudiamos su posible efecto sobre la producción de IL-10. Los experimentos iniciales se centraron en analizar los cambios en la transcripción del ARNm que codifica il10 por RT-PCR a tiempo real en las dos poblaciones de $M \varnothing$ descritas (Tabla 2). La razón por la que se utilizó $M \varnothing$ se explica por dos razones, por un lado, los estudios dirigidos a la liberación S1P por CA se han realizado en estas células (Gude et al., 2008). Por otra parte, debido a la adherencia al plástico de los $M \varnothing$, el empleo de estas células permite un sistema más apropiado para la purificación de ARNm, puesto que las CA no fagocitadas pueden eliminarse con el medio, a diferencia del sistema de CD, donde estas células 
se mantienen en suspensión con las CA y no es posible la separación correcta de ambas poblaciones.

La Figura 42 muestra el efecto de la S1P sobre la expresión de il10 en M $\varnothing S H$. En los $\mathrm{M} \varnothing$ controles la S1P no produjo cambios significativos, mientras que aumentó ligeramente el efecto del zymosan. Curiosamente, la adición de S1P mostró un efecto sinérgico sobre la inducción del ARNm de il10 producida por las CA, que fue más marcado en el caso de las células JKc que cuando se emplearon células JKs. Un efecto similar se observó cuando se estudiaron M $\varnothing \mathrm{M}-\mathrm{CSF}$ estimulados con JKc en combinación con zymosan (Figura 43).

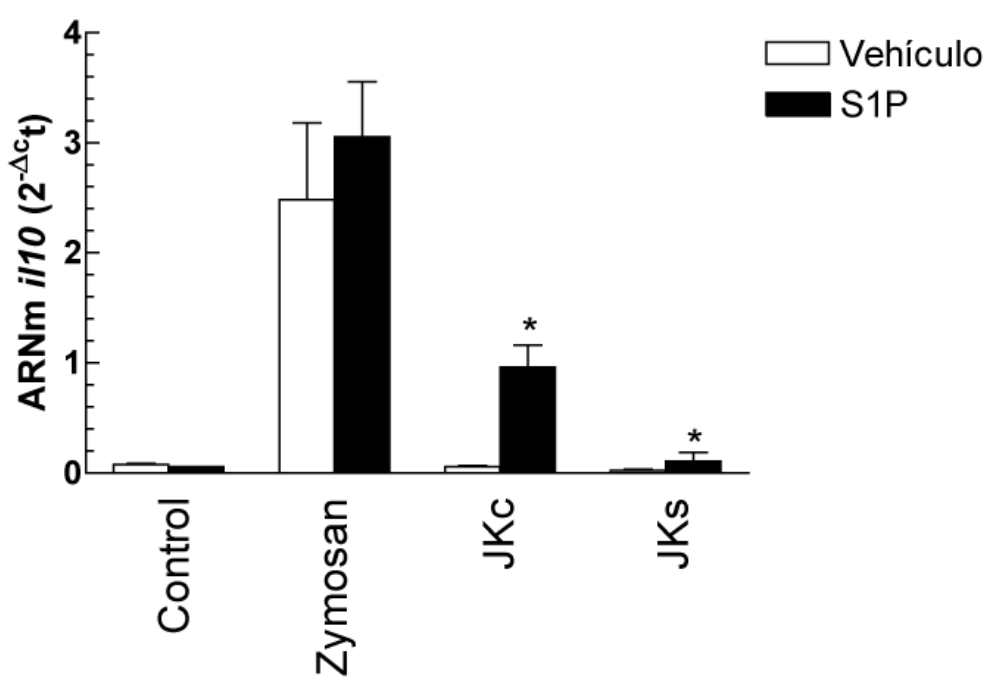

Figura 42: Niveles de expresión del ARNm de il10 en M $\varnothing$ diferenciados con $5 \%$ de SHi durante 7 días. La concentración de S1P fue $1 \mu \mathrm{M}$ y se añadió conjuntamente con cada estímulo durante 4 horas. Los resultados se normalizaron teniendo en cuenta la expresión de gadph. Se representan la media $\pm D E$ de 6 experimentos independientes. *Indica $p<0.05$.

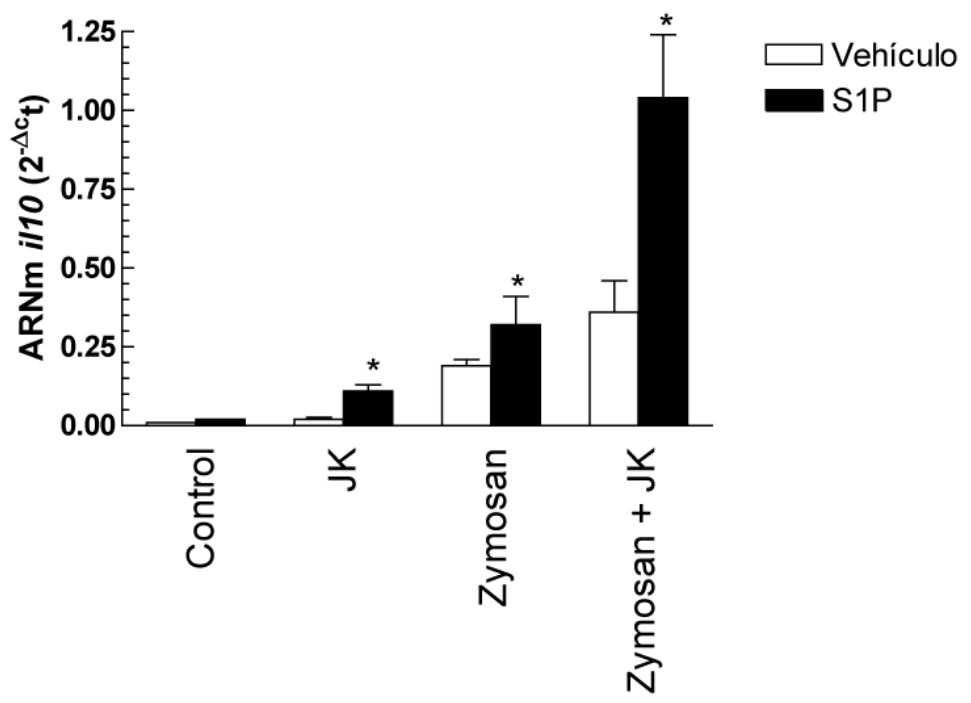

Figura 43: Efecto de la S1P sobre la expresión del ARNm de il10 en MØM-CSF. Los macrófagos se estimularon con células Jurkat tratadas con camptotecina y zymosan en presencia y ausencia de S1P. Los resultados se normalizaron de acuerdo con la expresión de gadph. *Indica $p<0.05$. 
Estos resultados indicarían que la S1P puede contribuir a aumentar el efecto de las CA sobre la indución de IL-10 por zymosan. Dada la relevancia de la $\mathrm{PGE}_{2}$ en la producción de IL-10 (Alvarez et al., 2009) y que se ha descrito que la S1P liberada por las CA puede incrementar la expresión de COX-2 (Chalfant et al., 2005), estos resultados podrían sugerir que el papel de la S1P se produjera a través de la expresión de COX-2. Con el fin de analizar este posible mecanismo, se estudió la expresión de los diferentes subtipos de receptores mediante la técnica de PCR semicuantitativa con cebadores específicos (Tabla 3). En la Figura 44 se observa la expresión de los receptores en M $\varnothing \mathrm{SH}$ que muestran niveles de expresión similares de s1p2 y s1p3, una expresión más reducida de s1p1 y ausencia de expresión de s1p4 y s1p5.

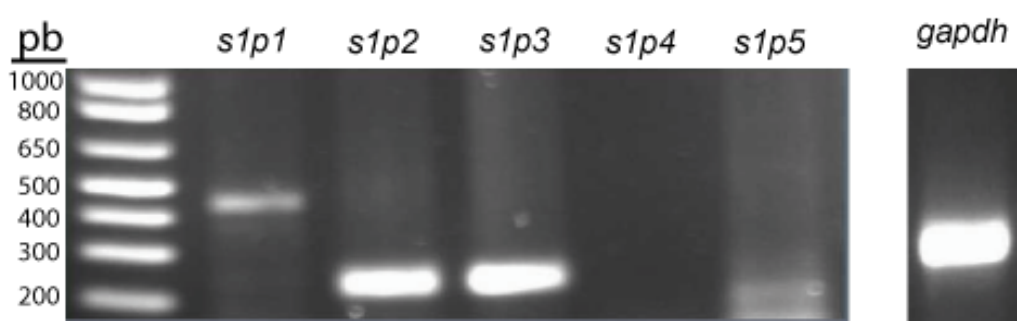

Figura 44: Expresión del ARN mensajero de los receptores de S1P. MØSH diferenciados durante 7 días.

Puesto que se ha referido que la expresión de los receptores $\mathrm{S}_{1} \mathrm{P}_{1}$ y $\mathrm{S}_{1} \mathrm{P}_{3}$ regulan positivamente la expresión de COX-2 (Brecht et al., 2011), estos resultados sugerirían que S1P pueda participar en la expresión de COX-2. Sin embargo, la S1P no modifica el efecto de las CA sobre la expresión de COX-2. Un resultado similar se observó en respuesta a altas dosis de LPS y, curiosamente, cuando la S1P se utilizó en presencia de CA y zymosan, no se observó inducción de COX-2 (datos no mostrados).

Estos datos indicarían que aunque la S1P muestra un efecto modulador de la producción de IL-10 inducida por las CA, éste no puede explicarse a través de la inducción de COX-2 y de un efecto autocrino a través del sistema $\mathrm{PGE}_{2} / E P / P K A / C R E B$. Por otra parte, el hecho de que existan cambios significativos en el nivel de expresión de il10 en presencia de S1P, y que estos dependan del agente inductor de apoptosis, sugeriría que la liberación de S1P por las CA podría tener un efecto similar al que produce la S1P exógena. Sin embargo, la liberación de S1P por las CA alcanza niveles muy reducidos en comparación con la concentración a la que la S1P exógena produce su efecto (Figura 39), por lo que puede inferirse que las CA no liberan cantidades de S1P suficientes para reproducir el efecto de la S1P exógena. 

Discusión 
Las $C D$ y los $M \varnothing$ actúan como centinelas encargados de la detección de daño tisular e infección, y pueden fagocitar CA. La mayoría de los estudios dedicados a analizar este proceso se han realizado en $M \varnothing$, posiblemente, por que éstos endocitan las $C A$ más eficientemente que las $C D$. Sin embargo, un factor que hace particularmente relevantes a las $C D$, es que éstas están más capacitadas para la captación y presentación de antígenos, lo que las confiere un protagonismo especial en la mediación entre la respuesta inmune innata y la adaptativa. Un estudio pionero realizado por Albert y col. (1998) demostró que las CD, además de fagocitar CA, pueden presentar los antígenos derivados de las células muertas, lo que puede conducir a la aparición de autoinmunidad y justifica la importancia de analizar el patrón de citocinas producidas en estas condiciones por su papel en la polarización de la respuesta inmune. En el presente estudio se ha mostrado la capacidad de las CA para modular la producción de IL-10 e IL-23 inducidas por el zymosan, un estímulo cuya composición es similar a la de la pared de los hongos, y cuya acción sobre la regulación transcripcional de il10 es dependiente de CREB.

\section{La expresión de los receptores de membrana de las células fagocitarias depende del proceso de diferenciación y de los componentes del medio}

Los fagocitos profesionales difieren en su capacidad para la eliminación de los agentes patógenos extraños dado que por su gran plasticidad funcional pueden mostrar variaciones fenotípicas dependientes del microambiente en el que se encuentren. En el caso particular de las CD, el GM-CSF y la IL-4 aumentan la expresión de DC-SIGN y dectin-1. En el caso de los M $\varnothing$ el hallazgo más destacado es que la presencia de M-CSF incrementa la expresión de las isoformas de dectin-1 A y $B$, lo que les hace particularmente eficientes para la defensa frente a la infección por hongos.

\section{Las células Jurkat como un modelo reproducible de células en apoptosis temprana}

Para analizar el efecto de las CA elegimos el modelo de células Jurkat dado su amplio empleo en estudios similares y la posibilidad de poder comparar los resultados con los referidos en la literatura. Nuestros estudios muestran que tras 4 horas de tratamiento con camptotecina, aproximadamente, el 60\% de CA están en una fase de apoptosis temprana, apropiada para la realización de los experimentos en condiciones reproducibles. Por el contrario, a las 24 horas el 
porcentaje de células en esta fase disminuye notablemente, mientras que aumenta el número de CA en fase tardía para alcanzar, aproximadamente, el 55\%, aunque se mantiene una proporción baja de células necróticas.

Los valores obtenidos son comparables a los publicados por otros autores utilizando el mismo procedimiento experimental y a los obtenidos con etoposido (inhibidor de la toposoimerasa II) y actinomicina D (inhibidor de la transcripción) (Kozmar et al., 2010). En contra del empleo de la actinomicina $D$ para inducir apoptosis estaría el hecho de que a la concentración utilizada interfiere con la función de las CD. El tratamiento con estaurosporina reveló una proporción de CA en fase temprana similar al obtenido tras tratamiento con camptotecina, sin embargo, el porcentaje que observamos fue más bajo $(\sim 50 \%)$ que el referido en los trabajos de Weigert y col. (2006) y Gude y col. (2008), donde la cantidad de CA se mantuvo alrededor del $80 \%$. Por otra parte, los PMN sometidos a apoptosis espontánea mostraron a las 24 horas un mayor número de células en apoptosis temprana y una mayor presencia de células en apoptosis tardía y necrosis en comparación con las células Jurkat.

\section{Efecto modulador de las células apoptóticas sobre la producción de citoquinas y mediadores inflamatorios inducida por zymosan y LPS}

Una consecuencia de las infecciones por hongos es la persistencia de un estado de inmunodepresión dependiente de la liberación de mediadores con actividad inhibitoria de la respuesta inflamatoria, que puede llegar a bloquear la erradicación del patógeno. Esta respuesta se explica por los cambios en el patrón de producción de citoquinas con elevados niveles de IL10 y baja secreción de IL-12 p70. De forma similar a lo descrito en referencia a las infecciones por hongos, trabajos previos describen que las CA modulan el equilibrio entre la producción de IL-10 e IL-12 p70, pudiendo suprimir la respuesta inmune a través de la liberación de citoquinas anti-inflamatorias e inhibición de las pro-inflamatorias (Savill et al., 2002; Ip et al., 2004; Kim et al., 2004; Zhang et al., 2010). En contradicción con estos estudios, los resultados aquí descritos sugieren que las CA no inducen la producción de IL-10, incluso en el rango más alto de las proporciones utilizadas de CA:CD (30:1). Sin embargo, cuando se estudia el efecto de las CA en combinación con zymosan, se observa que las CA modulan positivamente la producción de esta citoquina, al observarse un efecto sinergístico en relación con la liberación observada en ausencia de CA. En lo que se refiere a la IL-12 p70 las CA no inducen su producción ni modifican el efecto de los otros estímulos utilizados. Estos datos sugieren que la interacción de las CD con 
las CA modula selectivamente la respuesta del zymosan e induce una respuesta anti-inflamatoria que se caracteriza por una elevada producción de IL-10 y una escasa cantidad de IL-12 p70. En contra de nuestra predicción, las CA no mostraron capacidad para inhibir la respuesta proinflamatoria inducida por estímulos tan activos como la combinación LPS + IFN- $\gamma$.

El mecanismo de inhibición de IL-12 p70 por las CA se ha estudiado en M $\varnothing$ tratados con LPS. Este efecto es independiente de la producción de IL-10 y de TGF- $\beta$, y se explica mediante la inhibición de la transcripción de la subunidad IL-12 p35 (Kim et al., 2004). Por otra parte, el zymosan es un estímulo débil para la inducción transcripcional de IL-12 p35, pero induce una expresión detectable de IL-12 p40 que es utilizada casi exclusivamente para la producción de IL23 (Alvarez et al., 2011). El análisis de la producción de IL-23 en nuestro sistema reveló que las CA modulan negativamente la producción de IL-23, lo que se podría explicar por un efecto sobre la regulación transcripcional de il23a o de il12/23b.

En los últimos años, la caracterización de los mediadores químicos involucrados en el papel inmunomodulador de las CA se ha centrado en el estudio de las citoquinas IL-12 p70, IL10, e IL-23 y en la del factor TGF- $\beta 1$, especialmente porque estas moléculas contribuyen a la diferenciación de las células Th1, Treg, Th2 y Th17 (Torchinsky et al, 2009; Brereton et al., 2010). En nuestro sistema la producción de TGF- $\beta 1$ por parte de las CD fue escasa. Sin embargo, en los $M \varnothing$ diferenciados en presencia de suero humano, las $C A$ indujeron una producción significativa del TGF- $\beta 1$. Estos datos indicarían que la inducción de TGF- $\beta 1$ por las $C A$ es una respuesta restringida a los $M \varnothing$ y $C D$ plasmocitoides que no se produce en las $C D$ derivadas de monocitos (Bonnefoy, 2011).

Debe precisarse que las concentraciones y combinaciones de los estímulos se seleccionaron a partir de los resultados de estudios previos, en los que se observó que a concentraciones de hasta $20 \mu \mathrm{g} / \mathrm{ml}$ de LPS no se satura la producción de IL-12 p70 por las CD, posiblemente por la disminución de la expresión del coreceptor del LPS, CD14, que se produce durante la diferenciación de los monocitos a CD. En el caso del zymosan, la respuesta óptima se observa a partir de concentraciones superiores a $0.5 \mathrm{mg} / \mathrm{ml}$ y tiende a disminuir a partir de 2 $\mathrm{mg} / \mathrm{ml}$. (Alvarez et al., 2009 y 2011)

A la vista del posible paralelismo entre las rutas de señalización que se desencadenan durante el reconocimiento de CA y hongos, nuestros resultados están en línea con los trabajos que describen mecanismos comunes de captación y señalización para los PAMPs que se expresan en las superficies de las CA y hongos. Así, se ha referido que en el humano, las CA son reconocidas por dectin-1 en colaboración con TLR, por lo que estos receptores intervendrían 
en su captura y en el procesamiento y presentación de antígenos (Weck et al., 2008). Asimismo, Chung y col. (2007) destacaron la capacidad de CD36 para la captura de las CA y la producción de IL-10 por un mecanismo que implica la fosforilación de una tirosina de PREP-1 y la dimerización de las proteínas PBX1 y MEIS. También se ha referido que el ortólogo de CD36 y SCARF, CED-1 (ortólogo de Drape en Drosophila sp. [Chung et al., 2000]), es esencial para la captura de CA (Zhou et al., 2001) en Caernohabditis elegans y tiene la capacidad de unirse a Shark, una tirosina quinasa similar a SYK en Drosophila sp. (Ziegenfuss et al., 2008), a través de los motivos ITAM. De forma similar, los receptores de $\beta$-glucanos SCARF y CD36 participan en la defensa frente a la infección por hongos y CED-1 pueden contribuir a la fagocitosis de cuerpos celulares (Means et al., 2009). Tomados en conjunto, estos datos indican la similitud entre las señales de Drape/Src42A/Shark en C. elegans, y las de los CLR/Syk en el sistema inmune de mamíferos (Zhou et al., 2001). Asimismo, se ha descrito recientemente la participación de otro CLR, CLEC9A, en el reconocimiento de células en apoptosis tardía y necróticas mediante una interacción en la que juegan un papel central dos residuos de triptófano en el sitio de unión del ligando que están conservados en humanos y ratones (Zhang et al., 2012) y que permiten el desencadenamiento de una señal dependiente de SYK (Sancho et al., 2009).

Las opsoninas mejoran el reconocimiento de las CA al actuar como puente entre las CA y los receptores expresados en la membrana de los fagocitos. En este sentido, se ha descrito que la opsonización de CA por factores del complemento produce una respuesta antiinflamatoria caracterizada por un moderado incremento de la producción de IL-10 y una inhibición de la activación del sistema NF-кB (Amarilyo et al., 2010). En este estudio hemos encontrado que el efecto de las CA sobre la producción de IL-10 no es dependiente de la integridad del sistema del complemento, sino de otras moléculas presentes en el suero, a juzgar por la persistencia del efecto en suero inactivado por calor.

\section{Mecanismos de la regulación transcripcional de il10 implicados en el reconocimiento de células apoptóticas y hongos}

Dado que la expresión de citoquinas se regula, principalmente, a nivel transcripcional, la hipótesis más plausible es que el efecto de las CA también se produzca a este nivel. A la vista de los resultados obtenidos, el efecto potenciador de las CA sobre la producción de IL-10 puede explicarse a través de la transcripción dependiente del sitio CRE, en concordancia con el hecho de que CREB es el principal regulador de la transcripción de IL-10 (Alvarez et al., 2009). 
En las CD la respuesta al zymosan depende del balance entre NF- $\kappa B$ y la actividad de CREB, que a su vez se potencia por la $\mathrm{PGE}_{2}$ (Alvarez et al., 2009). En este sentido, se ha referido que las CA son capaces de inhibir la activación de NF-kB inducida por LPS y la consiguiente producción de proteínas con actividad pro-inflamatoria; sin embargo, no se ha confirmado la participación de NF-kB en el mecanismo de regulación ejercido por las CA (Cvetanovic y Usker, 2004, Cvetanovic et al., 2006). Tomados en conjunto, nuestros resultados concuerdan con la hipótesis de que la interferencia de las CA con el proceso de transcripción es independiente de la activación y movilización nuclear de NF-кB.

Estos antecedentes y los resultados obtenidos en nuestros experimentos sugirieren que las CA pueden ejercer su efecto actuando sobre la activación de CREB y el reclutamiento del coactivador CBP, que es utilizado por NF- $\kappa B$ y CREB. Por este motivo, el reparto de CBP es un factor limitante de la transactivación dependiente de estos factores de transcripción. El hecho de que el zymosan induzca el reclutamiento de CBP y la translocación de CRTC2/TORC2 al núcleo (Alvarez et al., 2009), junto a la descripción de la inhibición de la actividad de NF-אB por la activación del receptor tirosina quinasa Mer durante el reconocimiento del complejo GAS6/PS por las CD (Sen et al., 2006; Alciato et al., 2010), permiten postular una mayor disponibilidad para la asociación del complejo CBP/CREB/TORC2 al promotor de il10. En este sentido, hemos observado que tanto la adición CA como la coestimulación con zymosan inducen una translocación transitoria al núcleo de CRTC2/TORC2 y su asociación en el núcleo con P-CREB, habiendo descartado en experimentos controles, el efecto aditivo que pudieran aportar los factores aportados por las CA, puesto que cuando las CA se estimulan con zymosan no se observa translocación al núcleo de este factor de transcripción.

Estudios previos han mostrado la función del elemento regulador ACRE en el promotor de il10. ACRE une las proteínas PBX1 y PREP-1, junto con las proteínas con homeodominos HOX y MEIS1 tras la fagocitosis de CA, pero no en respuesta a otros estímulos como LPS (Chung et al., 2007). Asimismo, se ha descrito que este complejo también se asocia con el complejo de P-CREB/TORC2/CBP (Wang et al., 2010) y se conoce que la interacción entre MEIS1 y CRTC2/TORC2 depende de reacciones mediadas por PKA (Goh et al., 2009; Wang et al., 2010). Este mecanismo de control transcripcional, basado en la formación de un complejo con multiples sub-unidades, concuerda con la translocación de CRTC2/TORC2 y PBX1 y con la asociación de ambas proteínas con P-CREB. En este sentido, nuestros resultados apuntan a una convergencia entre las rutas de señalización desencadenadas por el reconocimiento de CA y $\beta$ - 
glucanos, ya que la participación de homeoproteínas en respuesta al reconocimiento de CA no se ha observado con otros estímulos (Chung et al., 2007).

Los estudios realizados con agentes farmacológicos concuerdan con el mecanismo de regulación transcripcional propuesto, a la vista de la participación de CREB en la inducción de IL10 producida por el zymosan (Alvarez et al., 2009), el efecto sinérgico producido por la $\mathrm{PGE}_{2}$ exógena y el efecto de los inhibidores de PKA. En este sentido, debe recordarse que el papel de la $\mathrm{PGE}_{2}$ depende de su papel estimulador sobre la producción de AMP cíclico. Asimismo, la disminución de la producción de IL-10 observada en presencia del inhibidor de PKA estaría de acuerdo con la regulación transcripcional mediada por CBP/CREB/TORC2 puesto que se demostrado que el inhibidor de la subunidad catalítica de PKA bloquea la unión de CREB al promotor de il10 y la producción de ésta citoquina (Alvarez et al., 2009). Dado que la regulación de la actividad de CREB también está mediada por quinasas dependientes de $\mathrm{Ca}^{2+} /$ calmodulina sensibles a la actividad fosfatasa de la calcineurina, y que esta fosfatasa interviene en la desfosforilación de CRTC2/TORC2 necesaria para su traslocación al núcleo, la disminución de la producción de IL-10 inducida por la ciclosporina A, puede interpretarse como un argumento adicional de la participación de CREB y CRTC2/TORC2 en la regulación transcripcional de il10 durante la fagocitosis de CA.

Otro factor de transcripción que se ha implicado en la regulación de IL-10 es PPAR- $\gamma$. Este hecho se ha demostrado por la rápida y transitoria activación del PPAR- $\gamma$ inducida por las

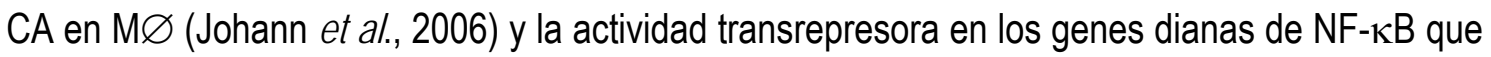
ocasiona la activación de PPAR- $\gamma$ (Bailey y Ghosh, 2005; Vargas et al., 2008). Nuestros resultados indicarían un papel del PPAR- $\gamma$ en la inhibición de la respuesta inflamatoria, a juzgar por la inducción de PPAR- $\gamma$ por el zymosan y la reducción de la producción de IL-10 observada en presencia de un inhibidor de PPAR- $\gamma$, especialmente cuando el medio contiene suero humano, pero estos datos no son suficientes para atribuir al PPAR- $\gamma$ un efecto directo en la regulación de la transcripción de il10 inducida por las CA. Puesto que el PPAR- $\gamma$ no tiene un papel directo en la transcripción de il10, el papel más probable de esta proteína podría ser indirecto y relacionarse con la inhibición de la actividad de NF- $\kappa$ B. Como se ha discutido en el caso de CREB, la inhibición de NF-kB por la actividad del PPAR- $\gamma$, permitiría una mayor eficiencia de la transcripción dependiente de CREB por el aumento de la disponibilidad de CBP para su interacción con CREB (Vo y Goodman, 2001). La participación de NF- $\kappa B$ en la regulación de IL-10 no se ha demostrado de forma concluyente, al menos en células humanas, e 
incluso la inhibición de NF-אB se asocia con el aumento de la producción de IL-10 (Alvarez et al., 2009; Kozmar et al., 2010).

EI PPAR- $\gamma$ juega un papel importante en el control de la inflamación, especialmente en lo que se refiere a la presencia de mediadores lipídicos. Los genes regulados por el PPAR- $\gamma$ implicados en el metabolismo lipídico están sobrerrepresentados entre los genes que muestran un mayor nivel de inducción y una fracción importante de éstos se relaciona con la respuesta inmune (Szatmari et al., 2007). La activación de PPAR- $\gamma$ se ha relacionado con metabolitos del AA. Por ejemplo, durante el reconocimiento de $M$. bovis por $\mathrm{M} \varnothing$ la síntesis de $\mathrm{PGE}_{2}$ se asocia a la formación de cuerpos lipídicos, es paralela a la expresión de PPAR- $\gamma$ y se inhibe por antagonistas del PPAR- $\gamma$ (Almeida et al., 2009). Asimismo, la formación de cuerpos lipídicos es un requisito para la producción de $\mathrm{PGE}_{2}$ en respuesta a ligandos de TLR en M $\varnothing$ (Pacheco et al., 2002). Dado que el zymosan es un ligando de TLR2 (Gantner et al., 2003; Brown et al., 2003; Dillon et al.; 2006) y puesto que se ha observado que los $\beta$-glucanos de la pared celular de Histoplasma capsulatum inducen la formación de los cuerpos lipídicos (Sorgi et al., 2009), nos planteamos la hipótesis de si el efecto de las CA y el zymosan en la producción de IL-10 podría estar relacionado con la formación de cuerpos lipídicos. A pesar de estos antecedentes, el análisis por citometría de flujo no reveló la formación de cuerpos lipídicos en CD tratadas con zymosan y CA. Una explicación de este hallazgo podría ser que la formación de los cuerpos lipídicos es específica de algunos tipos celulares y preferentemente observable en granulocitos y $M \varnothing$ (Bozza et al., 2009). Otra razón podría ser que la formación de los cuerpos lipídicos pudiera estar limitada a la respuesta a patógenos con una virulencia limitada como M. bovis. En este sentido, mientras que en el estudio de Almeida y col. (2009) se describe que la inhibición de PPAR- $\gamma$ tiene un efecto negativo sobre la formación de cuerpos lipídicos y la producción de $\mathrm{PGE}_{2}$; en CD se ha descrito que la activación de PPAR- $\gamma$ se asocia con una disminución de los cuerpos lipídicos (Szatmari et al., 2007) que se explicaría por el incremento del metabolismo lipidico y el efecto anti-inflamatorio producido por la inducción de PPAR- $\gamma$ y la producción de sus ligandos por la acción de la cascada IL-4/Stat6 (Thurner et al., 2006), puesto que la IL-4 es un elemento imprescindible para la diferenciación de monocitos a CD.

Los resultados relacionados con la $\mathrm{PGE}_{2}$ deben discutirse detalladamente a la vista de su relevante papel en la producción de IL-10 (Alvarez et al., 2009) y la potente inducción de COX-2 producida por el zymosan. Sin embargo, nuestros datos son poco concluyentes sobre el papel de $\mathrm{PGE}_{2}$ en la mediación del efecto de la fagocitosis de $\mathrm{CA}$, puesto que no observamos liberación de $A A$ ni expresión de COX-2, sino una inhibición de la producción de $\mathrm{PGE}_{2}$ en 
respuesta a las CA. Colectivamente estos datos no justifican la hipótesis de que la inducción de COX-2 y la producción de $\mathrm{PGE}_{2}$ jueguen un papel en la modulación de la producción de IL-10 inducida por las CA en CD.

\section{Efecto de la esfingosina-1-fosfato liberada por células apoptóticas sobre la producción de IL-10}

Se ha postulado que un mecanismo implicado en el reconocimiento de las CA es la liberación de mediadores solubles que ayudan a los fagocitos a migrar hacia los lugares donde se produce la apoptosis (Peter et al., 2010). Uno de los mediadores que intervienen en este proceso es la S1P. Gude y col. (2008) observaron que la S1P liberada por las CA es un factor quimiotáctico que facilita la fagocitosis de CA y el mantenimiento de la homeostasis. La S1P tiene otros efectos como la estabilización del ARNm de COX-2, el aumento de la expresión de la proteína y la formación de $\mathrm{PGE}_{2}$ en M $\varnothing$ murinos y humanos (Johann et al., 2008; Brecht et al., 2011), y el aumento de la liberación de IL-10 en CD maduras con capacidad inhibitoria de la respuesta de tipo Th1 (Idzko et al., 2002). Asimismo, varios estudios han descrito la contribución de la S1P liberada por las CA a la aparición del fenotipo anti-inflamatorio y a la supervivencia de los MØ (Weigert et al., 2006, 2007, 2009), junto con un aumento de la liberación de IL-8 e IL-10 y la inhibición de la producción TNF- $\alpha$ e IL-12 p70 tras el tratamiento con LPS + IFN- $\gamma$ (Weigert et al., 2007).

En el presente estudio, la liberación de S1P por CA se comprobó mediante cromatografía líquida acoplada a espectrometría de masas. Curiosamente, los niveles de S1P detectados fueron mayores en las células Jurkat tratadas con estaurosporina. A priori se podría pensar que el tratamiento seleccionado para inducir la apoptosis es un factor determinante de la inducción de S1P (Weigert et al., 2006; Johann et al., 2008; Brecht et al., 2011). Sin embargo, nuestros resultados han mostrado que la concentración de S1P liberada al medio no difiere significativamente tras ambos tratamientos y en ambos casos las concentraciones obtenidas son más bajas que las necesarias para observar un efecto comparable al de la S1P exógena. Estos datos indicarían que el efecto sinérgico de las CA sobre la producción de IL-10 no puede atribuirse al papel de la S1P. En nuestros experimentos con S1P y CA se pudo descartar el efecto autocrino de la $\mathrm{PGE}_{2}$ sobre la producción de IL-10 a pesar de que la S1P es capaz de incrementar la expresión de COX-2 en otros sistemas (Chalfant et al., 2005), puesto que no se observamos un aumento de la expresión de esta enzima y, contrariamente a lo esperado, la 
expresión de COX-2 se inhibió cuando S1P se combinó con otros estímulos. No obstante, sí observamos la expresión de los receptores $\mathrm{S}_{1} \mathrm{P}_{1 / 3}$ que se han relacionado con la inducción de COX-2 por Brecht y col. (2011). Dado que en el presente estudio no hemos podido demostrar un aumento de la expresión de COX-2, el efecto de la S1P sobre la producción de IL-10 debe atribuirse a otros mecanismos. 

Conclusiones 
1. Las células apoptóticas, per se, son estímulos débiles de la liberación de citoquinas; sin embargo, potencian significativamente la producción de IL-10 inducida por el zymosan e inhiben la liberación de IL-23, sin afectar la producción de IL-12 p70 inducida por el LPS y la combinación de LPS e IFN- $\gamma$.

2. EI TGF- $\beta$ no parece estar implicado en el efecto anti-inflamatorio ejercido por las células apoptóticas sobre las células dendríticas, a juzgar por los escasos niveles de producción detectados, mientras que en macrófagos las células apoptóticas liberan cantidades elevadas de TGF- $\beta$.

3. Los factores del complemento no parecen estar implicados en el reconocimiento de las células apoptóticas, lo que sugiere que sean otras opsoninas las implicadas en el efecto potenciador de la fagocitosis de CA producido por el suero.

4. La potenciación de la producción de IL-10 por $\mathrm{PGE}_{2}$ y la disminución de la producción por los inhibidores de PKA y de la ciclosporina A indican que el efecto de las células apoptóticas sobre la producción de IL-10 inducida por zymosan se regula por CREB a través de un mecanismo en cuyos pasos iniciales intervienen los receptores de prostanoides de la serie $E(E P)$ y la proteína quinasa $A$.

5. La disminución de la producción de IL-10 por la ciclosporina A sugiere la participación de CRTC2/TORC2 en la regulación transcripcional de il10, puesto que la translocación de este coactivador es dependiente de la actividad fosfatasa de la calcineurina.

6. Las células apoptóticas inducen la activación y translocación al núcleo del coactivador CRTC2/TORC2 y de la homeoproteína PBX1. Siendo este efecto más intenso en presencia de zymosan. La co-inmunoprecipitación de estas proteínas con P-CREB indicaría la interacción de estas tres proteínas en un complejo supramolecular que regularía la transcripción de il10.

7. La translocación de PPAR- $\gamma$ al núcleo indicaría la participación de este factor de transcripción en nuestro sistema. Sin embargo, no se puede afirmar su participación en la formación de cuerpos lipídicos ni en la síntesis de PGE2.

8. A diferencia de lo observado con zymosan, la producción de IL-10 por las CA no es dependiente de la inducción de COX-2 ni de la producción de $\mathrm{PGE}_{2}$

9. La esfingosina-1-fosfato incrementa los niveles de IL-10 producidos por el zymosan y las células apoptóticas tratadas con camptotecina. Este efecto no puede explicarse a través del sistema COX-2/PGE 2 . 

Bibliografía 
Akira S. 2011. "Innate Immunity and Adjuvants". Philosophical Transactions of The Royal Society B. 366 , pp: 2748-2755.

Akira S., Takeda K. 2004. "Toll-Like Receptor Signaling". Nature Reviews/ Immunology. 4, pp: 499-511.

Akpovi CD, Yoon SR, Vitale ML, Pelletier RM. 2006. "The Predominance of One of the SR-BI Isoforms is Associated With Increased Esterified Cholesterol Levels not Apoptosis in Mink Testis". Journal Lipid Research 47, pp: 2233-2247.

Albert M., Pearce S., Francisco L., Sauter B., Roy P., Silverstein R., Bhardwaj N. 1998. "Immature Dendritic Cells Phagocytose Apoptotic Cells via $a_{v} \beta_{5}$ and CD36, and Cross-Present Antigens o Cytotoxic T Lymphocytes". Journal Experimental Medicine. 188, pp: 1359-1368.

Alciato F., Sainaghi P., Sola D., Castello L., Avanzi G. 2010. "TNF-a, IL-6, and IL-10 Expression is Inhibited by Gas6 in Monocytes/Macrophages. Journal of Leukocyte Biology. 87, pp: 869.875.

Almeida P., Silva A., Maya-Montero C., Töröcsik., D’Ávila H., Dezsö B., Magalhães K., CastroFaria-Neto H., Nagy L., Bozza P. 2009. "Mycobacterium bovis Bacillus Calmette-Guérin Infection Induces TLR2-Dependent Peroxisome Proliferator-Activated Receptor Expression and Activation: Functions in Inflammation, Lipid Metabolism, and Pathogenesis". Journal of Immunology. 183, pp: 1337-1345.

Altarejo J., Montminy M., 2011. "CREB and The CRTC Co-activators: Sensors for Hormonal and metabolic signals". Nature Review/ Molecular Cell Biology. 12, pp: 141-151.

Alvarez Y., Municio C., Alonso S., Sánchez Crespo M., Fernández N. 2009. "The Induction of IL10 by Zymosan in Dendritic Cells Depends on CREB Activation by the Coactivators CREBBinding Protein and TORC2 and Autocrine PGE2". Journal of Immunology. 183, pp: 1471-1479.

Alvarez Y., Valera I., Municio C., Hugo E., Padrón F., Blanco L., Rodríguez M., Fernández N., Sánchez Crespo M. 2010. "Eicosanoids in the Innate Immune Response: TLR and non-TLR routes". Mediators of Inflammation". doi:10.1155/2010/201929, pp:1-14

Alvarez Y., Municio C., Hugo E., Zhu J., Alonso A., Hu X., Fernández N., Sánchez Crespo M. 2011. "Notch- and Transducing-like Enhancer of Split (TLE)-dependent Histone Deacetylation Explain Interleukin 12 (IL-12) p70 Inhibition by Zymosan". The Journal of Biological Chemistry. 286, pp: 16583-16595.

Amarilyo G., Verbovestski I., Grau A., Wiser G., Ben-Neriah Y., Mevorach D. 2010. "iC3bOpsonized Apoptotic Cells Mediate a Distinct Anti-inflammatory Response and Transcriptional NF-kappaB-Dependent Blockade". European of Journal Immunology. 40, pp: 699-709.

Ananieva O., Darragh J., Johansen C., Carr J.M., McllrathJ., Park J.M., Wingate A., Monk C.E. Toth R., Santos S.G., Iversen L., Arthur J.S. 2008. "The Kinases MSK1 and MSK2 Act as Negative Regulators of Toll-like Receptor Signaling". Nature Immunology. 9, pp:1028-1036.

Bailey S., Ghosh S. 2005. "PPAR'ting Ways with Inflammation. Nature Immunology. 6, pp: 966967. 
Banchereau J., Briere F., Caux C., Davoust J., Lebecque S., Liu Y., Pulendran B., Palucka K. 2000. "Immunobiology of Dendritic Cells". Annual Review of immunology. 18, pp: 767-811

Berdyshev E., Gorshkova I., Garcia J., Natarajan V., Hubbard W.2005. "Quantitative Analysis of Sphingoid Base-1-Phosphates as Bisacetylated Derivatives by Liquid Chromatography- Tandem Mass Spectrometry". Analytical Biochemistry. 339, pp: 129-136.

Blander J., Sander L. 2012. "Beyond Pattern Recognition: Five Immune Checkpoints for Scaling the Microbial Threat". Nature Review/lmmunology. 12, pp: 215-225.

Bonnefy F., Couturier M., Clauzon A., Rémy-Martin J., Gaugler B., Tiberghien P., Chen W., Saas P., Perruche S. 2011. "TGF- $\beta$ - Exposed Plasmacytoid Dendritic Cells Participate in Th17 Commitment". The Journal of Immunology. 186, pp: 6157-6164.

Bozza, P.T., Magalhães, K.G., Weller, P.F., 2009. "Leukocyte Lipid Bodies-Biogenesis and Functions in Inflammation". Biochemical and Biophysics Acta. 1791, pp: 540-551.

Bradford M. 1976. "A Rapid and Sensitive Method for Quantification of Microgram Quantites of Protein Utilizing the Principle of Protein-dye- Binding". Analytical Biochemistry. 72, pp: 248-254.

Brereton C., Blander M. 2010. "Responding to Infection and Apoptosis -a Task for TH17cell".Annals of the New York Academy of Science. 1209, pp:56-67

Brecht K., Weigert A., Hu J., Popp R., Fissslthaler B., Korft., Fleming I., Geisslinger G., Brúne B. 2011. "Macrophages Programmed by Apoptotic Cells Promote Angiogenesis via Prostaglandin $\mathrm{E}_{2}$ ". The FASEB Journal. 25, pp: 2408-2417.

Brown G.D. 2006. "Dectin-1: A Signaling non-TLR Pattern-Recognition Receptor". Nature Reviews Immunology. 6, pp: 33-43.

Brown G.D. 2010. "How Fungi Have Shaped our Understanding of mammalian Immunology" Cell Host \& Microbe. 7, pp: 9-11

Brown, G.D., Herre, J., Williams, D.L., Willment, J.A., Marshall, A.S., Gordon, S., 2003. "Dectin-1 Mediates the Biological Effects of $\beta$-glucans". Journal Experimental Medicine 197, pp: 11191124.

Böse J., Gruber A.D., Helming L., Schibe S., Wegener I., Hafner M., Beales M., Köntagen F., Lengeling A. 2004. "The Phosphatidylserine Receptor has Essential Functions During Embryogenesis but Not in Apoptotic Cell Removal". Journal of Biology. 3, pp: 15

Cambi A., Figdor C. 2009. "Necrosis: C-Type Lectins Sense Cell Death". Current Biology. 19, pp:375-378

Chalfant C., Spigel S. 2005. "Sphingosine-1-Phosphate and Ceramide-1- Phosphate Expanding Roles in Cell Signaling. Journal of Cell Science. 118, pp: 4605-4612.

Chung E., Liu J., Homma Y., Zhang Y., Brendolan A., Saggese M., Han J., Silverstein R., Selleri L., Ma X. 2007. "Interleukin-10 Expression in Macrophages During Phagocytosis of Apoptotic Cells is Mediated by Homeodomain Proteins Pbx1 and Prep-1". Immunity. 27,. pp: 952-964. 
Chung, S., Gumienny, T.L., Hengartner, M.O., Driscoll, M., 2000. "A Common Set of Engulfment Genes Mediates Removal of Both Apoptotic and Necrotic Cell Corpses in C. elegans". Nature Cell Biology. 2, pp: 931-937.

Cvetanovic M., Uscker DS., 2004. "Innate Immune Discrimination of Apoptotic Cells: Repression of Proinflammatory Macrophage Transcription Is Coupled Directly to Specific Recognition". The Journal of Immunology. 172, pp: 880-889.

Cvetanovic M., Mitchell J.E. Patel V., Avner BS., Su Y., van der Saaq P.T. Witte P.L. Fiore S., Levine J. S., Uscker D.S. 2006. "Specific Recognition of Apoptotic Cells Reveals a Ubiquitous and Unconventional Innate Immunity" The Journal of Biological Chemistry.281, pp: 20055-20067.

Dall'Asta M., Derlindati E., Ardigò D., Zavaroni I., Brighenti F., Del Rio D. 2012. "Macrophage Polarization: The Answer to the Diet/Inflammation Conundrum?". 22, pp: 387-392.

Dennehy K., Willment J., WilliamsD., Brown G. 2009. "Reciprocal Regulation of IL-23 and IL-12 Following Co-Activation of Dectin-1 and TLR Signaling Pathways". European Journal of Immunology. 39, pp: 1379-1386.

Devitt A., Pierce S., Oldreive C., Shingler WH., Gregory CD. 2003. "CD14-dependent Clearance of Apoptotic Cells by Human Macrophages: The Role of Phosphatidylserine". Cell Death and Differentiation. 10, pp: 371-382,

De Assis, EF., Silva AR., Caiado LF., Marathe GK., Zimmerman GA., Prescott SM., Mclntyre TM., Bozza PT., de Castro-Faria-Neto HC. 2003. "Synergism Between Platelet-Activating FactorLike Phospholipids and Peroxisome Proliferator-Activated Receptor-y Agonists Generates During Low Density Lipoprotein Oxidation that Induces Lipid Body Formation in Leukocytes". The Journal of Immunology. 171, pp: 2090-2098.

De la Rosa G., Yáñez-Mó M., Serrano D., Martínez L., Fernadez-Ruíz E., Longo N., SánchezMadrid F., Corbi A., Sáchez-Mateos P. 2005. "Regulated Recruitment of DC-SIGN to cell - cell Contact Regions During Zymosan-induced Human Dendritic Cell Aggregation". Journal of Leukocyte Biology. 77, pp: 699-709.

Dillon S., Agrawal S., Banerjee K., Letterio J., Denning T., Oswald-Ritcher K., Kasprowicz D., Kellar K., Pare J., van Dyke T., Ziegler S., Unutmaz D., Pulendra B. 2006. "Yeast Zymosan, a Stimulus for TLR 2 and Dectin-1, Induce Regulatory Antigen- Presenting Cells and Immunological Tolerance". The Journal of Clinical Investigation. 116, pp: 916-928

Drickamer K. 1988. "Two Distinct Classes of Carbohydrate-Recognition Domain in Animal Lectins". The Journal of Biological Chemistry. 263, pp: 9557-9560.

Drickramer K. 1999. "C-Type Lectin-Like Domains". Current Opinion in Structural Biology. 9, pp:585-590

Eggleton P., Gargan R., Fisher D. 1989. "Rapid Method for the Isolation of Neutrophils in High Yield Without the Use of Dextran or Density Gradient Polymers". Journal Immunological Methods. 121, pp: 105-13. 
Erwig L-P., Henson PM. 2008. "Clearance of Apoptotic Cells by Phagocytes". Cell Death and differentiation.15, pp: 243-250.

Fadok V., Voelker D., Campbell P., Cohen J., Bratton D., Henson P. 1992. "Exposure of Phosphatidylserine on the Surface of Apoptotic Lymphocytes Triggers Specific Recognition and Removal by Macrophages". Journal of Immunology. 148, pp: 2207-2216.

Fadok V., Bratton D., konowal A., Freed A., Freed P., Westcott J., Henson P. 1998. "Macrophages That Have Ingested Apoptotic Cells In Vitro Inhibit Proinflammatory Cytokine Production Autocrine/Paracrine Mechanisms Involving TGF- $\beta, \mathrm{PGE}_{2}$, and PAF. The Journal of Clinical Investigation. 101, pp: 890-898.

Franc N.C., White K., Ezekowitz A.1999. "Phagocytosis and Development: Back to the Future". Current Opinion in Immunology. 11. pp: 47-52.

Freire-de-Lima C., Xiao Y., Gardai S., Bratton D., Schiemann W., Henson P. 2006. "Apoptotic Cells, Through Transforming Growth Factor- $\beta$, Coordinately Induce Anti-inflammatory and Suppress Pro-inflammatory Eicosanoid and NO Synthesis in Murine Macrophages". The Journal of Biological Chemistry. 281, pp: 38376-38384.

Gantner, B.N., Simmons, R.M., Canavera, S.J., Akira, S., Underhill, D.M., 2003. "Collaborative Induction of Inflammatory Responses by Dectin-1 and Toll-like Receptor 2". Journal Experimental Medicine. 197, pp: 1107-1117.

Gautier G., Humbert m., Deauvieau F., Scuiller M., Hiscott J., Bates E., Trinchieri G., Caux C., Garrone P. 2005. "A Type I Interferon Autocrine-Paracrine Loop is Involved in Toll Like ReceptorInduce Interleukin-12p70 Secretion by Dendritic Cells" Journal Experimental Medicine.201, pp:1435-1446.

Geissmann F. [1], Markus M., Jung S., Sieweke M., Merad M., Ley K., 2010. "Development of Monocytes, Macrophages and Dendritic Cells". Science. 327, pp: 656-661.

Geissmann F. [2], Gordon S., Hume D., Mowart A., Randolph G. 2010. "Unravelling Mononuclear Phagocyte Heterogeneity" Nature Review Immunology. 10, pp: 453-460

Geijtenbeek T., Torensma R., van S., Van Duijnhoven G., Adema G., Kooyk Y. 2000. "Identification of DC-SIGN, a Novel Dendritic Cell-Specific ICAM-3 Receptor that Supports Primary Immune Responses". Cell. 100, pp: 575-585.

Geijtenbeek T., Gringhuis S. 2009. "Signaling Though C-type Lectin Receptor: Shaping Immune Responses". Nature Reviews Immunology. , pp: 465-479.

Goh, S.L., Looi, Y., Shen, H., Fang, J., Bodner, C., Houle, M., Ng, A., Screaton, R.A., Featherstone, M., 2009. "Transcriptional Activation by MEIS1A in Response to Protein Kinase A Signaling Sequires the Transducers of Regulated CREB Family of CREB Co-activators". Journal of Biological Chemistry. 284, pp: 18904-18912.

Gordon, S., Martinez, F.O. 2010. Alternative Activation of Macrophages: Mechanism and Functions. Immunity. 32, pp: 593-604. 
Gordon S., Taylor P., 2005. "Monocyte and Macrophage Heterogeneity". Nature Reviews/ Immunology. 5, pp: 953-968.

Green D., Ferguson T., Zutvolgel L., Kroemer G., 2009. "Immunogenic and Tolerogenic Cell Death" Nature Review/ Immunology. 5, pp. 353-363

Gregory C. 2000. "CD14-dependent Clearance of Apoptotic Cells: Relevance to the Immune System". Cell. 12, pp: 27-34.

Gringhuis S., Den Dunnen J., Litjens M., van het Hof B., van Kooyk Y., Geijtenbeek T. 2007. "CType Lectin DC-SIGN Modulates Toll- like Receptor Signaling via Raf-1 Kinase- Dependent Acetylation of Transcription Factor NF-кB. Immunity. 26, pp: 605-616.

Gude D., Alvarez S., Paugh S., Mitra P., Yu J., Griffiths R., Barbour S., Milstien S., Spigel S. 2008. "Apoptosis Induces Expression of Sphingosine Kinase 1 to Release Sphingosine-1Phosphate as a "Come-and-Get-me" Signal". The FASEB Journal. 22, pp: 2629-2638.

Hagiwara M., Brindle P., Harootunian A., Armstrong R., Rivier J., Vale W., Tsien R., Mntminy M.1993. "Coupling of Hormonal Stimulation and Transcription Via the Cyclic AMP- Responsive Factor CREB is Rate Limited by Nuclear Entry of Protein Kinase A". Molecular and Cellular Biology. 13, pp: 4852-4859.

Han-Jung C., Kang J., Byun J., Han K., Kim D., Oh S., Kim H., Chae S., Kim H. 2000. "Molecular Mechanism of Staurosporine-Induced Apoptosis in Osteoblasts" 42, pp: 373-381.

Hardison S., Brown G. 2012. "C-type Lectin Receptors Orchestrate Antifungal Immunity". Nature Review Immunology. 13, 817-822

Harris S., Padilla J., Kousmas L., Ray D., Phipps R. 2002. "Prostaglandins as Modulators of Immunity". TRENDS in Immunology. 23, pp: 144-150.

Heinsbroek S., Taylor P., Rosas M., Willment J., Williams D., Gordon S., Brown G. 2006. "Expression of Functionally Different Dectin-1 Isoforms by Murine Macrofages".Journal Immunology. 176, pp: 5513-5518

Huysamen C., Willment J., Dennehy K., Brown G.2008. "CLE9A is A Novel Activation C-Type Lectin- Like Receptor Expressed on BDCA3 ${ }^{+}$Dendritic Cells Subset of Monocytes" The Journal of Biological Chemistry. 13, pp: 16693-16701

Hölscher C. 2004. "The Power of Combinatorial Immunology: IL-12 and IL-12-Related Dimeric Cytokines in Infectious Diseases". Medical Microbiology and Immunology. 193, pp: 1-17

Idzko M., Panther E., Coriti S., Morelli A., Ferrari D., Herouy Y., Dichmann S., Mockenhaupt M., Gebicke- Haerter P., Di Virgilio F., Girolomoni G., Norgauer J. 2002. "Sphingosine-1- phosphate Induce Chemotaxis of Immature and Modulates Cytokine-release in Mature Human Dendritic Cells for Emergence of Th2 Immune Responses". The Faseb Journal. 16, pp: 625-627. 
Ip W., Lau YL. 2004. "Distinct Maturation of, but Not Migration Between, Human MonocyteDerived Dendritic Cells Upon Ingestion of Apoptotic Cells of Early or Late Phases". The Journal of Immunology. 17, pp: 189-196.

Ishii K., Koyama S., Nakagawa A., Coban C., Akira S. 2008. "Host Innate Immune Receptor and Beyond: Making sense of Microbial Infections". Cell Host \& Microbe/ Review. 3, pp:352-363.

Janeway C.A., Medzhitov R. 2002. "Innate Immune Recognition". Annual Review in Immunology. 20, pp: 197-216

Jakus Z., Fodor S., Abram C., Lowell C., Mócsai A. 2007. "Immunoreceptor-like signaling by $\beta_{2}$ and $\beta_{2}$ integrins". 17, pp: 493-496.

Jeanni P., Jaillon S., Delneste Y. 2008. "Pattern Recognition Receptor in The Immune Response Against Dying Cells". Current Opinion in Immunology. 20, pp: 1-8.

Jeong E., Lee J. 2011. "Intrinsic and Extrinsic Regulation of Innate Immune Receptors". Yonsei Medical Journal. 52, pp: 379-392.

Johann A., Weigert A., Eberhardt W., Kuhn AM., Barra V., von Knethen A., Pfeilschifter J., Büne B. 2008. "Apoptotic Cell-Derived Sphingosine-1-Phosphate Promotes HuR-Dependent Cyclooxygenase-2 mRNA Stabilization and Protein Expression". The Journal of Immunology. 180, pp: $1239-1248$.

Kalinski P., Vieira P., Schuitemaker J., Jong E., Kapsenberg M. 2001. "Prostaglandin $E_{2}$ is a Selective Inducer of Interleukin-12 p40 (IL-12 p40) Production and Inhibitor of Bioactive IL-12p70 Heterodimer". Blood. 97, pp:3466-3469.

Kang Y., Wingerd B., Smith W. 2006. "Cyclooxygenase-2 Gene Transcription in a Macrophage Model of Inflammation". The Journal of Immunology.177, pp: 8111-8122.

Katoh Y., Takemori H., Lin X., Tamura M., Muraoka M., Satoh T., Tsuchiya Y., Min L., Doi J., Miyauchi A., Witters L., Nakamura H., Okamoto M. 2006. "Silencing the Constitutive Active Transcription Factor CREB by the LKB1-SIK signaling Cascade". The FEBS Journal. 273, pp:2730-2748.

Kee B., Arias J., Montminy M. 1996. "Adaptor-mediated Recruitment of RNA Polymerase II to a Signal-Dependent Activator". The Journal of Biological Chemistry. 271, pp: 2373-2375.

Kerringa A., Brown G.2011. "Syk-Coupled C- type Lectins in Immunity". Cell. 32, pp: 151-156.

Kim S., Elkon K., Ma X. 2004. "Transcriptional Suppression of Interleukin-12 gene Expression Following Phagocytosis of Apoptotic Cells". Immunity. 21, pp: 643-653

Kobayashi S.D.,De Leo F.R., 2009. "Role of Neutrophils in Innate Immunity: A Systems BiologyLevel Approach". Wiley Interdisciplinary Reviews: Systems Biology and Medicine.1, pp: 309-333.

Kozmar A., Greenlee-Warcker M., Bohlson S. 2010. "Macrophage Response to Apoptotic Cells Varies With The Apoptotic Trigger and Is Not Altered by a Deficiency in LRP Expression". Journal of Innate Immunity. 2, pp: 248-259. 
Laemmli U. K. 1970. "Cleavage of Sstructural Proteins During the Assembly of the Head of Bacteriophage T4". Nature. 227, pp: 680-685.

Legler D., Bruckner M., Uetz-von E., Krause P. 2010. "Prostaglandin $E_{2}$ at New Glance: Novel Insight in Functional Diversity Offer the Therapeutic chances". The International Journal of Biochemistry \& Cell Biology. 42, pp: 198-201.

Lu Y-C., Yeh W-C., Ohashi P., 2008. "LPS/TLR4 Signal Transduction Pathway". Cytokine. 42. pp:145-151.

Lui Y., Dentin R., Chen D., Hedrick S., Ravnskjaer K., Shenk S., Milne J., Meyers DJ. Cole P., Yates $3^{\text {rd }}$, Olefsky J., Guarente L., Montminy M., 2008. "A Fasting Inducible Switch Modulates Gluconeogenesis via Activator/Coactivator Exchange". Nature. 465, pp: 269-273.

Lyakh L. Trinchieri G., Provezza L. Carra G., Gerosa F. 2008 . "Regulation of Interleukin12/interleukin-23 Production and the T-helper 17 Response in Humans". Immunological reviews. 226, pp: 112-131.

Macey M.G. 2007. "Apoptosis Detection by Flow Cytometry in Flow Cytometry: Principles and Applications". Edited by: Humana Press Inc., Totowa, NJ.

Maderna P., Godson C. 2003. "Phagocytosis of Apoptotic Cells and the Resolution of Inflammation". Biochemical et Biophysica Acta. 1639, pp: 141-151.

Martinez, F.O., Sica, A., Mantovani, A., Locati, M. 2008. "Macrophage Activation and Polarization". Frontiers in Bioscience. 13, pp: 453-461.

Mattos, K.A., D'Avila, H., Rodrigues, L.S., Oliveira, V.G., Sarno, E.N., Atella, G.C., Pereira, G.M., Bozza, P.T., Pessolani, M.C. 2010. "Lipid Droplet Formation in Leprosy: Toll-like Receptorregulated Organelles Involved in Eicosanoid Formation and Mycobacterium leprae Pathogenesis. Journal of Leukocyte Biology. 87, pp: 371-384.

Means, T.K., Mylonakis, E., Tampakakis, E., Colvin, R.A., Seung, E., Puckett, L., Tai, M.F., Stewart, C.R., Pukkila-Worley, R., Hickman, S.E., Moore, K.J., Calderwood, S.B., Hacohen, N., Luster, A.D., El Khoury, J., 2009. "Evolutionarily Conserved Recognition and Innate Immunity to Fungal Pathogens by the Scavenger Receptors SCARF1 and CD36". Journal of Experimental Medicine. 206, pp: 637-653.

Medeiros A., Serezani C., Pyo Lee S, Peters-Golden M. 2009. "Efferocytosis Impairs Pulmonary Macrophage and Antibacterial Function and Lung via PGE2/EP2 signaling". Journal of Experimental Medicine. 206, pp: 61-68.

Medzhitov R., 2009. “Approaching the Asymptote: 20 years later". Immunity. 6, pp: 766-775.

Medzhitov R., 2007. "Recognition of Microorganism and Activation of the Immune Response". 449. Immunity, pp: 819-826.

Mellett, M., Atzei, P., Jackson, R., O'Neill, L.A., Moynagh P.N. 2011. "Mal Mediates TLR-induced Activation of CREB and Expression of IL-10".Journal of Immunology, 186: 4925-4935. 
Mevorach D., Mascarenhas J., Gershov D. 1998. "Complement-Dependet Clearance of Apoptotic Cells by Human Macrophages”. Journal of Experimental Medicine. 88, pp: 2313-2320.

Miyanishi M, Tada K, Koike M., Uchiyama Y., Kitamura T., Nagata S. 2007. "Identification of Tim4 as a Phosphatidylserine Receptor". Nature. 450, pp:435-439

Mosser D., Zhang X. 2008."Interleukin-10: New Perspectives on an Old Cytokine”. Immunological Reviews. 226, pp: 205-218.

Mosser D., Edwards J., 2008. "Exploring the Full Spectrum of Macrophage Activation". Nature Review Immunology. 12, pp: 958-56

Nauta A., Daha M., Kooten C., Roos A. 2003. "Recognition and Clearance of Apoptotic Cell: a Role for Complement and Petraxins." Trends in Immunology. 24, pp: 148-154.

Nauta A., Castellanos G., Xu G., Woltman A., Borrias M., Dah M., Kooten CV., Roos A. 2004. "Opsonization with C1q and Mannose- Binding Lectin Targets Apoptotic Cells to Dendritic Cell". The Journal of Immunology. 173, pp: 3044-3050.

Netea M., Grow N., Murno C., Bates S., Collins C., Ferwerda G., Hobson R., Bertram G., Hughes B., Jansen T., Jacobs L., Buurman E., Gijzen K., Williams D., Torensma R., Mc., Donna M., Frank O., Van Der M., Alistair B., Bart K. 2006. "Immune Sensing of Candida albicans Requires Cooperative Recognition of Mannans and Glucans by Lectin and Toll-like Receptors". The Journal of Clinical Investigation.116, pp: 1642-1650.

Netea M., Brown G.D., Kullberg B. J., Gow A.R. 2008. "An Integrated Model of the Recognition of Candida albicans by the Innate Immune System". Nature Review of Microbiology. 6.,pp: 67-78.

Osorio F., Sousa C. 2011. "Myeloid C-type Lectin Receptor in Pathogen Recognition and Host Defense". Inmmunity. 34, pp:651-664.

Pacheco O., Bozza FA., Gomes RN., Bozza M., Weller PF., Castro-Faria-Neto HC., Bozza PT. 2002. "Lipopolysaccharide-Induce Leukocyte Lipid Body Formation in Vivo: Innate Immunity Elicited Intracellular Loci Involved in Eicosanoid Metabolism". The Journal of Immunology. 169, pp: 6498-6506.

Peter C., Wesselborg S., Lauber K. 2010. "Molecular Suicide Notes: Last Call From Apoptosing Cells". Journal of Molecular Cell Biology. 2, pp: 78-80.

Pizzolato J., Saltz L. 2003. “The Camptotecins”. Lancet. 361, pp: 2235-2242.

Radhakrishnan I., Pérez-Alvarado G., Dyson J., Montminy M., Wright P. 1997. "Solution Structure of the KIX Domain of CBP Bound to the Transactivation Domain of CREB: A Model for Activator: Coactivator Interactions". Cell. 91, pp: 741-752.

Romani L. 2011.“Immunity to Fungal Infections”. Nature Reviews/ Immunology.4, pp: 11-24.

Rothlin C., Ghosh S., Zuniga E., Oldstone M., Lemke G. 2007. "TAM Receptors are Pleiotropic Inhibitors of the Innate Immune Response". 131, pp: 1124-1136. 
Sancho D., Joffre O., Keller A., Roger A., Martínez D., Hernanz- Falcón P., Rosewell I., Reis e Sousa C. 2009. "Identification of a Dendritic Cell Receptor that Couples sensing of Necrosis to Immunity”. Nature. 45, pp: 899-903.

Savill J, Dransfield I, Gregory C, Haslett C. 2002. "A Blast From The Past: Clearance of Apoptotic Cells Regulates Immune Responses". Nature Reviews Immunology, 2, pp: 965-975.

Sen P., Wallet M., Yi Z., Huang Y., Henderson M., Mathews C., Earp S., Matsushima G., Baldwin A., Tisch R. 2006. "Apoptotic Cells Induce Mer Tyrosine Kinase-Dependent Blockade of NF-kB Activation in Dendritic Cells". Blood. 109, pp: 653-660.

Screaton R., Conkright M., Katoh Y., Best J., Canattieri G., Jeffries S., Guzman E., Niessen S., Yates III J., Takemori H., Okamoto M., Montminy M. 2004. "The CREB Coactivator TORC2 Functions as a Calcium- and cAMP-Sensitive Coincidende Detector". Cell. 119, pp: 61-74

Sheibanie A., Tadmori I., Vassiliou E., Ganea D. 2004. "Prostaglandin E2 Induces IL-23 Production in Bone Marrow Derived Dendritic Cells".FASEB. 18, pp:1318-1320.

Suram S., Gangelhoff T., Taylor P., Rosas M., Brown G., Bonventre J., Akira S., Uematsu S., WIllians D., Murphy R., Leslie C. 2010: "Pathway Regulating Cytosolic Phospholipase A2 Activation and Eicosanoid Production in Macrophagers by Candida albicans". The Journal of Biological Chemistry. 285.40 pp:30676-30685.

Steinman R. and Cohn Z. 1973 "Identification of Cell Type in Peripherial Lymphoid Organs of Mice". The Journal Experimental Medicine.173, pp: 1142-1160.

Sorgi, C.A., Secatto, A., Fontanari, C., Turato, W.M., Belangér, C., de Medeiros, A.I., Kashima, S., Marleau, S., Covas, D.T., Bozza, P.T., Faccioli, L.H. 2009. "Histoplasma capsulatum Cell Wall $\beta$-glucan Induces Lipid Body Formation Through CD18, TLR2, and Dectin-1 Receptors: Correlation with Leukotriene B4 Generation and role in HIV-1 infection". Journal of. Immunology. 182, pp: 4025-4035.

Szatmari, I., Töröcsik, D., Agostini, M., Nagy, T., Gurnell, M., Barta, E., Chatterjee, K., Nagy, L. 2007. "PPAR-y Regulates the Function of Human Dendritic Cells Primarily by Altering Lipid Metabolism. Blood. 110, pp: 3271-3280.

Takeda K., Akira S. 2005. "Toll-Like Receptor in Innate Immune". The Japanese Society for Immunology. 17, pp: 1-4.

Takeuchi O., Akira S. 2010 ."Pattern Recognition Receptors and Inflammation." Cell. 140, pp: 805-820.

Taylor P., Martinez-Pomares M., Lin HH., Brown GD., Gordon S. 2005. " Macrophages Receptors and Immune Recognition". Annual Review of immunology. 23, pp: 901-944.

Taylor R.C., Cullen S.P., Martin S. 2008. "Apoptosis: Controlled Demolition at the Cellular Level". Nature Review/Molecular Cell Biology. 9, pp: 231-241.

Tato C., Cua D. 2008. "Reconciling id, ego, and Superego Within Interleukin-23. Immunological Reviews. 226, pp: 103-111. 
Thurner M. 2006. "Lipids in Dendritic Cell Biology: Messengers, Effectors, and Antigens".Leukocites Biology. 81, pp: 154-160.

Torchinsky M., Garaude J., Blander M. 2009. "Infection and Apoptosis as a Combined Inflammatory Trigger". Current Opinion in Immunology. 22, pp:55-62.

Trinchieri G. 1997. "Cytokines Acting on or Secreted by Macrophages During Intracellular Infection (IL-10, IL-12, IFN-y)". Current Opinion in Immunology. 9, pp: 17-23.

Vargas, T., Nagy, L. 2008. "Nuclear Receptors, Transcription Factors Linking Lipid Metabolism and Immunity: The Case of Peroxisome Proliferator-Activated Receptor Gamma". European Journal of Clinical Investigation. 38, pp: 695-707.

Vo, N., Goodman, R.H. 2001. "CREB-binding Protein and p300 in Transcriptional Regulation". Journal of. Biological Chemistry. 276, pp: 13505-13508.

Wang, Z., Iwasaki, M., Ficara, F., Lin, C., Matheny, C., Wong, S.H., Smith, K.S., Cleary, M.L., 2010. "GSK-3 Promotes Conditional Association of CREB and Its Coactivators with MEIS1 to Facilitate HOX-Mediated Transcription and Oncogenesis. Cancer Cell. 17, pp: 597-608.

Weck M., Appel S., Weth D., Sinzger C., Bringmann A., Grünebach F., Brossart P. 2008. "hDectin-1 is Involved in Uptake and Cross-presentation of Celullar Antigens. Blood. 111, pp: 42644272.

Weigert A., Johann A., Knethen A., Schmidt H., Geisslinger G., Brüne B. 2006. "Apoptotic Cells Promote Macrophage Survival by Releasing The Antiapoptotic Mediator Sphingosine-1Phosphate". Blood. 108, pp: 1635-1642.

Weigert A., Tzieply N., von Knethen A., Johann A., Schmindt H., Geisslinger G., Brüne B. 2007. "Tumor Cell Apoptosis Polirizes Macrophages- Role of Sphingosine-1- Phosphate". Molecular Biology of the Cell. 18, pp: 3810-3819.

Weigert A., Weis N., Brüne B. 2009. "Regulation of Macrophage Fuction by Sphingosine-1Phosphate". Immunobiology. 214, pp: 748-760.

Weis W., taylor M., Drickamer K. 1998. "The C-type Lectin Superfaily in the Immune System". Immunological Reviews. 163, pp:19-34.

Willment, J.A., Gordon, S., Brown, G.D. 2001. "Characterization of the Human Beta -Glucan Receptor and its Alternatively Spliced Isoforms". Journal of Biological Chemistry. 276, pp: 4381843823.

Willment, J.A., Lin, H.H., Reid, D.M., Taylor, P.R., Williams, D.L., Wong, S.Y., Gordon, S., Brown, G.D. 2003. "Dectin-1 Expression and Function are Enhanced on Alternatively Activated and GMCSF-Treated Macrophages and are Negatively Regulated by IL-10, Dexamethasone, and Lipopolysaccharide". Journal of Immunology. 171, pp: 4569-4573.

Willment J., Brown GD. 2007. "C-type Lectin Receptors in Antifungal Immunity". Trends in Microbiology.16, pp: 27-32. 
Zelensky A., Gready J. 2005. "The C-Type Lectin- like Domain Superfamily". The FEBS Journal. 272, pp: 6179-6217.

Zhang Y., Kim HJ., Yamamoto S., Kang X., Ma X. 2010. "Regulation of Interleukin-10 Gene Expression in Macrophages Engulfing Apoptotic Cells". Journal of Interferon \& Cytokine Research. 30, pp: 113-121.

Zhang J., Czabotar P., Policheni A., Caminschi I., Wan S., Kitsoulis S., Tullet K., Robin A., Brammananth R., van Delf M., Lu J., O'Reilly L., Josefsson E., Kile B., Chin W., Mintern J., Olshina M., Wong W., Baum J., Wright M., Huang D., Mohandas N., Coppel R., Colman P., Nicola N., Shortman K., Lahoud M. 2012. "The Dendritic Cell Receptor Clec9A Binds Damaged Cells via Exposed Actin Filaments". Immunity 36, pp: 1-12.

Zhou, Z., Hartwieg, E., Horvitz, H.R., 2001. "CED-1 is a Transmembrane Receptor that Mediates Cell Corpse Engulfment in C. elegans". Cell. 104, pp: 43-56.

Ziegenfuss, J.S., Biswas, R., Avery, M.A., Hong, K., Sheehan, A.E., Yeung, Y.G., Stanley, E.R., Freeman, M.R., 2008. "Draper-dependent Glial Phagocytic Activity is Mediated by Src and Syk Family Kinase Signaling". Nature. 453, pp: 935-939. 

Anexo I 
Durante la realización de la tesis he participado en diferentes proyectos de investigación que han dado lugar a las siguientes publicaciones:

Alvarez Y., Rodríguez M., Municio C., Hugo E., Alonso S., Ibarrola N., Fernández N., Crespo MS. 2012. "Sirtuin 1 Is a Key Regulator of the Interleukin-12 p70/Interleukin-23 Balance in Human Dendritic Cells". The Journal of Biological Chemistry. 286, pp: 35689-35701

* Municio, C., Hugo, E., Alvarez, Y., Alonso, S., Blanco, L., Fernández, N., Sánchez Crespo, M. 2011. "Apoptotic cells enhance IL-10 and reduce IL-23 production in human dendritic cells treated with zymosan". Molecular Immunology. 49, pp: 97-106

Alvarez, Y., Municio, C., Hugo, E., Zhu, J., Alonso, S., Hu, X., Fernández, N., Sánchez Crespo, M. 2011. "Notch- and transducin-like enhancer of split (TLE)-dependent histone deacetylation explain interleukin 12 (IL-12) p70 inhibition by zymosan". The Journal Biological Chemistry. 286, pp: $16583-95$.

Alvarez, Y., Valera, I., Municio, C., Hugo, E., Padrón, F., Blanco, L., Rodríguez, M., Fernández, N., Crespo, M.S. 2010. "Eicosanoids in the innate immune response: TLR and non-TLR routes". Mediators of Inflammation. doi:10.1155/2010/201929.

Municio, C., Alvarez, Y., Montero, O., Hugo, E., Rodriguez, M., Alonso, S., Fernández, N., Sánchez Crespo, M. "The response of human macrophages to $\beta$-glucans depends on the microenvironment". In Press

Rodríguez M., Domingo E., Municio C., Alvarez Y., Hugo E., Fernandez N., Sánchez Crespo M. "Receptor and signaling involved in eicosanoid production in the innate immune response". Manuscrito en preparación.

* Trabajo publicado sobre el tema específico de la tesis. 

Anexo II 


\title{
Apoptotic cells enhance IL-10 and reduce IL-23 production in human dendritic cells treated with zymosan
}

\author{
Cristina Municio a, ${ }^{\mathrm{a}}$, Etzel Hugo ${ }^{\mathrm{a}, 1}$, Yolanda Alvarez ${ }^{\mathrm{a}}$, Sara Alonso ${ }^{\mathrm{a}}$ Lydia Blanco $^{\mathrm{b}}$, \\ Nieves Fernández ${ }^{\mathrm{c}, 1}$, Mariano Sánchez Crespo ${ }^{\mathrm{a}, *, 1}$ \\ a Instituto de Biología y Genética Molecular, Consejo Superior de Investigaciones Científicas, Valladolid, Spain \\ b Centro de Hemoterapia y Hemodonación de Castilla y León, Valladolid, Spain

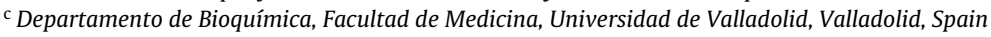

\section{A R T I C L E I N F O}

\section{Article history:}

Received 18 March 2011

Received in revised form 27 July 2011

Accepted 28 July 2011

Available online 26 August 2011

\section{Keywords:}

CREB

Dectin-1

PBX1

Prostaglandins

PPAR- $\gamma$

\begin{abstract}
A B S T R A C T
Contact of apoptotic cells (AC) with phagocytes tilts the balance of pro-inflammatory and antiinflammatory cytokines. To address the cell- and stimulus-dependency of this mechanism, human monocyte-derived dendritic cells were treated with Jurkat $A C$ in the presence and absence of different stimuli. AC reduced the production of IL-23 and enhanced the production of IL- 10 elicited by zymosan, but they did not influence IL-12 p70 production nor did they modify the effect of LPS. Since formation of lipid bodies (LB) and $\mathrm{PGE}_{2}$ production have been associated with IL-10 induction, the effect of $\mathrm{PGE}_{2}$, the formation of LB, and the role of PPAR- $\gamma$ were assessed. Exogenous $\mathrm{PGE}_{2}$ enhanced IL-10 expression, but no evidence of $\mathrm{PGE}_{2}$ production elicited by AC was obtained. Inhibition of PPAR- $\gamma$ activity reduced the production of IL- 10 both in the presence and in the absence of AC, but formation of LB in response to zymosan and $A C$ was not observed. Notably, AC induced a transient nuclear translocation of both the CREB coactivator CRTC2/TORC2 and the homeodomain protein PBX1, which are involved in the CREB/HOX/PBX/MEIS transcription complex. These data show a selective effect of $A C$ on the production of cytokines elicited by the fungal surrogate zymosan through the enhancement of CREB-dependent transcription.
\end{abstract}

(C) 2011 Elsevier Ltd. All rights reserved.

\section{Introduction}

Removal of apoptotic cells (AC) has been recognized as a central mechanism controlling tissue damage during the inflammatory response (for review, see Elliott and Ravichandran, 2010). Early attempts to characterize the chemical mediators involved in this regulatory role focussed on TGF- $\beta$, platelet-activating factor, and $\mathrm{PGE}_{2}$ (Fadok et al., 1998), but most recently, modulation of the IL12 p70/IL-10 balance seems to be the most relevant mechanism (Kim et al., 2004). Most studies have focussed on the phagocytosis of AC by macrophages, but defining the array of cell-specific

Abbreviations: AA, arachidonic acid; AC, apoptotic cells; CBP, CREB binding protein; COX-2, cyclooxygenase-2; CRE, cyclic AMP response element; CREB, CRE binding protein; CRTC2, CREB-regulated transcription coactivator; DC, dendritic cells; FBS, fetal bovine serum; HIHS, heat-inactivated human serum; LB, lipid bodies; MEIS, myeloid ecotropic viral integration site; MFI, geometric mean fluorescence intensity; NHS, normal human serum; PBX1, pre-B-cell leukemia homeobox 1; $\mathrm{PGE}_{2}$, prostaglandin $E_{2}$; PKA, protein kinase A; TBP, TATA box-binding protein; TORC2, transducer of regulated CREB activity 2 .

* Corresponding author at: Instituto de Biología y Genética Molecular, C/Sanz y Forés 3, 47003-Valladolid, Spain. Tel.: +34 983 423273; fax: +34 983184800.

E-mail address: mscres@ibgm.uva.es (M. Sánchez Crespo).

1 Equal contribution. responses seems to be of paramount importance since the large array of receptors involved in AC recognition and the list of mediators that can be produced by the distinct types of cells may vary broadly. Dendritic cells are characterized by their capacity to uptake microbial products and their ability to secrete the cytokines involved in the polarization of Th cells into Th1, Th2, and Th17 type responses. This is mainly achieved by the production of IL12 p70, IL-10, and IL-23, respectively, and depends on the nature of the stimuli. Combination of LPS and IFN- $\gamma$ is the most potent stimulus for IL-12 p70 production (Gautier et al., 2005), whereas zymosan, a cell wall extract of Saccharomyces cerevisiae, induces a response characterized by the production of IL-10 and IL-23, and a low amount of IL-12 p70 (Brown et al., 2003; Dillon et al., 2006; Leibundgut-Landmann et al., 2007). This effect of zymosan is particularly interesting because it contains PAMPs different from those found in LPS and is widely used as a surrogate for the study of the response to fungi because it mimics the composition of the cell wall of Candida, Aspergillus, and Pneumocystis spp. (Thomas and Limper, 2004) due to its high content in $\beta$-glucans and $\alpha$-mannans. In addition, mutations and polymorphisms in dectin-1, the receptor involved in $\beta$-glucan recognition have been associated with an increased risk for fungal infections (Ferwerda et al., 2009; Cunha et al., 2010). The rationale to study the immuno-modulating effect of AC on zymosan effect stems from several facts: (i) AC modulate 
the response to PAMPs and seem to play a role in the development of the compensatory anti-inflammatory response syndrome (CARS), where infection by fungi is frequently observed. (ii) Fungal patterns can bind receptors involved in the recognition of $A C$ (Chung et al., 2000; Zhou et al., 2001; Ziegenfuss et al., 2008; Means et al., 2009). (iii) Zymosan mimics some of the reported effects of AC since it is a good inducer of IL-10 and a week inducer of IL-12 p70.

The effect of AC on cytokine production has been associated with different mechanisms. On the one hand, about a dozen of receptors have been involved in the recognition of $\mathrm{AC}$, some of them requiring the cooperation of opsonins such as complement system components or bridging proteins as growth arrest-specific protein 6, protein S (Anderson et al., 2003), and milk fat globuleEGF factor 8 protein (Hanayama et al., 2002). The activation of those receptors induces a set of responses that ultimately impinge on the activation of different transcription factors, coactivators, and corepressors that regulate the transcription of cytokines. Among these transcription factors, NF- $\kappa$ B plays a central role in the production of IL-12 p70, TNF- $\alpha$, and several chemokines, whereas CREB is mainly involved in il10 transcriptional activation (Platzer et al., 1999; Martin et al., 2005; Hu et al., 2006; Ananieva et al., 2008; Alvarez et al., 2009; Kelly et al., 2010; Mellett et al., 2011). Transcription factors such as PPAR- $\gamma$ and LXR have been involved in the response to apoptotic cell burden, although in many cases they elicit indirect effects by acting as transrepressors (A-Gonzalez et al., 2009; Jennewein et al., 2008). The purpose of this study has been addressing the effect of $\mathrm{AC}$ on the production of the cytokines involved in the polarization of the immune response by human monocytederived dendritic cells (DC). We have observed an enhancement of IL-10 production by AC and a decrease of the amount of IL-23 elicited by the fungal surrogate zymosan. By contrast, the response to LPS and combination of LPS and IFN- $\gamma$ was unaffected. Attempts to address the role of complement factors and serum opsonins disclosed an enhancing effect of normal human serum (NHS) that persisted after heat inactivation, thus suggesting the involvement of opsonins and/or endogenous PPAR- $\gamma$ activators. Although exogenous $\mathrm{PGE}_{2}$ enhanced the effect of $\mathrm{AC}$, we did not find any evidence of the involvement of endogenous $\mathrm{PGE}_{2}$ nor formation of lipid bodies (LB). Since we consistently observed a transient nuclear translocation of the CREB coactivator CRTC2/TORC2 and the homeodomain protein PBX1, which is an element of the CREB/HOX/PBX/MEIS transcription complex that displays higher-order interactions with $\mathrm{CBP}$ and TORC coactivators, our data disclose a selective effect of AC on the production of IL-10 by the fungal surrogate zymosan that is best explained by an effect on CREB-dependent transcription.

\section{Materials and methods}

\subsection{Cells and materials}

Mononuclear cells were collected from buffy coats of healthy donors and differentiated into DC as reported (Valera et al., 2008). In short, adhered monocytes were incubated in the presence of GM-CSF and IL- 4 for 5 days, including the addition of fresh cytokines at day 2. Experiments were conducted without removing the medium, except in the experiments of arachidonic acid (AA) release, where the medium was replaced by delipidated BSA and in the experiments devoted to TGF- $\beta 1$ assay (see below). Macrophages were obtained from monocytes by culture for 14 days in medium supplemented with $10 \%$ heat-inactivated human serum. Ethical Committee approval was received for the studies and informed consent of all participating subjects was obtained. The experimental setting included culture in the presence of $10 \%$ FBS unless otherwise stated. Jurkat T cells were incubated with $10 \mu \mathrm{M}$ camptothecin for $5 \mathrm{~h}$ to induce apoptosis (Morris and Geller, 1996). AC were detected by Annexin V-FITC/PI staining (Becton Dickinson) and analyzed using a Gallios Flow Cytometer (Beckman Coulter). Viability of DC at the end of the experiments was confirmed by Annexin V-staining of cells expressing the mannose receptor. PMN were obtained by centrifugation on Ficoll-Hypaque and apoptosis was obtained by incubation at $37^{\circ} \mathrm{C}$ for $24 \mathrm{~h}$. Necrosis was induced by freeze-thawing. Zymosan, mannan from $S$. cerevisiae, and H89 were from Sigma Chemical Co. (St. Louis, MO). IL-12 p70 was assayed with reagents from Thermo Scientific Pierce (Rockford, IL) and IL-23 with reagents from R\&D systems (Minneapolis, MN). IL-10 was assayed with Biotrack ELISA systems from Amersham Biosciences. Bodipy ${ }^{\circledR}$ was from Invitrogen Ltd. (Paisley, UK). TGF$\beta 1$ was assayed with reagents from R\&D in conditioned medium where serum was substituted by BSA as per the manufacturer's instructions. In short, the cell medium containing $10 \%$ serum was substituted by medium containing $200 \mu \mathrm{g} / \mathrm{ml}$ crystalline BSA by several changes over $12 \mathrm{~h}$, and the conditioned medium containing BSA was treated by acidification and neutralization before the assay. Opsonization of zymosan was carried out by incubating in a shaking bath $10 \mathrm{mg}$ of boiled zymosan in $1 \mathrm{ml}$ of fresh human serum for $20 \mathrm{~min}$ at $37^{\circ} \mathrm{C}$. At the end of this period, zymosan particles were intensively washed in phosphate buffered saline to remove unbound materials.

\section{2. $\left[{ }^{3} H\right] A$ A release and $P G E_{2}$ assay}

Radioactive labeling of DC with $\left[{ }^{3} \mathrm{H}\right] \mathrm{AA}$ was performed by incubation of cells for $5 \mathrm{~h}$ in the presence of $0.25 \mu \mathrm{Ci} / \mathrm{ml}\left[{ }^{3} \mathrm{H}\right] \mathrm{AA}$ in $0.25 \%$ essentially fatty acid-free BSA (Fernández et al., 2003). After labeling, DC were washed with phosphate buffered saline and allowed to equilibrate at $37^{\circ} \mathrm{C}$ in medium containing $1 \% \mathrm{BSA}$ before the addition of stimuli or vehicle. The release of $\left[{ }^{3} \mathrm{H}\right] \mathrm{AA}$ into the culture medium was measured by scintillation counting and expressed as percent of total incorporated $\left[{ }^{3} \mathrm{H}\right] \mathrm{AA}$. $\mathrm{PGE}_{2}$ were assayed in $\mathrm{DC}$ supernatants with Biotrack ELISA systems (Amersham Biosciences) according to the manufacturer's instructions. The detection limit of the assay is $2.5 \mathrm{pg} / \mathrm{ml}$.

\subsection{Immunoblots}

Proteins were separated by electrophoresis in SDS/PAGE and transferred to nitrocellulose membranes. The membranes were used for immunodetection of COX-2 (sc-1745), CRTC2/TORC2 (sc46272), PPAR- $\gamma$ (sc-7196), and PBX1 (sc-889) with Ab from Santa Cruz Biotechnology Inc., Santa Cruz, CA. For immunoblots directed to assay nuclear proteins, the nuclear extracts were obtained using a nuclear extract kit (Active Motif, Carlsbad, CA). $\beta$-Actin and TBP were used as load control. Coimmunoprecipitation experiments were carried out using the Nuclear Complex Co-IP kit of Active Motif as reported (Alvarez et al., 2009).

\subsection{Assay of LB formation}

Cells stimulated under different conditions were incubated with $1 \mu \mathrm{M}$ Bodipy ${ }^{\circledR}$ for $30 \mathrm{~min}$ at $37^{\circ} \mathrm{C}$ and then fixed with $1 \%$ formaldehyde (Mattos et al., 2010). The induction of LB was measured at FL1 channel and was expressed as geometric mean fluorescence intensity (MFI). In the case of DC incubated with Jurkat AC, the analysis was conducted with two-color flow cytometric acquisition using anti-mannose receptor Ab to distinguish DC from Jurkat cells, which do not express this receptor. The analysis was performed on a Gallios Flow Cytometer using Kaluza software for quantitative data analysis. At least 10,000 cells were analyzed per sample. 


\subsection{Statistical analysis}

Results are expressed as mean \pm S.D. Data were analyzed by unpaired Student's $t$ test using GraphPad Prism version 4 (GraphPad Prism Software, San Diego, CA). Differences were considered statistically significant for a $p<0.05$.

\section{Results}

\subsection{Apoptotic Jurkat cells enhance zymosan-induced IL-10 production}

Treatment of Jurkat cells with camptothecin for $5 \mathrm{~h}$ induced a massive apoptosis as judged from the presence of more than $60 \%$ cells showing Annexin V-FITC staining, whereas only $\sim 6 \%$ cells showed positive staining for propidium iodide. When the incubation was prolonged up to $24 \mathrm{~h}$, the number of cells showing staining for both Annexin V-FITC and propidium iodide increased up to $\sim 55 \%$, thus indicating the occurrence of late apoptosis, whereas few cells were only stained with propidium iodide (Fig. 1A). Initial experiments were conducted adding $A C$ and proinflammatory stimuli simultaneously, but this produced results that were not reproducible. Since the only addition of AC did not elicit detectable production of cytokines, we interpreted that under these conditions the proinflammatory stimuli were the driving force and that the effect of $\mathrm{AC}$ was only modulatory. In keeping with these results, we have selected the sequence of early addition of $A C$ and then the most active stimuli. Incubation of DC with camptothecin-treated
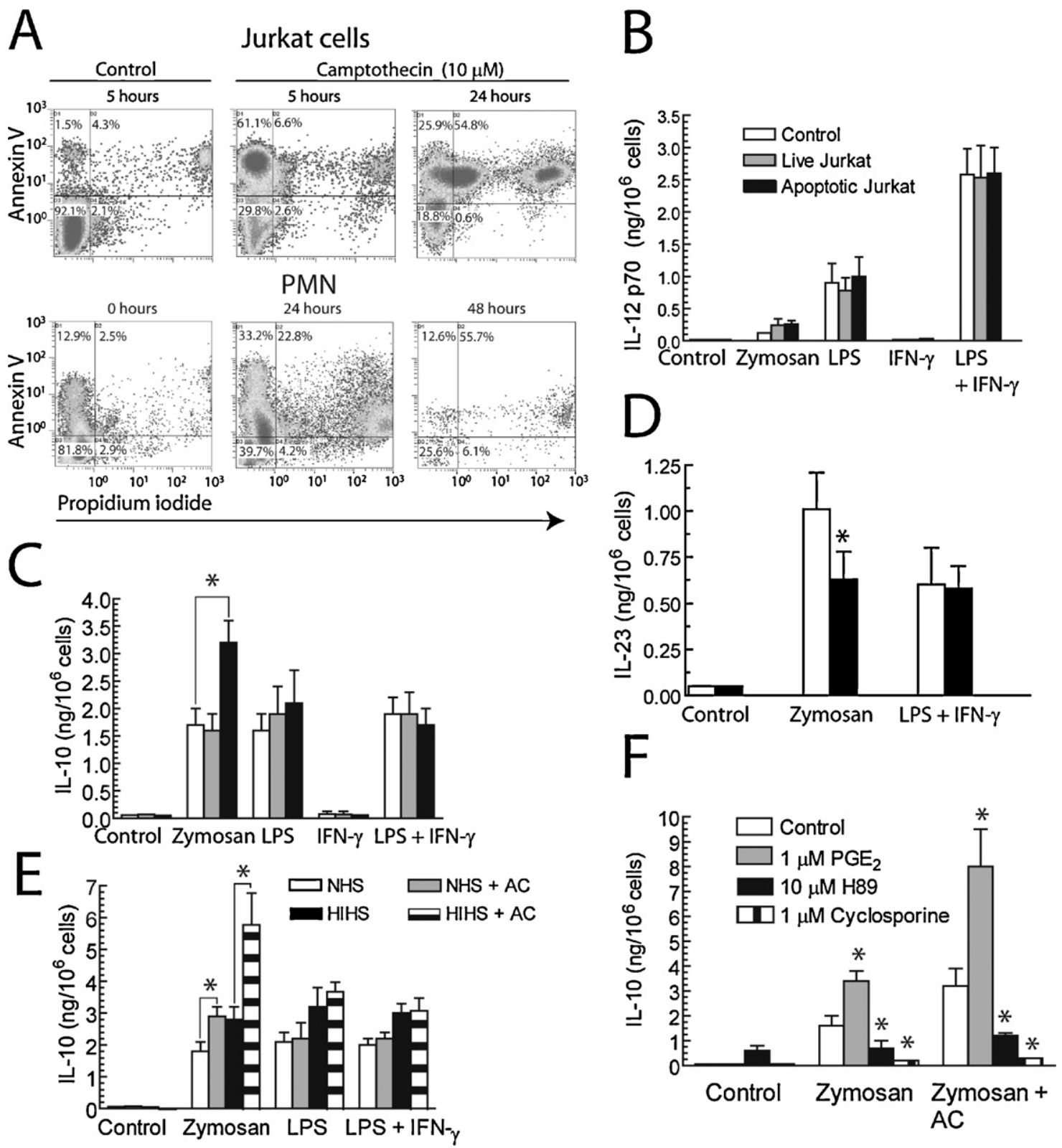

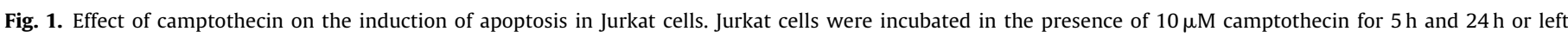

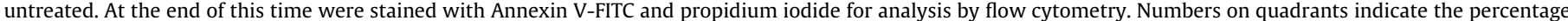

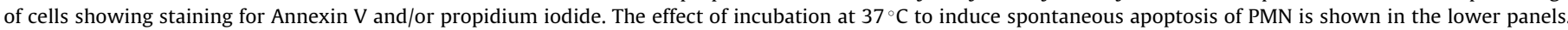

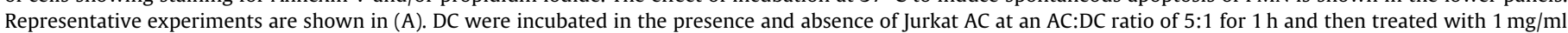

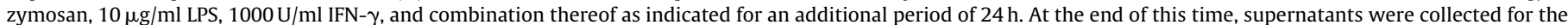

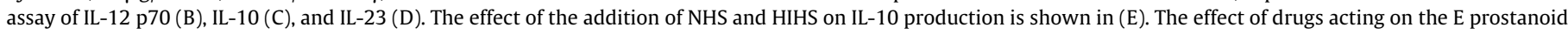
receptor/PKA/CREB system is shown in (F). Results represent mean \pm S.D. of 5-8 experiments; * $p<0.05$. 
Jurkat cells for $1 \mathrm{~h}$ before the addition of stimuli acting on TLR and C-type lectin receptors, and/or IFN- $\gamma$ did not significantly influence the production of IL-12 p70 (Fig. 1B). In contrast, AC increased the production of IL-10 and significantly reduced IL-23 production in response to zymosan, whereas the effect of both LPS and combination of LPS and IFN- $\gamma$ was not modified (Fig. 1C and D). These data differ from studies carried out in macrophages where the increase of IL-10 induced by AC is mirrored by a decrease of IL-12 p70 (Kim et al., 2004; A-Gonzalez et al., 2009; Mukundan et al., 2009), whereas to the best of our knowledge, there are no reports on IL-23 production. Since opsonization of apoptotic cells by $\mathrm{iC} 3 \mathrm{~b}, \mathrm{a}$ proteolysis product of the complement cleavage fragment $\mathrm{C} 3 \mathrm{~b}$, has been found to mediate a distinct anti-inflammatory response and NF-кB blockade (Behrens et al., 2007, 2008), experiments were conducted supplementing the medium with NHS as a source of active complement and heat-inactivated human serum (HIHS) as a putative source of other opsonins. As shown in Fig. 1E, the effect of HIHS was more robust than the effect of NHS, thus suggesting that opsonins other than $\mathrm{iC} 3 \mathrm{~b}$ and/or endogenous stimuli are involved in the signaling mechanism that enhances IL-10 production. Again, AC failed to influence significantly the amount of IL-10 released by LPS and combination of LPS and IFN- $\gamma$ in the presence of NHS. Since TGF- $\beta 1$ has been associated with the immune tolerance associated with AC uptake, this cytokine was measured in the supernatants of DC stimulated with different additions in the absence of serum to overcome the interference that could be due to the presence of latent TGF- $\beta 1$. Incubation with opsonized zymosan for $24 \mathrm{~h}$ induced the production of $0.1 \mathrm{ng} / \mathrm{ml}$ TGF- $\beta 1$, whereas AC, LPS, and zymosan failed to elicit TGF- $\beta 1$, what is a significant difference with the results observed in macrophages, where AC, LPS, and zymosan induced the production of TGF- $\beta 1$ (Fig. $2 \mathrm{~A}$ ). In line with the different behaviors of these cell populations, IL-10 production was observed in macrophages under these conditions, although to a lower than in DC (Fig. 2B).

Since IL-10 production in DC mostly depends on CREBdependent transcription and this can be modulated by different pharmacological treatments, we went on to address the effect of $\mathrm{PGE}_{2}$, the kinase inhibitor $\mathrm{H} 89$, and the calcineurin inhibitor cyclosporine A. As shown in Fig. 1F, $\mathrm{PGE}_{2}$ increased the production of IL-10 elicited by zymosan and this was more evident in the presence of AC. The protein kinase A and mitogen- and stresskinase inhibitor $\mathrm{H} 89$ significantly inhibited IL-10 production in the presence of $A C$, which agrees with previous findings on the involvement of CREB-dependent transcription on the regulation of il10 (Ananieva et al., 2008; Alvarez et al., 2009), and cyclosporine A completely inhibited the response. Since cyclosporine A can modulate IL-10 production via calcineurin-dependent regulation of the CREB coactivator CRTC2/TORC2 (Kovács et al., 2007; Jansson et al., 2008), these results are consistent with the involvement of CREBdependent transcription in the regulation of IL-10 expression. We next assessed the effect of $A C$ on the nuclear translocation of CRTC2/TORC2 since this CREB coactivator has been found to regulate the production of IL-10 elicited by zymosan (Alvarez et al., 2009). In keeping with this notion, preincubation of AC with DC induced a transient translocation of CRTC2/TORC2 to the nucleus that could be observed between 30 and 45 min after addition of the AC (Fig. 3A and B), whereas incubation of AC with zymosan did not induce the nuclear translocation of CRTC2/TORC2 (Fig. 3A lower panels). The transient nature of CRTC2/TORC2 translocation can be explained by the complex molecular mechanism involved in its activation/deactivation that includes dephosphorylation activation, acetylation by $\mathrm{CBP} / \mathrm{p} 300$, deacetylation by sirt1, ubiquitylation by a nuclear E3 ligase, and targeting for proteasomal degradation (Liu et al., 2008).

Since CRTC2/TORC has been found in large complexes containing the transcription factor CREB and the homeodomain protein
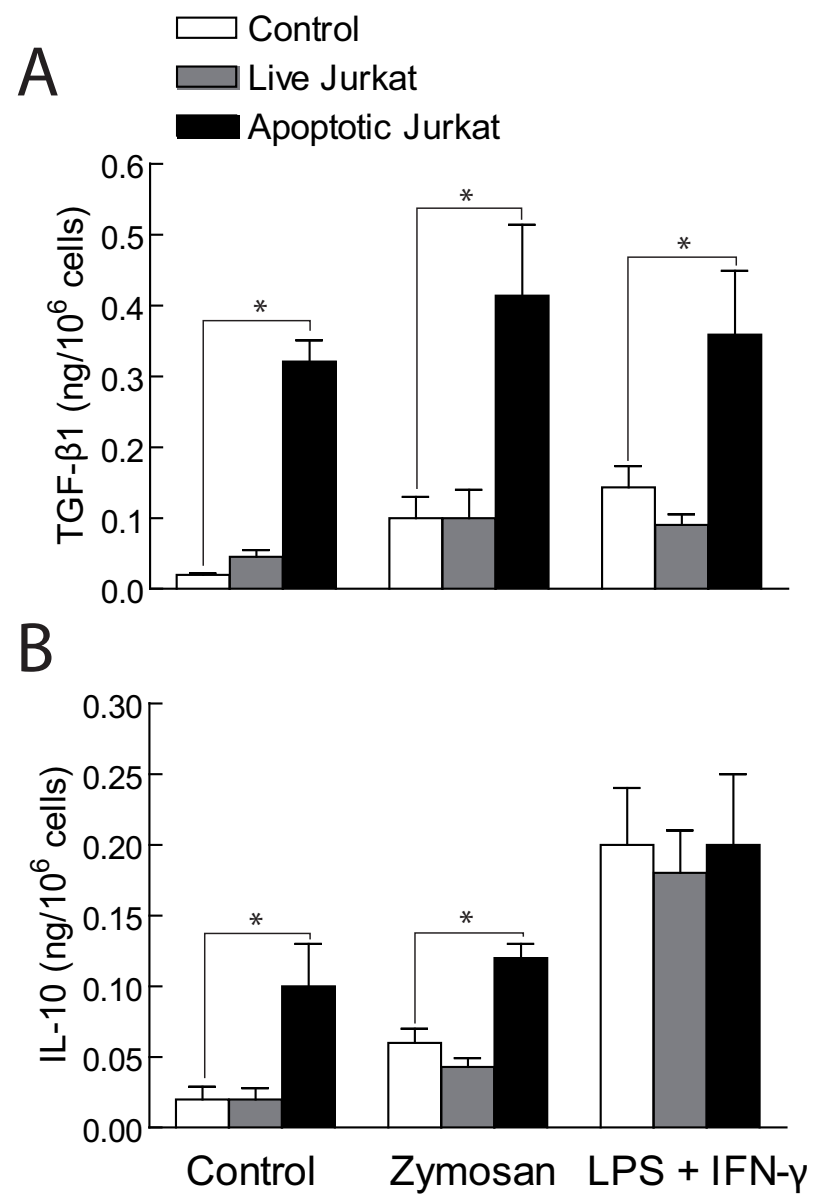

Fig. 2. Production of TGF- $\beta 1$ and IL- 10 by monocyte-derived macrophages. Monocytes differentiated into macrophages by culture for 14 days in the presence of HIHS were stimulated with different stimuli for $24 \mathrm{~h}$ at the concentrations indicated in the legend to Fig. 1, in the presence and absence of live and apoptotic Jurkat cells. At the end of this period, the cytokines were assayed in the supernatants. Results represent mean \pm S.D. of 4 experiments; ${ }^{*} p<0.05$ as compared to control macrophages incubated in the absence of Jurkat cells.

PBX1, previously reported to be involved in the regulation of IL-10 production by macrophages in response to AC load (Chung et al., 2007), we addressed whether CRTC2/TORC2 nuclear translocation was associated with PBX1. In line with this notion, incubation of DC with AC for 45 min induced an increased expression and the nuclear translocation of $\mathrm{PBX} 1$, thus paralleling the time-frame of CRTC2/TORC2 nuclear translocation, although to a lower extent than zymosan (Fig. 3C). This might suggest that the response elicited by AC is not potent enough to elicit IL-10 production and that its effect is only observed in the presence of an additional stimulus. Consistent with the involvement of common routes of signaling for AC and zymosan, co-stimulation with AC and zymosan increased the translocation of CRTC2/TORC2 and PBX1 observed with single stimulus (Fig. 3D). Notably, coimmunoprecipitation of PBX1 with CRTC2/TORC2 was observed in DC incubated with AC (Fig. 3E), as well as coimmunoprecipitation of CRTC2/TORC2 and PBX1 with P-CREB (Fig. 3F).

As regards the normalization for protein load in these experiments, it should be pointed out that the lanes loaded with samples of DC incubated with AC show a small increase of the $\beta$-actin load, whereas they show a high increase of the amount of the nuclear protein TBP. A likely explanation for this fact could be that Jurkat cells are endowed with a small cytoplasm, whereas DC and macrophages show a large cytoplasm in keeping with their ability to uptake and process a large number of particles. 


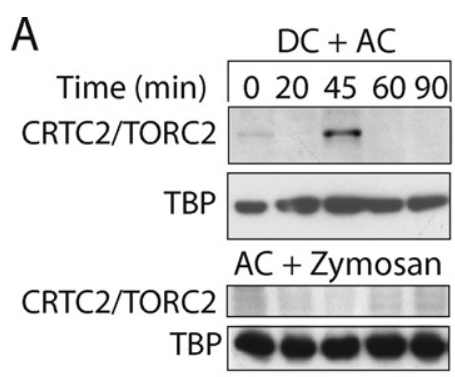

C

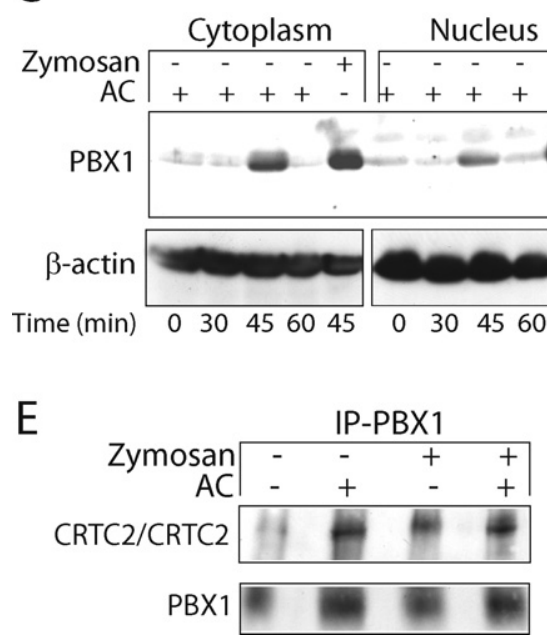

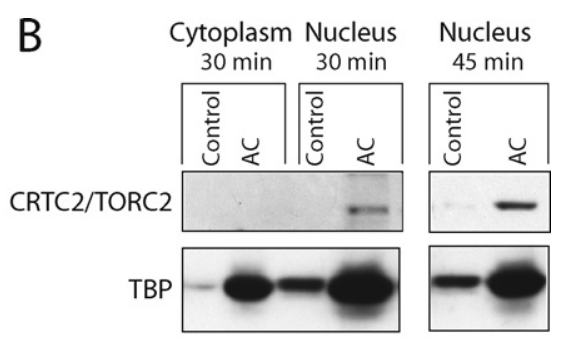

D

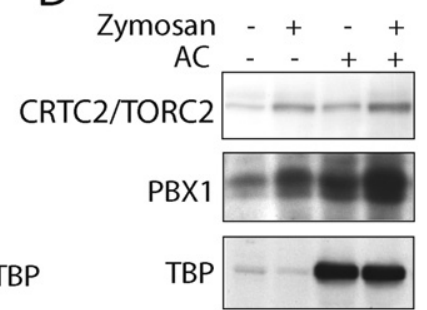

$\mathrm{F}$

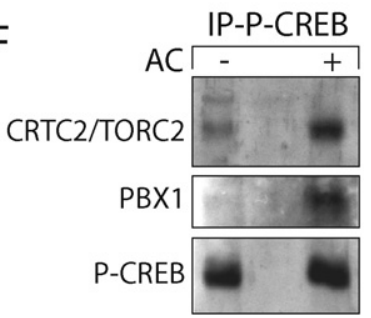

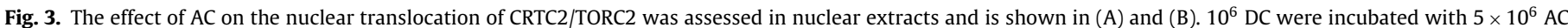

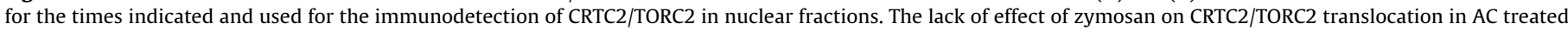

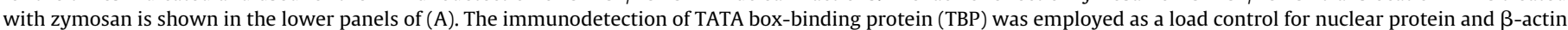

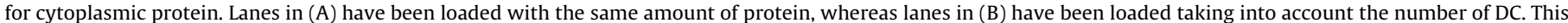

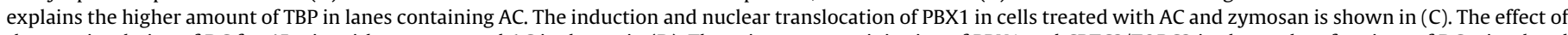

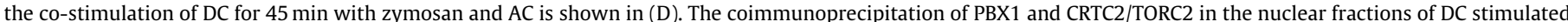

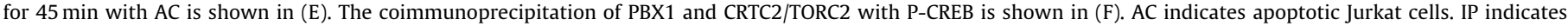
immunoprecipitation.

\subsection{Possible involvement of COX-2 and $L B$}

Exogenous $\mathrm{PGE}_{2}$ is a synergistic enhancer of IL-10 production (Harizi et al., 2002) as well as an autocrine effector of IL-10 production in response to zymosan (Alvarez et al., 2009) and a strong activator of the E prostanoid/PKA/cyclic AMP/CREB route. Moreover, $\mathrm{PGE}_{2}$ generation has also been reported during the uptake of AC by macrophages (Fadok et al., 1998; Medeiros et al., 2009). On this basis, we addressed the possible involvement of eicosanoids by looking at the release of AA and the induction of COX-2. As shown in Fig. 4A, AC failed to induce the release of $\left[{ }^{3} \mathrm{H}\right] \mathrm{AA}$ from $D C$, whereas these cells responded to stimuli of pathophysiological relevance such as zymosan, complement-coated zymosan, and IgG-coated zymosan. Since $\mathrm{PGE}_{2}$ production may depend not only on a rapid release of AA from membrane phospholipids, but also on a more delayed process involving induction of COX-2 and oxidation of AA generated in the constitutive deacylation-reacylation cycle, we assessed the effect of $A C$ on $\mathrm{COX}-2$ protein induction. As shown in Figs. 4B and 5, AC did not significantly enhance the expression of COX-2 in DC and macrophages, nor did they enhance the effect of stimuli such as zymosan, mannan, and LPS. Moreover, when the effect of live and necrotic cells was tested in parallel, AC rather inhibited the expression of COX-2 elicited by the pro-inflammatory stimuli when the amount of COX-2 protein was normalized taking into account the number of DC (Fig. 4B). Since COX-2 protein contains a C-terminal 19-aa instability sequence (Mbonye et al., 2008), a plausible explanation for the multiple bands observed in some experiments could be the presence of break down products.
To address whether the observed effect was restricted to Jurkat cells or whether it is shared by other cell types, experiments were carried out with PMN. As shown in Fig. 5D, PMN maintained at $37^{\circ} \mathrm{C}$ to undergo spontaneous apoptosis also reduced the expression of COX-2 elicited by zymosan. In line with the absence of enhancement of COX-2 protein expression under these conditions, AC did not induce $\mathrm{PGE}_{2}$ production, nor did they enhance the amount of $\mathrm{PGE}_{2}$ produced in response to both LPS and zymosan (Fig. 5E). In fact, a reduction of $\mathrm{PGE}_{2}$ was observed that can be related to either reduction of COX-2 protein expression and/or non-specific trapping of $\mathrm{PGE}_{2}$ in the $\mathrm{AC}$ membranes.

Recent studies have disclosed the ability of phagocytes to accumulate lipids in response to infection in nonmembrane-bound cytoplasmic organelles known as LB that can be stained with Bodipy $^{\circledR}$. The formation of LB depends on the activation of TLR (Pacheco et al., 2002) and PPAR- $\gamma$ (de Assis et al., 2003). In addition, COX-2 accumulates in the LB and these are a major platform for eicosanoid biosynthesis. Incubation of DC with Jurkat AC did not modify the MFI of Bodipy ${ }^{\circledR}$-labeled DC, since the MFI was comparable in cells incubated in the presence and absence of Jurkat AC as judged from the result of data analysis with Kaluza software (data not shown). Zymosan increased Bodipy ${ }^{\circledR}$-labeling of DC both in the presence and in the absence of $A C$, but this was considered as a result of non-specific uptake of Bodipy ${ }^{\circledR}$ by zymosan particles (data not shown). Further analysis of this issue was conducted by antagonizing PPAR- $\gamma$ with GW9662 (Huang et al., 1999; Willson et al., 2000). Bodipy ${ }^{\circledR}$ labeling showed the same MFI in the presence and absence of GW9662, both in DC treated with zymosan and in cells 


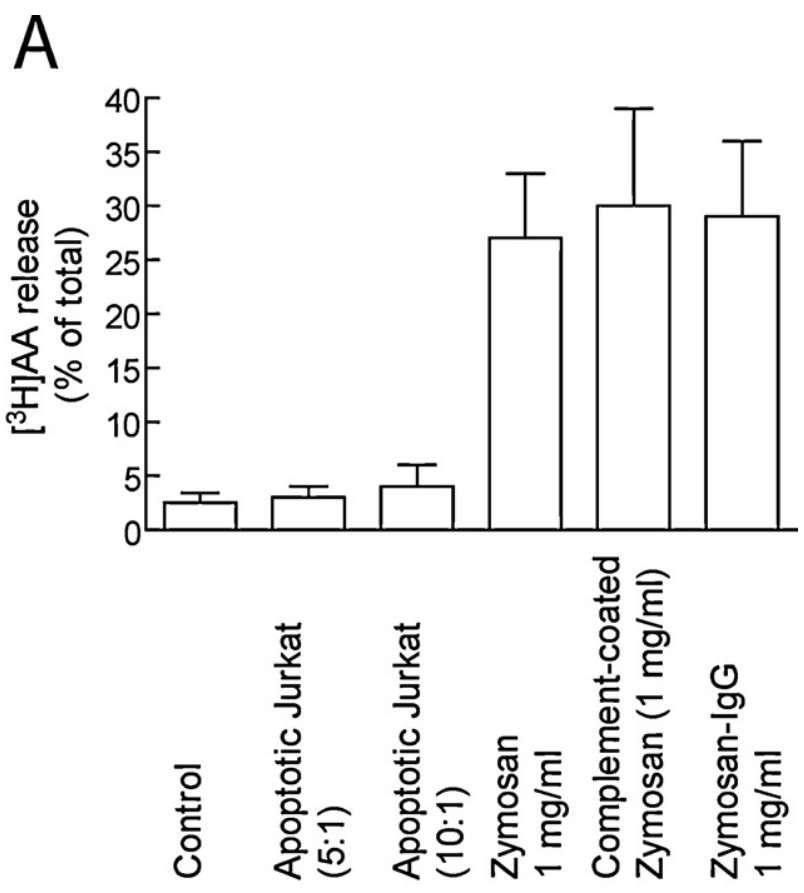

B

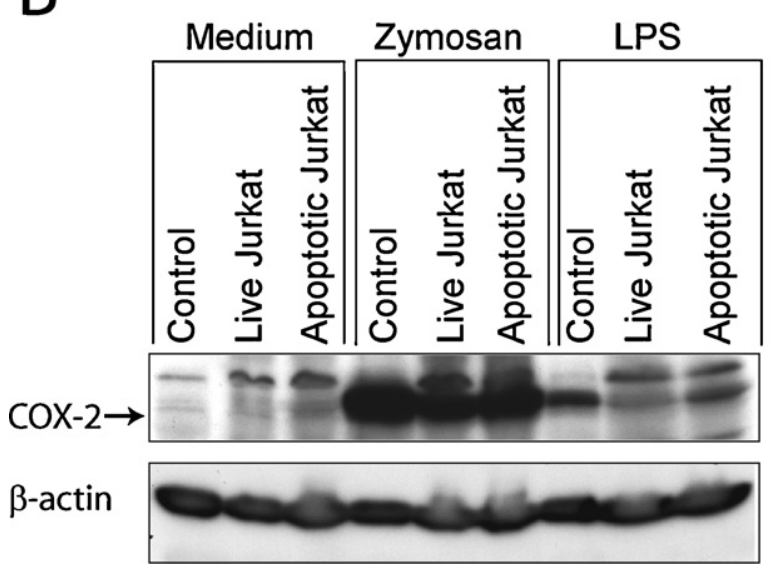

Fig. 4. Effect of AC on the release of $\left[{ }^{3} \mathrm{H}\right] \mathrm{AA}$. DC labeled with $\left[{ }^{3} \mathrm{H}\right] \mathrm{AA}$ were stimulated for $1 \mathrm{~h}$ as indicated. At the end of this period, $\left[{ }^{3} \mathrm{H}\right] \mathrm{AA}$ radioactivity was assayed in both supernatants and cell pellets. $\left[{ }^{3} \mathrm{H}\right] \mathrm{AA}$ release is expressed as percentage of total $\left[{ }^{3} \mathrm{H}\right] \mathrm{AA}$ incorporated into cell phospholipids. Results represent mean \pm S.D. of 4 experiments (A). Effect of the incubation of DC with live and AC on COX-2 induction. Samples were loaded into the gel lanes according to the number of DC. Note that the $\beta$-actin load in the different lanes shows little difference between control and Jurkat cell containing lanes despite the absence of AC in the control lanes. In contrast, when the load control was conducted on the basis of nuclear protein content as in Fig. 3B and C, a higher amount of TBP was detected, most likely reflecting a higher proportion of nuclear proteins over cytoplasmic proteins in Jurkat cells (B).

treated with zymosan and Jurkat AC (data not shown), thus indicating that a treatment that blocks LB formation in macrophages does not reduce Bodipy ${ }^{\circledR}$ MFI and that zymosan may interfere in the analysis by interacting with Bodipy ${ }^{\circledR}$. Further assessment of the involvement of PPAR- $\gamma$ was conducted by assaying its protein expression. Since PPAR- $\gamma$ induction in DC has been found to be strongly dependent on the presence of either exogenous or endogenous activators and NHS contains endogenous activators (Szatmari et al., 2007), experiments were conducted in the presence of both fetal bovine serum (FBS) and NHS. As shown in Fig. 6A, PPAR- $\gamma$ expression was only observed in DC incubated with 10\% NHS irrespective of whether it had been heat inactivated or not. Notably, although zymosan did not induce PPAR- $\gamma$ expression in the absence
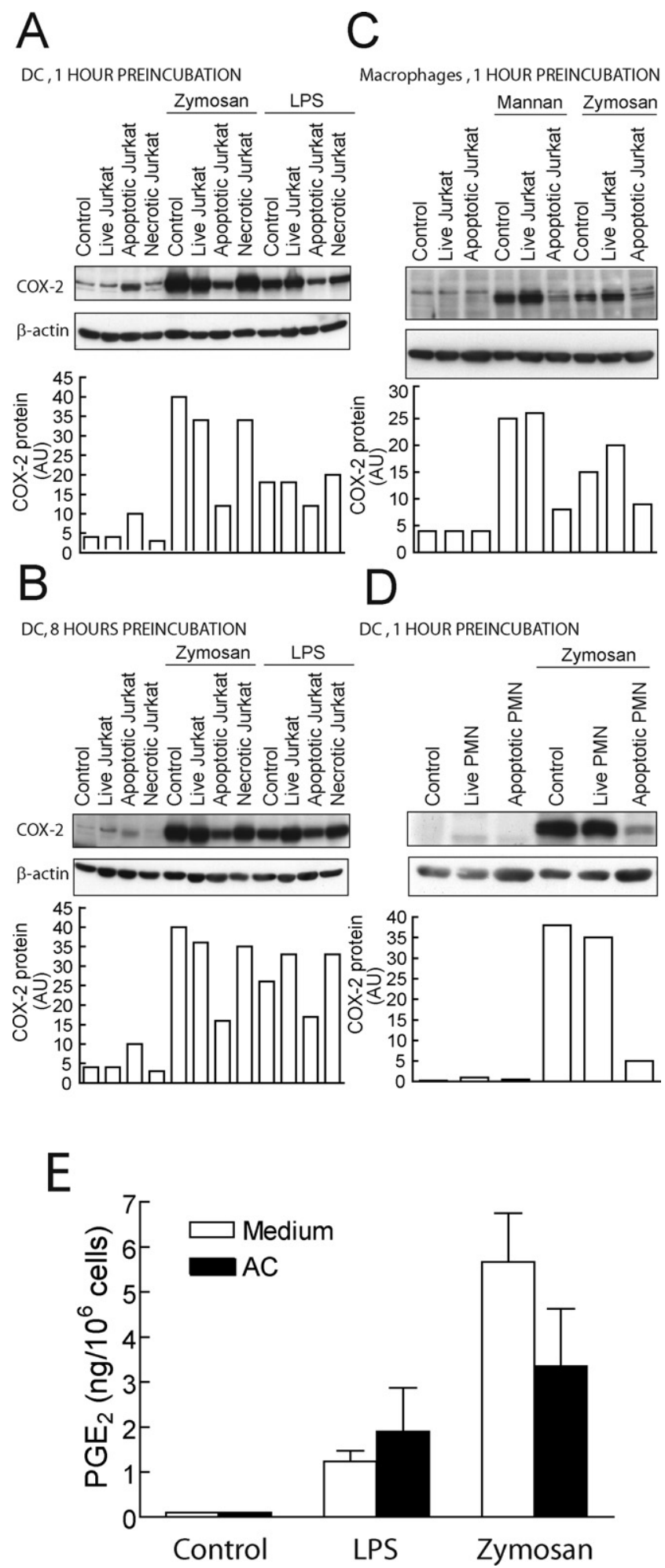

Fig. 5. Effect of AC on the induction of COX-2 elicited by different stimuli. DC were incubated with live Jurkat cells, AC, or necrotic Jurkat cells for $1 \mathrm{~h}$ or $8 \mathrm{~h}$, as indicated, and then stimulated with different additions for $12 \mathrm{~h}$. At the end of this period, cell lysates were collected for the assay of COX-2 protein expression (A and B). The experiment shown in $(C)$ was conducted with adhered macrophages. The experiment shown in (D) was conducted with PMN instead of Jurkat AC. $\beta$-Actin expression was used as a load control. The production of $\mathrm{PGE}_{2}$ was assayed in the supernatants of DC treated with different stimuli in the presence and absence of AC. Results represent mean \pm S.D. of 6 experiments (E). 

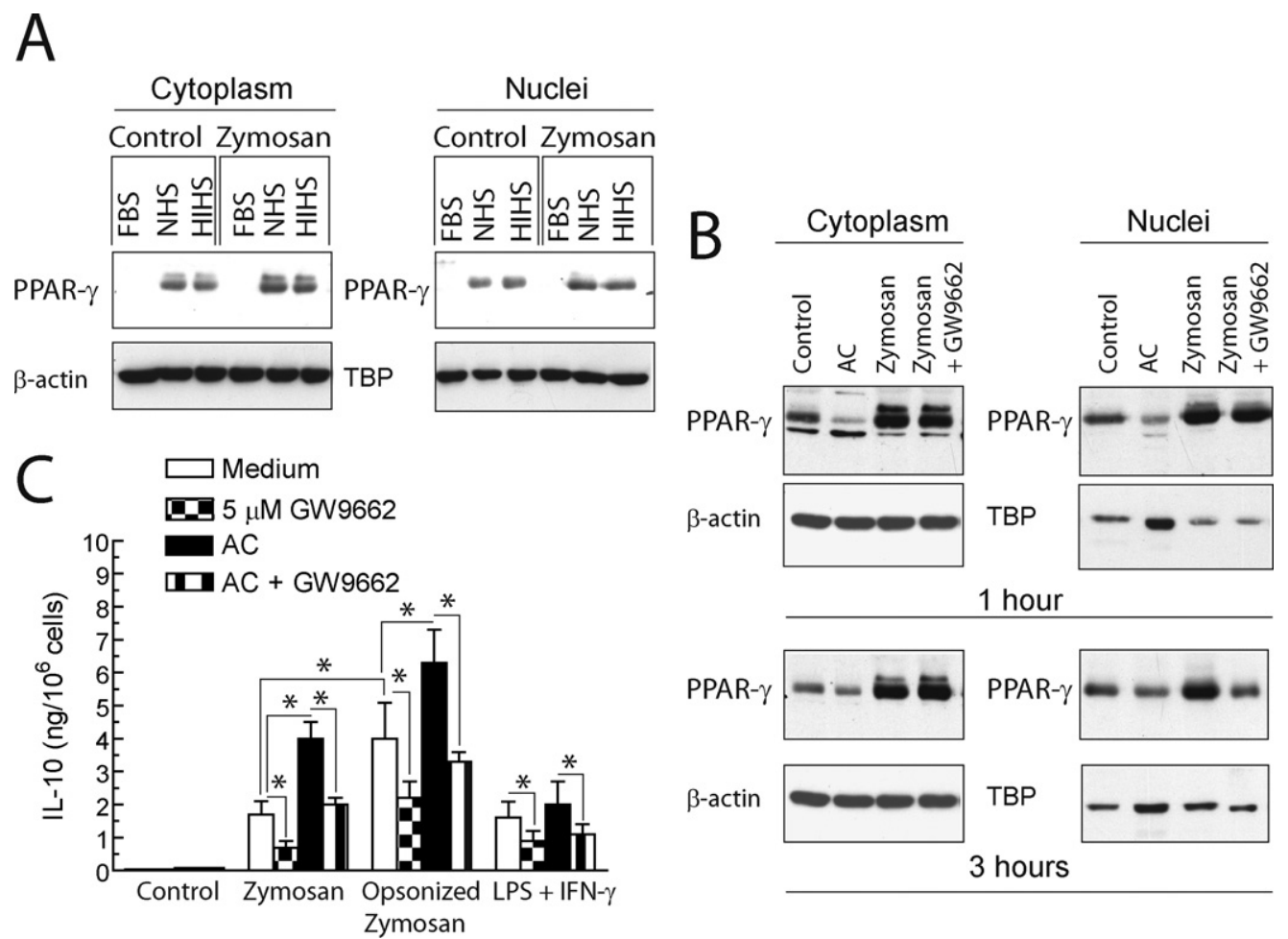

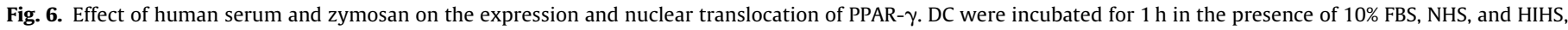

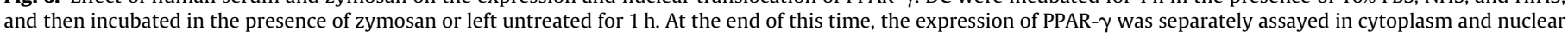

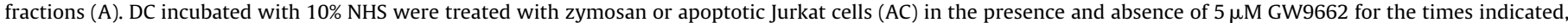

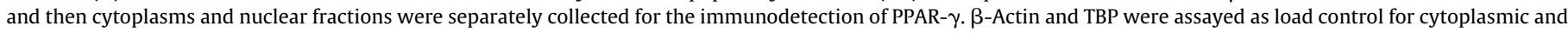

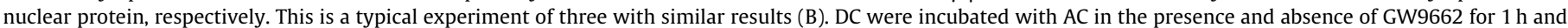

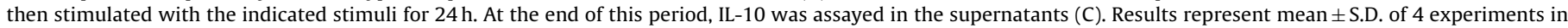

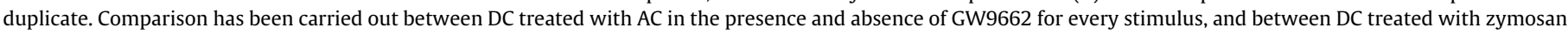
and opsonized zymosan in the absence of further addition; ${ }^{*} p<0.05$.

of NHS, it enhanced the effect of NHS for at least $3 \mathrm{~h}$ (Fig. 6B). $5 \mu \mathrm{M}$ GW9662 blunted significantly PPAR- $\gamma$ nuclear translocation at $3 \mathrm{~h}$, but not at $1 \mathrm{~h}$. When GW9662 was used to modulate IL-10 production, this treatment reduced the production of IL-10 both in the presence and in the absence of AC and when combination of LPS and IFN- $\gamma$ was used as a stimulus. When serum-opsonized zymosan was used as a stimulus, the production of IL-10 was enhanced as compared with that observed with non-opsonized particles and was also sensitive to GW9662 treatment (Fig. 6C), thus suggesting that PPAR- $\gamma$ inhibition produces the same effect when complement receptors as CR3 ( $\alpha_{M} \beta_{2}$-integrin) are engaged in addition to the $\beta$-glucan receptor dectin- 1 . Taken collectively, these data indicate that although zymosan enhances PPAR- $\gamma$ induction and nuclear translocation, specially in the presence of NHS, PPAR- $\gamma$ activation on its own does not induce LB formation, although it might contribute to the enhancement of IL-10 production elicited by AC in the presence of different stimuli. However, the possibility that GW9662 might exert PPAR- $\gamma$-independent effects cannot be ruled out.

\section{Discussion}

The present results confirm previous studies on the modulation of IL-10 production by AC and provide new mechanistic insight suggesting cell- and stimulus-specific routes of cross-talk. In line with this, the study focuses on DC since most reports have been conducted in macrophages. An unexpected finding has been the observation that AC on their own do not elicit the production of IL-10 by DC even at very high AC:DC ratio (30:1, data not shown). In addition, we have not been able to show the production of TGF- $\beta 1$ in response to $A C$ under conditions where the contribution of latent TGF- $\beta 1$ from serum could be ruled out. An explanation for this result consistent with our findings could be that the production TGF- $\beta 1$ by $A C$ is a response involving macrophages and plasmacytoid DC rather than monocyte-derived DC (Bonnefoy et al., 2011). The effect of the AC was only exerted when DC were stimulated with zymosan, a stimulus characterized by its ability to induce IL23 expression rather than IL-12 p70. In contrast, AC do not influence the production of IL-12 p70 by the stimuli most suitable for eliciting optimal IL-12 p70 production such as combination of LPS and IFN$\gamma$. The selection of the concentrations and combinations of stimuli stems from previous studies. In fact, IL-12 p70 production by DC stimulated with LPS was not saturated with concentrations as high as $20 \mu \mathrm{g} / \mathrm{ml}$ (Alvarez et al., 2011). This can be explained because the process of differentiation of monocytes into DC is associated with a decrease of the surface display of CD14 and also with the notion that optimal production in response to LPS may depend on the concomitant presence of signals elicited by other agonists, for instance IFNs (Gautier et al., 2005; Snijders et al., 1998). In addition, recent reports stressed that ultrapure LPS does not consistently induce detectable quantities of IL-12 p70 and IL-23 from human DC (Napolitani et al., 2005; Goodall et al., 2010). As regards zymosan, optimal production of IL-23 is obtained with concentrations higher than $0.2 \mathrm{mg} / \mathrm{ml}$ and different dose-response patterns can be observed for each cytokine (Gerosa et al., 2008). In view of the variations on the surface display of receptors that can exist between macrophages and DC, and even between the different types of macrophages and DC, it seems possible that the effect of AC on monocyte-derived DC observed in this study cannot be straightforwardly extended to other types of DC. 
Our findings are reminiscent of recent reports disclosing the existence of shared mechanisms of uptake of and signaling to AC and fungal components. For instance, it has been reported that human dectin-1 binds to AC, facilitates their uptake by DC, and mediates cross-presentation of cell-derived antigens (Weck et al., 2008). A recent study has disclosed that necrotic cells bind the C-type lectin receptor CLEC9A and trigger signaling in a Sykdependent fashion (Sancho et al., 2009). Draper is a Drosophila receptor ortholog of CED-1 from Caenorhabditis elegans (Chung et al., 2000) that is essential for the uptake of AC (Zhou et al., 2001) and binds Shark, a Drosophila tyrosine kinase similar to Syk (Ziegenfuss et al., 2008) via an ITAM motif. The mammalian orthologs of CED-1, SCARF1 and CD36 are $\beta$-glucan receptors that contribute to the defense against fungi and like CED-1 can engulf cell corpses (Means et al., 2009). Notably, CD36 has been shown to display a strong capacity to promote the uptake of $A C$ and to elicit IL-10 production by a mechanism involving CD36-dependent tyrosine phosphorylation of PREP-1, a dimerizing partner of PBX1 and MEIS (Chung et al., 2007). Altogether, these data stress the similarities between Draper/Src42A/Shark signaling in C. elegans, and C-lectin receptor/Syk signaling in the immune system of mammalians (Zhou et al., 2001).

The down-regulation of the production of IL-23 by zymosan elicited by $\mathrm{AC}$ can be a direct consequence of the IL-23 polarizing effect of zymosan. Whereas the induction of IL-12 p35 transcription by zymosan is very low and zymosan even blunts the transcription elicited by other stimuli (Dennehy et al., 2009; Huang et al., 2009; Alvarez et al., 2011), zymosan induces a detectable expression of IL$12 \mathrm{p} 40$ that is almost exclusively used for IL-23 production. On this basis, the effect of AC on IL-23 production might reflect an effect on IL-12 p40 transcription.

Although it remains unclear the mechanism underlying the effect of AC on IL-10 production, it seems likely that it could be explained via CREB-dependent transcription, since CREB plays a central role in the transcriptional regulation of $i l 10$ by forming a complex that at least includes the coactivators CRTC2/TORC2 and CBP. Notably, it has been described in several systems the association of the aforementioned complex with the homeodomain proteins MEIS1, HOX, and PBX1 (Tohyama and Yamamura, 2009), as well as the dependence of MEIS1 interaction with TORC on PKAmediated phosphorylation reactions (Goh et al., 2009; Wang et al., 2010). This mechanism of transcriptional control based on the formation of a multisubunit complex is consistent with our finding of a transient nuclear translocation of CRTC2/TORC2 and PBX1 in response to $A C$ and the synergistic effect of $\mathrm{PGE}_{2}$ on IL-10 production, since $\mathrm{PGE}_{2}$ is a well-known elevator of the intracellular concentration of cyclic AMP and of PKA-dependent signals. Because the aforementioned dependence of il10 transcriptional regulation on the homeodomain proteins PBX1 and PREP-1 in response to AC is not shared by stimuli like LPS (Chung et al., 2007), our findings provide further support to the parallelism of the signaling routes elicited by $A C$ and $\beta$-glucans.

$A$ factor that enhances the recognition of $A C$ is the presence of opsonins that favor bridging of $A C$ to receptors expressed on the phagocyte membrane. In this connection, complement-dependent opsonization of AC has been found to produce a distinct antiinflammatory response characterized by a modest increase of IL-10 production and an inhibition of NF- $\kappa \mathrm{B}$ activation (Amarilyo et al., 2010). Although our study does not focus on the role of complement factors, our data indicate that the effect of AC on IL-10 production does not require an intact complement system, since HIHS produced even higher induction of IL-10 than NHS. An explanation for this finding could be the activation of PPAR- $\gamma$ by serum factors, since it has been reported that PPAR- $\gamma$-dependent transcription in DC is activated to a similar extent by exogenous ligands of PPAR- $\gamma$ and by NHS (Szatmari et al., 2007; Szatmari and Nagy,
2008), thus suggesting that NHS contains PPAR- $\gamma$ activators or ligand precursors. Since our data have shown a clear induction of PPAR- $\gamma$ by zymosan and a reduction of IL-10 production upon PPAR- $\gamma$ inhibition, our results are consistent with a modulatory effect of PPAR- $\gamma$ on IL-10 production, specially in the presence of NHS. Since PPAR- $\gamma$ may not be directly involved in il10 transcription, a likely explanation could be that PPAR- $\gamma$ might indirectly modulate IL-10 production by inhibiting NF- $\kappa$ B activity. This inhibition would allow a more efficient CREB-dependent transcription by making it available a higher disposal of CBP for CREB interaction (Vo and Goodman, 2001). A recent report has shed light on the role of PPAR- $\gamma$ in macrophages and DC by showing a strong dependence of PPAR- $\gamma$-mediated gene expression on the activity of STAT6 induced by IL-4 signaling, thus positioning PPAR- $\gamma$ downstream of IL-4 in the alternative macrophage activation cascade. In contrast, the IL4 transcriptome was modestly affected in the absence of the gene encoding PPAR- $\gamma$ (Szanto et al., 2010). Since IL-4 is necessary for the differentiation of human monocytes into DC, these findings suggest a discrete role for PPAR- $\gamma$ signaling on its own in the transcriptional program for handling lipids after phagocytosis of AC or parasites (Villanueva and Tontonoz, 2010), and agree with recent studies suggesting a more relevant role for the related nuclear receptor PPAR- $\delta$ in phagocytic responses (Mukundan et al., 2009).

The prominent enhancement of IL-10 production by $\mathrm{PGE}_{2}$ is in keeping with earlier studies showing cooperation of $\mathrm{PGE}_{2}$ with other stimuli to induce IL-10 and could agree with the reported role of $\mathrm{PGE}_{2}$ in the mediation of the response to $\mathrm{AC}$. However, our data are less conclusive about the involvement of $\mathrm{PGE}_{2}$ in the mediation of AC effect in DC, since we have not been able to disclose AA release nor $\mathrm{PGE}_{2}$ production by $\mathrm{AC}$ nor induction of COX-2. Rather, we have observed a tendency of $A C$ to reduce the induction of COX-2 protein elicited by zymosan and mannan. The formation of LB by different types of leukocytes has been considered of central importance in the production of $\mathrm{PGE}_{2}$ in response to TLR ligands in macrophages (Pacheco et al., 2002). Since zymosan is a ligand of TLR2 (Gantner et al., 2003; Brown et al., 2003) and $\beta$-glucans from Histoplasma capsulatum cell wall have been found to induce LB formation (Sorgi et al., 2009), we hypothesized that the effect of AC and zymosan on IL-10 could be related to LB formation and $\mathrm{PGE}_{2}$ production. However, our findings do not support the formation of LB in DC in response to zymosan and AC. One explanation for this finding could be that the formation of LB is cell-specific and is preferentially observed in granulocytes and macrophages rather than in DC (Bozza et al., 2009). Another reason could be that LB formation might be restricted to microbes showing limited virulence. For instance, infection of macrophages by the virulent Mycobacterium tuberculosis strain H37Rv actively inhibits $\mathrm{PGE}_{2}$ production, whereas macrophages infected by the avirulent H37Ra strain produce high amounts of $\mathrm{PGE}_{2}$ (Chen et al., 2008). Moreover, activation of PPAR- $\gamma$ in DC has been associated with a reduction of LB (Szatmari et al., 2007), most likely explained as a consequence of an enhanced capacity to metabolize/redistribute lipids that may result in diminished cytoplasmic lipid content. In summary, our data show an enhancement by AC of the production of IL-10 elicited by zymosan in DC, associated with the nuclear translocation of the CREB coactivator CRTC2/TORC2 and the homeodomain protein PBX1. This was accompanied by a reduction of IL-23 production. The production of IL-10 was enhanced by exogenous $\mathrm{PGE}_{2}$, both in the presence and in the absence of AC, and was sensitive to PPAR$\gamma$ inhibition. Taken collectively these data indicate that AC may directly influence the polarization of the immune response to fungal products by enhancing IL-10 and inhibiting IL-23 production, whereas they do not necessary do so through inhibition of IL-12 p70 production. In keeping with this notion, it has recently been reported that after contact with AC, DC do release IL-12 p70 upon exposure to CD40-ligand (Johansson et al., 2010). 


\section{Acknowledgments}

Staff from Centro de Hemoterapia y Hemodonación de Castilla $y$ León is thanked for help with blood cell purification. This work was supported by Plan Nacional de Salud y Farmacia (grants SAF2007-60446 \& SAF2010-15070), Fundación Ramón Areces, and Red Temática de Investigación Cardiovascular.

\section{References}

A-Gonzalez, N., Bensinger, S.J., Hong, C., Beceiro, S., Bradley, M.N., Zelcer, N., Deniz, J., Ramirez, C., Díaz, M., Gallardo, G., de Galarreta, C.R., Salazar, J., Lopez, F., Edwards, P., Parks, J., Andujar, M., Tontonoz, P., Castrillo, A., 2009. Apoptotic cells promote their own clearance and immune tolerance through activation of the nuclear receptor LXR. Immunity 31, 245-258.

Alvarez, Y., Municio, C., Alonso, S., Sánchez Crespo, M., Fernández, N., 2009. The induction of IL-10 by fungi in dendritic cells depends on CREB activation by the coactivators CBP and TORC2 and autocrine PGE2. J. Immunol. 183, 1471-1479.

Alvarez, Y., Municio, C., Hugo, E., Zhu, J., Alonso, S., Hu, X., Fernández, N., Sánchez Crespo, M., 2011. Notch and transducin-like enhancer of split (TLE)-dependent histone deacetylation explain IL-12 p70 inhibition by zymosan. J. Biol. Chem. 286, 16583-16595.

Amarilyo, G., Verbovetski, I., Atallah, M., Grau, A., Wiser, G., Gil, O., Ben-Neriah, Y., Mevorach, D., 2010. iC3b-opsonized apoptotic cells mediate a distinct antiinflammatory response and transcriptional NF-кB-dependent blockade. Eur. J. Immunol. 40, 699-709.

Ananieva, O., Darragh, J., Johansen, C., Carr, J.M., McIlrath, J., Park, J.M., Wingate, A., Monk, C.E., Toth, R., Santos, S.G., Iversen, L., Arthur, J.S., 2008. The kinases MSK1 and MSK2 act as negative regulators of Toll-like receptor signaling. Nat. Immunol. 9, 1028-1036.

Anderson, H.A., Maylock, C.A., Williams, J.A., Paweletz, C.P., Shu, H., Shacter, E., 2003. Serum-derived protein $S$ binds to phosphatidylserine and stimulates the phagocytosis of apoptotic cells. Nat. Immunol. 4, 87-91.

Behrens, E.M., Ning, Y., Muvarak, N., Zoltick, P.W., Flake, A.W., Gallucci, S., 2008. Apoptotic cell-mediated immunoregulation of dendritic cells does not require iC3b opsonization. J. Immunol. 181, 3018-3026.

Behrens, E.M., Sriram, U., Shivers, D.K., Gallucci, M., Ma, Z., Finkel, T.H., Gallucci, S., 2007. Complement receptor 3 ligation of dendritic cells suppresses their stimulatory capacity. J. Immunol. 178, 6268-6279.

Bonnefoy, F., Couturier, M., Clauzon, A., Rémy-Martin, J.P., Gaugler, B., Tiberghien, P., Chen, W., Saas, P., Perruche, S., 2011. TGF- $\beta$-exposed plasmacytoid dendritic cells participate in Th17 commitment. J. Immunol. 186, 6157-6164.

Bozza, P.T., Magalhães, K.G., Weller, P.F., 2009. Leukocyte lipid bodies-biogenesis and functions in inflammation. Biochim. Biophys. Acta 1791, 540-551.

Brown, G.D., Herre, J., Williams, D.L., Willment, J.A., Marshall, A.S., Gordon, S., 2003. Dectin-1 mediates the biological effects of $\beta$-glucans. J. Exp. Med. 197, 1119-1124.

Chen, M., Divangahi, M., Gan, H., Shin, D.S., Hong, S., Lee, D.M., Serhan, C.N., Behar, S.M., Remold, H.G., 2008. Lipid mediators in innate immunity against tuberculosis: opposing roles of $\mathrm{PGE}_{2}$ and $\mathrm{LXA}_{4}$ in the induction of macrophage death. J. Exp. Med. 205, 2791-2801.

Chung, S., Gumienny, T.L., Hengartner, M.O., Driscoll, M., 2000. A common set of engulfment genes mediates removal of both apoptotic and necrotic cell corpses in C. elegans. Nat. Cell Biol. 2, 931-937.

Chung, E.Y., Liu, J., Homma, Y., Zhang, Y., Brendolan, A., Saggese, M., Han, J., Silverstein, R., Selleri, L., Ma, X., 2007. Interleukin-10 expression in macrophages during phagocytosis of apoptotic cells is mediated by homeodomain proteins Pbx1 and Prep-1. Immunity 27, 952-964.

Cunha, C., Di Ianni, M., Bozza, S., Giovannini, G., Zagarella, S., Zelante, T., D’Angelo, C., Pierini, A., Pitzurra, L., Falzetti, F., Carotti, A., Perruccio, K., Latgé, J.P., Rodrigues, F., Velardi, A., Aversa, F., Romani, L., Carvalho, A., 2010. Dectin-1 Y238X polymorphism associates with susceptibility to invasive aspergillosis in hematopoietic transplantation through impairment of both recipient- and donor-dependent mechanisms of antifungal immunity. Blood 116, 5394-5402.

de Assis, E.F., Silva, A.R., Caiado, L.F., Marathe, G.K., Zimmerman, G.A., Prescott, S.M., McIntyre, T.M., Bozza, P.T., de Castro-Faria-Neto, H.C., 2003. Synergism between platelet-activating factor-like phospholipids and peroxisome proliferatoractivated receptor- $\gamma$ agonists generated during low density lipoprotein oxidation that induces lipid body formation in leukocytes. J. Immunol. 171, 2090-2098.

Dennehy, K.M., Willment, J.A., Williams, D.L., Brown, G.D., 2009. Reciprocal regulation of IL-23 and IL-12 following co-activation of Dectin-1 and TLR signaling pathways. Eur. J. Immunol. 39, 1379-1386.

Dillon, S., Agrawal, S., Banerjee, K., Letterio, J., Denning, T.L., Oswald-Richter, K., Kasprowicz, D.J., Kellar, K., Pare, J., van Dyke, T., Ziegler, S., Unutmaz, D., Pulendran, B., 2006. Yeast zymosan, a stimulus for TLR2 and dectin-1, induces regulatory antigen-presenting cells and immunological tolerance. J. Clin. Invest. 116, 916-928.

Elliott, M.R., Ravichandran, K.S., 2010. Clearance of apoptotic cells: implications in health and disease. J. Cell Biol. 189, 1059-1070.

Fadok, V.A., Bratton, D.L., Konowal, A., Freed, P.W., Westcott, J.Y., Henson, P.M., 1998. Macrophages that have ingested apoptotic cells in vitro inhibit proinflammatory cytokine production through autocrine/paracrine mechanisms involving TGF- $\beta$, $\mathrm{PGE}_{2}$, and PAF. J. Clin. Invest. 101, 890-898.
Fernández, N., Renedo, M., Alonso, S., Sánchez Crespo, M., 2003. Release of arachidonic acid by stimulation of opsonic receptors in human monocytes: the Fc $\gamma \mathrm{R}$ and the complement receptor 3 pathways. J. Biol. Chem. 278, 52179-52187.

Ferwerda, B., Ferwerda, G., Plantinga, T.S., Willment, J.A., van Spriel, A.B., Venselaar, H., Elbers, C.C., Johnson, M.D., Cambi, A., Huysamen, C., Jacobs, L., Jansen, T., Verheijen, K., Masthoff, L., Morré, S.A., Vriend, G., Williams, D.L., Perfect, J.R., Joosten, L.A., Wijmenga, C., van der Meer, J.W., Adema, G.J., Kullberg, B.J., Brown, G.D., Netea, M.G., 2009. Human dectin-1 deficiency and mucocutaneous fungal infections. N. Engl. J. Med. 361, 1760-1767.

Gerosa, F., Baldani-Guerra, B., Lyakh, L.A., Batoni, G., Esin, S., Winkler-Pickett, R.T., Consolaro, M.R., De Marchi, M., Giachino, D., Robbiano, A., Astegiano, M., Sambataro, A., Kastelein, R.A., Carra, G., Trinchieri, G., 2008. Differential regulation of interleukin 12 and interleukin 23 production in human dendritic cells. J. Exp. Med. 205, 1447-1461.

Gantner, B.N., Simmons, R.M., Canavera, S.J., Akira, S., Underhill, D.M., 2003. Collaborative induction of inflammatory responses by dectin-1 and Toll-like receptor 2. J. Exp. Med. 197, 1107-1117.

Gautier, G., Humbert, M., Deauvieau, F., Scuiller, M., Hiscott, J., Bates, E.E., Trinchieri, G., Caux, C., Garrone, P., 2005. A type I interferon autocrine-paracrine loop is involved in Toll-like receptor-induced interleukin-12 p70 secretion by dendritic cells. J. Exp. Med. 201, 1435-1446.

Goh, S.L., Looi, Y., Shen, H., Fang, J., Bodner, C., Houle, M., Ng, A., Screaton, R.A., Featherstone, M., 2009. Transcriptional activation by MEIS1A in response to protein kinase A signaling requires the transducers of regulated CREB family of CREB co-activators. J. Biol. Chem. 284, 18904-18912.

Goodall, J.C., Wu, C., Zhang, Y., McNeill, L., Ellis, L., Saudek, V., Gaston, J.S., 2010. Endoplasmic reticulum stress-induced transcription factor, CHOP, is crucial for dendritic cell IL-23 expression. Proc. Natl. Acad. Sci. U. S. A. 107, 1769817703.

Hanayama, R., Tanaka, M., Miwa, K., Shinohara, A., Iwamatsu, A., Nagata, S., 2002. Identification of a factor that links apoptotic cells to phagocytes. Nature 417, 182-187.

Harizi, H., Juzan, M., Pitard, V., Moreau, J.F., Gualde, N., 2002. Cyclooxygenase-2issued prostaglandin $E_{2}$ enhances the production of endogenous IL-10, which down-regulates dendritic cell functions. J. Immunol. 168, 2255-2263.

Hu, X., Paik, P.K., Chen, J., Yarilina, A., Kockeritz, L., Lu, T.T., Woodgett, J.R., Ivashkiv, L.B., 2006. IFN- $\gamma$ suppresses IL-10 production and synergizes with TLR2 by regulating GSK3 and CREB/AP-1 proteins. Immunity 24, 563-574.

Huang, H., Ostroff, G.R., Lee, C.K., Wang, J.P., Specht, C.A., Levitz, S.M., 2009. Distinct patterns of dendritic cell cytokine release stimulated by fungal $\beta$-glucans and toll-like receptor agonists. Infect. Immun. 77, 1774-1781.

Huang, J.T., Welch, J.S., Ricote, M., Binder, C.J., Willson, T.M., Kelly, C., Witztum, J.L., Funk, C.D., Conrad, D., Glass, C.K., 1999. Interleukin-4-dependent production of PPAR- $\gamma$ ligands in macrophages by $12 / 15$-lipoxygenase. Nature 400,378 382.

Jansson, D., Ng, A.C., Fu, A., Depatie, C., Al Azzabi, M., Screaton, R.A., 2008. Glucose controls CREB activity in islet cells via regulated phosphorylation of TORC2. Proc. Natl. Acad. Sci. U. S. A. 105, 10161-10166.

Jennewein, C., Kuhn, A.M., Schmidt, M.V., Meilladec-Jullig, V., von Knethen, A., Gonzalez, F.J., Brüne, B., 2008. Sumoylation of peroxisome proliferatoractivated receptor- $\gamma$ by apoptotic cells prevents lipopolysaccharide-induced NCoR removal from $\kappa \mathrm{B}$ binding sites mediating transrepression of proinflammatory cytokines. J. Immunol. 181, 5646-5652.

Johansson, U., Walther-Jallow, L., Hofmann, A., Spetz, A.L., 2010. Dendritic cells are able to produce IL-12p70 after uptake of apoptotic cells. Immunobiology 216, 251-255.

Kelly, E.K., Wang, L., Ivashkiv, L.B., 2010. Calcium-activated pathways and oxidative burst mediate zymosan-induced signaling and IL-10 production in human macrophages. J. Immunol. 184, 5545-5552.

Kim, S., Elkon, K.B., Ma, X., 2004. Transcriptional suppression of interleukin-12 gene expression following phagocytosis of apoptotic cells. Immunity 21, 643-653.

Kovács, K.A., Steullet, P., Steinmann, M., Do, K.Q., Magistretti, P.J., Halfon, O., Cardinaux, J.R., 2007. TORC1 is a calcium- and cAMP-sensitive coincidence detector involved in hippocampal long-term synaptic plasticity. Proc. Natl. Acad. Sci. U. S. A. $104,4700-4705$.

Leibundgut-Landmann, S., Gross, O., Robinson, M.J., Osorio, F., Slack, E.C., Tsoni, S.V., Schweighoffer, E., Tybulewicz, V., Brown, G.D., Ruland, J., Reis e Sousa, C., 2007. Syk- and CARD9-dependent coupling of innate immunity to the induction of T helper cells that produce interleukin 17. Nat. Immunol. 8, 630-638.

Liu, Y., Dentin, R., Chen, D., Hedrick, S., Ravnskjaer, K., Schenk, S., Milne, J., Meyers, D.J., Cole, P., Yates 3rd, J., Olefsky, J., Guarente, L., Montminy, M., 2008. A fasting inducible switch modulates gluconeogenesis via activator/coactivator exchange. Nature 456, 269-273.

Martin, M., Rehani, K., Jope, R.S., Michalek, S., 2005. Toll-like receptor-mediated cytokine production is differentially regulated by glycogen synthase kinase 3 . Nat. Immunol. 6, 777-784.

Mattos, K.A., D’Avila, H., Rodrigues, L.S., Oliveira, V.G., Sarno, E.N., Atella, G.C., Pereira, G.M., Bozza, P.T., Pessolani, M.C., 2010. Lipid droplet formation in leprosy: Toll-like receptor-regulated organelles involved in eicosanoid formation and Mycobacterium leprae pathogenesis. J. Leukoc. Biol. 87, 371-384.

Mbonye, U.R., Yuan, C., Harris, C.E., Sidhu, R.S., Song, I., Arakawa, T., Smith, W.L., 2008. Two distinct pathways for cyclooxygenase-2 protein degradation. J. Biol. Chem. 283, 8611-8623.

Means, T.K., Mylonakis, E., Tampakakis, E., Colvin, R.A., Seung, E., Puckett, L., Tai, M.F., Stewart, C.R., Pukkila-Worley, R., Hickman, S.E., Moore, K.J., Calderwood, S.B., Hacohen, N., Luster, A.D., El Khoury, J., 2009. Evolutionarily conserved recog- 
106

C. Municio et al. / Molecular Immunology 49 (2011) 97-106

nition and innate immunity to fungal pathogens by the scavenger receptors SCARF1 and CD36. J. Exp. Med. 206, 637-653.

Medeiros, A.I., Serezani, C.H., Lee, S.P., Peters-Golden, M., 2009. Efferocytosis impairs pulmonary macrophage and lung antibacterial function via $\mathrm{PGE}_{2} / \mathrm{EP} 2$ signaling. J. Exp. Med. 206, 61-68.

Mellett, M., Atzei, P., Jackson, R., O’Neill, L.A., Moynagh, P.N., 2011. Mal mediates TLRinduced activation of CREB and expression of IL-10. J. Immunol. 186, 4925-4935.

Morris, E.J., Geller, H.M., 1996. Induction of neuronal apoptosis by camptothecin, an inhibitor of DNA topoisomerase-I: evidence for cell cycle-independent toxicity. J. Cell Biol. 134, 757-770.

Mukundan, L., Odegaard, J.I., Morel, C.R., Heredia, J.E., Mwangi, J.W., RicardoGonzalez, R.R., Goh, Y.P.S., Eagle, A.R., Dunn, S.E., Awakuni, J.U., Nguyen, K.D., Steinman, L., Michie, S.A., Chawla, A., 2009. PPAR- $\delta$ senses and orchestrates clearance of apoptotic cells to promote tolerance. Nat. Med. 15, 1266-1272.

Napolitani, G., Rinaldi, A., Bertoni, F., Sallusto, F., Lanzavecchia, A., 2005. Selected Toll-like receptor agonist combinations synergistically trigger a T helper type 1-polarizing program in dendritic cells. Nat. Immunol. 6, 769-776.

Pacheco, P., Bozza, F.A., Gomes, R.N., Bozza, M., Weller, P.F., Castro-Faria-Neto, H.C., Bozza, P.T., 2002. Lipopolysaccharide-induced leukocyte lipid body formation in vivo: innate immunity elicited intracellular loci involved in eicosanoid metabolism. J. Immunol. 169, 6498-6506.

Platzer, C., Fritsch, E., Elsner, T., Lehmann, M.H., Volk, H.D., Prösch, S., 1999. Cyclic adenosine monophosphate-responsive elements are involved in the transcriptional activation of the human IL-10 gene in monocytic cells. Eur. J. Immunol. 29, 3098-30104.

Sancho, D., Joffre, O.P., Keller, A.M., Rogers, N.C., Martínez, D., Hernanz-Falcón, P., Rosewell, I., Reis e Sousa, C., 2009. Identification of a dendritic cell receptor that couples sensing of necrosis to immunity. Nature 458, 899-903.

Snijders, A., Kalinski, P., Hilkens, C.M., Kapsenberg, M.L., 1998. High-level IL-12 production by human dendritic cells requires two signals. Int. Immunol. 10 , 1593-1598.

Sorgi, C.A., Secatto, A., Fontanari, C., Turato, W.M., Belangér, C., de Medeiros, A.I., Kashima, S., Marleau, S., Covas, D.T., Bozza, P.T., Faccioli, L.H., 2009. Histoplasma capsulatum cell wall $\beta$-glucan induces lipid body formation through CD18, TLR2, and dectin-1 receptors: correlation with leukotriene $\mathrm{B}_{4}$ generation and role in HIV-1 infection. J. Immunol. 182, 4025-4035.
Szatmari, I., Nagy, L., 2008. Nuclear receptor signalling in dendritic cells connects lipids, the genome and immune function. EMBO J. 27, 2353-2362.

Szatmari, I., Töröcsik, D., Agostini, M., Nagy, T., Gurnell, M., Barta, E., Chatterjee, K., Nagy, L., 2007. PPAR- $\gamma$ regulates the function of human dendritic cells primarily by altering lipid metabolism. Blood 110, 3271-3280.

Szanto, A., Balint, L.B., Nagy, Z.S., Barta, E., Dezso, B., Pap, A., Szeles, L., Poliska, S., Oros, M., Evans, R.M., Barak, Y., Schwabe, J., Nagy, L., 2010. STAT6 transcription factor is a facilitator of the nuclear receptor PPAR-regulated gene expression in macrophages and dendritic cells. Immunity 33, 699-712.

Thomas Jr., C.F., Limper, A.H., 2004. Pneumocystis pneumonia. N. Engl. J. Med. 350, 2487-2498.

Tohyama, Y., Yamamura, H., 2009. Protein tyrosine kinase, syk: a key player in phagocytic cells. J. Biochem. 145, 267-273.

Valera, I., Fernández, N., Trinidad, A.G., Alonso, S., Brown, G.D., Alonso, A., Sánchez Crespo, M., 2008. Costimulation of dectin-1 and DC-SIGN triggers the arachidonic acid cascade in human monocyte-derived dendritic cells. J. Immunol. 180, 5727-5736.

Villanueva, C.J., Tontonoz, P., 2010. Licensing PPAR $\gamma$ to work in macrophages. Immunity 33, 647-649.

Vo, N., Goodman, R.H., 2001. CREB-binding protein and p300 in transcriptional regulation. J. Biol. Chem. 276, 13505-13508.

Wang, Z., Iwasaki, M., Ficara, F., Lin, C., Matheny, C., Wong, S.H., Smith, K.S., Cleary, M.L., 2010. GSK-3 promotes conditional association of CREB and its coactivators with MEIS1 to facilitate HOX-mediated transcription and oncogenesis. Cancer Cell 17, 597-608.

Weck, M.M., Appel, S., Werth, D., Sinzger, C., Bringmann, A., Grünebach, F., Brossart, P., 2008. hDectin-1 is involved in uptake and cross-presentation of cellular antigens. Blood 111, 4264-4272.

Willson, T.M., Brown, P.J., Sternbach, D.D., Henke, B.R., 2000. The PPARs: from orphan receptors to drug discovery. J. Med. Chem. 43, 527-550.

Zhou, Z., Hartwieg, E., Horvitz, H.R., 2001. CED-1 is a transmembrane receptor that mediates cell corpse engulfment in C. elegans. Cell 104, 43-56.

Ziegenfuss, J.S., Biswas, R., Avery, M.A., Hong, K., Sheehan, A.E., Yeung, Y.G., Stanley, E.R., Freeman, M.R., 2008. Draper-dependent glial phagocytic activity is mediated by Src and Syk family kinase signalling. Nature 453, 935-939. 